Universidade de São Paulo

Faculdade de Zootecnia e Engenharia de Alimentos

Marcadores moleculares e a caracterização dos recursos genéticos de peixes: desenvolvimento sustentável da aquicultura e da pesca de espécies nativas de água doce no Brasil

ALEXANDRE WAGNER SILVA HILSDORF

Texto sistematizado apresentado a Faculdade de Faculdade de Zootecnia e Engenharia de Alimentos da Universidade de São Paulo, para obtenção do título de professor Livre-Docente, junto ao Departamento de Medicina Veterinária na área de Conservação de Recursos Genéticos Animais.

Pirassununga 
Dados Internacionais de Catalogação na Publicação

Serviço de Biblioteca e Informação da Faculdade de Zootecnia e Engenharia de Alimentos da Universidade de São Paulo

H655m

Hilsdorf, Alexandre Wagner Silva

Marcadores moleculares e a caracterização dos

recursos genéticos de peixes: desenvolvimento

sustentável da aquicultura e da pesca de espécies

nativas de água doce no Brasil / Alexandre Wagner Silva

Hilsdorf. -- Pirassununga, 2013.

$159 \mathrm{f}$.

Tese (Livre Docência) -- Faculdade de Zootecnia e

Engenharia de Alimentos - Universidade de São Paulo.

Departamento de Medicina Veterinária.

Área de Concentração: Conservação de Recursos

Genéticos Animais.

1. Recursos genéticos 2. Peixes 3. Água doce

4. Neotropical 5. Marcadores moleculares 6. Populações

7. Aquicultura. I. Título. 
Dedico

A minha companheira de vída Mônica e minha fitha Bruna pela inspíração e apoio aos meus sonhos e conquistas, e que sempre entenderam do tempo ausente em razão da dedicação ao meu trabalho.

Aos meus pais Orlando Hilsdorf (ín memoriam) e Helena Sílva Hilsdorf (ín memoriam) sem a inspiração deles $\sigma$ inicio desta jornada teria sido impossivel. 


\section{AGRADECIMENTOS}

À Universidade de Mogi das Cruzes que tem me dado todo apoio desde minha contratação aos trabalhos de pesquisa que desenvolvo no Laboratório de Genética de Organismos Aquáticos e Aquicultura (LAGOAA) do Núcleo Integrado de Biotecnologia.

Às agências de financiamento à pesquisa, CNPq, CAPES e principalmente a FAPESP pelo apoio financeiro direto aos trabalhos que venho coordenando nestes anos e as bolsas fornecidas aos meus alunos.

Aos professores que contribuíram na minha formação acadêmica e científica; minha primeira orientadora na graduação em Zootecnia no departamento de Biologia na ESAL (UFLA) Dra. Lisete Chamma David, aos meus orientadores de mestrado Dr. Brendan McAndrew e Dr. David Penman do Instituto de Aquicultura da Universidade de Stirling/Escócia e meus orientadores de doutorado Dr. José Eduardo Krieger e Dra. Marta Helena Krieger do Instituto do Coração e da Universidade Estadual de Campinas, respectivamente.

Aos meus colaboradores de diversas instituições que ao longo destes anos tem me ajudado em vários de meus projetos. São diversos, ao nomeá-los poderia incorrer na injustiça de esquecer alguém. Em especial ao Prof. Dr. José Bento Sterman Ferraz que me incentivou e apoiou a ideia de escrever esta tese de livre docência.

Por fim, mas não menos importante, os atores principais nesta trajetória, todos os meus queridos alunos passados e atuais desde a Iniciação Científica, Mestrado e Doutorado que foram os responsáveis diretos pela realização de todas as ideias pensadas em discussões científicas e realizadas na bancada do laboratório, sem eles eu não teria chegado até este momento. 


\section{RESUMO}

A produção de alimentos no mundo é hoje um desafio a ser alcançado face ao crescimento populacional, mudanças climáticas e cada vez menos recursos naturais disponíveis. A proteína de origem animal oriunda dos recursos pesqueiros é hoje uma importante fonte de alimento para diversas populações ao redor do mundo. A utilização de peixes para alimentação humana é baseada tanto no extrativismo como na domesticação de espécies para criação em cativeiro, a chamada piscicultura, e a contribuição do pescado é hoje significativa no total da produção de alimentos no planeta. A região neotropical abriga a maior diversidade de espécies de peixes entre todos os ecossistemas de águas continentais. Muitas destas espécies são diretamente utilizadas pela pesca, seja ela a pesca industrial, extrativista ou esportiva, cujas atividades geram além de alimentos emprego e renda as comunidades ribeirinhas. Também, a piscicultura é uma atividade produtiva que utiliza espécies de peixes nativas ou não para produção de pescado em sistemas zootécnicos mais controlados. Atualmente, o conhecimento e conservação dos recursos genéticos são etapas fundamentais para que os estoques pesqueiros possam continuar a ser utilizados de forma sustentável. Os recursos genéticos podem ser entendidos, não somente pela diversidade de espécies, mas também pelas diferenças encontradas entre populações de espécies ou mesmos raças e variedades em animais e plantas domesticadas, respectivamente. $\mathrm{O}$ uso de marcadores genéticos vem desde a década de 1970 evidenciando a variabilidade dentro e entre populações de forma a entender os processos que levam ao isolamento e adaptação de populações locais. Esta abordagem é de pivotal importância para que tais populações e suas particularidades adaptativas possam ser mantidas e de certa forma utilizada em programas de melhoramento genético de espécies domesticadas ou em processo de domesticação. O presente estudo objetivou sistematizar e discutir os resultados publicados de estudos genéticos populacional com peixes de água docena região neotropical. Um levantamento de dados a partir de bancos de dados como ISI Web of Science e ASFA (Aquatic Science and Fisheries Abstract) foi feito e todos os estudos com marcadores protéicos, e aqueles baseados no polimorfismo do DNA foram revisados e descritos quanto aos índices de diversidade genética gerados. Os resultados de tais índices foram comparados entre si e com trabalhos similares produzidos com peixes do hemisfério norte para se verificar padrões de distribuição da diversidade genética. As considerações finais do presente estudo são apresentadas de maneira a contribuir com um melhor encaminhamento de futuros estudos na área de genética de populações de peixes de água doce.

Palavras-chave: Recursos Genéticos;Peixes; Água doce; Neotropical; Marcadores moleculares; Populações; Aquicultura; Pesca. 


\begin{abstract}
Food production in the world today is a challenge to be pursued in view of the population growth, climate changes and increasing decline of natural resources availability. The animal protein derived from fish resources is now an important source of food for several populations around the world. The use of fish for human consumption is based on either the extraction or on the domestication of species for captive breeding, also known as aquaculture, and, nowadays, the contribution of fish is substantial to the overall food production on the planet. The Neotropical region harbors the greatest diversity of fish species among all inland water ecosystems. Many of these species are directly used for fishing, be it industrial, extractive or sports fishing, which are activities that generate jobs in addition to food and income for riverine populations. Furthermore, fish farming is a productive activity that uses native or non-native fish species for fish production within more controlled production systems. Currently, the knowledge and conservation of genetic resources are key stages that ensure the sustainable use of fish stocks. The genetic resources can be understood, not only in relation to the diversity of species but also to the differences between populations of the same species or even breeds and varieties in domesticated animals and plants, respectively. The use of genetic markers goes back to the 1970s, evidencing the variability within and among populations aiming to understand the processes that lead to the isolation and adaptation of local populations. This approach is of pivotal significance so that such populations and their adaptive particularities can be maintained and somehow used in breeding programs of domesticated species or in the process of domestication. The present study was undertaken with the intention to systematize and discuss the published results of population genetic studies of freshwater fish in the Neotropical region. An assessment of databases, such as ISI Web of Science and ASFA (Aquatic Science and Fisheries Abstract), was conducted and all studies with protein markers, as well as those based on DNA polymorphism, were reviewed and described according to the indices of genetic diversity generated. The results of these indices were compared among themselves and with similar works previously accomplished with fish from the northern hemisphere to verify the distribution patterns of genetic diversity. The final considerations of this study are presented so as to contribute to better approaches of future studies on the population genetics of freshwater fish.
\end{abstract}

Key words: Genetic resources; Fish; Freshwater; Neotropical; Molecular Markers; Population; Aquaculture; Fisheries. 


\section{LISTA DE FIGURAS}

\begin{tabular}{|c|c|c|}
\hline Figura 1 & Estimativa da produção das principais culturas vegetais & 16 \\
\hline Figura 2 & $\begin{array}{l}\text { Proporção das raças do mundo de todas as espécies em criação } \\
\text { por categoria de risco de extinção }\end{array}$ & 24 \\
\hline Figura 3 & Produção pesqueira de águas continentais de 1950 a 2009 & 27 \\
\hline Figura 4 & Captura mundial de peixe de água doce & 28 \\
\hline Figura 5 & $\begin{array}{l}\text { Quantidades de peixes capturados pela pesca em águas continentais nos } \\
\text { últimos cinco anos }\end{array}$ & 30 \\
\hline Figura 6 & Produção de peixe em cativeiro no Brasil de 2003 a 2010 & 31 \\
\hline Figura 7 & Modelo básico da genética de populações & 35 \\
\hline Figura 8 & Modelo simples de diferenciação contínua de populações & 37 \\
\hline Figura 9 & Modelo de Continente-Ilha & 38 \\
\hline Figura 10 & Modelo de Ilhas Simétricas & 38 \\
\hline Figura 11 & Modelo passo-a-passo linear & 38 \\
\hline Figura 12 & Modelo passo-a-passo bi-dimensional & 38 \\
\hline Figura 13 & $\begin{array}{l}\text { Representação dos fatores que afetam o conceito de "Estoque" para o } \\
\text { manejo pesqueiro }\end{array}$ & 40 \\
\hline Figura 14 & $\begin{array}{l}\text { Produção de trabalhos sobre o desenvolvimento de lócus STR de } \\
\text { espécies de peixes de água doce neotropicais }\end{array}$ & 103 \\
\hline
\end{tabular}




\section{LISTA DE TABELAS}

\begin{tabular}{|c|c|c|}
\hline Tabela 1 & Conceituações dos termos: Recursos Biológicos e Recursos Genéticos & $19-20$ \\
\hline Tabela 2 & $\begin{array}{l}\text { Lista de Acrônimos dos principais marcadores moleculares usados } \\
\text { em estudos genéticos. }\end{array}$ & 47 \\
\hline Tabela 3 & $\begin{array}{l}\text { Tipos de marcadores moleculares, suas características e aplicação na } \\
\text { avaliação genética de populações de peixes. }\end{array}$ & 49 \\
\hline Tabela 4 & Níveis de hierarquização e a estatística- $\Phi$ derivada & 56 \\
\hline Tabela 5 & $\begin{array}{l}\text { Valores médios dos parâmetros genéticos avaliados por proteínas em } \\
\text { estudos populacionais de pexies neotropicais. }\end{array}$ & 67 \\
\hline Tabela 6 & $\begin{array}{l}\text { Resumo comparativo dos índices médios de variabilidade genética } \\
\text { e de diferenciação populacional entre os estudos citados. }\end{array}$ & 68 \\
\hline Tabela 7 & $\begin{array}{l}\text { Resumo dos trabalhos genético populacional de peixes neotropicais com } \\
\text { o uso do DNAmt. }\end{array}$ & $79-80$ \\
\hline Tabela 8 & Categorias para interpretação de $(h)$ e $(\pi)$ & 82 \\
\hline Tabela 9 & $\begin{array}{l}\text { Resumo dos trabalhos publicados com peixes neotropicais com o } \\
\text { marcador RAPD. }\end{array}$ & $84-87$ \\
\hline Tabela 10 & $\begin{array}{l}\text { Relação de estudos publicados sobre o desenvolvimento de lócus } \\
\text { STR. }\end{array}$ & $92-93$ \\
\hline Tabela 11 & $\begin{array}{l}\text { Valores de parâmetros utilizados nos estudos genéticos populacionais de } \\
\text { peixes de água doce neotropical. }\end{array}$ & 105 \\
\hline Tabela 12 & $\begin{array}{l}\text { Valores de diferenciação populacional ajustada de acordo com } \\
\text { Hedrick (2005). }\end{array}$ & 106 \\
\hline Tabela 13 & Variação genética de lócus STR em peixes de água doce e outros animais. & 108 \\
\hline
\end{tabular}




\begin{abstract}
APRESENTAÇÃO
Este texto sistematizado foi organizado na forma de capítulos para desenvolver as questões que envolvem os recursos genéticos animais. $O$ capítulo 1 introduz o leitor a conceituação terminológica e teórica que cercam o tema em questão e revisa o estado-de-arte da situação dos recursos pesqueiros e aquícolas de água doce no Brasil. Em seguida no capítulo 2 procurou-se rever o arcabouço teórico dos conceitos de populações dentro do contexto da conservação e utilização dos recursos genéticos e descrever os caminhos de desenvolvimento dos índices de mensuração da diversidade genética intra e interpopulacional. No capítulo 3, uma revisão dos artigos publicados sobre estudos genéticos populacionais de peixes de água doce na região neotropical com o uso de marcadores moleculares seguido de uma discussão para cada um dos marcadores foi realizada. No capítulo 4, nas considerações finais procurou-se sistematizar os resultados do conjunto de trabalhos publicados.

Neste contexto, inclui os artigos de minha autoria e orientação que são representativos desta linha de pesquisa que são inicialmente oriundos de meu doutoramento e depois das diferentes orientações de mestrado e doutoramento realizados no Laboratório de Genética de Organismos Aquáticos e Aquicultura (LAGOAA) do Núcleo integrado de Biotecnologia da Universidade de Mogi das Cruzes desde 2000.

Os artigos e dissertações incluídos estão na seguinte ordem:
\end{abstract}

\title{
Artigo 1-
}

HILSDORF, A. W. S.; KRIEGER, J. E. Characterization of six rat strains (Rattus norvegicus) by mitochondrial DNA restriction fragment length polymorphism (RFLP). Brazilian Journal of Medical and Biological Research, v. 32, p. 267-273, 1999.

\section{ARTigo 2-}

HILSDORF, A. W. S.; ESPIN, A. M. L. A.; KRIEGER, M. H.; KRIEGER, J. E. Mitochondrial DNA diversity in wild and captivity population of Brycon opalinus (Cuvier, 1819) (Characiforme, Characidae, Bryconiae), in the Paraíba do Sul Basin, Brazil. Aquaculture, v. 214, p. $81-91,2002$.

\section{ARTigo 3-}

HILSDORF, A. W. S.; CANEPPELE, D.; KRIEGER, J. E. Muscle biopsy technique for electrophoresis analysis of fish from the genus Brycon. Genetics and Molecular Biology, v. 22, p. 547-550, 1999. 


\section{Artigo 4-}

IERVOLINO, F.; RESENDE, E. K.; HILSDORF, A. W. S. 2010. The lack of genetic differentiation of pacu (Piaractus mesopotamicus) populations in the Upper-Paraguay Basin revealed by the mitochondrial DNA D-loop region: Implications for fishery management. Fisheries Research, v. 101, p. 27-31, 2010.

\section{Artigo 5-}

BARROSO, R. M.; HILSDORF, A. W. S.; MOREIRA, H. L. M.; MELLO, A. M.; GUIMARÃES, S. E. F.; CABELLO, P. H.; TRAUB-CSEKO, Y. M. Identification and characterization of microsatellites loci in Brycon opalinus (Cuvier, 1819) (Characiforme, Characidae, Bryconiae). Molecular Ecology Notes, v. 3, p. 297-298, 2003.

\section{Artigo 6-}

SILVA, J. V.; HILSDORF, A. W. S. Isolation and characterization of polymorphic microsatellite loci from Salminus bilarii (Characiformes: Characidae). Conservation Genetic Resources, v. 3, p 437-439, 2011.

\section{Artigo 7-}

BARROSO, R. M.; HILSDORF, A. W. S.; MOREIRA, H. L. M.; CABELLO, P. H.; TRAUBCSEKO, Y. M. Genetic diversity of wild and cultured populations of Brycon opalinus (Cuvier, 1819) (Characiforme, Characidae, Bryconiae) using microsatellites. Aquaculture, v. 247, p. $51-65,2005$.

\section{Artigo 8-}

MATSUMOTO, C. K.; HILSDORF, A. W. S. Microsatellite variation and population genetic structure of a Neotropical endangered Bryconinae species Brycon insignis Steindachner, 1877: implications for its conservation and sustainable management. Neotropical Ichthyology, v. 7, p. 395-402, 2009.

\section{Dissertação 1-}

OKAZAKI, T. I. Avaliação da diversidade genética intra e interpopulacional da piraputanga (Brycon hilarii) na bacia do alto paraguai por meio de microssatélites para o seu manejo sustentado. 2009. 92 f. Dissertação de Mestrado, Universidade de Mogi das Cruzes, 2009. 


\section{Dissertação 2-}

SILVA, J. V. Caracterização da diversidade genética da tabarana, Salminus hilarii (Valenciennes, 1849) (Characiformes: Characidae) da bacia do alto paraná por marcadores microssatélites. 2009. 114 f., Dissertação de Mestrado, Universidade de Mogi das Cruzes.

\section{Dissertação 3-}

VILAR, J. A. Avaliação genética populacional do Surubim-do-Paraíba (Steindachneridion parahybae, Siluriformes, Pimelodidae) na bacia do Paraíba do Sul por meio de marcadores microssatélites e DNA mitocondrial. 2012. 111 f. Dissertação de Mestrado, Universidade de Mogi das Cruzes, 2012. 


\section{SUMÁRIO}

\section{Capítulo I}

O que são recursos genéticos e sua importância para produção de alimentos

\begin{tabular}{lll}
\hline 1.1. & Sobre a diversidade biológica & 15 \\
\hline 1.2. & O que são recursos biológicos, recursos genéticos, patrimônio genético & 18 \\
\hline 1.3. & A importância dos recursos genéticos e a produção de alimentos & 20 \\
\hline 1.4. & Os recursos genéticos animal & 23 \\
\hline 1.5. & Sobre os recursos genéticos de peixes de água doce no mundo & 25 \\
\hline 1.6. & Sobre os recursos genéticos de peixes nativos de água doce no Brasil \\
\hline & & 29 \\
\hline Capítulo II & 34 \\
\hline Caracterização dos recursos genéticos & 39 \\
\hline 2.1. & Entendendo a estrutura genética de populações & 41 \\
\hline 2.2. & O conceito de populações para o manejo de espécie sob explotação \\
\hline 2.3. & Variação genética e sua importância para a domesticação e melhoramento de & \\
\hline & peixes & 45 \\
\hline 2.4. & Os marcadores moleculares usados na caracterização de populações de peixes & 41 \\
\hline 2.5. & Parâmetros de variabilidade genética intra e interpopulacional & 50 \\
\hline 2.5.1. & Quantificação da diversidade genética intrapopulacional & 51 \\
\hline 2.5.2. & Quantificação da diversidade genética interpopulacional & 52 \\
\hline
\end{tabular}

\section{Capítulo III}

Recursos genéticos populacionais de peixes de água doce da região Neotropical

3.1. Sobre a biogeografia da região Neotropical

3.2. Evolução dos estudos de genética populacional baseado em marcadores em 61 peixes neotropicais

3.2.1. Marcadores protéicos

3.2.1.1. Discussão sobre marcadores protéicos

3.2.2 Marcadores baseados no DNA mitocondrial

3.2.2.2. Avaliação populacional por comparação de sequências do DNAmt

3.2.2.3. Discussão sobre marcadores baseados no DNA mitocondrial 78

3.2.3. RAPD 
3.2.3.1. Discussão sobre RAPD

3.2.4. Microssatélites (STR)

3.2.4.1 Discussão sobre STR

Capítulo IV

Considerações finais

4.1 Considerações finais 
To adopt the ethic for living sustainably, people must re-examine their values and altertheir behavior." IUCN, Caring for the Earth, 1991 


\section{Capítulo I - O que são recursos genéticos e sua importância para produção de alimentos}

\subsection{Sobre a diversidade biológica}

A diversidade biológica presente no planeta terra é o resultado de um processo dinâmico que se iniciou há aproximadamente 4,5 bilhões de anos. Estratos de sedimentos formados em regiões de costeiras, conhecidos como estromatólitos (stromatolites), nos quais são encontrados biofilmes de microorganismos, especialmente Cianobactérias, bactérias ainda presentes nos dias atuais, provavelmente tenham sido as primeiras formas de vida mais organizadas há 3,4 bilhões de anos (LOWE, 1980). Independente das diferentes teorias para o surgimento da vida no planeta terra, a vida como conhecemos, baseada em uma molécula para armazenamento de informações biológicas - RNA no princípio e então DNA (ORGEL, 1994), encontrou na Terra as condições perfeitas para sua diversificação e expansão, um planeta com condições climáticas relativamente estáveis com abundância de água.

De acordo com o Dr. David W. Deamer, bioquímico do Depto. de Química da Universidade da Califórnia “A vida pode ter várias origens. Nós geralmente utilizamos origens no plural apenas para indicar que nós necessariamente não afirmamos que exista uma origem única, que seja apenas uma origem que não tenha ocorrido pelo impacto de um ou mais asteroides gigantes".

A diversidade biológica, a Biodiversidade, refere-se hoje a "variedade de espécies e ecossistemas e os processos ecológicos dos quais fazem parte e que compreende três componentes: diversidade de espécies e de ecossistemas", ou mesmo, "a variedade de vida na terra em todos os seus níveis, de genes a ecossistemas, e os processos ecológicos e evolucionários que a mantém”. (GASTON, 1996). De acordo com a proposta da Convenção sobre Diversidade Biológica (CBD, 92): "Diversidade biológica significa a variabilidade de organismos vivos de todas as origens, compreendendo, dentre outros, os ecossistemas terrestres, marinhos e outros ecossistemas aquáticos e os complexos ecológicos de que fazem parte; compreendendo ainda a diversidade dentro de espécies, entre espécies e de ecossistemas".

As transições climáticas experimentadas pela Terra na transição de um mundo glacial para interglacial fizeram da natureza o único agente de mudanças para os processos evolutivos das espécies neste planeta. Com a passagem do homem caçador/coletor para o estabelecimento dos primeiros modos de produção agrícola e de domesticação animal há cerca de 10.000 anos (SAUER, 1952; HIGGS; JARMAN, 1969), o homem sozinho passa a ter papel fundamental nas mudanças ambientais que viriam de forma gradual a impactar a diversidade biológica na Terra. A 
Revolução Industrial foi um marco na passagem do modo de produção feudal para um sistema de produção que tem nos recursos naturais sua base de exploração. Neste período inicia-se um declínio do número de espécies e a extinção de muitas outras (VITOUSEK et al., 1997).

O homem caçador/coletor tinha como base de sua alimentação uma ampla variedade de alimentos vegetais e animais. Com o início da agricultura e da domesticação animal, houve uma tendência de se concentrar em algumas poucas espécies vegetais e animais que fossem mais produtivas no caso vegetal, e de fácil domesticação no caso animal. Isto fez com que a base alimentar da espécie humana ficasse concentrada em não mais do que 26 culturas agrícolas, sendo que quatro delas - trigo, arroz, milho e batata - contribuem com mais produção que todas as outras culturas juntas, inclusive estão diretamente associadas à produção de carne na pecuária (HARLAN, 1992) (Figura 1).

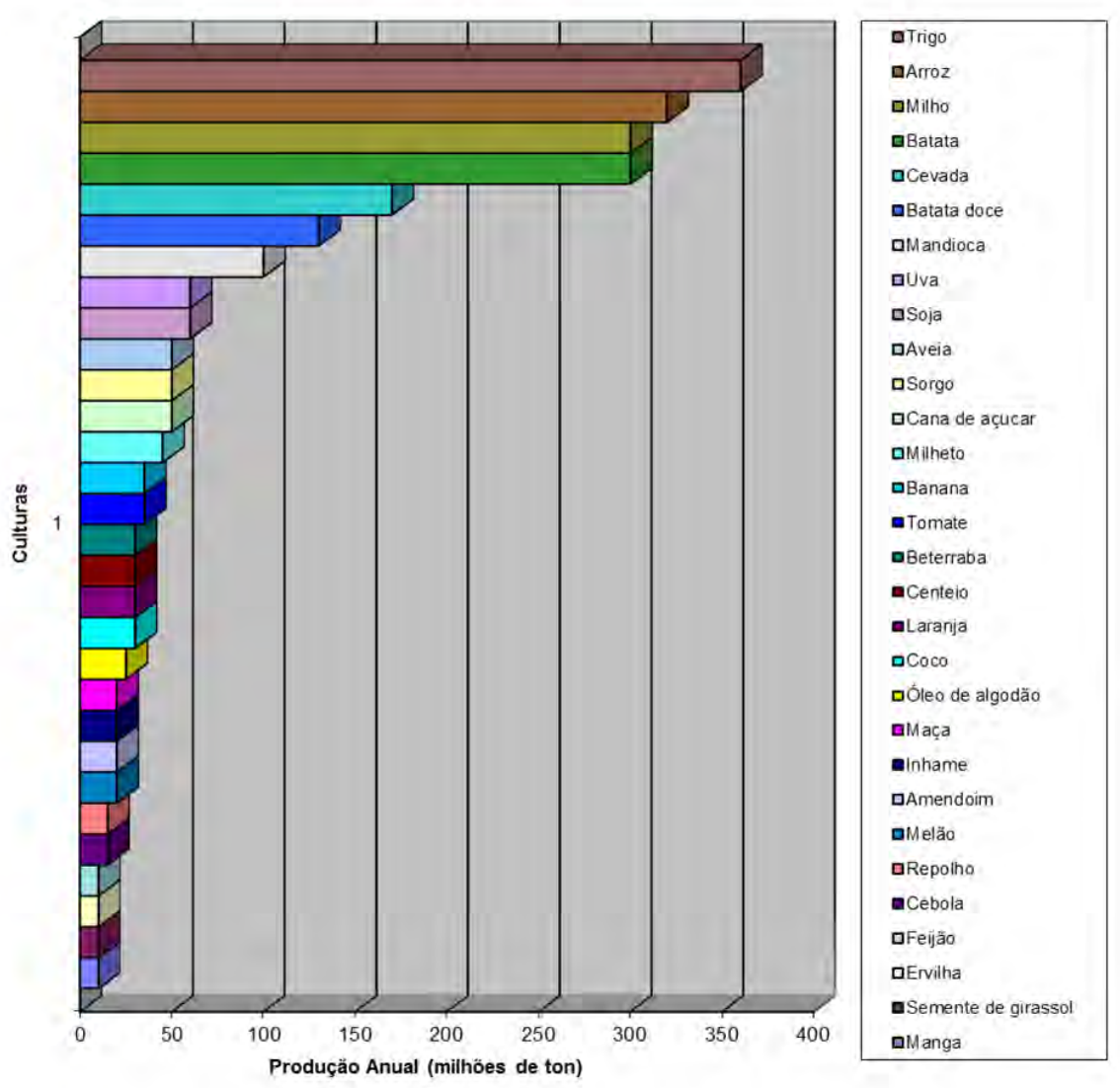

Figura 1. Estimativa da produção das principais culturas vegetais (adaptado de HARLAN, 1976). 
O estabelecimento dos centros de origem das principais culturas vegetais cultivadas pelo homem foi creditado aos estudos liderados pelo geneticista russo Nikolai Ivanovich Vavilov (1887-1943). Vavilov em suas viagens na primeira metade do século XX visitou os cinco continentes de onde coletou sementes silvestres de plantas cultivadas e as armazenou em coleções no Instituto de Investigações Científicas de Leningrado atual São Petersburgo na antiga URSS, o qual foi diretor de 1916 a 1936. Sua principal obra - Origin and Geography of Cultivated Plants originalmente foi publicada em 1926 em Russo, com a última versão em Inglês publicada em 1992.

Neste trabalho Vavilov e seus colaboradores introduziram o conceito de CENTROS DE ORIGEM que de forma geral descreve os padrões de distribuição da variação de plantas cultivadas pelo homem. Por este conceito, a diversidade dessas plantas está distribuída de forma desigual no planeta, sendo que as áreas de maior diversidade são aquelas que se apresentavam de alguma forma isolada com condições de solos e de climas próprios e, por isso, são seus locais de origem. De acordo com Vavilov, "O local de origem de uma espécie de uma planta cultivada é para ser achado em uma área na qual contém a maior número de variedades genéticas desta planta."

O termo centro de origem usado por Vavilov é frequentemente confundido por centro de diversidade, na verdade o primeiro é uma interpretação e o segundo um fato biológico. Vavilov propõem que a maioria das plantas cultivadas está distribuída em oito centros de origem de alguma forma isolada em áreas localizadas em um pequeno número de países, a saber: (I) Chinês; (II) Indiano; (IIa) Indo-Malaio; (III) Asiático Central; (IV) Oriente Próximo; (V) Mediterrâneo; (VI) Abissínio (atual Etiópia); Mexicano do sul e Centro-Americano; (VIII) Sul-Americano; (VIIIa)Chiloé (arquipélago ao sul do Chile) e (VIIIb) Brasileiro-Paraguaio. É importante salientar que Vavilov reconheceu a existência de centros secundários de origem, nos quais se desenvolvem variedades vindas de centros primários. Fenômenos genéticos, tais como mutações e hibridizações naturais que podem ocorrer nos centros secundários possibilitam o aparecimento de novas variedades, aumentando, assim, a variabilidade genética da espécie.

É importante reconhecer que as ideias expressas por Vavilov sobre centros de origem (centros de diversidade) de certa forma foram uma interpretação das ideias propostas por John Christopher Willis (1868-1958), botânico Inglês que propôs o que ficou conhecido como Willis' age-and-area bypothesis (WILLIS, 1915). Por esta proposição, agentes seletivos promovidos pelo ambiente operam da mesma forma sobre um grupo de espécies em um determinado local. Desta forma, quanto mais tempo uma ou mais espécies ocupam uma região maior será sua área de abrangência, e que o desaparecimento de uma espécie não ocorre usualmente a não ser como 
resultado de mudanças ambientais drásticas. Esta ideia de certa forma introduziu o conceito de endemismo, muito utilizado na genética na conservação.

\subsection{O que são Recursos biológicos, Recursos genéticos, Patrimônio genético.}

Ao longo deste século, principalmente a partir da década de 1960, vem ocorrendo um crescente reconhecimento da importância da preservação dos ambientes e dos organismos que neles vivem. Este reconhecimento tem uma relação estreita com a sobrevivência e o bem estar de uma única espécie - o Homo sapiens (CHIVIAN; BERNSTEIN, 2008). As ações oriundas da sociedade colocaram a questão ambiental na pauta de discussão dos órgãos nacionais e internacionais de decisão, situação que não era comum na primeira metade do século XX. Contudo, ao contrário de tempos geológicos pretéritos, nos quais as extinções em massa ocorriam por mudanças climáticas extremas; nos tempos atuais processos de extinções de espécies têm como causa as atividades humanas. Principalmente, no que se refere à perda de hábitats (TILMAN et al., 1994) e mais recentemente pelo aquecimento global (THOMAS et al., 2004).

Atualmente, diferentes órgãos nacionais e internacionais propõem terminologias para estabelecer parâmetros legais do uso da biodiversidade. Allem (2000) analisou a definição de conceitos como: recursos genéticos e recursos biológicos, e mostrou que tais conceitos são usados de forma indiscriminada, levando ao estabelecimento de interpretações equivocadas sobre as bases científicas destes termos.

Em 1991, na reunião intergovernamental de Nairóbi promovido pelo Programa Ambiental das Nações Unidas, o termo "Recursos Biológicos" surge, e é usado pela FAO pela primeira vez (UNEP, 1991). O documento do comitê intergovernamental de negociação para convenção sobre a diversidade biológica, em sua quarta e segunda rodadas de negociação (na reunião de Nairobi), foi a base para cunhar terminologias para o artigo dois (termos para uso) do documento final da Convenção sobre Diversidade Biológica (CBD, 92). Neste artigo, percebe-se que as definições usadas para Recursos Genéticos e Recursos Biológicos (Material Genético) são bastante similares.

O conceito de Recursos Genéticos também aparece na Conferência de Leipzig promovido pela FAO em 1996. Este conceito trás em seu cerne a ideia de utilitarismo dos recursos vivos, e se refere aos recursos genéticos como os recursos dos quais se obtêm algum tipo de riqueza. Contudo, a sobrevivência de tais recursos depende muitas vezes da sobrevivência de outros recursos não diretamente útil para o homem. Na tabela 1 está apresentado um resumo 
das definições dos conceitos de Recurso Biológico e Genético desenvolvido por diversas organizações internacionais.

Uma análise mais detalhada sobre todas as definições faz com que os conceitos de Recurso Biológico e Recurso Genético se sobreponham e aborde um mesmo objetivo, que é o uso da variabilidade genética de organismos biológicos para geração de produtos úteis a humanidade.

No Brasil, a carta magna de 1988 utiliza o termo Patrimônio Genético como um bem constitucionalmente protegido. Este termo, como definido por meio da Medida Provisória n. 2.186-16 de 23 de agosto de 2001, consiste em: “toda a informação de origem genética, contida em amostras do todo ou de parte de espécime vegetal, fúngico, microbiano; ou animal, na forma de moléculas e substâncias provenientes do metabolismo desses seres vivos, e de extratos obtidos desses organismos vivos ou mortos encontrados em condições in situ e inclusive domesticados; ou mantidos em condições ex situ, desde que coletados in situ no território nacional na plataforma continental ou na zona econômica exclusiva".

O Conselho de Gestão do Patrimônio Genético (CGEN) é o órgão normativo e deliberativo do governo brasileiro, ligado ao ministério do Meio Ambiente que regula e avalia os projetos de acesso ao aqui chamado patrimônio genético brasileiro com o objetivo de pesquisa científica, bioprospecção e desenvolvimento tecnológico. Desta forma, o termo patrimônio genético (ou Genetic Heritage) está relacionado ao conceito de recursos genéticos definidos pela CBD (1992) e usado em termos legais no Brasil.

Tabela 1. Conceituações dos termos: Recursos Biológicos e Recursos Genéticos

\begin{tabular}{|c|c|c|}
\hline Conceito & Definição & Fonte \\
\hline \multirow[t]{4}{*}{ RecursosBiológicos } & Termo é citado sem uma devida definição. & UNEP, (1991) \\
\hline & $\begin{array}{l}\text { "Compreende os recursos genéticos: } \\
\text { organismos ou partes destes, populações, } \\
\text { ou qualquer outro componente biótico } \\
\text { dos ecossistemas que apresentem } \\
\text { potencial utilidade para a humanidade". }\end{array}$ & CBD, (1992) \\
\hline & $\begin{array}{l}\text { Componentes da biodiversidade de } \\
\text { uso direto, indireto ou potencial uso } \\
\text { pela humanidade (= recursos } \\
\text { bióticos). }\end{array}$ & WRI, (1996) \\
\hline & $\begin{array}{l}\text { "Recursos florestais, de cultivo de plantas, } \\
\text { aquáticos e de animais que não sejam } \\
\text { aquáticos, cujo uso traga benefícios hoje } \\
\text { ou que possam trazer no futuro. Cada } \\
\text { categoria de recurso biológico é } \\
\text { subdividida em subcategorias cultiváveis e } \\
\text { não cultiváveis". }\end{array}$ & OECD, (2013) \\
\hline
\end{tabular}


Tabela 1. Contiuação

\begin{tabular}{|c|c|c|}
\hline Recursos Genéticos & \multirow{2}{*}{$\begin{array}{l}\text { "Material de plantas com valor } \\
\text { potencial e presente para } \\
\text { alimentação, agricultura e } \\
\text { floresta". } \\
\text { "Germoplasma de plantas, } \\
\text { animais ou outros } \\
\text { organismos que contenham } \\
\text { caracteres úteis de valor real } \\
\text { ou potencial". }\end{array}$} & $\begin{array}{c}\text { Plant Genetic Resource - } \\
\text { (BROCKHAUS; } \\
\text { OETMANN, 1996) }\end{array}$ \\
\hline & & IBPGR (1991) (p. 74) \\
\hline & $\begin{array}{l}\text { "Recursos genéticos de plantas } \\
\text { referem-se aos valores } \\
\text { econômicos, científico e social } \\
\text { que contenham materiais } \\
\text { herdáveis dentro e entre } \\
\text { espécies". }\end{array}$ & FAO (1989) (p. 19) \\
\hline & $\begin{array}{l}\text { "Material genético: todo } \\
\text { material de origem vegetal, } \\
\text { animal, microbiana ou outra } \\
\text { que contenha unidades } \\
\text { funcionais de } \\
\text { hereditariedade". } \\
\text { "Recursos genéticos: } \\
\text { material genético de valor } \\
\text { real ou potencial." }\end{array}$ & CDB, (1992) \\
\hline & $\begin{array}{l}\text { "Material genético de plantas, } \\
\text { animais e microorganismos } \\
\text { que possuam valor para } \\
\text { futuras gerações } \\
\text { humanidade". }\end{array}$ & OECD, 2013 \\
\hline
\end{tabular}

\subsection{A importância dos recursos genéticos para a produção de alimentos.}

A melhora da qualidade de vida do homem ao longo do último século amentou sua expectativa de sobrevida. A expectativa global de sobrevida ao nascer está hoje em 68 anos, quatro anos a mais do que em 1990 (WHO, 2013) e 21 anos mais dos que aos nascidos entre 1950 e 1955 (HOSSEINPOOR et al., 2012). A projeção de aumento populacional humano advindo das melhores condições de vida para os próximos anos é de certa forma preocupante. Atualmente a população de uma única espécie, o Homo sapiens, chegou aos incríveis sete bilhões de indivíduos (UNFPA, 2004).

Atualmente, apesar dos avanços nas tecnologias de produção de alimentos, ainda temos no mundo 852 milhões de pessoas sem a alimentação mínima adequada para sua sobrevivência e bem estar, principalmente em países subdesenvolvidos e em desenvolvimento, e 16 milhões subnutridas em países desenvolvidos (FAO; WFP; IFAD, 2012). O aumento populacional deverá 
ser acompanhado com o aumento na produção de alimentos, porém, em um cenário com menos água, menos terra e talvez com condições ambientais menos favoráveis.

A importância da conservação dos recursos genéticos no contexto da produção de alimentos (face ao exposto no item anterior, passamos a usar o termo Recursos genéticos (RG) dentro dos termos da CBD, 1992) reside no fato de que grande parte das riquezas produzidas pelo homem para sua sobrevivência e bem-estar ainda tem a natureza como sua principal fonte.

O grande salto na produção de alimentos no mundo veio com o que foi chamado em 1968, pelo então diretor da USAID (United States Agency for International Development), William Gaud de Revolução Verde, em suas palavras (GAUD, 1968).

"These and other developments in the field of agriculture contain the makings of a new revolution. It is not a violent Red Revolution like that of the Soviets, nor is it a White Revolution like that of the Shah of Iran. I call it the Green Revolution.”

A Revolução Verde teve como marco a iniciativa do agrônomo norte-americano Norman Ernest Borlaug (1914-2009), laureado como Premio Nobel da Paz em 1970, que liderou o desenvolvimento de variedades de plantas geneticamente melhoradas, como a variedade de arroz IR8. A percepção de que novas variedades com potencial produtivo quando comparado com as variedades locais juntamente ao desenvolvimento de novas técnicas de manejo do solo, uso de pesticidas, facilidade na distribuição de sementes melhoradas e mecanização agrícola fizeram com que a produtividade das principais culturas vegetais mais do que dobrassem em um período de meio século, principalmente a partir da década de 1960.

$\mathrm{O}$ advento de modernas tecnologias agrícolas e a expansão do uso de variedades melhoradas incrementou a produtividade de alimentos em diversas partes do planeta. Ao longo do tempo, a diversidade de variedades de plantas cultivadas desenvolvidas pelos nossos antepassados, que foram formadas em razão das diferentes condições de cultivo e necessidades locais, foi sendo substituídas pelas variedades melhoradas (FRANKEL; HAWKES, 1975; BARLETT, 1980). O aumento da produtividade também trouxe consequências; o plantio de vastas áreas com cultivares geneticamente uniformes faz com que tais cultivares estejam vulneráveis ao ataque de pragas e, por isso, altamente dependentes de pesticidas e outros defensivos agrícolas (ADAMS et al., 1971).

A erosão dos recursos genéticos, base para os programas de melhoramento genético, levantou a questão de como a diversidade genética de plantas deveriam ser resguardada do avanço inevitável do estabelecimento dos cultivares melhorados (PLUCKNETTT et al., 1983). A crescente preocupação internacional com a perda de recursos genéticos de importância para 
produção de alimentos, e consequentemente com o aumento da vulnerabilidade de cultivares melhorados levou à criação em 1974 do Conselho Internacional para Recursos Genéticos de Plantas (International Board for Plant Genetic Resources - IBPGR), uma organização internacional sob os auspícios do Grupo Consultivo em Pesquisa Internacional de Agricultura (Consultative Groupon International Agricultural Research - CGLAR), cuja missão tem sido a conservação e uso dos recursos genéticos de plantas para o benefício das gerações presentes e futuras.

Uma das iniciativas da IBPGR foi estimular a formação de bancos de germoplasma onde sementes que representem a diversidade genética de variedades locais pudessem ser armazenadas, catalogadas e seu potencial de uso possam ser avaliadas (FRANKEL; BENNETT, 1970). Ao longo dos anos, diversos bancos de germoplasma ex-situ têm sido estabelecidos por iniciativas governamentais. A FAO (2010) por meio do Second Report on the State of the World's Plant Genetic Resources for Food and Agriculture enfatizou o progresso na expansão da quantidade de variedades de plantas mantidas em bancos nacionais de germoplasma. Atualmente, são estimados que 1.750 bancos de germoplasma estejam estabelecidos em todo o mundo, que juntos conservam cerca de 7,4 milhões de acessos, um aumento de 20\% desde a última avaliação em 1996.

É importante salientar que a FAO destaca que várias são as razões para a conservação dos recursos genéticos para alimentação e agricultura, e que isto é fundamental para resguardar a adaptabilidade de cultivares e populações selvagens de maneira a preservar características genéticas que assegurem uma produção sustentável de alimentos. Para isto, recursos genéticos vegetais e animais devem ser conservados ex-situ e in-situ. Estes bancos são definidos pela FAO (2012) da seguinte maneira:

Conservação ex-situ: compreende a conservação dos componentes da diversidade biológica fora de seus ambientes naturais e mantidos em locais fora de suas condições normais de manejo. A principal infraestrutura de armazenamento para o estabelecimento das técnicas para tal conservação é os chamados bancos de genes (bancos de germoplasma). A conservação ex-situ in vitro é outra modalidade de manutenção do germoplasma em ambientes artificiais, isto inclui manter esperma, ovócito, embriões, células somáticas, tecidos em criopreservação que tenham o potencial de reconstituir um organismo vivo.

Conservação in-situ: é a manutenção e recuperação de populações viáveis de espécies em seu ambiente natural, e no caso de espécies domesticadas ou cultivadas, no ambiente onde elas desenvolveram suas distintas características. Abordagens comuns para conservação in-situ são a conservação de reservas genéticas e a conservação em locais de cultivo e/ou criação.

A convenção sobre diversidade biológica estabelece que a conservação in-situ, a preservação das populações e espécies em seus habitats naturais, deve receber prioridade sobre a 
conservação ex-situ no qual populações, espécies, juvenis e gametas são conservados fora do seu ambiente natural (em parques, zoológicos, aquários, criadouros ou bancos genéticos). Aqueles que acreditam fortemente na conservação in-situ preocupam-se que a remoção de organismos ou gametas do seu local de origem (ex-situ) possa levar a interrupção do processo evolutivo da espécie, aumentando a dependência por soluções tecnológicas para os problemas ambientais e, sobretudo causando o desvio das atenções e investimentos na solução de problemas que ameaçam as espécies em seus ambientes naturais. Entretanto, nem sempre é possível realizar conservação in-situ tão rapidamente quanto seria desejável para salvar espécies e/ou populações em risco severo de extinção. Os proponentes da conservação ex-situ argumentam que suas coleções também são importantes para pesquisa e referência e que tal estratégia possa ser mais efetiva do ponto de vista de custos.

\subsection{Os recursos genéticos animal.}

A criação de animais terrestres com total controle do homem foi possível com a domesticação de espécies selvagens que serviram de base para a seleção de indivíduos mais adaptados ao convívio com o homem.

Os registros mais antigos de domesticação de animais mostram que os lobos foram os primeiros a serem domesticados pelo homem ao final do período glacial pelos caçadores/coletores da Europa e Ásia (BENECKE, 1987; SAVOLAINEN et al., 2002). O plantio de culturas e a domesticação animal iniciaram grandes mudanças no modo de vida do homem que aos poucos perde o comportamento nômade, estabelecendo sociedades que obrigaram a formação de uma organização social que levou ao surgimento de diferentes civilizações ao longo da história do homem na terra. Este processo foi conhecido como Neolitização (Neolithisation) (VIGNE, 2011). Segundo este mesmo autor uma parte muito pequena da diversidade animal do planeta foi ou tem sido domesticada e usada como alimento pela maioria das populações humanas. Como exemplo, o auroque (Bos primigenius) espécie préhistórica extinta no século XVII e que deu origem ao atual Bos taurus (HELMER et al., 2005).

A necessidade da conservação dos recursos genéticos animais de interesse para produção de alimentos foi pela primeira vez expressa em 1959, em um simpósio sobre recursos de germoplasma para melhoristas animal e vegetal (SIMON, 1984). Os recursos genéticos animais contribuem de muitas maneiras para a sobrevivência do homem. Cerca de 30\% do total dos requerimentos da espécie humana para alimentação e agricultura advém dos animais de criação com uma perspectiva de atingir 39\% em 2030 (FAO, 2007). A contribuição do alimento e subprodutos animais é também muito significativa para cerca de $70 \%$ da população rural 
principalmente em países pobres e em desenvolvimento (LIVESTOCK IN DEVELOPMENT, 1999).

Segundo a FAO (2007), os recursos genéticos animais para alimentação e agricultura compreendem hoje 7.616 raças de animais de criação, sendo que cerca de 20\% destas são categorizadas como ameaçadas. Este quadro torna-se ainda pior quando se tem registrado que nos últimos seis anos 62 raças desapareceram, acrescenta-se a isto a ausência de dados populacionais sobre 36\% de todas as raças que de alguma forma são criadas pelo homem. Este quadro de erosão dos recursos genéticos animais indica uma tendência de piora em face de: (i) da introdução de raças geneticamente homogêneas e produção intensiva; (ii) pressão ambiental sobre os recursos naturais, indisponibilizando áreasde criação de raças locais; (iii) políticas de desenvolvimento e estratégias de gestão inadequadas de países que de alguma maneira ignoram em suas políticas os recursos genéticos animais locais adaptados ao longo dos anos aos sistemas de criação com menor introdução de insumos.

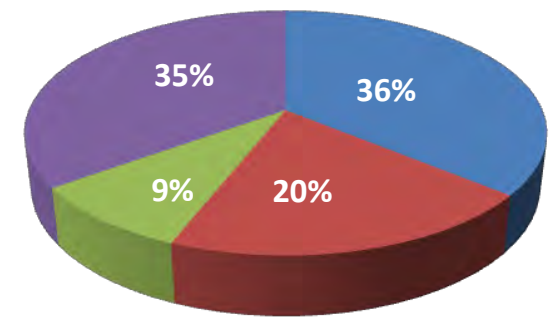

\author{
Desconhecida \\ - Em perigo de extinção \\ Extinta \\ Fora de perigo
}

Figura 2. Proporção das raças do mundo de todas as espécies em criação por categoria de risco de extinção (Adaptado FAO, 2007).

No Brasil, a maioria das espécies animais utilizadas na pecuária foi introduzida em períodos sucessivos no início da colonização. Os reprodutores de diferentes espécies trazidos pelos portugueses após o descobrimento se estabeleceram em diferentes regiões do país, sendo submetidos a condições diversas de deriva genética e seleção natural. Estes animais desenvolveram características adaptadas às condições brasileiras e foram conhecidas como tipos “criollo”, local ou naturalizada (MARIANTE; EGITO, 2002; MARIANTE et al., 2009)

A grande maioria dos animais utilizados para produção de alimentos compreende o grupo dos mamíferos e das aves. A domesticação de novas espécies destes dois grupos para criação em cativeiro tem sido rara. 


\subsection{Sobre os recursos genéticos de peixes de água doce no mundo}

Nos tópicos anteriores abordamos historicamente a conceituação desenvolvida pelos diversos organismos internacionais sobre recursos biológicos e recursos genéticos. Tais conceitos foram baseados principalmente em plantas de importância para agricultura e animais de criação terrestres. Ao contrário dos animais terrestres, a proteína advinda de organismos aquáticos é ainda em sua grande maioria feita pelo extrativismo no caso da pesca, sendo que ainda hoje novas espécies têm sido incorporadas via domesticação em sistemas de criação.

Bartley e Pullin (1999), propuseram uma questão importante no que se refere aos recursos genéticos aquáticos (RGAq) - "Tudo que vive em um ambiente aquático e possui vida e todo material genético (DNA) contido nestes organismos tem real ou potencial valor?”. Esta afirmação levanta uma questão importante sobre a magnitude da biodiversidade em oceanos e águas continentais, e as lacunas de conhecimento sobre tal biodiversidade. No caso do interesse direto e indireto de organismos aquáticos para alimentação, alguns pontos devem ser ressaltados: (i) como os ecossistemas aquáticos funcionam e mantêm a produção pesqueira? (ii) qual a situação de sustentabilidade dos estoques pesqueiros face às intensas e constantes modificações ambientais promovidas pelo homem no último século? (iii) quais critérios devem ser usados para escolher espécies aquáticas para domesticação? (iv) como transformar tais espécies de forma rápida em alimento diário para as populações humanas?

Em razão de suas particularidades, os RGAq devam abranger diversos níveis hierárquicos: genes, variedades ou "raças", populações, espécies e ecossistemas. Em se tratando de espécies de valor comercial seja para pesca ou para aquicultura e levando em consideração a extrema dependência destas espécies com o ecossistema aquático e com outras espécies; o que podemos realmente caracterizar como recursos genéticos? Devemos apenas considerar espécies alvos da pesca como recursos genéticos, ou devemos incluir outras espécies sem valor comercial, que são fundamentais para sustentabilidade das espécies alvos. Esta questão foi especialmente destacada no documento Executive Summary for Policy-Makers of Global Biodiversity Assessment (UNEP, 1995) da seguinte forma:

"A terra é o lar para um rico e diverso conjunto de organismos viventes, cuja diversidade genética com suas inter-relações, bem como sua interação com ambiente físico constitui a biodiversidade de nosso planeta".

O ambiente aquático no planeta terra sempre pareceu uma fonte inesgotável de alimentos e riquezas para a humanidade. O incremento tecnológico atrelado à pesca fez com que o mito de que os recursos biológicos aquáticos são uma fonte inesgotável fosse colocado em dúvida. Tais recursos podem sim ser finitos se não propriamente manejados. O código de conduta para pesca 
responsável da FAO (2011) estabeleceu dez objetivos claros que devem ser seguidos para uma sustentabilidade em longo prazo dos RGAq. Dentre eles, podemos destacar: (i-f) promover a contribuição dos produtos da pesca para a seguridade e qualidade alimentar, dando prioridade para as necessidades nutricionais das comunidades locais. (ii-g) promover a proteção dos recursos aquáticos viventes e seus ambientes e áreas costeiras.

No presente trabalho a ênfase será dada aos RGAq de águas continentais. A importância de tais recursos para economia e produção de alimentos em diversos países é inegavelmente importante. WELCOMME, (2011) destaca que os dados da produção pesqueira advinda de águas continentais mostram que em todos os continentes as capturas estão em declínio, espécies estão desaparecendo devido entre outras razões a sobrepesca. Seis têm sido as principais ameaças a sustentabilidade da pesca em águas continentais enfatizada pelo trabalho:

(i) Gestão da pesca ruim ou inexistente: incluindo a pesca descontrolada eexcessiva, pesca com tamanho de malha inadequado ou ilegal, e introdução de espécies exóticas e invasoras.

(ii) Captação de água: há uma crescente tendência de desvio de rios para captação de água diretamente ou de reservatórios para irrigação de culturas agrícolas.

(iii) Drenagem de áreas alagadas: há uma crescentetendência para drenar pântanos e separar áreas de várzeas da calha do rio. Isso resulta em perda das áreas de alimentação e reprodução e, com isto coloca-se em risco muitas comunidades de peixes;

(iv) Construção de barragens: com a crise de combustível que o mundo enfrenta, tem havido um aumento na construção de grandes barragens da geração de energia elétrica. Os impactos das barragens sobre a fauna de peixes nativos não têm sido avaliados devidamente. Acredita-se que os efeitos da interrupção do rio sobre a abundância de peixes utilizados na pesca possa ser compensado pela formação de reservatórios;

(v) Poluição/eutrofização: poluição tem importantes efeitos locais em rios e em lagos. A eutrofização é uma ameaça crescente com oaumento da ocupação por comunidades humanas de áreas próximas a rios, lagos e reservatório sem as medidas apropriadas de tratamento de esgotos nestes locais;

(vi) Mudança climática: a variação climática tem sido um sério problema, especialmente nas regiões propensas à seca. Estes efeitos tendem a se tornar mais gravecom oa vanço do aquecimento global.

Apesar das inúmeras modificações ambientais experimentadas globalmente pelos ecossistemas aquáticos continentais, a pesca em águas interiores vem registrando aumentos de captura, mesmo levando em consideração que em muitos países não há registros de parte da 
produção advindos da pesca de pequena escala. A contribuição da pesca interior no total de pescado produzido no mundo é de $6,46 \%$, o que significa $2,3 \%$ da contribuição da proteína animal consumida. Praticamente todo este pescado é consumido de alguma forma pelas comunidades locais que é capturado pela pesca não industrial e, com algumas poucas exceções, em escala de subsistência (FAO, 2012).

Mesmo com a aparente pouca contribuição da pesca de água doce na produção mundial de pescado, a captura em rios, lagos e reservatórios figura como o sexto maior fornecedor de proteína animal para as populações humanas $(2,3 \%)$, ficando atrás da carne de porco $(23,68 \%)$, pescado marinho (19,86\%), carne de frango (17,77\%), peixe de piscicultura (15,26\%), carne de gado (13,80\%) (WELCOMME, 2011). É importante salientar que 38\% do pescado de água doce são originários de 71 países considerados como países com déficit alimentar como definido pela FAO (www.fao.org/countryprofiles/lifdc.asp), cujas populações dependem fortemente desta fonte de proteína animal.

Os dados gerados pela FAO (WELCOMME, 2011) mostram que as capturas de organismos de água doce têm crescido linearmente desde 1950 até 2009 a uma taxa de 2,93\% ao ano e atualmente soma um total de 10.323 .905 t (Figura 3). Deste total, peixes representam $90,5 \%$ com uma captura de 9.343.658 t.

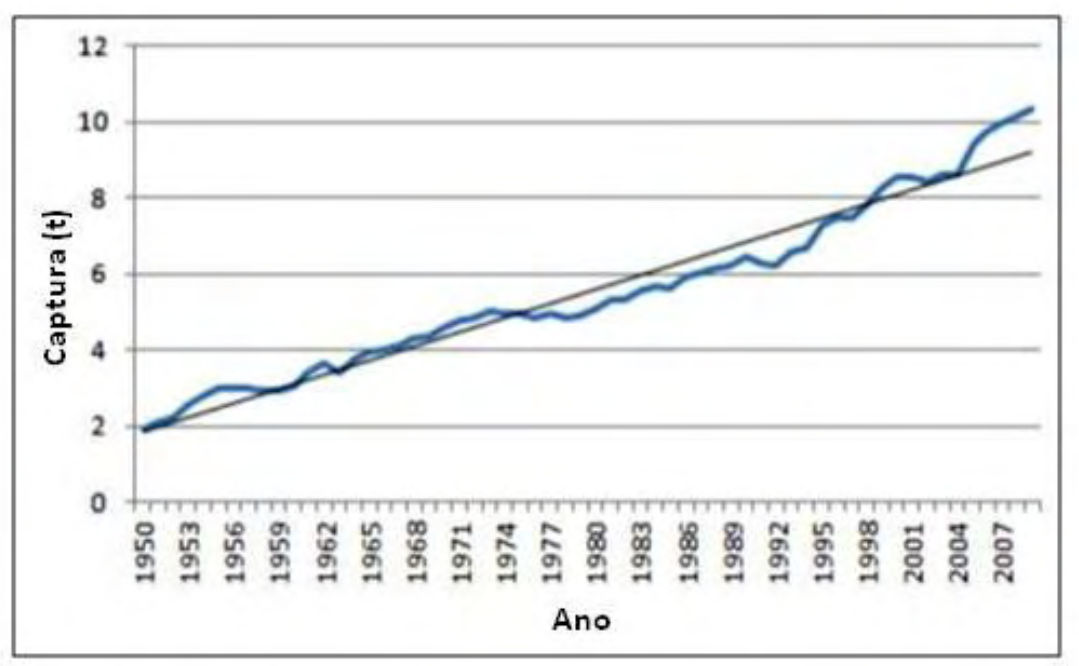

Figura 3. Produção pesqueira de águas continentais de 1950 a 2009 (WELCOMME, 2011). 
A importância dos recursos genéticos de peixes de água doce no contexto da produção de proteína animal para alimentação humana é evidente quando se registra que 76 grupos taxonômicos de peixes contribuem com 95\% do total de capturas. São 30 famílias principais, dentre as quais se destacam a Cyprinidae, representadas principalmente pela carpa comum, carpas chinesas e carpas indianas com 22,23\%, e a Cichlidae representada pelas tilápias com 20,38\% do total da produção (WELCOMME, 2011).

A produção de peixes em cativeiro tem sido outra forma de produção de proteína animal que apesar de registros antigos da prática de criar peixes em sistemas controlados pelo homem para alimentação (BALON, 1995), somente nos últimos 50 anos esta atividade se expandiu significativamente em escala global.

Em seu último documento sobre o estado da pesca e aquicultura no mundo (FAO/SOFIA, 2012), a FAO registrou que a produção aquícola hoje representa 46\% do total do suprimento de pescado para alimentação. No total 115 milhões de toneladas são atualmente usados como alimento para a humanidade, provendo uma estimativa $17 \mathrm{~kg}$ per-capita de pescado. Os dados apresentados pela FAO mostram claramente que a pesca tanto marinha como de água doce tem se mantido estável nos últimos cinco anos, sendo que no caso da pesca marinha observa-se um declínio de 83,8 milhões de ton. em 2004 para 79,9 milhões de ton. em 2009. No caso da produção de pescado em cativeiro de água doce, a produção apresentou um aumento de $39 \%$ de 2004 (25,2 Mt) a 2009 (35 Mt) (Figura 4).

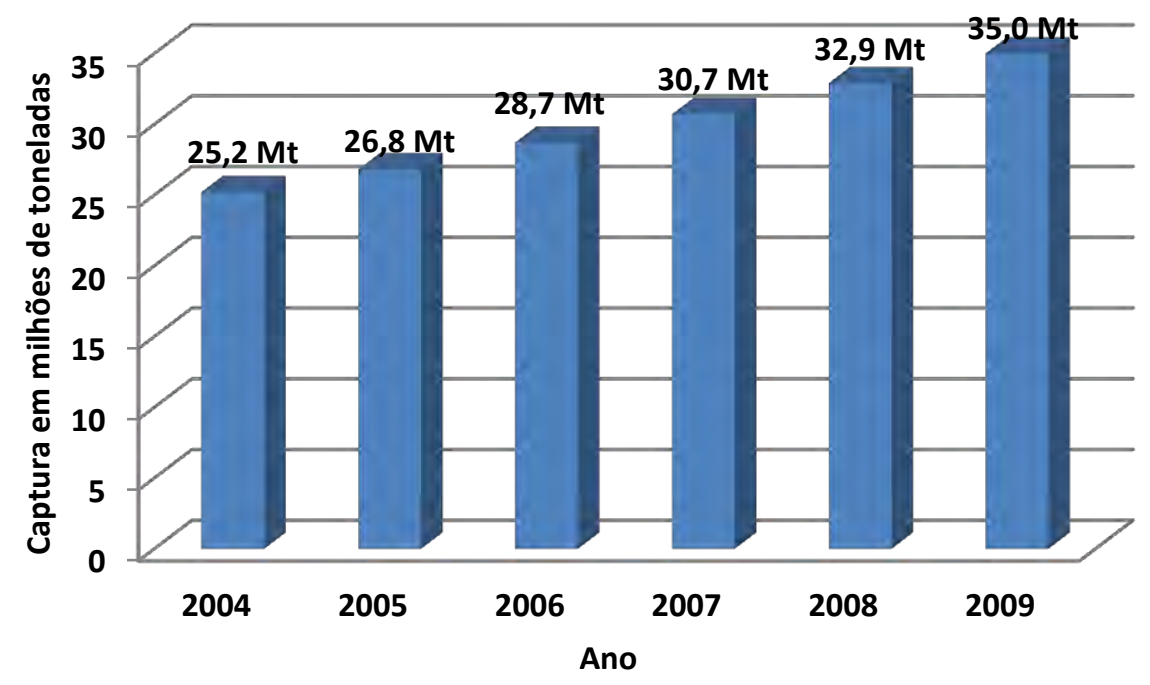

Figura 4. Captura mundial de peixe de água doce 
Os dados apresentado acima demonstram claramente que os organismos aquáticos, peixes em especial, são importantes fontes de alimentos para sobrevivência e para geração de riquezas em praticamente todos os continentes. Especificamente no caso de recursos genéticos de águas continentais, tais recursos ainda estão mal avaliados e em vários níveis ameaçados. A pesca efetuada sem um manejo adequado pode impactar as populações selvagens, causando mudanças na distribuição etária das populações, na idade da primeira reprodução, na estrutura genética e na composição das espécies (BOEHLERT, 1996).

Já no caso da Aquicultura, a sustentabilidade dos sistemas produtivos depende de diversas variáveis, especificamente dentro do ponto de vista das espécies, tais como a manutenção da variabilidade e a integridade genética das populações são fundamentais para a domesticação de novas espécies, bem como do melhoramento genético das espécies atualmente em criação. O uso dos recursos genéticos de peixes em países subdesenvolvidos, em desenvolvimento ou mesmos os desenvolvidos para produção de alimentos requer uma avaliação criteriosa em relação ao uso compartilhado dos benefícios gerados pelo uso de tais recursos (BARTLEY et al., 2009). Um exemplo desta situação é o uso praticamente globalizado da tilápia na produção aquícola mundial, cuja origem e os recursos genéticos estão no continente africano (PULLIN, 1988; EKNATH; HULATA, 2009).

\subsection{Sobre os recursos genéticos de peixes nativos de água doce no Brasil}

O Brasil é um país que por suas características de possuir grandes sistemas biogeográficos com clima tropical a subtropical possibilitou o desenvolvimento de uma megadiversidade da fauna de peixes de água doce (NOGUEIRA et al., 2010). São 2.587 espécies, sendo 2.481 formalmente descritas, isto representa por volta de $21 \%$ da totalidade de espécies de águas interiores do mundo (BUCKUP et al., 2007). Reis et al. (2003) estimaram que de 30 a 40\% desta ictiodiversidade pode ainda não ter sido descrita podendo o total de espécies de peixes de águas doce chegar a 5.000 .

Apesar da ampla ictiodiversidade presente no Brasil, o número de espécies utilizadas economicamente pela pesca e aquicultura é pequena. De acordo com o Boletim estatístico da pesca e aquicultura do Ministério da Pesca e Aquicultura (MPA, 2010), 72 espécies estão nominalmente catalogadas em termos de produção pesqueira em praticamente todas as bacias hidrográficas no Brasil, e estão distribuídas nas seguintes famílias: Engraulidae, Clupeidae, Osteoglossidae, Characidae, Erythrinidae, Cynodontidae, Prochilodontidae, Curimatidae, Anostomidae, Hemiodontidae, Pimelodidae, Doradidae, Ageneiosidae, Hypophthalmidae, Loricariidae, Callichthydae, Atherinidae, Sciaenidae e Cichlidae (Lowe-McConnell, 1984). 
A pesca de água doce é uma atividade tradicional em algumas regiões do Brasil, sendo em muitos casos a única fonte de proteína disponível para as populações ribeirinhas. A pesca em represas formadas para geração de energia elétrica e abastecimento também se tornou uma fonte de renda e sustento para alguns estratos populacionais (PETRERE JR. et al., 2006). Além da pesca profissional, a pesca esportiva tem se transformado em uma das principais atividades de captura de peixes de água doce no Brasil. De acordo com Petrere Jr., (1995) a pesca continental no Brasil é praticada de forma intensiva na bacia amazônica, nos açudes nordestinos, na bacia do rio São Francisco, em rios da bacia do leste, como o rio Paraíba do Sul, na bacia do Paraná e no Pantanal.

$\mathrm{Na}$ estatística da pesca continental, o Brasil aparece em décimo segundo lugar com 2,5\% da produção mundial de captura de pescado de água doce. A captura em águas continentais brasileiras apresentou uma produção média de 245.099 t (Figura 5), sendo que a produção em 2011 atingiu os 248.911 t (MPA, 2010).

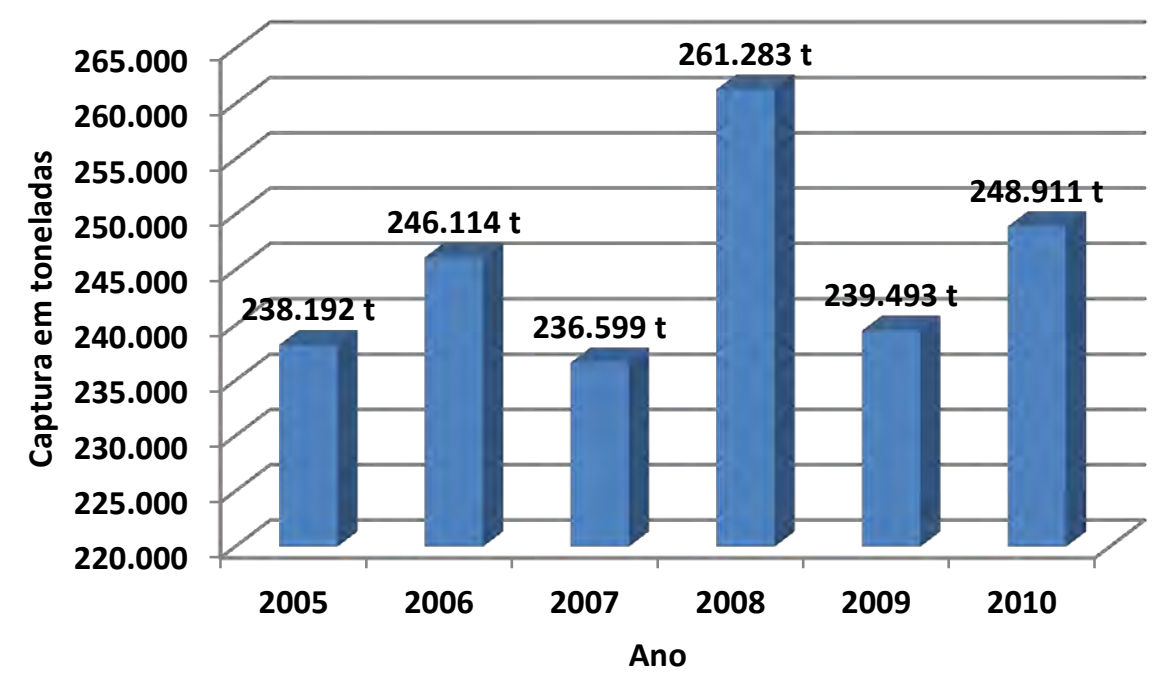

Figura 5. Quantidades de peixes capturados pela pesca em águas continentais nos últimos cinco anos.

A produção de peixes em cativeiro é a atividade que mais cresceu no âmbito da produção de proteína animal no Brasil. De acordo com o MPA (2010), o crescimento da produção de proteína animal advindo da produção aquícola quando comparado com outras formas mais tradicionais de produção de carne, tais como bovinos, aves e suínos entre 2007 e 2009, foi de 43,8\%. A produção de organismos aquáticos em cativeiro como um setor economicamente organizado é relativamente recente no Brasil (Figura 6). 
O Brasil por suas dimensões geográficas e sua significativa diversidade de espécies nativas desenvolveu uma piscicultura diversificada nas diferentes regiões do país. As estatísticas do MPA mostram que no Brasil a produção de peixes em cativeiro está baseada em 16 espécies e dois híbridos interespecíficos. Destas espécies há cinco espécies exóticas - bagre africano (Clarias gariepinus), bagre americano (Ictalurus punctatus), tilapia (Oreochromis sp.), carpa (Cyprinus carpio) e truta arco-íris (Oncorbynchus mykiss) que correspondem a 65,7\% do total da produção nacional em 2010 de 394.340 t.

As estimativas de produção em 2007 por espécies de peixes mostraram que apesar da relevante ictiodiversidade presente no Brasil as principais espécies utilizadas nos diferentes sistemas de criação são espécies introduzidas de outros países, tais como tilápia (Oreochromis sp.), carpas comum, capim, prateada, cabeça grande (Cyprinus carpio, Ctenopharyngodon idella, Hypophthalmichthys molitrix e Aristichthys nobilis, respectivamente), trutas (Oncorbynchus mykiss) e bagres (Clarias gariepinus e Ictalurus punctatus). Das espécies nativas do Brasil, 12 estão registradas com algum nível de produção em cativeiro, e estas correspondem a 24,6\%, sendo que $2,9 \%$ correspondem a outros grupos animais, tais como crustáceos, anfíbios e quelônios.

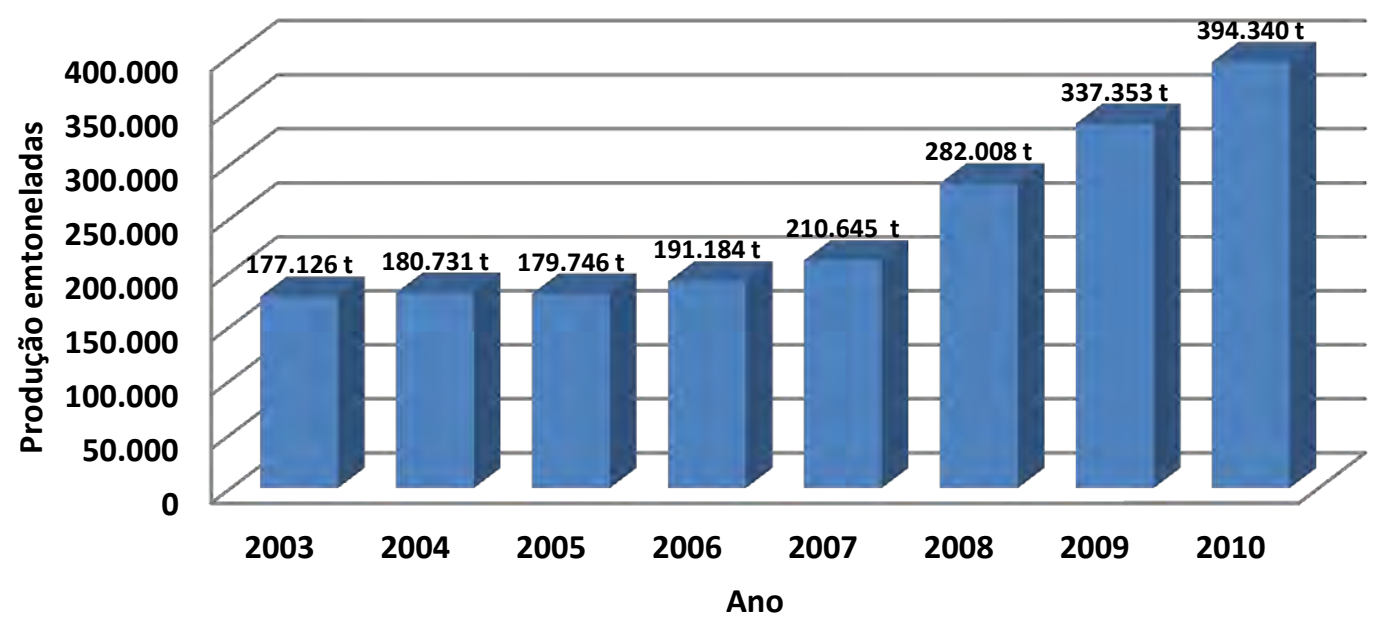

Figura 6. Produção de peixe em cativeiro no Brasil de 2003 a 2010.

Das espécies nativas das bacias hidrográficas brasileiras, o tambaqui é a espécie de maior produção $(54.313,10$ t), sendo que sua produção está concentrada principalmente nas regiões norte e nordeste. O levantamento do MPA mostra também que dois híbridos aparecem nas estatísticas de produção; o tambacu - cruzamento da fêmea do tambaqui (Colossoma macropomum), com o macho do pacu (Piaractus mesopotamicus) com uma produção de $21.621,40$ t (5,5\% do total), e a tambatinga resultado do cruzamento da fêmea do tambaqui com o macho da pirapitinga amazônica (Piaractus brachypomum) com uma produção de 4.915,60 
t $(1,2 \%$ do total). Outras espécies nativas também são criadas em sistemas mais extensivos cuja produção não é registrada pelas estatísticas do MPA.

O panorama da piscicultura brasileira mostra algumas características peculiares. Primeiro mais de 50\% da produção nacional depende de espécies exóticas, particularmente a tilápia que responde por 39,54\% da produção nacional de água doce. Segundo, híbridos interespecíficos já aparecem nas estatísticas oficiais de produção. Estas duas características são importantes no que se refere aos recursos genéticos de espécies nativas de peixes usadas na produção de alimentos.

A introdução de espécies exóticas e a translocação de espécies de uma bacia hidrográfica para outra é uma atividade bastante comum em várias partes do mundo devido às atividades de criação e pesca esportiva (WELCOMME, 1988). Aproximadamente $17 \%$ da produção mundial de peixes são de espécies exóticas, este número mostra a importância do uso de espécies fora de seu local de ocorrência para a economia de muitos países. Como exemplo, podemos citar a produção de salmão no Chile que é responsável por $20 \%$ do total da produção mundial de salmão e emprega diretamente cerca de 30.000 pessoas (FAO, 20052012).

Os impactos causados pela introdução ou mesmo translocação entre bacias tem sido um tema de bastante controvérsia. Se por um lado a introdução de espécies possibilitou o desenvolvimento econômico de um país e ou região (DE LONGH; VAN ZON, 1993), por outro gerou problemas ambientais, tais como predação, competição com espécies nativas, modificação de ambientes e introdução de patógenos tem sido algumas das possíveis consequências da introdução ou translocação de espécies de peixes em águas continentais (ALVES et al., 2007).

A presença de híbridos na estatística de produção mostra o bom resultado zootécnico do processo de hibridização como método de melhoramento genético entre espécies nativas na piscicultura nacional, porém, levanta sérias preocupações sobre o escape destes híbridos e suas consequências sobre os recursos genéticos selvagens (ALLENDORF et al., 2001). A produção de híbridos para piscicultura no Brasil remonta de 1985, quando dos primeiros experimentos com cruzamentos entre espécies dos gêneros Colossoma e Piaractusforam realizados CEPTA/ICMBio (TOLEDO-FILHO et al., 1994). A produção de híbridos com espécies nativas se expandiu e atualmente corresponde a $6,7 \%$ da produção nacional de peixes cultivados com 17 tipos de híbridos entre espécies e até gêneros diferentes (PORTOFORESTI et al., 2010). 
As consequências sobre os recursos genéticos nativos, tais como introgressão genética com populações selvagens, vantagem competitiva representada pelo vigor de híbrido entre outros podem levar a erosão da variabilidade genética representada por populações geograficamente estabelecidas (HASHIMOTO et al., 2012).

Em relação à conservação dos recursos genéticos, não podemos deixar de lado as ameaças representadas pela fragmentação e por que não dizer da destruição de ecossistemas aquáticos devido ao crescente aumento das demandas para o desenvolvimento econômico. As condições hidrogeográficas no Brasil são propícias para geração de energia via hidroeletricidade. De acordo com a Agência Nacional de Energia Elétrica (ANEEL, 2008), $77 \%$ da produção anual de eletricidade são fornecidas por hidrelétricas. São 158 usinas hidrelétricas de grande porte que produzem juntas 74.438.695 KW (Agência Internacional de Energia, 2003). Esta opção traz consigo uma série de impactos ambientais (JUNK et al., 1990), dentre estes impactos qualitativos e quantitativos sobre as comunidades e populações de peixes (CAROLSFELD et al., 2003).

A primeira parte deste trabalho descreveu e introduziu a importância dos recursos genéticos para segurança alimentar das futuras gerações. Especificamente, a ictiofauna de água doce, ainda hoje fonte de sustento para milhões de habitantes neste planeta, tem sido alvo de ameaças diversas principalmente de natureza antrópica (PULLIN; CASAL, 1996). O potencial de utilização de espécies de peixes nativos do Brasil para produção de alimentos e outras riquezas associadas depende do conhecimento e conservação destes assim chamados recursos genéticos. Estimativas confiáveis da biodiversidade em todos os níveis de complexidade são extremamente difíceis de alcançar. Para se conseguir efetivamente tais estimativas, uma abordagem a qual informações do habitat e diversidade de espécies sejam integradas com informações sobre sistemática e principalmente genética de populações se faz necessária (BEARDMORE et al., 1997). 


\section{Capítulo II - Caracterização dos recursos genéticos}

\subsection{Entendendo a estrutura genética de populações}

Os recursos genéticos em sua definição utilitária podem ser considerados como um dos primeiros recursos biológicos para manutenção sustentável para produção de alimentos, e outras riquezas para o homem. As informações genéticas contidas nos genes e outras regiões reguladoras do DNA é o que aproxima e diferencia todas as espécies do planeta terra.

A conservação desta vasta diversidade de vida, ainda em processo de descoberta, tem sido foco de crescente atenção nas últimas décadas por parte de diversos setores da sociedade que tem alertado para o perigo das políticas desenvolvimentistas em detrimento do meio ambiente e consequentemente dos seres que o habitam. Contudo, recursos genéticos podem ser também entendidos, não somente pela diversidade de espécies, mas também pelas diferenças encontradas entre populações de espécies ou mesmos raças e variedades em animais e plantas domesticadas, respectivamente.

A diferenciação populacional de uma dada espécie é naturalmente determinada por processos evolutivos, tais como seleção natural, fluxo gênico, deriva genética, mutação e o tempo para que estes processos ocorram (CHAKRANORTY; LEIMAR, 1987). Entender a estrutura genética de populações de uma espécie na natureza é elucidar os processos que levaram e levam a conectividade entre diferentes populações. Desta forma, determinar o conceito de população é pivotal para as áreas da ecologia, biologia evolucionária, conservação e produção de alimentos. Vários são os conceitos e definições sobre populações que podem ser encontradas na literatura nos diversos campos de conhecimento (WAPLES; GAGGIOTTI, 2006).

Devido à importância da diferenciação populacional para uma espécie na natureza, o estabelecimento de uma conceito mais objetivo de populações e a padronização das medidas de suas similaridades e diferenças faz-se necessário.

Uma abrangente definição de populações foi proposta por Ihssen et al. (1981), que descreveram uma população local como "um grupo intraespecífico de indivíduos que se reproduz ao acaso com integridade espacial e temporal”. O interesse pela variação genética em populações já era assunto de interesse mesmo sem o conhecimento da proposta de transmissão de caracteres hereditários proposta por Mendel em 1865.

Francis Galton foi o pioneiro na aplicação de métodos estatísticos para estudar características humanas, tais como cor dos olhos, temperamento, habilidades intelectuais entre outras e que levou a criar uma escola de "geneticistas" chamados de Biometristas. 
A base teórica do que conhecemos como genética de populações foi estabelecida por Castle (1903), Hardy (1908) e Weinberg (1908). Os princípios atualmente utilizados nos estudos de genética populacional foram estabelecidos principalmente por Hardy e Weinberg e tornou-se conhecido como Equilíbrio de Hardy-Weinberg (EHW), que de forma geral descreve as modificações nas frequências gênicas e alélicas de uma população ao longo das gerações. $\mathrm{O}$ princípio proposto por Hardy-Weinberg estabelece que as proporções dos genótipos, isto é, as frequências gênicas permanecem constantes em uma população infinitamente grande e panmítica na ausência de mutação, seleção natural, migração, deriva genética. Estas condições são difíceis de ocorrerem na natureza, assim, ao se medir as proporções dos genótipos observados em uma população natural, é possível se calcular as frequências gênicas e alélicas desta mesma população se estivessem no equilíbrio. As diferenças encontradas podem ser explicadas por um dos processos evolutivos que atuam sobre a população (Figura 7).

A
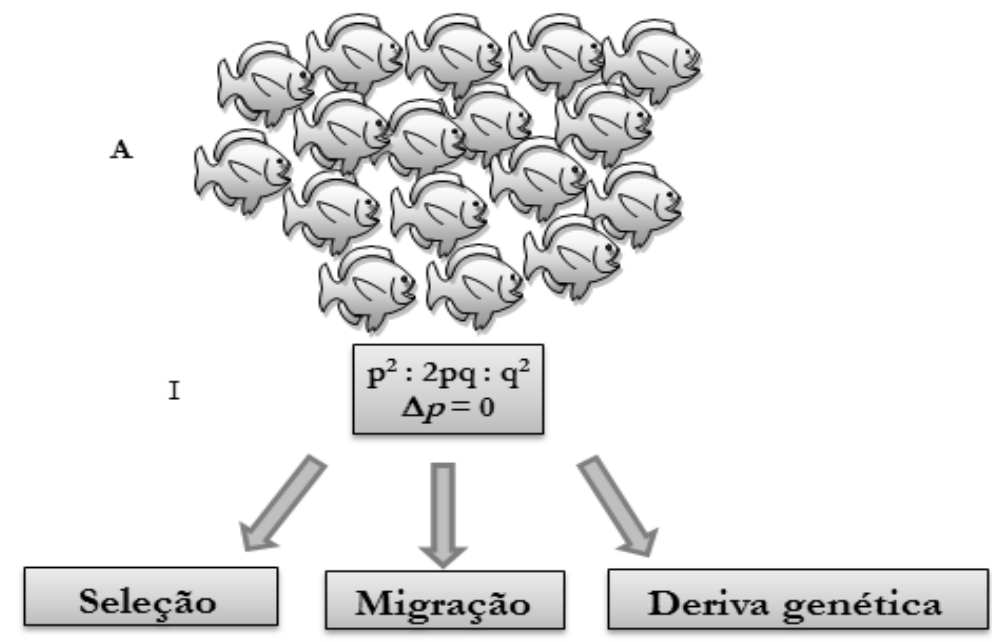

\section{II}

III
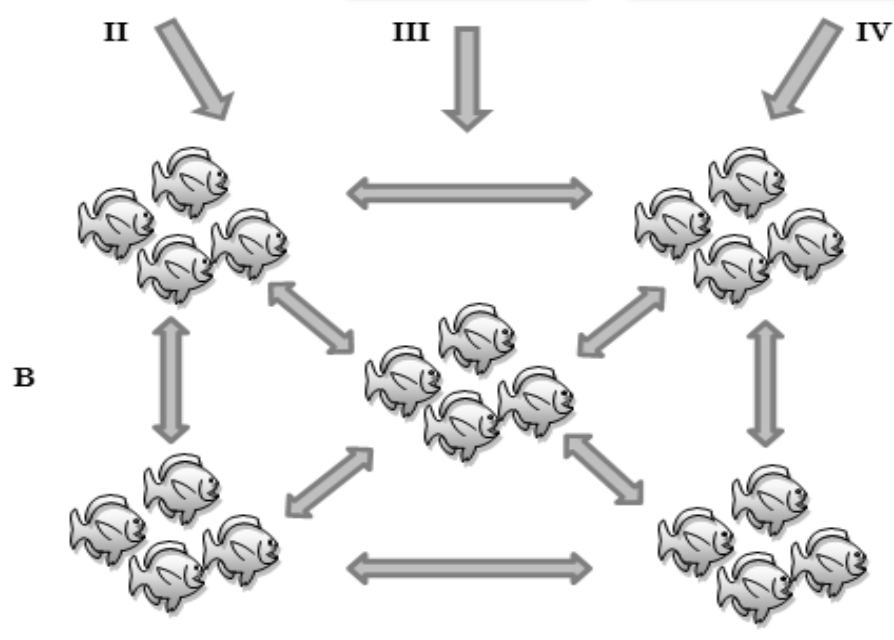
Figura 7. Modelo básico da genética de populações: (A) população panmítica infinitamente grande permanece estável $(\Delta p=0)$ na ausência de seleção, migração, e deriva genética de acordo com a lei de Hardy-Weinberg expressa pela fórmula I. Os números II, III e IV são as principais forças responsáveis pelas mudanças nas frequências gênicas $(\Delta p=0)$. (B) representa uma população subdividida formada pela ação simultânea de seleção, migração e deriva genética que pode levar a estruturação populacional. (adaptado de ALTUKHOV, 1981).

$\mathrm{Na}$ natureza, a ausência de estruturação genética populacional é chamada de panmixia. Quando eventos evolutivos ocorrem, tais como: (i) novas mutações que podem se propagar dentro de um grupo de indivíduos, efeito fundador por migrações seguidas de isolamento geográfico o que refletirá novas frequências alélicas baseadas na população fundadora, (ii) deriva genética que é processo microevolutivo que modifica as frequências alélicas de uma população; novas populações podem surgir. A subdivisão populacional pode ocorrer pelo isolamento de uma população (efeito fundador), levando ao aumento da endogamia. Nesta nova população, novas frequências alélicas serão estabelecidas e submetidas à seleção, em diferentes momentos da história evolutiva da nova população (efeito gargalo). Na deriva genética, a população passa por um estrangulamento ou efeito gargalo (redução do número de indivíduos da população) causado por algum fenômeno natural ou não.

A fixação ou não das novas frequências alélicas determinadas estocasticamente ao longo do tempo é função da interação dos fenômenos de levam a deriva genética e os efeitos da seleção natural sobre as populações. É importante salientar que os efeitos da deriva genética sobre as populações estão diretamente relacionados ao tamanho da população sendo seu efeito maior em populações pequenas.

Um modelo simples de diferenciação contínua de populações foi proposto por Waples e Gaggiotti, (2006) (Figura 8). Neste modelo cada circulo pode ou não representar populações diferentes, sendo que dentro de cada população o cruzamento é aleatório e as populações podem estar ligadas variando o grau de conectividade (sobreposição geográfica e/ou migração). A manutenção da conectividade genética que mantém uma metapopulação é o fluxo gênico. Assim, a metapopulação é um conjunto de populações locais ou não que interagem por fluxo gênico com eventos de extinções e recolonizações. 


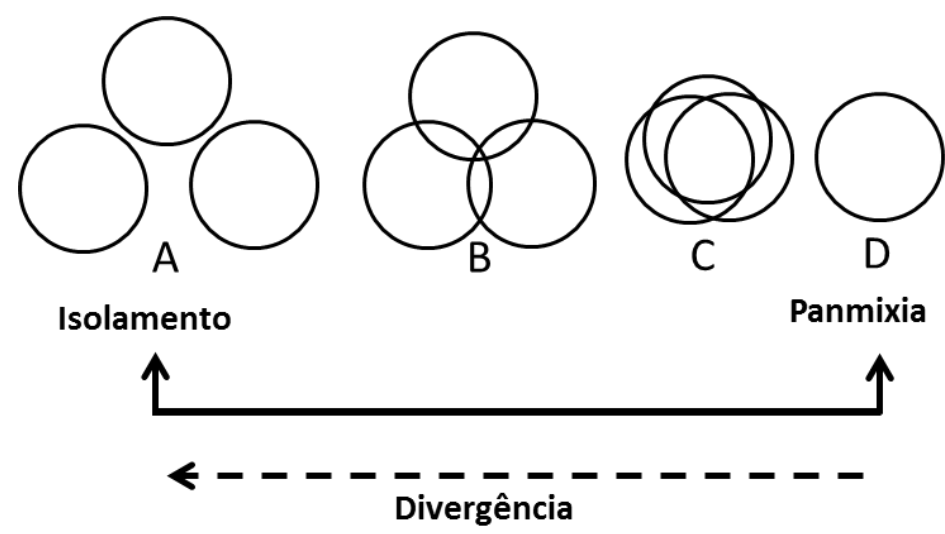

Figura 8. Modelo simples de diferenciação contínua de populações.

(A) Independência completa. (B) Pequena conectividade. (C) Significativa conectividade. (D) Panmixia, as populações estão totalmente congruente.

As espécies na natureza não são homogêneas, mas sim em maior ou menor grau estruturadas em populações. De acordo com o tipo de dispersão da espécie há três tipos de modelos de estruturação genética de populações:

i) Isolamento por distância (Isolation by Distance): descreve a tendência de que populações que estão mais próximas sejam mais similares geneticamente do que aquelas mais distantes. Espécies sob o modelo de isolamento por distância são mais ou menos diferentes dependendo do grau de dispersão da espécie em relação às distâncias geográficas na área de ocupação das populações. É importante salientar que tais populações não estão em panmixia, contudo a delimitação das populações é sútil. O efeito é uma contínua perda de parentesco à medida que as distâncias geográficas aumentam (WRIGHT, 1978).

ii) Modelo de ilhas infinito (Infinite Island Model) : é o modelo convencional de estruturação populacional. Neste modelo, a diferenciação entre as populações não depende da distância entre elas. Neste modelo há um equilíbrio entre a deriva genética e migração entre todas as populações, sendo que os indivíduos podem ser provenientes de uma população de tamanho infinito ou de outras ilhas. O Modelo de Continente-Ilha (Figura 9) descreve uma população continental infinitamente grande com cruzamento aleatório e uma população insular de tamanho Ne em que há um constante número de migrantes $(M)$ da área continental à insular a cada geração. No caso do Modelo de Ilhas Simétricas (Figura 10) há um padrão de várias ilhas ou 
populações conectadas por migração, a cada geração as populações trocam migrantes em similares quantidades (WRIGHT, 1978).

iii) Modelo passo-a-passo (Stepping Stone Model): as populações ocorrem de forma descontinua na natureza e geralmente diferem em tamanho. Em muitos casos a taxa de migração é maior entre populações próximas do que entre populações mais distantes. Para organismos com baixas taxas efetivas de dispersão, as populações tendem a trocar migrantes entre aquelas mais próximas (KIMURA, 1953). Dois tipos do modelo passo-a-passo podem ser encontrados, o modelo linear que é comum em espécies distribuídas em habitats lineares (regiões estuarinas, por exemplo) (Figura 11) e o modelo bi-dimensional (Figura 12) que pode ser comparado com a distribuição de oásis em um deserto, isto é, a correlação das frequências gênicas entre populações diminui exponencialmente em função da distância (passos) entres as populações (KIMURA AND WEISS, 1964).
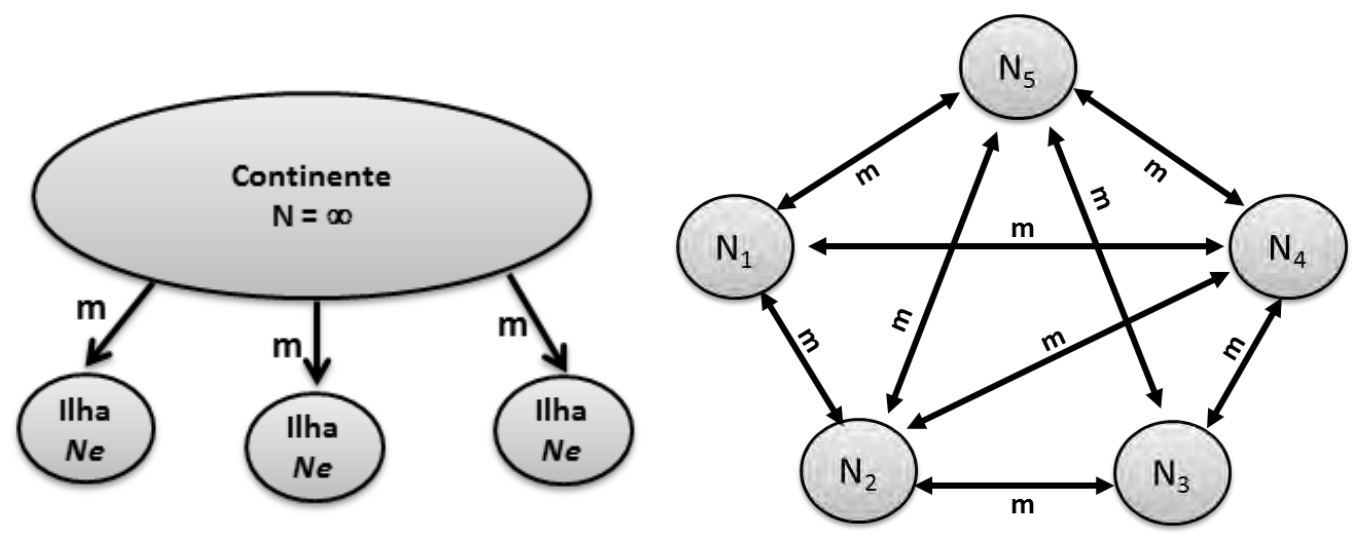

Figura 9: Modelo de Continente-Ilha Figura 10: Modelo de Ilhas Simétricas

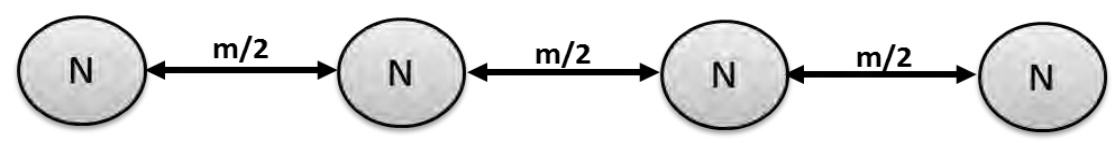

Figura 11: Modelo passo-a-passo linear

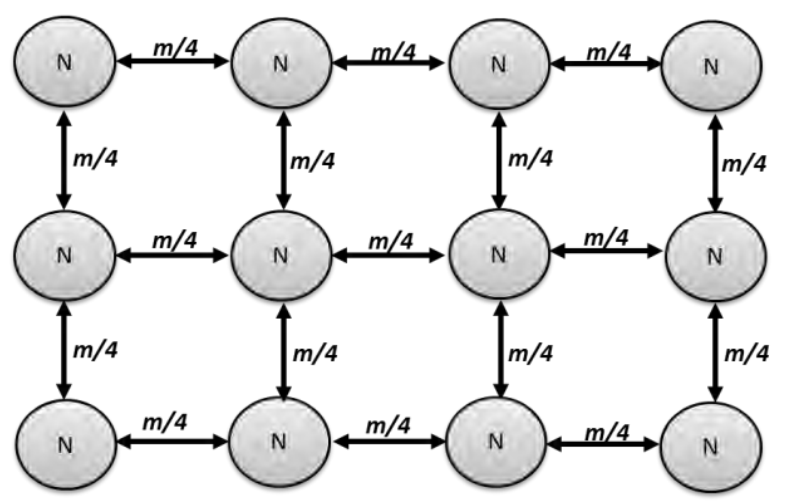

Figura 12: Modelo passo-a-passo bi-dimensional 


\subsection{O conceito de populações para o manejo pesqueiro}

O conhecimento das diferenças genéticas dentro e entre populações naturais, raças, variedades ou linhagens de espécies de interesse econômico em cativeiro é a base para a manutenção da variabilidade genética. Sua manutenção é um importante requerimento para conservação dos estoques de peixes explotados pela pesca, bem como para as estratégias de melhoramento genético de espécies domesticadas que são constantementes submetidas a mudanças ambientais provocadas pelo manejo.

Tanto para ecologia como para a genética de populações, várias são as terminologias para designar as comunidades animais intraespecíficas. Na literatura pode ser encontrados termos, tais como população, subpopulações, população mendeliana, deme, raça, estoque, entre outras. Seja qual for o termo utilizado, o conceito de populações locais, subpopulações, estoques ou demes (DIZON et al., 1992) pode diferir dependendo do grau de homogeneidade genética encontrada, da importância quanto ao isolamento reprodutivo e ao potencial de explotação (GULLAND, 1969; SMITH et al., 1990). No caso de recursos pesqueiros, o conceito de população local se complica ainda mais por fatores políticos, econômicos e sociais.

De acordo com Carvalho e Hauser (1994), a conceituação de estoques abrange uma ampla gama de definições dependendo de quem as propõe e para que propósito. Por exemplo, em termos práticos, para aqueles que manejam estoques pesqueiros para fins comerciais, o estoque pode ser considerado como um grupo de peixes explotados em uma área específica ou por um método de captura específico. Aspectos políticos e socioculturais também podem influenciar na definição de um estoque, pois a pesca comercial nem sempre leva em consideração os benefícios de sua preservação em longo prazo, devido à pressão pela ampliação de cotas por novos recursos e locais de captura (Figura 13). Estoque pesqueiro é, portanto, um grupo de peixes da mesma espécie, o qual habita uma mesma área e que estão dentro da faixa etária (ou de tamanho) permitida para serem pescados. Sendo, assim, a captura indiscriminada de um estoque pesqueiro pode comprometer diferentes populações genéticas de uma mesma espécie.

O conceito de população proposta por Ihssen et al. (1981) - um grupo intraespecífico de indivíduos que se reproduz ao acaso com integridade espacial e temporal - não é usualmente aplicado na explotação dos estoques pesqueiros, pois nesta situação as diferenças genéticas e fenotípicas entre as populações não são levadas em consideração. Marr (1957) propôs uma diferenciação ente populações ou estoques, este autor define estoque da seguinte forma:

"Um estoque é uma população ou uma subpopulação no qual todos os membros são caracterizados por similaridades que não sejam herdáveis, mas induzidas pelo ambiente. Um estoque pode ou não incluir membros de diferentes subpopulações”. 
Assim, neste caso, estoques são de interesse direto daqueles que os utilizam na pesca e que estão interessados em peixes que apresentem similaridades fenotípicas, tais como taxa de crescimento, fecundidades, taxas de recrutamento e mortalidade; mesmo que tais estoques sejam compostos por populações geneticamente distintas. Já o conceito populacional, dentro de um ponto de vista genético, atribui a tal unidade biológica um alto grau de integridade que leva em consideração o isolamento reprodutivo, diferenciação genética de outras populações, especialização ecológica e adaptação local (BEGG et al., 1999).

Desta forma, o conceito de população descrito por Ihssen et al. (1981) pode ser interpretado de acordo com o manejo a ser implantado, aqui especificamente, sobre um recurso biológico aquático. Por um lado, temos uma estratégia em curto prazo, cuja preocupação básica é a manutenção do recurso, evitando sua redução pelo excesso de captura; por outro, temos uma estratégia de conservação em longo prazo, que leva em consideração a diversidade genética dentro e entre populações.

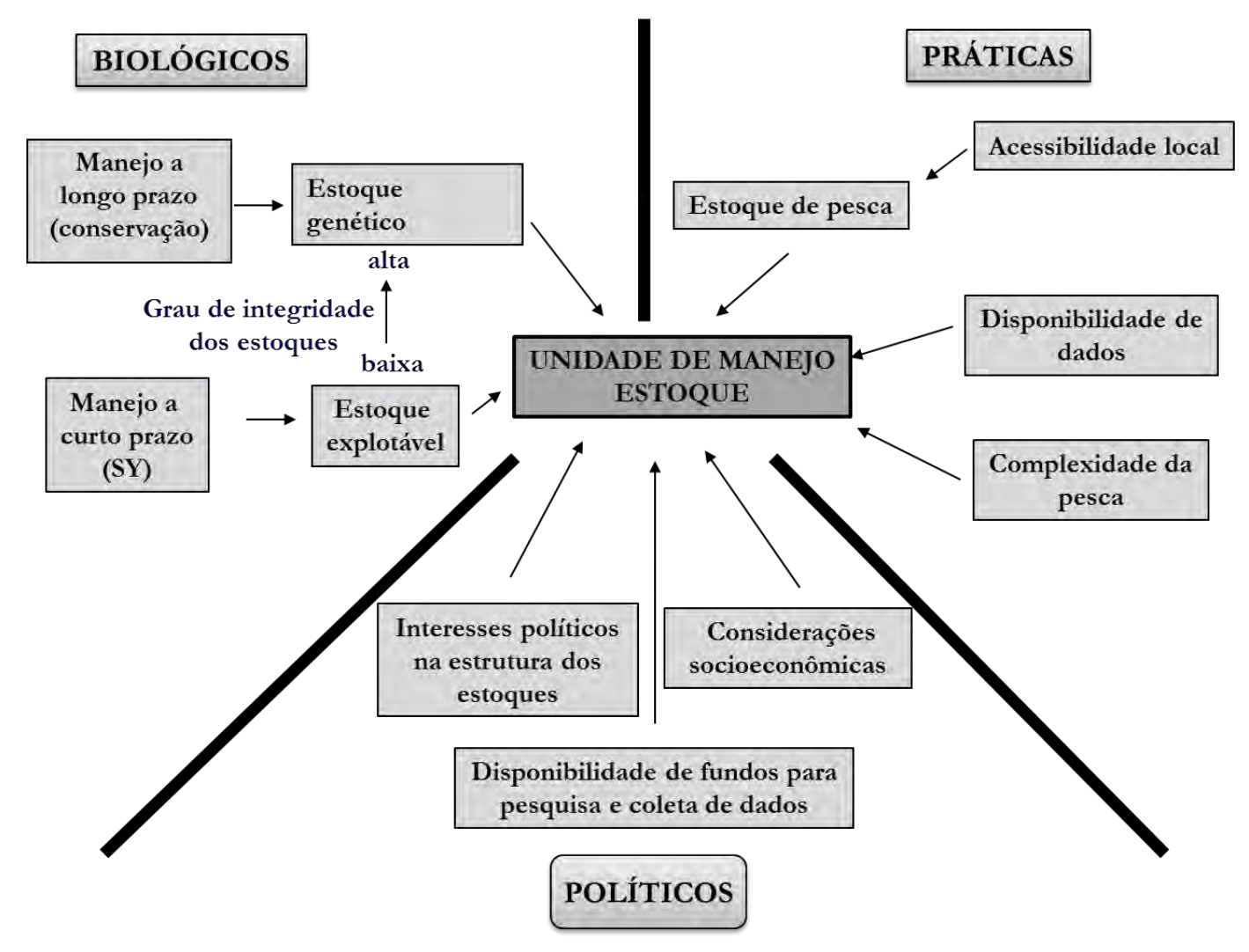

Figura 13. Representação dos fatores que afetam o conceito de "Estoque" para o manejo pesqueiro. Fonte: Carvalho e Hauser (1994). 


\subsection{Variação genética e sua importância para a domesticação e melhoramento de peixes.}

Ambientes aquáticos sejam de águas continentais, marinhas ou salobras são altamente variáveis no espaço e no tempo e são sujeitos a diversas perturbações antrópicas. Variações na temperatura, pH, concentração de íons, salinidade, redução de DBO (disponibilidade biológica de oxigênio) entre outras são comuns em ambientes aquáticos e são consideradas como fatores de estresse abióticos que levam a respostas fisiológicas das populações locais. Estas oscilações ambientais são ainda mais pronunciadas em sistemas aquáticos localizados na região neotropical. Por exemplo, a região do Pantanal do Mato Grosso apresenta um processo anual ou multianual de enchente/cheia que inunda grande parte do Pantanal (JUNK; CUNHA, 2005). Este pulso de inundação, como é conhecido cientificamente, modifica o ambiente consideravelmente e afeta as populações de peixes de várias formas e intensidades (DA SILVA, 2000). Outro exemplo corre em lagos da bacia Amazônica; nestes locais a disponibilidade de oxigênio pode variar de zero durante a noite a níveis de saturação durante o dia. Estas variações de oxigênio geram respostas fisiológicas importantes nos ajustes de espécies de peixes a estas condições extremas de oxigênio (VAL; ALMEIDA-VAL, 1999).

A habilidade de produzir diferentes fenótipos sob diferentes condições ambientais é conhecida como plasticidade fenotípica (PIGLIUCCI, 1996). A plasticidade fenotípica em diferentes animais e plantas, aqui especificamente em peixes, mostra a interface que existe entre a variação genética em populações naturais e as repostas fisiológicas frente aos estímulos ambientais (WALKER, 1997). Vários são os estudos que demonstram a adaptação de peixes amazônicos às variações ambientais (ALMEIDA-VAL et al., 1993; VAL et al., 1998).

A adaptabilidade relativa ou valor adaptativo (fitness) é uma medida importante da plasticidade fenotípica. Este conceito é o resultado das relações entre os genótipos e os fatores ambientais que produzem fenótipos mais ou menos adaptados. Assim, diversidade genética intra e interpopulacional é um fator chave para que novos fenótipos sejam produzidos. Neste ponto, a heterozigosidade e o valor adaptativo de uma população se encontram. A existência da relação entre heterozigosidade e valor adaptativo foi demonstrada por uma meta-análise que mostrou uma relação significativa que explica que $19 \%$ da variação genética é devido ao valor adaptativo (REED; FRANKHAM, 2003).

Características genéticas quantitativas, as quais são controladas por vários genes e cuja expressão do fenótipo apresenta pronunciada influência ambiental estão geralmente correlacionadas ao número de lócus em heterozigose. (MITTON; GRANT, 1984; ALLENDORF; LEARY, 1986). A relação entre heterozigosidade para lócus aloenzimáticos e valor adaptativo de características como viabilidade, resistência a doenças, taxa de crescimento, 
fecundidade, eficiência fisiológica foi revisada para peixes do grupo dos salmonídeos (WANG et al., 2002). Este estudo mostrou que as correlações entre heterozigosidade e valor adaptativo variam, e apesar de no geral esta correlação ser tênue, existem características sobre as quais correlações positivas foram encontradas. Esta abordagem não tem sido muito explorada para espécies de peixes neotropicais, que por estarem sujeitos a ambientes de variações extremas podem ser um modelo adequado para um melhor entendimento entre heterozigosidade e valor adaptativo.

O conhecimento das diferenças inatas entre peixes de diferentes populações genéticas como resultados dos processos evolutivos é uma etapa importante em programas de conservação de populações selvagens e em melhoramento genético. Respostas a fatores de estresse em peixes, tais como assimilação de oxigênio dissolvido, mobilização de energia para os processos fisiológicos, supressão de fatores imunológicos entre outros são bem conhecidas, principalmente em peixes que vivem em ambientes naturais desfavoráveis ou em ambientes de cultivo (BONGA, 1997; VANDEPUTTE; PRUNET, 2002). Padrões de expressão de genes relacionados às respostas a condições de estresse podem diferir em peixes de populações geneticamente diferentes (IWAMA et al., 1992; POTTINGER; CARRICK, 1999; PICARD; SCHULTE, 2004).

A evidência de que existem mecanismos genéticos de adaptação fisiológica de populações a diferentes habitats é importante para se entender a variação na expressão de genes entre populações, e como estes genes auxiliam na adaptação a novos ambientes. Em peixes de água doce de ambientes neotropicais os processos de isolamento geográfico fazem com que algumas espécies de ampla distribuição tenham que se adaptar a condições ambientais diferentes. Especificamente, o pintado ou surubim (Pseudoplatystoma corruscans) é um bom exemplo de como o conhecimento das diferenças genético populacionais é o primeiro passo para se entender as variações adaptativas que podem ser usadas em programas de melhoramento.

O pintado ocorre na bacia do rio São Francisco, Paraná, Paraguai e Uruguai. Esta ampla distribuição desde regiões de latitudes menores mais quentes até regiões de latitudes maiores mais frias (SATO et. al., 2006; BRITSKI et. al., 2007; ZANIBONI FILHO; SCHULZ, 2003) faz com que possivelmente as populações de pintado mais ao sul (Rio Uruguai) apresentem adaptações locais diferentes das populações do Rio São Francisco, por exemplo. Benites (2008) estudou a diferenciação genética populacional de pintado coletados em rios da bacia do Paraguai no Pantanal Mato-Grossense e em rios da bacia do Alto Paraná por meio de marcadores microssatélites. Os resultados mostraram significativa estruturação genética mesmo entre peixes da mesma bacia com valores de $\mathrm{F}_{S T}=0,12(p<0,05)$. A diferenciação genética entre populações de rios da bacia do Alto Paraguai é de certa forma uma surpresa, visto que outros estudos com 
populações de outras espécies mostram que devido ao fenômeno das cheias no Pantanal as populações de peixes tendem a se misturar reduzindo a diferenciação genética entre estas populações (IERVOLINO et al., 2010; OKASAKI, 2013). Sendo assim, as diferenças encontradas entre populações de pintado dentro de uma mesma bacia podem ser ainda maiores se compararmos as populações do rio Uruguai com as demais populações encontradas em bacias mais ao norte. Contudo, o que pode significar estas diferenças para programas de melhoramento genético?

A base de qualquer programa de melhoramento genético reside nas diferenças de caracteres herdáveis encontradas principalmente entre populações. A conservação da integridade genética destas populações é, então, um objetivo a ser alcançado para o sucesso de um programa de melhoramento genético. Bancos de germoplasma in-situ e ex-situ de espécies de interesse na alimentação humana têm sido implantados ao redor do mundo como uma estratégia para conservar a diversidade gerada ao longo do tempo pelos processos evolutivos (MARIANTE et al., 2009).

Ao contrário de espécie de animais terrestres, poucas são as espécies de peixes que passaram por programas de melhoramento (BARTLEY, 1998; GJEDREM, 1992; BENTSEN et al., 1998). No caso de espécies de peixes neotropicais, poucas as espécies têm sido submetidas a programas dirigidos de seleção para obtenção de variedades intraespecíficas melhoradas geneticamente. O que se tem feito é a prática de produção de híbridos interespecíficos para obtenção rápida de respostas a condições de cultivo. (REIS-NETO et al., 2012).

Sendo assim, a caracterização das populações selvagens de uma espécie de peixe alvo para um programa de melhoramento é uma etapa fundamental para se verificar se as diferenças genéticas encontradas por meio de marcadores bioquímicos ou moleculares são encontradas também nos processos fisiológicos adaptativos (HOLTSMARK et al., 2008). Além disto, esta caracterização tem um caráter estratégico, pois de acordo com a Convenção Internacional de Direitos de Recursos Genéticos (JARAMILLO; BAENA, 2000) os direitos sobre os recursos genéticos de um país passam pela devida avaliação e caracterização destes recursos.

Em relação ao pintado, a seguinte questão pode ser levantada: será que as populações de pintado residentes no Rio Uruguai, ou mesmo, mais ao sul na Argentina são mais adaptadas a temperaturas mais baixas, e esta característica quando adequadamente avaliada pode ser incorporada em programas de melhoramento para obtenção de uma variedade de pintado resistente a regiões mais frias? O exemplo do pintado é um entre as diversas espécies nativas de peixes do Brasil e outros países da América do Sul que pode apresentar em um primeiro momento características não adequadas ao cativeiro e ao cultivo, porém, a diversidade genética 
encontrada na natureza pode ser o que os melhoristas necessitam para o estabelecimento de programas de melhoramento genético (BASAVARAJU et al., 2002).

As variações genéticas existentes entre populações que podem indicar níveis de isolamento genético e são evidenciadas por marcas presentes no longo do genoma mitocondrial e nuclear. $\mathrm{O}$ isolamento leva a mudanças nas frequências gênicas de populações, e ao acúmulo de novas mutações que não são compartilhadas pelo processo de fluxo gênico. Ao se medir o grau de diferenciação genética entre populações, na verdade estamos indiretamente revelando a possível variabilidade genética em lócus que estejam envolvidos em fenótipos relacionados a processos adaptativos.

A variabilidade genética importante para a sobrevivência a longo prazo das populações selvagens, é também fundamental para a manutenção dos recursos genéticos mantidos em cativeiro em escala familiar por comunidades humanas isoladas. Estas populações em cativeiro são submetidas à intensa seleção geração após geração através dos tempos para que tolerem e se adaptem as condições ambientais locais. Entre vários exemplos, podemos citar comunidades no Vietnam que criam uma carpa nativa em consórcio com cultivo de arroz. As carpas utilizadas têm sido submetidas a gerações de seleção que as tornam valiosas para as comunidades locais, pois são adaptadas as condições ambientais e de manejo, como por exemplo, não deixarem os campos de arroz quando das periódicas inundações (EDWARDS et al., 2000). A introdução de outra população, mesmo com melhores características genéticas para crescimento pode levar ao desparecimento um recurso genético local importante gerado após vários anos de seleção.

Outro exemplo foi o programa GIFT (Genetic Improvement of Farmed Tilapia), este programa foi um esforço internacional coordenado pela então ICLARM (atualmente World Fish Center) nos anos de 1988 a 1997 (EKNATH, 1992; EKNATH; ACOSTA, 1998). A GIFT atualmente utilizada em várias parte do mundo, inclusive no Brasil (SCORVO FILHO et al., 2010) é uma tilápia nilótica (Oreochromis niloticus) que foi desenvolvida a partir da coleta de populações locais utilizadas por comunidades em diferentes países e selvagens. Oito populações foram usadas em um programa de cruzamento dialélico e 64 cruzamentos geraram populações puras e cruzamentos inter-populacionais recíprocos que foram avaliados por testes em diferentes ambientes e sistemas de manejo (EKNATH et al., 1993; EKNATH et al., 2007). Os impactos da GIFT no tilapicultura em várias partes do mundo são diversos e foram elencados por Eknath e Hulata (2009). 


\subsection{Os marcadores moleculares usados na caracterização de populações de peixes.}

O uso de caracteres fenotípicos sejam eles induzidos ou não pelo ambiente para distinguir populações ou mesmos indivíduos foi e ainda tem sido a classe de marcadores mais utilizados para o manejo de populações de peixes no meio ambiente, como também a base para programas de melhoramento genético de animais domésticos. Trabalhos publicados nas décadas de 1940 (MCHUGH, 1942) e de 1950 (ROYCE, 1957) já demonstravam a utilidade de características morfológicas na delimitação de populações de peixes para fins de manejo pesqueiro.

O desenvolvimento dos princípios da eletroforese pelo prêmio Nobel de química de 1948, bioquímico sueco Arne Wilhelm Kaurin Tiselius, em seu famoso "Tiseliusapparatus" (TISELIUS, 1937) abriu novas perspectivas de separação de moléculas. Novos métodos baseados em matrizes sólidas possibilitaram a separação de moléculas carregadas eletricamente em bandas. A assim chamada Eletroforese de Zona. Em 1955, foi introduzido o gel de amido como meio de corrida para proteínas (SMITHIES, 1955), e em 1957 foi desenvolvido a técnica histoquímica para corar proteínas e visualizar aloenzimas e isoenzimas (HUNTER; MARKERT, 1957), o que possibilitou o aprimoramento de técnicas que permitiram separar uma mistura de proteínas provenientes de um tecido qualquer e avaliar diferenças entre elas observando-se diretamente o padrão de bandas em um gel de amido.

A primeira classe de marcadores baseados em variantes protéicas foram as chamadas aloenzimas. Este termo surgiu da frase Allelic V ariants of Ensymes (SCHLÖTTERER, 2004) e são enzimas codificadas por diferentes alelos de um mesmo loco, ao contrário das isozenzimas que são enzimas que cumprem a mesma função, contudo são codificadas por genes localizados em lócus diferentes. Na década de 1960, estudos sobre variantes protéicas em humanos (HARRIS, 1966) e drosophilas (HUBBY; LEWONTIN, 1966; JOHNSON et al., 1966) começaram a ser publicados. Em artigo de 1957, Marr propõem o uso de "características sanguíneas" para separar populações genéticas de peixes em populações similares fenotipicamentes, este princípio foi a base para o uso de variantes alélicas de proteínas sanguíneas na nascente técnica de eletroforese em matriz sólida (CUSHING, 1956; SHAW; PRASAD, 1970; BREWER, 1970).

A eletroforese de proteína dominou os estudos de genética populacional de peixes nas décadas de 1960 e 1970 (WHITMORE, 1990). Os primeiros trabalhos para identificar grupos sanguíneos em peixes foram publicados na década de 1950 (CUSHING, 1952; 1956). Com a demonstração do polimorfismo presente em proteínas sanguíneas, a eletroforese de variantes sanguíneas logo começou a ser usada em estudos genéticos populacionais de peixes marinhos (RIDGWAY et al., 1958; SUZUKI, 1962; ALTUKHOV et al., 1969, FUGINO 1970, UTTER et al., 1974). 
A partir da década de 1980, inicia-se uma mudança no uso de marcadores moleculares para investigar a variabilidade genética dentro e entre populações. A revolução que se avistava desde a descoberta das enzimas de restrição pelos cientistas Werner Arber, Hamilton O. Smith e Daniel Nathans na década de 1970 possibilitou o estudo das variações mutacionais diretamente, já que o uso de proteínas era uma forma indireta de verificar o polimorfismo contido na fonte da variação - o DNA. Um segundo marco na universalização do uso de marcadores moleculares foi sem dúvida o desenvolvimento da técnica da reação em cadeia da polimerase Polymerase Chain Reaction- PCR (SAIKI et al., 1988). O sequenciamento automático do DNA veio como consequência da técnica da PCR, tornando a publicação de sequências do DNA uma atividade rotineira. Isto pode ser constatado pela quantidade de sequências disponibilizadas no GeneBank (National Center for Biotechnology Information - http://www.ncbi.nlm.nih.gov/) que de certa forma tem facilitado o uso da técnica da PCR em diversos táxons.

Estes avanços tecnológicos no que se convencionou chamar de Tecnologia do DNA Recombinante pavimentaram um caminho sem retorno em direção ao desenvolvimento de diferentes tipos de marcadores baseados na variabilidade encontrada no DNA (PARK; MORAN, 1994; VIGNAL et al., 2002; OKUMUS; ÇIFTCI, 2003; SCHLÖTTERER, 2004; FINGER; KLANK, 2010). Um detalhamento técnico do uso dos marcadores moleculares, suas aplicações em estudos genéticos e os protocolos laboratoriais utilizados estão amplamente revisados por Ferreira e Grattapaglia, (1998).

Ao longo dos anos 1980 e 1990 com o aprimoramento das técnicas de PCR e sequenciamento diversas classes de marcadores forma sendo desenvolvida para explorar e evidenciar de maneira rápida e se possível barata a variação contida na molécula de DNA. Com isto, os marcadores foram sendo popularizados por acrônimos. Uma lista dos principais acrônimos de marcadores moleculares está na tabela 2. 
Tabela 2. Lista de Acrônimos dos principais marcadores moleculares usados em estudos genéticos.

\begin{tabular}{|c|c|c|}
\hline Acrônimos & Marcador & Referências \\
\hline AFLP & Amplified Fragment Length Polymorphism & Vos et al. (1995) \\
\hline DAF & DNA Amplification Fingerprinting & $\begin{array}{l}\text { Caetano-Anolle e } \\
\text { Bassam (1993) }\end{array}$ \\
\hline DALP & Direct Amplitication of Length Polymorphism & $\begin{array}{l}\text { Desmarais et al. } \\
\text { (1998) }\end{array}$ \\
\hline IMP & Inter-MITE Polymorphism & Chang et al. (2001) \\
\hline IRAP/REMAP & $\begin{array}{c}\text { Inter-RetrotransposonAmplified Polymorphism } \\
\text { REtrotransposon-Microsatellite Amplified } \\
\text { Polymorphism }\end{array}$ & $\begin{array}{l}\text { Kalendar et al. } \\
\text { (1999) }\end{array}$ \\
\hline RAMP & Randomly Amplified Microsatellite Polymorphisms & Wu; Tanksley (1993) \\
\hline RAP-PCR & RNA-fingerprinting by Arbitrarily Primed PCR & \\
\hline RAPD & Random Amplified Polymorphic DNA & $\begin{array}{l}\text { Williams et al. } \\
\text { (1990); Welsh e } \\
\text { McClelland (1990) }\end{array}$ \\
\hline RBIP & Retrotransposon-Based Insertion Polymorphism & Flavell et al. (1998) \\
\hline RFLP & Restriction Fragment Length Polymorphism & $\begin{array}{l}\text { Grodzieker et al. } \\
\text { (1974) }\end{array}$ \\
\hline SCAR & Sequence Characterized Amplified Region & $\begin{array}{l}\text { Paran e Michelmore } \\
\text { (1993) }\end{array}$ \\
\hline SNP & Single Nucleotide Polymorphism & $\begin{array}{l}\text { Sachidanandam et } \\
\text { al. (2001) }\end{array}$ \\
\hline SSCP & Single Strand Conformation Polymorphism & Orita et al. (1989) \\
\hline SRAP & Sequence-Related Amplified Polymorphism & Li e Quiros (2001) \\
\hline S-SAP & Sequence-Specific Amplification Polymorphism & \\
\hline $\begin{array}{c}\text { STR/SSR } \\
\text { Micro-Satélites }\end{array}$ & Short Tandem Repeat / Simple Sequence Repeat & $\begin{array}{l}\text { Litt e Luty (1989) e } \\
\text { Weber e May(1989) }\end{array}$ \\
\hline TRAP & Target Region Amplification Polymorphism & Hu e Vick (2003) \\
\hline $\begin{array}{c}\text { VNTR } \\
\text { Mini-Satélites }\end{array}$ & Variable Number Tandem Repeat & Jeffreyset al. (1985) \\
\hline
\end{tabular}

As técnicas citadas geralmente utilizam as informações contidas no genoma nuclear. Contudo, o polimorfismo encontrado no DNA mitocondrial devido suas características genéticas, tais como herança materna, genoma haplóide, ausência de recombinação, sensível aos efeitos da deriva genética e alta taxa evolutiva (BROWN, 1985) fizeram deste genoma uma excelente fonte de informações genéticas para estudos taxonômicos e populacionais (KOCHER et al., 1989; PALUMBI et al., 1991; MEYER, 1994).

As vantagens e desvantagens do uso dos marcadores moleculares em estudos genéticos e sua contribuição para questões que envolvem a conservação e manejo de estoques pesqueiros e aquicultura tem sido descritas em diferentes estudos (ALLENDORF et al., 1987; WARD; GREWE, 1994; FÉRAL, 2002; LIU; CORDES, 2004). Silva e Russo (2000), evidenciaram 1.291 artigos que utilizaram marcadores moleculares para abordar as seguintes questões: (i) análise da 
variação genética e identificação de indivíduos; (ii) análise da variação genética dentro de populações; (iii) análise da variação genética entre populações e (iv) análise da variação genética acima do nível de espécie. O que pode ser constatado foi que a grande maioria dos artigos utilizou a técnica do RFLP (44\%), seguida do RAPD (14\%), STR (8\%) e do VNTR (5\%). O sequenciamento foi utilizado por $18 \%$, principalmente para questões de sistemática molecular. No período levantado, a maioria dos artigos (54\%) utilizou o DNA mitocondrial como fonte de variação para os estudos genéticos. Na última década com o acesso mais amplo e a facilidade de se conseguir lócus microssatélites espécie-específicos ou mesmo por amplificação cruzada, os trabalhos de genética populacional migrou de forma consistente para o uso de marcadores STRs no genoma nuclear e para o uso mais intensivo de análise comparativa de sequências com o uso de regiões hipervariáveis do genoma mitocondrial, sendo que trabalhos com RFLP, RAPD, AFLP entre outros não tem sido evidenciado em publicações com recursos genéticos animais.

Um resumo das características dos marcadores moleculares usados em análises genéticas está apresentado na Tabela 3. 
Tabela 3. Tipos de marcadores moleculares, suas características e aplicação na avaliação genética de populações de peixes.

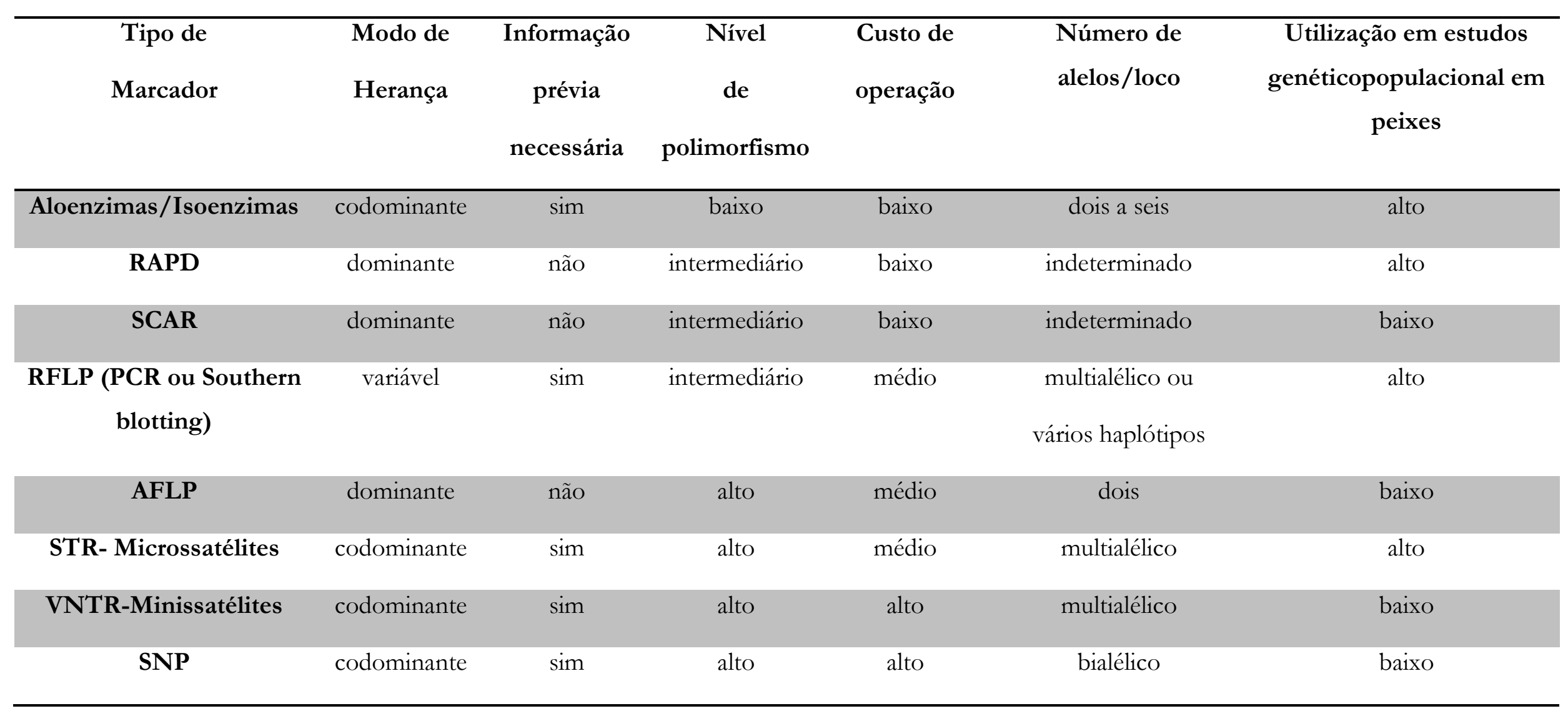




\subsection{Parâmetros de variabilidade genética intra e interpopulacional}

Diversidade genética é um dos parâmetros importantes recomendados pela IUCN para o manejo e conservação de espécies (MCNEELY et al., 1990). Segundo Reed e Frankham (2003), duas são a principais razões para se adotar medidas de manutenção da diversidade genética: (i) diversidade genética é essencial para que as populações evoluam em resposta as mudanças ambientais; (ii) níveis de heterozigosidade são diretamente ligados a adaptabilidade de uma espécie que pode ser reduzido pela depressão por endogamia.

De maneira geral e em particular para peixes de água doce, a determinação da existência de populações ou subpopulações isoladas por barreiras reprodutivas é a primeira etapa de um manejo conservacionista seja para manutenção de populações selvagens e sua sobrevivência, ou para seu manejo (no caso de peixes de interesse econômico) sustentável de maneira a evitar a sobrepesca de uma ou mais populações que possam compor um estoque pesqueiro, ou ainda para utilizar tal diversidade para compor uma população sintética para fins de melhoramento genético.

A seleção natural age temporalmente sobre populações e esta ação recai de forma geral sobre caracteres poligênicos que expressam fenótipos complexos relacionados à adaptabilidade das populações em condições ambientais variáveis. Contudo, a mensuração das mudanças genéticas para se avaliar o grau de diferenciação populacional é uma tarefa de difícil realização em populações selvagens. Como então, as possíveis diferenças genéticas entre populações que se diferenciam por barreiras reprodutivas podem ser quantitativamente medidas?

Embora muitos dos alelos estejam sob a ação de seleção, existem outros que têm pouca ou nenhuma influência sobre processos de adaptabilidade, estes alelos são chamados de Alelos Neutros (KIMURA, 1968). Os níveis de diversidade intra e interpopulacional, isto é, a modificação das frequências alélicas e genotípicas geradas pelo grau de conectividade (migração ou fluxo gênico) e deriva genética (que leva a divergência entre populações) podem ser revelados e mensurados pelos alelos neutros. Desta forma, o uso de marcadores moleculares que estejam situados em regiões genômicas não codificantes ou que sejam alelos alternativos seletivamente neutros pode refletir os níveis de conectividade genética entre populações, e como consequência as possíveis diferenciações adaptativas que as populações estão sendo submetidas (LARSEN et al., 2012). 


\subsubsection{Quantificação da diversidade genética intrapopulacional (baseado em Vicente et} al., 2004).

A medida da diversidade genética dentro de populações pode ser feita com base no número de variantes para cada um dos seguintes parâmetros: taxa de polimorfismo $(\mathrm{P} j)$, proporção de lócus polimórficos, riqueza alélica (A), número médio de alelos por lócus; ou com base na frequência de variantes: número efetivo de alelos (Ae) e heterozigosidade média esperada (He, diversidade genética de Nei).

\section{i) Polimorfismo ou taxa de polimorfismo $(\mathbf{P j})$}

Um gene é definido como polimórfico se a frequência de um de seus alelos é menor ou igual a 0,95 ou 0,99 . Este índice pode ser usado com marcadores codominantes e muito restritivamente com marcadores dominantes. Isto, pois há uma tendência de que as estimativas baseadas em marcadores dominantes sejam menores que o número real.

$$
P j=q \leq 0,95 \text { ou } P j=q \leq 0,99
$$

\section{ii) Proporção de lócus polimórficos}

É o número de lócus polimórficos dividido pelo total do número de lócus (polimórfico ou monomórfico). Este índice expressa o percentagem de lócus variáveis na população. Seu uso é mais apropriado para marcadores codominantes (explicação acima)

$$
\mathbf{P}=\mathbf{n}_{\mathrm{pj}} / \mathbf{n}_{\text {total }}
$$

\section{iii) Riqueza alélica (Ar)}

Refere-se ao número médio de variantes alélicas por loco por população. Para um dado loco em uma amostra, esta medida indica quantas variantes alélicas existem na população. Esta medida é geralmente mais sensível aos processos de deriva genética do que a heterozigosidade e permite se conhecer o número de alelos por loco independente do tamanho amostral. Este índice somente pode ser aplicado para marcadores codominantes, pois marcadores dominantes não permitem a detecção de alelos. 


\section{iv) Número médio de alelos por lócus}

É a soma de todos os alelos detectáveis em um loco dividido pelo número total de lócus. Este índice fornece uma informação complementar para o grau de polimorfismo. É também somente aplicado para marcadores codominantes.

$$
\mathrm{n}=(1 / K) \sum_{\mathrm{i}=1}^{\mathrm{K}} \mathrm{n}_{\mathrm{i}}
$$

Onde $\mathrm{k}=$ número de locus e ni = número de alelos detectado por lócus.

\section{v) Número efetivo de alelos (Ae)}

É o número de alelos que podem estar presentes em uma população. Este índice expressa o número de alelos que seria esperado em um loco em cada população. É calculado invertendo-se a medida de homozigosidade em um loco. É somente usado para marcadores codominantes o resultado pode ser afetado pelo tamanho amostral.

$$
\mathrm{Ae}=1 /(1-h)=1 / \Sigma \mathrm{p}_{\mathrm{i}}^{2}
$$

Onde: $\mathrm{pi}=$ frequência do $\mathrm{i}^{\text {th }}$ alelo em um lócus e $\mathrm{h}=1 / \Sigma \mathrm{p}_{\mathrm{i}}^{2}=$ heterozigosidade em um lócus.

\section{vi) Heterozigosidade esperada média (Diversidade gênica de Nei - D)}

É a probabilidade que em um loco, dois alelos quaisquer, escolhidos ao acaso em uma população, sejam diferentes um do outro. A média He em todos os lócus é uma estimativa da extensão da variabilidade genética em uma população. São possíveis três cálculos para He

Um loco com dois alelos: hj $=1-\mathrm{p} 2-\mathrm{q}^{2}$

Um loco j com i alelos: $\mathrm{hj}=1-\Sigma \mathrm{p}_{\mathrm{i}}^{2}$

Média sobre vários lócus: $\mathrm{H}=\sum_{\mathrm{j}}^{\mathrm{L}} \mathrm{hj} / \mathrm{L}$

\subsubsection{Quantificação da diversidade genética interpopulacional}

Os métodos para avaliar diferenças populacionais foram iniciados com os trabalhos de Sewall Green Wright, geneticista americano que estabeleceu os primeiros parâmetros matemáticos para quantificar o efeito do endocruzamento na estruturação populacional. Em seu trabalho de 1921, Wright usa pela primeira vez o termo Índice de Fixação (WRIGHT, 1921). 
Este índice foi e tem sido usado como indicador de diferenciação genética entre populações. Sendo que fixação o resultado do aumento da homozigosidade devido ao aumento de endogamia. A estruturação populacional é gerada pela perda de variação genética (medida pela heterozigosidade) nas populações devido aos efeitos da deriva genética. Assim, a estruturação de uma população é o resultado da diminuição da heterozigosidade nas subpopulações quando comparada a heterozigosidade esperada na população original. Para melhor entender este modelo, Wright propôs níveis hierárquico para os Índices de Fixação (F) (WRIGHT, 1951; 1965).

$\mathrm{F}_{I S}($ Individual within Subpopulation $)=$ Este é o Coeficiente de Endogamia $(f)$, que pode ser explicado pela probabilidade de que dois alelos em um indivíduo sejam idênticos por descendência (autozigotos). $\mathrm{O} \mathrm{F}_{I S}$ é um índice que correlaciona à junção de gametas relativa aos gametas tirados ao acaso dentro de um subpopulação. É matematicamente representado por $\mathrm{F}_{\mathrm{IS}}=H_{\mathrm{S}}-H_{\mathrm{I}} / H_{\mathrm{S}}$ ou 1- $\left(H_{\mathrm{I}} / H_{\mathrm{S}}\right)$, onde $H_{\mathrm{I}}$ (heterozigosidade observada média em um grupo de populações, diversidade intrapopulacional todas subpopulações) e $\mathrm{H}_{\mathrm{S}}$ (heterozigosidade esperada em todas subpopulações). Este índice gera um valor numérico que indica o quanto a heterozigosidade está abaixo do valor esperado dentro da população. $\mathrm{O} \mathrm{F}_{I S}$ varia de $-1 \mathrm{a}+1$, sendo que o valor negativo sugere um excesso de heterozigotos (exogamia) e o positivo indica um déficit de heterozigotos (endogamia) quando comparado com os valores esperado no equilíbrio de Hardy-Weinberg.

$\mathrm{F}_{S T}($ Subpopulation within the Total population $)=$ Este nível hierárquico de subdivisão populacional está relacionado a redução da heterozigosidade em um subpopulação em razão da deriva genética. Esta medida é a mais utilizada para avaliar a diferenciação total entre várias subpopulações. Este índice pode ser entendido pela correlação entre gametas dentro de populações que se unem para formar zigotos relativos aos gametas retirados ao acaso das subpopulações como um todo. $\mathrm{O} \mathrm{F}_{S T}$ mede o nível de diferenciação genética entre populações e é calculado pela seguinte equação; $\mathrm{F}_{S T}$ $=H_{\mathrm{T}}-H_{\mathrm{S}} / H_{\mathrm{T}}$ ou 1- $\left(H_{\mathrm{s}} / H_{\mathrm{T}}\right)$, onde $H_{\mathrm{T}}$ (heterozigosidade esperada da população total) e $\mathrm{H}_{\mathrm{S}}$ (heterozigosidade esperada média estimada de cada população). Outra maneira de se calcular o índice de fixação de Wright é pela expressão $\mathrm{F}_{S T}=\sigma_{p}^{2} /\left[\not^{-}(1-\not \bar{p})\right]$, onde $\sigma_{p}^{2}$ é a variância da frequências alélicas e p é média das frequências alélicas em todas as populações. A medida de divergência gerada pelo $\mathrm{F}_{S T}$ é sempre positiva e varia de 0 (ausência de diferenciação genética, as populações estão em panmixia) a um máximo de 1 (completo isolamento das populações, indicando a fixação de alelos alternativos nas populações). Por exemplo, se o $\mathrm{F}_{S T}=0,48$ for estimado entre duas populações, isto significa que há uma substancial diferenciação entre elas, 
isto é, $48 \%$ do total da variação genética estão distribuídas entre as populações e $52 \%$ da variação estão dentro das populações. Há uma relação entre o número de migrantes e o índice $\mathrm{F}_{S T}$. Por exemplo, uma população de peixes se divide em duas populações que divergem ao longo do tempo, porém, ainda compartilham alguns migrantes entre as populações com igual chance, então se verifica que $F_{\mathrm{ST}}$ e $\mathrm{Nm}$ possuem uma relação inversa $\left(F_{\mathrm{ST}}=1 / 4 \mathrm{Nm}+1\right)$, isto é quanto maior o número de migrantes menor o valor de $\mathrm{F}_{S T}$ e vice-versa.

Wright (1978) propôs um guia geral para interpretar os valores de $\mathrm{F}_{S T}$ baseados em dados de aloenzimas. De 0 a 0,05 pode ser considerado como pequena diferenciação populacional; 0,05 a 0,15 indica moderada diferenciação populacional; 0,15 a 0,25 indica grande diferenciação populacional e acima de 0,25 indica uma extensa diferenciação populacional.

$\mathrm{F}_{I T}=($ Individual within the $\boldsymbol{T}$ otal population $)=$ Este índice não geralmente usado nas análises e representa o nível de endogamia $(f)$ de um indivíduo relativo ao total da população. Pode ser representada matematicamente por $\left(1-\mathrm{F}_{I T}\right)=\left(1-\mathrm{F}_{I S}\right)\left(1-\mathrm{F}_{S T}\right)$.

Uma questão limitante do $\mathrm{F}_{S T}$ é que este índice foi proposto a partir de um par de alelos sem mutação. No caso de um lócus com vários alelos em um modelo de número finito de populações como se aplicaria o índice $\mathrm{F}_{S T}$ ? $\mathrm{Na}$ década de 1970, o geneticista japonês Masatoshi Nei propôs uma extensão do índice de diferenciação populacional de Wright para múltiplos alelos, o $G_{S T}$ (NEI, 1972; 1973; 1975). Como a diversidade gênica é relativamente simples de ser calculada mesmo para alelos múltiplos, o índice proposto por Nei $\left(G_{S T}\right)$ resolveu a limitação do $\mathrm{F}_{S T}$ para alelos múltiplos. Assim, o $G_{S T}$ pode ser definido como a razão a diversidade gênica interpopulacional $\left(\mathrm{D}_{S \mathrm{~T}}\right)$ pela diversidade gênica total $\left(H_{\mathrm{T}}\right)$, isto é, $\mathrm{G}_{\mathrm{ST}}=H_{T}-H_{S} / H_{\mathrm{T}}$, onde $H_{S}$ é a diversidade gênica intrapopulacional e $H_{T}$ é a diversidade gênica total.

Em nota ao editor da revista Genetics, Takahata e Nei (1984), propuseram que o $\mathrm{G}_{S T}$ pode ser considerado um extensão do $F_{S T}$ de Wright para alelos múltiplos, visto que o $G_{S T}$ é a média ponderada do $\mathrm{F}_{S T}$ sobre o conjunto de alelos de um loco. Contudo, os autores reconhecem que a fórmula para definir $G_{S \mathrm{~T}}$ é complicada e sua relação com o $\mathrm{F}_{S T}$ não é clara, e esclarecem que o $\mathrm{G}_{S T}$ é a razão da diversidade gênica interpopulacional esperada pela diversidade gênica total esperada, e por isso, o valor de $G_{S T}$ pode ser estimado usando-se as médias das diversidades gênicas para vários lócus (NEI, 1977). A interpretação para a estimativa gerada pelo $\mathrm{G}_{S T}\left(\mathrm{D}_{S T}\right)$ quanto ao grau de diferenciação populacional é a mesma proposta por Wright (1978), e explicada anteriormente. 
A estatística $F$ proposta por Wright para estimar diferenciação populacional apresenta problemas principalmente no que se refere às amostras pequenas. As estimativas de diferenciação populacional devem ser capazes de corrigir os problemas relacionados à sub-representação das populações e também ao pequeno número amostral de cada população, questões estas que permeia os estudos de genética populacional. Em relação a isto, Weir e Cocherman (1984), propuseram um estimador não enviesado $(\Theta)$ de $\mathrm{F}_{S T}$ que corrige o erro associado a subrepresentação amostral de um população. Este estimador pode ser representado por $\Theta=\mathrm{a} / \mathrm{a}+$ $\mathrm{b}+\mathrm{c}$, onde $\mathrm{a}=$ variância entre populações, $\mathrm{b}=$ variância entre indivíduos dentro de populações e $\mathrm{c}=$ variância entre gametas dentro de indivíduos.

Outros índices para medir a diferenciação populacional foram propostos ao longo dos anos, tais como $N_{\mathrm{ST}}$ (LYNCH; CREASE, 1990) utilizado para avaliar a subdivisão populacional em variações nucleotídicas quando do uso de regiões do DNA mitocondrial. O $\mathrm{R}_{S T}$ (SLATKIN 1995 a;b) que foi desenvolvido para ser usado para marcadores microssatélites, e que incorporou o modelo de evolução por mutação passo a passo (stepwise mutation-SMM). A expressão matemática para $\mathrm{R}_{S T}$ é definida como $\mathrm{R}_{S T}=\left(\mathrm{S}_{\mathrm{T}}-\mathrm{S}_{\mathrm{W}}\right) / \mathrm{S}_{\mathrm{T}}$, a qual o valor gerado é a fração da variância total dos tamanhos dos alelos entre as populações e $\mathrm{S}$ é a soma das médias dos quadrados da diferença dos tamanhos dos alelos.

Este modelo propõe que um STR muda pelo ganho ou perda de apenas uma repetição, isto significa que dois alelos que diferem por uma repetição são provavelmente mais correlacionados (apresentam um ancestral mais recente) do que alelos que diferem por mais repetições. Este modelo é utilizado pelo índice $\mathrm{R}_{S T}$, embora problemas relacionados à homoplasia neste modo de evolução possam ocorrer. Outros modelos de diferenciação genética que também incorporaram o SMM foram o D (SHRIVER et al., 1995) e delta um (GOLDSTEIN et al. 1995).

Excoffier et al. (1992) e Excoffier (2001), propuseram uma abordagem diferente para mensurar a diferenciação genética entre populações na qual os índices de fixação podem ser calculados nos diferentes níveis de hierarquização que uma população pode estar estruturada, por exemplo, diferenciação dentro de uma população entre grupos de subpopulações, dentro de grupos entre subpopulações e dentro de uma população entre subpopulações (HARTL; CLARK, 2010). O método desenvolvido por estes autores se baseou na estimativa de diferenciação populacional gerada pela quantidade de diferenças mutacionais entre diferentes regiões genômicas. Este método chamado de AMOVA (Analysis of Molecular Variance) estima a diferenciação populacional diretamente de um dado molecular, obtido por um marcador molecular qualquer - RFLP, AFLP, RAPD, STR, Sequências de DNA, entre outros - para testar hipóteses de estruturação populacional. 
A AMOVA utiliza um dado molecular como um vetor Booleano, indicando a presença ou ausência de um determinado marcador (uma base nucleotídica, um fragmento de restrição etc.). Os quadrados das distâncias Euclidianas são calculados entre todos os arranjos par a par dos vetores Boolean que por sua vez são arranjadas em matrizes e subdivididas em submatrizes que correspondem às subdivisões dentro de populações (EXCOFFIER et al., 1992). As somas destes quadrados são então analisadas dentro de uma estrutura de análise de variância convencional, isto possibilita testar hipóteses de subdivisão populacional em diferentes níveis hierárquicos (EXCOFFIER, 2001).

Para que os valores pudessem ser comparados com outros índices, tais como $F_{S T}$ ou $G_{S T}$, os componentes de variância os usados para gerar índices estatísticos chamados de Estatística-Phi (Ф) e são calculadas como demonstrado na tabela 4 abaixo:

Tabela 4. Níveis de hierarquização e a estatística- $\Phi$ derivada.

\begin{tabular}{lc}
\hline \multicolumn{1}{c}{ Nível de hierarquização populacional } & Estatística- $\Phi$ \\
\hline Entre subpopulações dentro de um grupo & $\Phi_{S G}=\sigma_{\mathrm{b}}{ }^{2} / \sigma_{\mathrm{b}}{ }^{2}+\sigma_{\mathrm{c}}{ }^{2}$ \\
Entre grupos dentro de uma população & $\Phi_{G T}=\sigma_{\mathrm{a}}{ }^{2} / \sigma^{2}$ \\
Entre subpopulação dente de uma população & $\Phi_{S T}=\sigma_{\mathrm{a}}{ }^{2}+\sigma_{\mathrm{b}}{ }^{2} / \sigma^{2}$ \\
\hline
\end{tabular}

A AMOVA leva em consideração algumas suposições são estabelecidas para este modelo de diferenciação populacional, tais como:

(i) Os indivíduos amostrados devem ser escolhidos independentemente e ao acaso;

(ii) Como as distribuições nulas (probabilidade de distribuição de um teste estatístico quando a hipostese nula é verdadeira) são obtidas por reamostragem, as distâncias Euclidianas têm que apresentar uma distribuição normal ou uma homogeneidade de variância;

(iii) Em razão do fenômeno da deriva genética, qualquer variante mutacional não pode ser considerado como uma representação total de todo o genoma, por isso, os dados gerados para análise deve ser derivado de um número adequado de marcadores genéticos.

(iv) As populações que estão sendo avaliadas devem apresentar cruzamentos inteiramente ao acaso de maneira que acasalamentos preferenciais ou endogamia não ocorra, pois ao contrário resultará em diminuição da heterozigosidade, e se a taxa de endogamia diferir entre populações, as estimativas dos índices de fixação tornam-se imprecisas. 
(v) Os efeitos da seleção não são inteiramente incorporados pela AMOVA. As intensidades de seleção podem diferenciar entre populações, e os seus efeitos sobre alelos ou conjuntos de alelos podem ser diferentes. As variâncias devido à deriva genética podem ser creditadas a erros de amostragem, contudo, a seleção sobre alelos diferentes é não aleatória, sendo assim qualquer diferença em frequência de um alelo qualquer não é representativo das variações alélicas como um todo.

Em 1997, Schneider e colaboradores do Laboratório de Genética e Biometria da Universidade de Genebra (Suiça) lançaram o Arlequin versão 1.1, um software para análise de dados genéticos populacionais (SCHNEIDER et al., 1997) O objetivo deste pacote computacional de análise genética foi o de utilizar a AMOVA dentro de uma interface amigável para o usuário que utiliza alguns dos diversos marcadores genéticos disponíveis para análise genética populacional. Desde a concepção do Arlequin várias atualizações já foram lançadas, versão 3.0 (EXCOFFIER et al., 2005) e atualmente a versão 3.5 (EXCOFFIER; LISCHER, 2010). Este pacote por sua facilidade de uso e por ser um pacote de acesso livre se popularizou nas últimas décadas nos estudos genético populacionais.

A natureza altamente polimórfica de alguns marcadores, como o STR, e seu uso cada vez maior como marcador codominante em estudos populacionais trouxe a tona, a partir do final da década de 1990, uma série de questões sobre os princípios das medidas de mensuração das diferenças genética populacionais. Como posto anteriormente, os diversos estimadores de distância genética, tais como $\mathrm{F}_{S T}$ e $\mathrm{G}_{S T}$ desenvolvidos desde a década 1930 tiveram como base de resultados trabalhos utilizando aloenzimas (LEWONTIN, 1991), sendo que a heterozigosidade foi utilizado como sinônimo de "diversidade", e como medida de diferenciação populacional.

Hedrick (1999), introduziu um importante debate sobre os cuidados que devem ser tomados em relação à utilização de estimadores como $\mathrm{F}_{S T}$ ou $\mathrm{G}_{S T}$ com marcadores altamente polimórficos, como os STRs. Este autor demonstrou que os níveis de diferenciação e distância genética entre populações são significativamente influenciados pelos altos níveis de heterozigosidade apresentados pelos STRs, e que, por isso, as informações geradas por marcadores altamente polimórficos devem ser tratadas de forma mais cuidadosa de que aqueles marcadores nucleares menos variáveis.

O uso da heterozigosidade nos índices $F_{S T}$ ou mesmo $G_{S T}$ como parâmetro na geração de valores quantitativos para se verificar o grau de diferenciação genética entre populações pode levar a resultados de difícil compreensão. Populações com altos níveis de heterozigosidade podem apresentar valores de diferenciação próxima à zero (panmixia ou baixo valor de diferenciação), mesmo que as populações em questão não compartilhem nenhum alelo. Da 
mesma forma, populações podem apresentar altos valores de diferenciação $(>0,25)$, mesmo compartilhando os mesmos alelos.

Jost (http://www.loujost.com/index.ht) contextualizou a influência da heterozigosidade nas estimativas de diferenciação populacional em programas de conservação genética. Quando a diversidade genética de uma espécie é conservada ou mesmo perdida com a manutenção ou perda de populações geneticamente distintas, devemos entender que a quantidade de diversidade perdida mais a quantidade de diversidade salva devem ser adicionadas ao total da diversidade, levando em consideração que outros fatores que afetem a diversidade sejam constantes.

Para entender esta ideia, vamos imaginar que as populações de uma espécie de peixe endêmica estejam ameaçadas. Suponhamos: (i) que estas populações estejam distribuídas em 20 tributários, (ii) que a espécie em questão seja muito sensível a alterações nos fluxos de água destes tributários, (iii) que a espécie mantenha suas populações restritas aos tributários efetuando migrações a montante para reproduzir e (iv) que possuam mais ou menos o mesmo tamanho populacional. Um estudo com marcadores com lócus STRs altamente polimórficos mostrou que cada uma das 10 populações apresenta uma heterozigosidade de 0,95, e que não há compartilhamento de alelos entre elas (todos os alelos são privativos).

Uma empresa hidroelétrica pretende usar nove destes tributários para construir barragens de pequeno porte para geração de eletricidade (PCHs). A alteração no fluxo de água dos tributários levará as populações provavelmente ao desaparecimento. A empresa está "preocupada" com a espécie e pergunta a um geneticista qual será o efeito que a construção das barragens ocasionará sobre a diversidade genética da espécie na bacia.

Ao seguir os procedimentos padrões para o cálculo dos índices de diversidade interpopulacional, a diversidade genética será equitativamente comparada a heterozigosidade total e o índice de diferenciação populacional obtido será baixo. O resultado poderá ser usado pela empresa que argumentará que não havendo diferenciação significativa entre as populações, ao salvar um dos tributários, estará preservando a quase totalidade da diversidade genética da espécie, pois se a heterozigosidade total das dez populações for de 0,9975 e a heterozigosidade da população não afetada pelo barramento for de 0,95 , a proporção de diversidade genética da espécie será de 95\% (=0,95/0,9975).

$\mathrm{Na}$ verdade, este resultado baseado na heterozigosidade como medida de diferenciação levará à extinção da quase totalidade da diversidade genética da espécie, pois se todas as populações são igualmente grandes e diversas e não há compartilhamento de alelos entre elas, cada população irá contribuir igualmente com o total da diversidade genética da espécie. A perda de nove das 10 populações, nas quais a espécie está distribuída causará o desaparecimento de 
$90 \%(=9 / 10)$ da diversidade genética da espécie, por outro lado ao se salvar uma população (tributário sem barragem) se preservará apenas 10\% $(=1 / 10)$ da diversidade genética da espécie.

Para contornar os problemas oriundos do uso da heterozigosidade nos cálculos de diferenciação populacional, Hedrick (2005), propôs um método para padronizar a medida interpopulacional, nomeado como $G_{S T}$ que é calculado dividindo-se o índice $G_{S T}$ gerado por um marcador pelo valor máximo observado de $G_{S T}$ dado o nível de heterozigosidade dentro das populações para o marcador escolhido. Este parâmetro é também interpretado da mesma maneira do $\mathrm{F}_{S T}$, de 0 (panmixia total) a 1 (estruturação total).

Jost (2008) introduziu outro índice de medida interpopulacional ( $\mathrm{D}$ ou $\mathrm{D}_{E S T}$ ) que mede a fração da variação alélica entre populações, isto é, o $D_{E S T}$ mede diretamente a diferenciação das frequências alélicas entre populações, não importando qual o tipo de modelo mutacional do marcador ou modelo de estruturação genética da espécie. $\mathrm{O}$ índice $\mathrm{D}_{E S T}$ de Jost gera um valor máximo de 1 se as populações são inteiramente diferenciadas (não compartilham nenhum alelo) e um valor mínimo de 0 se não há diferenciação (as populações compartilham todos os alelos com as mesmas frequências). O debate teórico sobre o uso dos índices de diferenciação genética tem sido intenso com mostra uma série de comentários na seção News and Views da revista Molecular Ecology que iniciou com comentários de Ryman e Leimar (2009) e Heller e Siegismund (2009) sobre o índice $\mathrm{D}_{E S T}$ de Jost e a consequente resposta de Jost (2009) na mesma seção. 


\section{Capítulo III - Recursos genéticos populacionais de peixes de água doce da região Neotropical}

\subsection{Sobre a região Neotropical}

A região Neotropical compreende a região do sul do México $\left(\sim 16^{\circ} \mathrm{N}\right)$ até o norte da Argentina $\left(\sim 34^{\circ} \mathrm{S}\right)$. A dinâmica de formação desta região remonta cerca de 90 milhões de anos, período pelo qual a América do Sul passou por importantes mudanças geológicas após seu isolamento da África e que moldou a formação de suas bacias hidrográficas (ALBERT; REIS, 2011). A evolução dos sistemas de drenagens na região Neotropical propiciou sua separação em diferentes bacias com característica geomorfológicas distintas que promoveu vicariância, divergência alopátrica e consequentemente aumento da diversidade da ictiofauna (LUNDBERG et al., 1998).

O número atual de espécies de peixes nominalmente registrado de acordo com o Fish Base (FROESE; PAULY, 2013) é de 32.500 espécies, sendo que 43\% deste total são peixes de água doce (NELSON, 2006). Reis et al. (2003) e Lévequé et al. (2008), destacam que 30\% do total das espécies de água doce formalmente descritas estão localizas na região Neotropical, ainda que se supõe que muita desta diversidade está para ser evidenciada aumentando o número de espécies de peixes nesta região.

Os ambientes de água doce, especificamente os localizados na região Neotropical, exibem uma grande variabilidade espacial e temporal (LOWE-MCCONNELL, 1987). Assim, da mesma forma que processos bióticos e abióticos podem ocasionar mudanças microevolutivas dentro de uma espécie, levando à especiação; em curto prazo processos dinâmicos de formação de barreiras geográficas, capturas de bacias, geodispersão, pulsos de inundação e outros processos vicariantes podem fazer com que espécies de peixes apresentem níveis diversos de diferenciação populacional (FELSENSTEIN, 1976; HENDRY et al., 2001; LENORMAND, 2002; ALBERT, 2010).

Sendo assim, a Região Neotropical abriga em seus ecossistemas aquáticos de águas continentais uma riqueza de recursos genéticos não somente no que concerne à quantidade de diferentes espécies, mas também em relação à variabilidade genética encontrada dentro e entre populações de peixes (BARLETTA et al., 2010). 


\subsection{Evolução dos estudos de genética populacional baseado em marcadores em peixes neotropicais}

Com o objetivo de avaliar a evolução do uso de marcadores genéticos para estudos populacionais de peixes Neotropicais de água doce, optou-se por revisar o conjunto de artigos publicados na área de acordo com seu aparecimento cronológico como descrito por Schlötterer (2004). Os artigos foram obtidos com o uso de dois bancos de dados: ISI Web of Science e ASFA (Aquatic Science and Fisheries Abstract). A localização dos artigos foi feita com a combinação das seguintes palavras chaves: freshwater fish, Neotropical, South America, Central America, genetic*, population, structur*, markers, isozyme, allozyme, RFLP, RAPD, microsatellite* STR, SSR, SNP, mitochondrial DNA. Apenas artigos com análises genéticas populacionais intraespecíficas com índices de fixação calculados, tais como $\mathrm{F}_{S T}, \mathrm{G}_{S T}, \mathrm{R}_{S T}, \Phi_{S T}, \mathrm{D}_{E S T}$ foram usados na revisão. Os índices médios de fixação para cada estudo foram obtidos, em caso de artigos em que apenas os índices de fixação par a par entre populações fossem fornecidos, a média dos valores foi calculado para obter o índice global.

\subsubsection{Marcadores Protéicos}

Apesar do uso de marcadores protéicos terem sido usados para estudos populacionais de peixes de água doce já na década de 1970 (KOEHN et al., 1971; ALLENDORF et al., 1977; BUTH; BURR, 1978), os primeiros estudos com peixes Neotropicais com estes maracadores foram publicados a partir da década de 1990.

A busca no banco de dados revelou 15 trabalhos publicados com o uso de marcadores protéicos em estudos genéticos com peixes Neotropicais entre 1990 e 2011. Dos 15 trabalhos, sete foram trabalhos com análises populacionais com espécies taxonomicamente determinadas, cujos trabalhos foram publicados em revistas indexadas com revisão por pares. Sete trabalhos utilizam marcadores protéicos, contudo com objetivos outros que não estritamente populacional. Estes trabalhos utilizam sistemas izoenzimáticos ou aloenzimáticos para medir níveis de variabilidade genética baseada em heterozigosidade esperada e identidade genética de Nei (NEI, 1972; 1978) para levantar hipóteses de especiação recente (statu nascendı) entre morfotipos populacionais de uma espécie de bagre da família Loricariidae - Rinelocaria pentamaculata e R. aff. Pentamaculata - (LIMEIRA et al., 2009) ou foram trabalhos de cunho sistemático em peixes da ordem Characiformes (CHIARI; SODRÉ, 1999), da ordem Siluriformes (RENESTO et al., 2000; ZAWADZKI et al., 2005; PAIVA et al., 2005; REUSING et al., 2011) e da ordem Gymnotiformes (REZENDE et al., 2009). 
O primeiro trabalho publicado com uma abordagem populacional avaliou amostras da espécie Leporinus friderici (Characiformes, Anostomidae) conhecido popularmente como piau ou piava três pintas (RENNO et al., 1990). Peixes do gênero Leporinus são de importância relativa para piscicultura brasileira (7.227,6 t; MPA, 2010) e para pesca continental (5.503,6; MPA, 2010). O trabalho objetivou verificar uma possível estrutura genética entre populações entre seis locais na Guiana Francesa e duas localidades no Brasil para investigar a hipótese de uma diferenciação genética recente devida refúgios formados na era Quaternária especificamente no escudo das Guianas. Neste trabalho os resultados foram: (i) 15 sistemas enzimáticos; (ii) 21 lócus avaliados; (iii) 8 localidades da Guiana Francesa e duas localidades no rio Solimões e no Rio Mogi Guaçu no Brasil; (iv) o número amostral por localidade não foi informado; (vi) Heterozigosidade média esperada total $=0,0816$; (vi) $D_{S T}\left(G_{S T}\right)=0,1196$. O resultado mostrou uma alta $(0,15-0,25)$ diferenciação genética das populações de L. friderici entre as duas regiões avaliadas.

Sete anos após publicação com L. friderici, Revaldaves et al. (1997), publicaram o primeiro estudo genético populacional com um espécie de grande importância para aquicultura $(5.226,0$ t; MPA, 2012) e para pesca (28.432,60 t; MPA, 2010), o Prochilodus lineatus - Characiformes Prochilodontidae, conhecido como curimbatá, curimatã ou curimbá. Este trabalho objetivou, com a utilização de parâmetros genéticos populacionais, avaliar possíveis diferenças genéticas entre populações locais da Bacia do Paraná e sua relação com as estratégias pesqueiras no manejo das populações da espécie e a preservação do meio ambiente na manutenção da variabilidade genética da espécie na região estudada. Os resultados mostraram uma baixa diferenciação genética $(p>0,05)$ das populações estudadas compreendendo como uma única unidade reprodutiva com alto fluxo gênico no trecho do rio Paraná estudado. O trabalho não faz nenhuma inferência sobre os hábitos migratórios da espécie em relação aos resultados encontrados. Neste trabalho os resultados foram: (i) 19 sistemas enzimáticos; (ii)12 lócus (6 polimórficos e usados na avaliação); (iii) 3 locais em um trecho a bacia do Rio Paraná; (iv) o número amostral total 160 espécimes; (v)Heterozigosidademédia esperada total $=0,132$; (vi) $\mathrm{F}_{S T}=0.018$.

Carvalho et al. (1991), publicaram um estudo com a espécie Poecilia reticulata conhecido como lebiste, espécie muito utilizada na aquarofilia. Esta espécie é amplamente distribuída em países da América do Sul e Central e foi introduzida da África para controle de mosquito (KOTTELAT; WHITTEN, 1996). Populações de lebistes de seis localidades da ilha de Trinidad e Tobago foram estudadas para estimar os níveis de divergência genética intra e interpopulacional. Neste trabalho os resultados foram: (i) 7 sistemas enzimáticos; (ii) 23 lócus; 
(iii) 6 locais; (iv) o número amostral total 270 espécimes, entre 23 e 53 para cada local de coleta; (v) Heterozigosidade média esperada total $=0,383$; (vi) $\mathrm{G}_{S T}=0.086$.

Em 1998, foi publicado por um grupo da Universidade Estadual e Ohio (EUA) o primeiro trabalho da região Neotropical na região norte do mar do Caribe (SCHUG et al., 1998). A motivação do grupo foi usar uma espécie modelo que habitasse cavernas isoladas com áreas de água doce (blueholes) na região da ilha de Andros nas Bahamas. A espécie escolhida foi Gambusia hubbsi - Cyprinodontiformes - Poeciliidae, conhecida como mosquitofish em Inglês e gambusia caribenho em Espanhol de ocorrência em Cuba, Jamaica, ilhas Cayman e Bahamas. O trabalho objetivou testar hipóteses de padrões de isolamento por distância em populações geograficamente isoladas por eventos geológicos e de colonização. Os autores propõem que cada caverna de água doce funciona como um reservatório populacional cujo fluxo gênico entre cavernas é praticamente inexistente. A deriva genética é a força determinante que leva a estruturação das populações de G. hubbsi na área estudada. O artigo sugere que o ambiente diferenciado entre as populações locais pode agir seletivamente sobre os fenótipos produzindo especialistas. Esta ideia corrobora o uso das metodologias de estudos populacionais para entender a existência de recursos genéticos intraespecíficos que devem ser mantidos para a conservação em longo prazo da espécie e/ou seu uso caso a espécie seja de utilização pelo homem. Neste trabalho os resultados foram: (i) 19 sistemas enzimáticos; (ii) 32 lócus (21 polimórficos em um ou mais lócus); (iii)14 cavernas de água doce (blueholes) e dois de águas superficiais ao norte da ilha de Andros;(iv) o número total amostral não informado; (v) Heterozigosidademédia esperada total $=0,0213 ;$ (vi) $F_{\mathrm{ST}}=0,38$.

O primeiro estudo genético populacional com o uso de isoenzimas em um peixe amazônico de grande importância econômica foi realizado em 1998 como dissertação de mestrado no programa de programa de pós-graduação em biologia tropical e recursos naturais do INPA juntamente com a Universidade do Amazonas (LEITÃO, 1998), e publicado em 2012 (Santos et al. 2012). O tambaqui é atualmente a principal espécie de peixe nativa em uso na piscicultura brasileira $(54.313,10$ t; MPA, 2010). Dentro do programa AquaBrasil de melhoramento genético coordenado pela EMBRAPA, o tambaqui foi uma das duas espécies de peixes nativos escolhidas para o programa (AQUABRASIL, 2009). O estudo genético objetivou comparar os parâmetros genéticos da população selvagem com exemplares de tambaqui usados em pisciculturas com diferentes tempos de confinamento. O estudo mostrou os efeitos do manejo genético não adequado de populações em cativeiro desde o estabelecimento das populações fundadoras até a perda de variabilidade genética de tais populações. Neste trabalho os resultados foram: (i) 9 sistemas enzimáticos; (ii) 18 lócus (6 polimórficos); (iii) 4 localidades - 
três estações de piscicultura: Estação de Piscicultura do DNOCS - Departamento Nacional de Obras contra a Seca - localizada em Pentecoste no Ceará (população Fortaleza), Centro de Aquicultura da UNESP em Jaboticabal - São Paulo, com animais provenientes da Estação de Piscicultura do mesmo DNOCS (população Jaboticabal) e Fazenda de Piscicultura "Amazonfish", localizada no município de Itacoatiara (AM), com alevinos provenientes da Estação de Piscicultura da Usina Hidrelétrica de Balbina (população Itacoatiara) e uma população selvagem coletada próximo a Manaus.; (iv) o número total amostral 149; (v) Heterozigosidade média esperada da população selvagem $=0,120$, populações de cativeiro: Fortaleza $=0,106$, Jaboticabal $=0,118$, Itacoatiara $=0,131 ;\left(\right.$ vi) $\mathrm{D}_{S T}\left(\mathrm{G}_{S T}\right)=0,019$ (entre as quatro populações).

O gênero Hoplias compreende um grupo de peixes da ordem dos Characiformes da família Erythrinidae na qual são descritas nove espécies (OYAKAWA, 2003). Hoplias malabaricus é uma destas espécies de ampla distribuição na região Netropical da Argentina (sul de Buenos Aires) até o Panamá (BERRA, 1981), tendo sua presença já sido detectada como espécie invasora no estado da Flórida nos EUA (HENSLEY; MOODY, 1975). O status taxonômico da espécie H. malabariucs é ainda um tema de controvérsia, pois alguns estudos apontam que há um complexo de espécies dentro do que vem sendo chamado de H. malabaricus. Estas evidências demonstram que além da variação morfológica, existe uma diversidade cariotípica, com diferentes citótipos variando de $2 \mathrm{n}=39$ a 2n=42 (BERTOLLO et al., 2000). Nos registros do Ministério da Pesca e Aquicultura (MPA, 2010), a produção pesqueira coloca todo o conjunto de espécies do gênero Hoplias como traíra com uma captura de $9.821,3$ t e a produção advinda da piscicultura de 266,3 t. Peres et al. (2002) estudou a variabilidade genética de duas populações de H. malabaricus residentes em ambiente lêntico e outra de um ambiente lótico localizados na bacia do Alto Paraná. Neste trabalho os resultados foram: (i) 14 sistemas enzimáticos; (ii) 23 lócus avaliados; (iii) 2 localidades; calha do Rio Paraná e lagoa temporária em uma das ilhas do mesmo rio; (iv) o número amostral total de 52;24 no rio e 28 na lagoa; (v) Heterozigosidade média esperada das duas população 0,049 ; (vi) $\mathrm{D}_{S T}\left(\mathrm{G}_{S T}\right)=0,012$.

O gênero Hypostomus compreende um grupo de bagres da família Loricariidae conhecidos por cascudos por possuírem uma armadura (placas ósseas) com 133 espécies validas (FROESE; PAULY, 2013). Habitam rios das Américas do Sul e Central. No Brasil, várias espécies deste gênero ocorrem em rios das bacias do Paraná e Paraguai (CARDOSO et al., 2012). Apesar de seu aspecto não comestível, representantes deste gênero estão relacionadas na lista dos peixes capturados pela atividade pesqueira (589,0 t; MPA, 2010), e também está na lista de espécies produzidas pela piscicultura nacional (37,1 t; MPA, 2010). Dois trabalhos populacionais foram publicados com espécies deste gênero. O primeiro (ZAWADZKI et al., 2002) avaliou duas 
populações alopátridas da espécie Hypostomus margaritifer coletadas em dois reservatórios para geração de energia elétrica. Análises morfológicas em conjunto com eletroforese de proteínas foram realizadas para investigar se há diferenças entre as populações. Os resultados mostram que as duas populações não apresentaram diferenças morfológicas, a não ser por padrões de coloração. A avaliação genética populacional com proteínas não mostrou diferença genética entre as populações presentes nos dois reservatórios. Os autores deste trabalho concentraram-se mais na questão sistemática, confirmando que as duas populações pertencem à mesma espécie, do que abordagens genéticas populacionais. Neste trabalho os resultados foram: (i) 14 sistemas enzimáticos; (ii) 25 lócus avaliados; (iii) 2 localidades na bacia do rio Paraná; a primeira no reservatório de Itaipu e o segundo no reservatório de Corumbá; (iv) o número amostral total de 30 - 15 por localidade; (v) Heterozigosidade média esperada dasduas população 0,0825 ; (vi) $D_{\text {ST }}$ $\left(\mathrm{G}_{S T}\right)=0,012$.

O segundo trabalho foi realizado com a espécie Hypostomus regain nos mesmos dois reservatórios do trabalho anterior com mais um população do reservatório do Manso na bacia do rio Paraguai (ZAWADZKI et al., 2008). Ao contrário dos resultados do trabalho com a espécie Hypostomus margaritifer, neste trabalho foi encontrado uma alta diferenciação populacional entre as três populações. No trabalho não há uma possível explicação dos resultados diferentes de diferenciação populacional das duas espécies coletadas nos mesmos dois reservatórios. Neste trabalho os resultados foram: (i) 14 sistemas enzimáticos; (ii) 25 lócus avaliados; (iii) 3 localidades na bacia do rio Paraná; a primeira no reservatório de Itaipu e o segundo no reservatório de Corumbá e uma no resertório do Manso na bacia do rio Paraguai; (iv) o número amostral total de 90 - 25 do reservatório de Corumbá, 32 Itaipu e 33 do Manso; (v) Heterozigosidade média esperada das duas população 0,0542; (vi) $\mathrm{F}_{S T}=0,1728$.

Coronel et al. (2004), estudaram populações de duas espécies de bagres de grande importância para pesca na Amazônia boliviana; Brachyplatystoma flavicans, conhecida como dourada e Pseudoplatystoma fasciatum, conhecida como cachara no Brasil. A pesca da dourada foi estimada em 14.379,4 t e da cachara 1.038,1 t em 2010 (MPA, 2010). Amostras de tecidos foram coletadas em populações de duas localidades nos Rios Ichilo e Beni e também em área alagadas na região em território boliviano. O presente trabalho utilizou dois marcadores aloenzimas e RFLP mitocondrial. No caso da dourada, não foi apresentado resultados de diferenciação populacional para alozimas, somente para RFLP mitocondrial, já para a cachara, os autores sugerem que as três populações desta espécie representa uma única unidade reprodutiva, com um $\mathrm{F}_{S T}$ entre 0 e 0,05. Para a espécie Brachyplatystoma flavicans os resultados foram: (i) 9 sistemas enzimáticos; (ii) 18 lócus avaliados; (iii) 2 localidades nos rios Ichilo e Beni; (iv) o número amostral total de 49 (46 
do rio Ichilo e 3 do rio Beni); (v) Heterozigosidade média esperada das duas população 0,012; (vi)índice de diferenciação populacional não calculado. Para a espécie P. fasciatum os resultados foram: (i) 9 sistemas enzimáticos; (ii) 18 lócus avaliados; (iii) 3 localidades nos rios Ichilo, lagos do Ichilo e Beni;(iv) o número amostral total de 69 (37 do rio Ichilo, 17 dos lagos e 15 do rio Beni); (v) Heterozigosidade média esperada das duas população 0,017 ; (vi) $\mathrm{F}_{S T}=0,010$.

Outro trabalho realizado com uma espécie da ordem dos Siluriformes comparou duas populações da espécie Rineloricaria pentamaculata coletadas em dois tributários do Rio Ivaí na bacia do Alto Paraná (LIMEIRA et al., 2009). Os resultados sugerem que os dois morfotipos são populações diferentes da mesma espécie. Neste trabalho foram usados: (i) 12 sistemas enzimáticos; (ii) 22 lócus avaliados; (iii) 2 tributários do rio Ivaí na bacia do Alto Paraná; (iv) o número amostral total de 35, sendo 13 em uma localidade e 22 na outra; (v) Heterozigosidade média esperada das duas população=0,0806; (vi) $\mathrm{F}_{S T}=0,1309$.

O último trabalho publicado sobre avaliação genética populacional com o uso de marcadores protéicos até a presente revisão utilizou aloenzimas para estudar populações da espécie Astyanax altiparanae. O gênero Astyanax é o mais diversificado da família Characidae na região Neotropical cuja ocorrência é ampla nas diversas bacias hidrográficas brasileiras (GÉRY, 1977). Peres et al. (2005), estudaram populações de duas regiões da bacia do alto Paraná. Neste trabalho os resultados foram: (i) 13 sistemas enzimáticos; (ii) 21 lócus avaliados; (iii) 2 localidades na bacia do Alto Paraná; (iv) o número amostral total de 64, sendo 31 em uma localidade e 33 na outra; (v) Heterozigosidade média esperada das duas população=0,1225; (vi) $\mathrm{F}_{S T}=0.1455$.

\subsubsection{Discussão sobre marcadores protéicos}

Em 1974, um importante livro sobre aspectos teóricos da genética de populações de peixes (ALTUKVOV, 1974) e posteriormente um capítulo no volume III da coleção Fish Physiology (ALLENDORF; UTTER, 1979) apresentaram a importância da eletroforese de proteínas como uma metodologia viável para estudos de diferenciação genética entre populações de peixes.

No Brasil, os estudos pioneiros sobre genética de peixes tiveram como foco análises citogenéticas, inclusive para abordagens populacionais (TOLEDO et al., 1978; FORESTI, 2008). Alguns dos trabalhos na década de 1970, com o uso de marcadores protéicos, concentravam-se mais na elucidação da evolução da estrutura, função e regulação gênica de sistemas isoenzimáticos da desidrogenase láctica em algumas espécies de peixes neotropicais (TOLEDO 
et al., 1977). Contudo, poucos foram os trabalhos sobre estudos genéticos populacionais em espécies de peixes de água doce de ecossistemas neotropicais com uso de eletroforese de proteínas.

Dez foram os trabalhos revisados que de alguma forma avaliaram populações de peixes neotropicais com o uso de índices de diferenciação genética gerados por isoenzimas ou aloenzimas. Estes trabalhos foram publicados entre 1990 e 2008, sendo cinco deles na década de 1990 e cinco entre 2003 e 2012. Infelizmente, os estudos sobre genética populacional de peixes neotropicais com o uso de marcadores protéicos durante o período mais intenso do uso desta metodologia é praticamente insignificante frente à representativa ictiodiversidade na região neotropical. Dos nove estudos, cincos foram com espécies da ordem Characiformes, três da ordem Siluriformes e dois da ordem Cyprinodontiformes. A tabela a seguir mostra o resumo de alguns importantes parâmetros para se entender os resultados obtidos:

Tabela 5. Valores médios dos parâmetros genéticos avaliados por proteínas em estudos populacionais de pexies neotropicais.

\begin{tabular}{lccc}
\hline & Characiformes & Siluriformes & Cyprinodontiformes \\
\hline Número de espécies avaliadas & 5 & 5 & 2 \\
Sistemas protéicos & 14 & 12 & 13 \\
Número de lócus & 21 & 22 & 25 \\
Número de espécimes avaliados & 109 & 57 & $49 *$ \\
$\mathbf{G}_{\mathrm{ST}}$ ou $\mathbf{F}_{\mathrm{ST}}$ total & 0,0658 & $0,0814^{* *}$ & 0,2054 \\
$\mathbf{H e}$ & $26,24 \%$ & $3,51 \%$ & $3,61 \%$ \\
\hline
\end{tabular}

*Este número corresponde ao trabalho com a espécie Poecilia reticulata; no trabalho com a espécie Gambusia bubbsi o número amostral por localidade não foi apresentado.

**Este valor corresponde à média de quatro espécies.

Gyllensten (1985), publicou um primeiro levantamento de resultados genéticos populacionais baseados em estudos genéticos populacionais com o uso de marcadores protéicos, comparando espécies de peixes marinhos, espécies anádromas e estritamente de água doce. Nesta revisão o referido autor utilizou nove espécies de água doce provenientes do hemisfério norte. $\mathrm{O}$ valor de heterozigosidade médio foi de 4,3\% e do índice de fixação $G_{S T}$ foi de 0,328. Em 1994, Ward et al. (1994) expandiu este estudo para um número maior de espécies, no caso de água doce para 49 espécies. Neste estudo o valor de heterozigosidade total média foi de 6,2\% e do índice de fixação $G_{S T}$ foi de 0,222 .

Os valores médios de diferenciação populacionais $\left(\mathrm{G}_{S T}\right.$ ou $\left.\mathrm{F}_{S T}\right)$ gerados pelos trabalhos com espécies de peixes neotropicais de água doce (0,0658 para Characiformes, 0,0814 para 
Siluriformes e 0,2054 para Cyprinodontiformes) mostram padrões de diferenciação populacional, que estão abaixo da média encontrada para peixes do hemisfério norte (Tab. 6). A heterozigosidade média das espécies neotropicais foi de 5,56\% e ficou entre as médias quando de heterozigosidade média das espécies temperadas dos dois trabalhos citados (4,3\% e 6,2\%, respectivamente).

Tabela 6. Resumo comparativo dos índices médios de variabilidade genética e de diferenciação populacional entre os estudos citados.

\begin{tabular}{lccc}
\hline & $\begin{array}{c}\text { Espécies Neotropicais } \\
\text { (presente } \\
\text { levantamento) }\end{array}$ & $\begin{array}{c}\text { Revisão } \\
\text { (Gyllensten, 1985) }\end{array}$ & $\begin{array}{c}\text { Revisão } \\
\text { (Ward et al., 1994) }\end{array}$ \\
\hline Heterozigosidade & $5,56 \%$ & $4,3 \%$ & $6,2 \%$ \\
$\mathbf{G}_{\boldsymbol{S T}}$ ou $\mathbf{F}_{\boldsymbol{S}}$ & 0,1175 & 0,3280 & 0,2220 \\
\hline
\end{tabular}

Os resultados comparativos apresentados acima de diferenciação populacional e heterozigosidade com o uso de marcadores protéicos não podem ser considerados representativos para as espécies neotropicais, pois o número de estudos com esta metodologia é muito pequeno.

A pouca produção de trabalhos com marcadores protéicos com peixes de água doce neotropical no período mais intenso desta metodologia, nas décadas de 1970 e meados da década de 1980 talvez possa ser explicada pelas dificuldades inerentes a tais estudos. A manutenção dos vários tecidos para ampliar o máximo de lócus a serem estudados depende do transporte de tambores de nitrogênio líquido para preservar a estrutura das proteínas a serem usados na eletroforese. Isto na maioria das vezes dificulta amplas amostragens nas áreas de ocorrência das espécies. Isto é corroborado pelo padrão de coleta dos trabalhos, que na maioria das vezes foram realizadas em áreas restritas com espécies de relativa facilidade de coleta. Naturalmente, com o desenvolvimento de outros marcadores baseados diretamente no polimorfismo do DNA, a eletroforese de proteínas foi sendo abandonada e atualmente poucos são os grupos de pesquisa no Brasil e em outros países da região neotropical que a utiliza. 


\subsubsection{Marcadores baseados no DNA mitocondrial}

\subsubsection{RFLP (Restriction Fragment Length Polymorphism)}

Na década de 1970 iniciou-se uma transição em direção ao uso de outros marcadores baseados diretamente no DNA. Incertezas surgiram sobre os resultados gerados pelo polimorfismo visualizados na eletroforese de proteínas em razão de uma possível não neutralidade evolutiva destes marcadores (KIMURA, 1968; NEI, 1975; FERGUSON, 1980). Este foi e ainda tem sido um tema de controvérsia em relação ao uso de marcadores genéticos para estudos populacionais (LEWONTIN, 1974). De qualquer maneira, o uso dos marcadores protéicos teve sua importância para estudos genéticos populacionais principalmente no que se refere a sua aplicação para o manejo de população de peixes de interesse econômico, pois as características biológicas de certas espécies de peixes, como os salmões, estariam propensas a se subdividirem em unidades reprodutivas menores, aumentando, assim, os efeitos de deriva genética sobre tais populações (ALLENDORF; UTTER, 1979).

Na década de 1980, a molécula do DNA mitocondrial (DNAmt) despertou a atenção dos geneticistas de populações, pois esta molécula apresenta características favoráveis para estudos genéticos populacionais. De maneira geral, algumas destas características são: (i) é uma molécula dupla hélice circular (BROWN; VINOGRAD, 1974); (ii) possui pequeno tamanho quando comparada ao DNA nuclear (BROWN, 1985); (iii) possui herança materna (Giles et al., 1980); (iv) apresenta processos de replicação e transcrição independente do DNA nuclear (Birky, 1978); ocorre em abundância nas células (BOGENHAGEN; CLAYTON, 1974), (v) não apresenta processos de recombinação gênica (HAYASHI et al., 1985), (vi) os indivíduos são geralmente homoplásmicos para um haplótipo (BROWN, 1985); é um marcador neutro (BROWN et al., 1982; BALLARD; KREITMAN, 1995) e (vii) possui uma taxa de evolução de 5 a 10 vezes maior que o genoma nuclear (BROWN et al., 1982).

O desenvolvimento tanto de técnicas de isolamento de DNA mitocondrial (WHITE; DENSMORE, 1992; CHAPMAN; POWERS, 1984) como de técnicas de hibridização de DNA - Southern blot - (SOUTHERN, 1975), com a clonagem do DNA mitocondrial para ser usado como sonda para hibridização intra e interespecífica (MANGINI et al., 1985; GONZÁLEZVILLASENÕR et al., 1986) em peixes possibilitou a realização de uma série de estuos genéticos populacionais com o uso da técnica do RFLP (LANSMAN et al., 1981; NEI; TAJIMA, 1981; FERRIS; BERG, 1987; HALLERMAN; BECKMANN, 1988; BILLINGTON; HEBERT, 1991).

Com o advento da técnica de PCR e o desenvolvimento de iniciadores específicos para DNAmt (KOCHER et al., 1989), surge uma nova perspectiva de aplicação da técnica do RFLP 
em regiões específicas do DNAmt (BECKENBACH, 1991). O RFLP foi usado com relativa frequência na década 1990, pois custos elevados e processos laboriosos não possibilitavam o uso do sequenciamento de regiões específicas do DNAmt para estudos genéticos populacionais. Com o surgimento de equipamentos mais modernos e rápidos de sequenciamento (METZKER, 2005), os estudos genéticos populacionais migraram para a comparação direta de sequências, o que possibilitou evidenciar polimorfismos fora de sítios de restrição, os quais não eram observados pela técnica do RFLP.

Renno et al. (1991), usaram a técnica do RFLP para estudar a estrutura genética da espécie Leporinus friderici isoladas em diferentes bacias localizadas na Guinada Francesa para verificar a formação de refúgios como explicação para diferenciação populacional e especiação alopátrica. Este trabalho sugeriu uma significativa estrutura biogeográfica das populações estudadas. Contudo, a hipótese proposta não foi baseada em cálculos de índices de diferenciação genética e sim pela presença ou ausência de haplótipos que os autores chamam de multiformas (multimorphs). Neste trabalho os autores utilizam um RFLP do DNAmt integral da espécie, porém, sem a utilização de sondas marcadas por transferência via Southern blotting. Apesar de não deixar isto claro, os autores utilizaram técnicas de isolamento de DNAmt (as citações destas técnicas estão em referências de uma tese e um artigo, ambos em publicados em Francês). Abordagem semelhante do uso do polimorfismo do DNAmt para identificação de haplótipos sem o uso de hibridização com sondas por isolamento de DNAmt foi utilizado em trabalho com Rattus norvegicus (HILSDORF; KRIEGER, 1999), no qual utilizou a metodologia de isolamento de DNAmt por gradiente de sacarose descrita por Chapman e Powers (1984). Os seguintes resultados obtidos foram: (i) 7 enzimas de restrição de seis pares de bases foram usadas; (ii) 30 espécimes no total foram avaliados para cinco populações; (iii) diversidade haplotípica $(b)$ total não informada; (iv) divergência nucleotídica $(\pi)$ total não informada; (v) índice de divergência populacional não informado.

Dois trabalhos realizados na década de 1990 aplicaram o RFLP em todo DNAmt para estudar duas espécies de peixes neotropicais. A primeira (não publicada) foi realizada em tese de doutoramento (CALCAGNOTTO, 1998) com espécies de peixes redondos (Piaractus mesopotamicus - pacu, Piaractus brachipomus - pirapitinga, Colossoma macropomum - tambaqui e Mylossoma duriventre - pacupeva) e híbridos (tambacu). Este estudo avaliou bancos genéticos de reprodutores destas espécies mantidos por estações de piscicultura. Neste trabalho, a técnica de Southern blotting foi usada com sondas não clonadas da espécie Piaractus mesopotamicus. O trabalho comparou a divergência nucleotídica entre as espécies citadas e forneceu dados de divergência haplotípica apenas dos estoques de pacu e tambaqui, 19,06\% e 23,765, respectivamente. Os 
dados gerados de variabilidade do DNAmt foi discutido no contexto do manejo dos bancos genéticos das espécies mantidas em cativeiro por órgãos governamentais para programas de repovoamento.

Em outro trabalho de doutoramento (HILSDORF, 1999), publicado em 2002 (HILSDORF et al., 2002) utilizou a técnica de Southern blotting em todo DNAmt para estudar a variabilidade genética da espécie Brycon opalinus nativa da bacia do Paraíba do Sul. Esta espécie é uma das espécies usadas nos programas de repovoamento realizados pela Estação de Hidrobiologia e Aquicultura de da CESP de Paraibuna (SP). Este trabalho foi o primeiro estudo publicado até então para testar a utilidade de do DNAmt para se avaliar populações selvagens e de cativeiro de uma espécie de peixe neotropical em programas de repovoamento. Neste trabalho, o DNAmt da espécie B. opalinus foi clonado e usado posteriormente para hibridização com sondas radioativas $\left(\mathrm{P}^{32}\right)$. Durante o desenvolvimento deste estudo, as sondas foram desenvolvidas a partir do isolamento de DNAmt de ovas de fêmeas. Contudo, a opção pelo não sacrifício de espécimes selvagens e dos reprodutores usados para os programas de repovoamento, levou a desenvolvimento de uma técnica de biopsia de tecido muscular (rico em mitocôndrias) para isolamento do DNA total e hibridização por sondas homólogas da espécie (HILSDORF et al., 1999). Altos índices de estruturação genética nas populações selvagens e de variabilidade intrapopulacional em ambas as populações selvagens e de cativeiro foram encontrados. Aspectos sobre as implicações destes achados em programas de repovoamento foram também discutidos neste trabalho. Os seguintes resultados foram obtidos: (i)24 enzimas de restrição foram usadas; (ii) 256 espécimes no total foram avaliados para 7 populações selvagens e 1 de cativeiro; (iii) diversidade haplotípica total $(h)=60 \%$; (iv) divergência nucleotídica média $(\pi)=0.825 \%$; (v) índice de divergência populacional pela $\operatorname{AMOVA}\left(\Phi_{C T}\right)=0,281$.

O último trabalho que se tem registrado com o uso de Southern blotting com DNAmt foi publicado por Moysés e Almeida-Toledo (2002). Este estudo avaliou cinco espécies do gênero Astyanax, tendo comparado as divergências nucleotídica interespecífica e diversidade haplotípica entre espécies e populações de duas espécies $A$. altiparanae e $A$. fasciatus. Os seguintes resultados foram obtidos: (i) 24 enzimas de restrição foram usadas; (ii) 94 espécimes no total, sendo 30 para 3 populações de $A$. altiparanae, 28 para 3 populações de $A$. fasciatus, 6 para 1 população de $A$. lacustres, 12 para 1 população de $A$. scabripinnis paranae e 18 para 1 população de $A$. schubarti; (iii) diversidade haplotípica total $(b)=53,3 \%$ (A. altiparanae), 80\% (A. fasciatus), 73,3\% (A. lacustres), 16,6\% (A. scabripinnis paranae ) e 64\% (A. schubarti); (iv) divergência nucleotídica $(\pi)=0,1567 \%$ (A. altiparanae), 0,2867\% (A. fasciatus), 0,18\% (A. lacustres), 0,11\% (A. scabripinnis paranae ) e 0,24\% (A. schubarti); (v) índice de divergência populacional não informado. 
A partir dos anos 2000, o uso da metodologia de amplificação do DNA pela PCR tornouse mais extenso com o sequenciamento e a disponibilização de sequências em bancos públicos de dados (GenBank). A técnica da RFLP migrou da utilização de sondas marcadas para amplificação de regiões específicas do DNAmt seguido do uso de enzimas de restrição, técnica conhecida como PCR-RFLP. Em um primeiro trabalho com lebistes (Poecilia reticulate) de Trinidad Tobago; Becker e Magurran, (2000), usaram o gene NADH2 que foi testado com apenas duas enzimas para verificar o fluxo gênico materno entre populações separadas por uma barreira natural. Neste trabalho os autores não apresentaram índices de diferenciação populacional e variabilidade genética.

Outro trabalho que utilizou a abordagem da PCR-RFLP avaliou junto com alozimas (comentado no item sob

re proteínas) a variabilidade genética de duas espécies de bagre da região amazônica Brachyplatystoma flavicans e P. fasciatum (CORONEL et al., 2004). Os seguintes resultados foram obtidos: (i) Região do DNAmt usada: ND5/6, Cyt b e D-loop; (ii) Tamanho do amplicons=2,4 kb (ND 5/6) e 2,25 kb (Cyt b e D-loop); (iii) 7 enzimas de restrição foram usadas; (iv) 2 populações para B. flavicanse 3 paraP. fasciatum; (v) espécimes avaliadas: 49 (B. flavicans)e 69 (P. fasciatum); (vi) diversidade haplotípica total $(h)=60,9 \%$ (B. flavicans) e 24,5\% (P. fasciatum);(vii) divergência nucleotídica $(\pi)=6,35 \%$ (B. flavicans) e 0,9\% (P. fasciatum); (viii) índice de divergência populacional $\Phi_{S T}=0,146$ para a espécie $P$. fasciatum.

Duas populações da Astyanax fasciatus (lambari do rabo vermelho) foram coletadas na bacia do rio Tibagi no Parque Estadual de Vila Velha (MATOSO et al., 2010) e trecho da região do Dloop mitocondrial $(1,3 \mathrm{~kb})$ foi amplificado. O trabalho propõe uma distinção genética entre as duas populações, contudo não apresenta índices de diferenciação genética que corroborem tal proposição.

O curimbatá (Procbilodus lineatus) mais uma vez foi alvo de um estudo genético populacional na região da bacia do alto Paraná (GARCEZ et al., 2011). Desta vez, a região do Dloop mitocondrial $(1,37 \mathrm{~kb})$ foi amplificada e os respectivos amplicons foram avaliados pela PCRRFLP. Os resultados corroboraram outros trabalhos que mostraram a ausência de diferenciação genética entre populações desta espécie. No presente trabalho, a hipótese de isolamento por distância foi rejeitada. Os seguintes resultados foram obtidos: (i) Região do DNAmt usada: Dloop; (ii) Tamanho do amplicons=1,37 kb; (iii) 15 enzimas de restrição foram usadas; (iv) 8 populações; (v) 149 espécimes avaliadas; (vi) diversidade haplotípica total (b) = 77,21\%; (vii) 
divergência nucleotídica $(\pi)=1,6 \%$; (viii) índice de divergência populacional entre populações nos rios Grande, Pardo e Mogi-guaçu $\Phi_{C T}=-0,0075$ e entre populações dentro dos rios $\Phi_{S C}=$ 0,0324 .

\subsubsection{Avaliação populacional por comparação de sequências do DNAmt}

Avaliações genéticas populacionais baseadas em comparações de sequências começaram a ser mais intensamente utilizadas quando se observa o crescimento de estudos publicados com esta abordagem com peixes de água doce neotropicais. O levantamento bibliográfico realizado constatou um total de 21 artigos que avaliaram a diferenciação genética populacional de peixes neotropicais. No presente levantamento, foi constatado que alguns trabalhos importantes nas áreas filogeografia e filogenia foram publicados com diferentes ordens de peixes de água doces neotropicais (BERMINGHAM; MARTIN, 1998; LOVEJOY; ARAÚJO, 2000; SIVASUNDAR et al., 2001; DERGAM et al., 2002; MONTOYA-BURGOS, 2003; TURNER et al., 2004; MOYER et al., 2005; RENNO et al., 2006; HAUSDORF et al., 2011). Os artigos apresentados a seguir utilizaram a comparação de sequências de diferentes regiões do DNAmt para análises de diferenciação genético populacional. Com o objetivo de uma melhor divisão, os artigos foram separados e agrupados por divisão taxonômica em nível de ordem. O primeiro conjunto de estudos apresnetados foi os realizados com espécies da ordem dos Characiformes.

Martins et al. (2003), estudaram a piapara Leporinus elongatus na bacia do alto Paraná. Os seguintes resultados foram obtidos: (i) Região do DNAmt usada: D-loop; (ii) Tamanho do amplicons= 1,3 kb; (iii) 6 populações; (iv) 43 espécimes avaliadas; (iii) diversidade haplotípica total $(b)=95,80 \%$; (iv) divergência nucleotídica $(\pi)=3,51 \%$; (iv) índice de divergência populacional entre populações não calculado.

Machado et al. (2005), avaliaram populações de dourado (Salminus brasiliensis) em rios das regiões de Corrientes (Argentina), Uruguai, Paraná, Sinos and Jacuí no Brasil. Os seguintes resultados foram obtidos: (i) Região do DNAmt usada NADH2; (ii) Tamanho do amplicons= 432 pb; (iii) 5 populações; (iv) 63 espécimes avaliadas; (v) diversidade haplotípica total (b) = $31,6 \%$; (vi) divergência nucleotídica $(\pi)=0,132 \%$; (vii) índice de divergência populacional entre populações $\Phi_{S T}=0.12$.

Santos et al. (2007), testaram a hipótese de que as populações de tambaqui (Colossoma macropomum) no Rio Amazonas fossem representadas por um único estoque genético. Este importante trabalho demonstrou a utilidade das metodologias moleculares para o manejo de espécies de peixes de importância econômica na região Amazônica. Os seguintes resultados foram obtidos: (i) Região do DNAmt usada D-loop; (ii) Tamanho do amplicons=1,077 kb; (iii) 
5 populações; (iv) 48 espécimes avaliadas; (v) diversidade haplotípica total $(b)=99,9 \%$; (vi) divergência nucleotídica $(\pi)=1,2 \%$; (vii) índice de divergência populacional entre populações $\Phi_{S T}=-0,0099$.

Morelli et al. (2007), avaliaram populações de P. lineatus do rio Mogi-Guaçu coletados nas épocas de chuvas (julho a setembro) e chuvas (outubro a janeiro) e ao contrário de outros trabalhos com esta espécie, os autores encontram diferenciação genética entre populações. Os seguintes resultados foram obtidos: (i) Região do DNAmt usada D-loop; (ii) Tamanho do amplicons= não informado; (iii) 2 populações (residentes e migrantes); (iv) 74 espécimes avaliadas; (iii) diversidade haplotípica total $(h)=97,7 \%$ (residente), 97,0\% (migrante); (iv) divergência nucleotídica $(\pi)$ não informado; (iv) índice de divergência populacional entre populações $\Phi_{\mathrm{ST}}=0,076$.

Farias et al. (2010), propuseram que as corredeiras que separam a região Amazônica brasileira da sub-bacia Amazônica Boliviana não são suficientes para impedir o fluxo gênico de populações de tambaqui (C. macropomum). Este trabalho apresentou resultados com importantes implicações no que se refere à construção de barragens na região estudada. Os seguintes resultados foram obtidos: (i) Região do DNAmt usada D-loop; (ii) Tamanho do amplicon 733 pb; (iii) 14 populações do Brasil, Bolivia e Peru; (iv) 235 espécimes avaliadas; (v) diversidade haplotípica total $(h)$ = não informada; (vi) divergência nucleotídica $(\pi)$ não informada; (vii) índice de divergência populacional entre populações $\Phi_{S T}=0,0153$.

Iervolino et al. (2010), avaliaram a hipótese de panmixia de populações de pacu (Piaractus mesopotamicus - 11.042,0 t - MPA, 2010) um importante peixe para pesca na região da bacia do rio Paraguai. Os seguintes resultados foram obtidos: (i) Região do DNAmt usada D-loop; (ii) Tamanho do amplicon 635 pb; (iii) 10 populações; (iv) 99 espécimes avaliadas; (v) diversidade haplotípica total $(h)=84 \%$; (vi) divergência nucleotídica $(\pi)=1,3 \%$; (vii) índice de divergência populacional entre populações $\Phi_{S T}=-0.0012$.

Dois trabalhos com espécies amazônicas de interesse para aquarofilia foram publicados com sequenciamento de regiões do DNAmt. Espécies nativas da região Amazônica têm sido alvos de intensa captura devido ao seu comércio dentro e fora do Brasil (GERSTNER et al., 2006). O primeiro trabalho, sugere a presença de duas populações provenientes dos rios Negro e Uatumã da espécie Carnegiella strigata, conhecida como borboleta marmorada, apresentam profunda diferenciação genética (SCHNEIDER et al., 2012). Os seguintes resultados foram obtidos: (i) Região do DNAmt usada ATPase 5/6; (ii) Tamanho do amplicon 646 pb; (iii) 2 populações; (iv) 135 espécimes avaliadas; (v) diversidade haplotípica total (b) = não informado; 
(vi) divergência nucleotídica $(\pi)$ = não informado; (vii) índice de divergência populacional entre populações $\Phi_{C T}=0,90$. O segundo trabalho avaliou populações da espécie Nannostomus eques, conhecida como peixe-lápis (TERENCIO et al., 2012). Aqui também foi verificada uma forte estruturação populacional. Os seguintes resultados foram obtidos: (i) Região do DNAmt usada D-Loop; (ii) Tamanho do amplicon 1,087 kb; (iii) 8 populações; (iv) 125 espécimes avaliadas; (v) diversidade haplotípica total $(h)=99,9 \%$; (vi) divergência nucleotídica $(\pi)=2,39 \%$; (vii) índice de divergência populacional total entre populações $\Phi_{\mathrm{CT}}=0,9187$.

Silva et al. (2013), avaliaram a variação do DNAmt da espécie Salminus hillari, conhecida como tabarana. S. hillari é uma espécie de ampla distribuição em rios das bacias do Paraná, Paraguai e São Francisco, particularmente, na bacia do Paraná, onde é encontrada praticamente em toda região Alto Paraná. Não há indicativos de uma pesca comercial voltada para esta espécie, a não ser a pesca esportiva. Devido a sua seletividade ambiental, $S$. billari é geralmente utilizada como uma espécie indicadora da qualidade do ambiente (LIMA-JR. et al., 2006). O estudo avaliou uma possível estrutura genética de algumas populações desta espécie como resultado da fragmentação ambiental ocasionada por ações antrópicas. Os resultados de diferenciação populacional corroboraram esta hipótese. Os seguintes resultados foram obtidos: (i) Região do DNAmt usada D-Loop; (ii) Tamanho do amplicon 517kb; (iii) 4 populações; (iv) 79 espécimes avaliadas; (v) diversidade haplotípica total $(h)=95,5 \%$; (vi) divergência nucleotídica $(\pi)=1,1 \%$; (vii) índice de divergência populacional total entre populações $\Phi_{S T}=0,194$.

A ordem dos Siluriformes representa um grupo expressivo de espécies, cerca de 2.400 espécies (Nelson, 2006), sendo a maioria dessas ocorrem em águas doces da região neotropical. Os representantes desta ordem são chamados de peixes de couro ou bagres. Representantes desta ordem são alvos da pesca comercial e esportiva nas grandes bacias hidrográficas da América latina. Os grandes bagres migradores da região Amazônica, tais como Brachyplatystoma rousseauxii (dourada), B. vaillantii (piramutaba), B. filamentosum (piraíba clara) e B. capapretum (filhote capa preta) são capturados por pescadores no Brasil, Colômbia, Peru e Bolívia, com uma estimativa de 30.000 t/ano (FAO-COPESCAL, 2000). Na região do pantanal mato-grossense verifica-se o mesmo com as espécies pintado (P. corruscans) (25,7\%), cachara P. fasciatum com 44,8\% do desembarque total na região em 2007(CATELLA et al., 2008).

A importância das espécies de bagres para pesca e aquicultura tem despertado a atenção de grupos de pesquisa em genética de peixes para estudos genético populacionais deste grupo. Trabalhos ainda não publicados foram realizados em nível de mestrado e doutorado pelos grupos 
do INPA e da Universidade Federal do Amazonas com DNAmt (FORMIGA-AQUINO, 2003; BATISTA, 2010).

Dos trabalhos publicados em revistas científicas com a utilização de comparações de sequências mitocondriais para avaliação genética populacional, Batista e Alves-Gomes (2006), estudaram populações da espécie B. rousseauxii em três áreas de pesca distintas no canal dos rios Solimões-Amazonas. Os resultados mostram que as populações estudadas são geneticamente distintas. Os seguintes resultados foram obtidos: (i) Região do DNAmt usada D-Loop; (ii) Tamanho do amplicon 1,037 kb; (iii) 3 populações; (iv) 45 espécimes avaliadas; (v) diversidade haplotípica total $(b)=37,5 \%$; (vi) divergência nucleotídica $(\pi)=0,0703 \%$; (vii) índice de divergência populacional total entre populações $\Phi_{S T}=0,100$.

Huergo et al. (2011), avaliaram duas espécies do grupo dos grandes bagres a bacia amazônica, as espécies B. filamentosum e a B. capapretum. O trabalho não calculou qualquer índice de diferenciação genética para inferir possíveis diferenças entre as populações estudadas. Os seguintes resultados foram obtidos: (i) Região do DNAmt usada D-Loop; (ii) Tamanho do amplicon 1,03 kb; (iii) 14 populações; (iv) 337 espécimes avaliadas - 225 para B. filamentosum e 112 para B. capapretum; (v) diversidade haplotípica total $(b)=98,7 \%$ para B. filamentosum e 95,9\% para B. capapretum; (vi) divergência nucleotídica $(\pi)=1,18 \%$ para B. filamentosum e $0,41 \%$ para B. capapretum; (vii) índice de divergência populacional total entre populações não calculado.

Vilar (2012), estudou as populações remanescentes de uma espécie de bagre - o surubim do Paraíba do Sul (Steindachneridion parabybae) - endêmico da bacia do Paraíba do Sul. Esta espécie está classificada como criticamente ameaçada na Lista Nacional das Espécies de Vertebrados Aquáticos e Peixes Ameaçados de Extinção (ROSA; LIMA, 2008). É importante salientar que Machado e Abreu (1952) em levantamento das espécies comerciais pescadas no Paraíba do Sul paulista registrou uma captura de 1,5 t desta espécie em 1950. No presente estudo apenas duas populações remanescentes foram avaliadas após dois anos de levantamentos na região. Os seguintes resultados foram obtidos: (i) Região do DNAmt usada D-Loop; (ii) Tamanho do amplicon 1,0 kb; (iii) 2 populações; (iv) 46 espécimes avaliadas; (v) diversidade haplotípica total (b) $=95,6 \%$; (vi) divergência nucleotídica $(\pi)=0,968 \%$; (vii) índice de divergência populacional total entre populações $\Phi_{S T}=0,469$.

Da ordem dos Cyprinodontiformes foram avaliadas duas espécies quanto suas estruturas populacionais. Morales et al. (2011), estudaram os efeitos da fragmentação ambiental sobre a diversidade genética populacional de uma espécie endêmica (Orestias ascotanensis) da região das Salinas de Ascotán no norte do Chile. O estudo mostrou profunda diferenciação genética entre as 
populações avaliadas. Os seguintes resultados foram obtidos: (i) Região do DNAmt usada DLoop; (ii) Tamanho do amplicon 920 pb; (iii) 11 populações; (iv) 273 espécimes avaliadas; (v) diversidade haplotípica total $(b)=87 \%$; (vi) divergência nucleotídica $(\pi)=3,9 \%$; (vii) índice de divergência populacional total entre populações $\Phi_{S T}=0.46$. A segunda espécie, Rivulus hartii, nativa de Trinidade e Tobago, foi usada como modelo para testar a hipótese de colonização e diferenciação em ilhas devido à hipotética incapacidade desta espécie em colonizar ilhas separadas por um largo espectro de variações ambientais (WALTER et al., 2011). Dois marcadores foram usados, microssatélite e DNAmt. No caso do DNAmt, a diferenciação das populações foi pronunciada. O estudo mostrou profunda diferenciação genética entre as populações avaliadas. Os seguintes resultados foram obtidos: (i) Região do DNAmt usada COI; (ii) Tamanho do amplicon 800 pb; (iii) 18 populações; (iv) 79 espécimes avaliadas; (v) diversidade haplotípica total $(b)=$ não calculado; (vi) divergência nucleotídica $(\pi)=0,6 \%$; (vii) índice de divergência populacional total entre populações $\Phi_{S T}=0,368$.

Da ordem dos Perciformes, dois trabalhos de diferenciação populacional com representantes da família Cichlidae foram realizados. Carvajal-Vallejos et al. (2011), avaliaram a estrutura populacional da espécie Cichla pleiozona (tucurané) das cabeceiras do Rio Madeira na Amazônia boliviana. O trabalho utilizou sequências de um marcador nuclear e de DNAmt, com o primeiro não foi evidenciada diferenciação genética entre algumas das populações, enquanto com o DNAmt foi observado diferenciação entre todas as populações avaliadas. Os seguintes resultados foram obtidos: (i) Região do DNAmt usada D-loop; (ii) Tamanho do amplicon não informado; (iii) 6 populações; (iv) 67 espécimes avaliadas; (v) diversidade haplotípica total $(b)=$ 89,66\%; (vi) divergência nucleotídica $(\pi)=1,03 \%$; (vii) índice de divergência populacional total entre populações $\Phi_{S T}=0,4482$. No segundo trabalho, com uma espécie de cará (Gymnogeophagus gymnogenys) com ampla distribuição na região neotropical, avaliou-se os padrões de diferenciação genética entre lagoas na região da bacia do Rio da Prata entre o Uruguai e Brasil (PEREYRA; GARCÍA, 2008). Os resultados mostraram intensa diferenciação populacional entre as localidades amostradas. Os seguintes resultados foram obtidos: (i) Região do DNAmt usada Cyt b; (ii) Tamanho do amplicon $571 \mathrm{pb}$; (iii) 10 populações; (iv) 28 espécimes avaliadas; (v) diversidade haplotípica total $(b)=99,3 \%$; (vi) divergência nucleotídica $(\pi)$ = não calculada; (vii) índice de divergência populacional total entre populações $\Phi_{S C}=0.658$.

Dentro da ordem Osteoglossiformes, a família Osteoglossidae possui um importante representante, a espécie Araipama gigas. Esta é uma espécie de grande porte e nativa dos rios da região Amazônica que tem sido intensamente capturada desde o século XIX (FERRARIS, 2003). Hrbek et al. (2005), estudaram a diferenciação genética populacional de estoques de pirarucu ao 
longo do rio Amazonas e tributários. O trabalho sugere que os níveis significativos de diferenciação genética podem não ser resultado de uma real estruturação genética entre as populações, e sim resultado de atividades antrópicas que exerceram e vem exercendo diminuição das populações de pirarucu na bacia Amazônica. Os seguintes resultados foram obtidos: (i) Duas regiões parciais do DNAmt foram usadas: NADH1 e ATPase; (ii) Tamanho do amplicon 1,204 kb para o trecho NADH1 e 1,143 Kb para o trecho da ATPase; (iii) 8 populações; (iv) 139 espécimes avaliadas; (v) diversidade haplotípica total $(b)=32,62 \%$; (vi) divergência nucleotídica $(\pi)=$ não calculada; (vii) índice de divergência populacional total entre populações $\Phi_{S T}=0.447$.

\subsubsection{Discussão sobre marcadores baseados no DNA mitocondrial}

A revisão realizada para identificar trabalhos de genética populacional com peixes neotropicais mostrou que a maioria dos estudos foi realizada a partir do ano 2000. Billington e Hebert (1991), em revisão sobre o tema apresentou resultados de análises populacionais de 40 espécies de peixes. Estes autores afirmaram que até a década de 1990, os marcadores protéicos realizaram de forma eficiente o papel de discriminar populações, porém, para alguns trabalhos tal discriminação genética havia falhado. O uso da variação do DNAmt abria naquele momento uma nova perspectiva de identificação de populações. Isto foi corroborado pelo fato de que o DNAmt apresenta um quarto do tamanho efetivo genético populacional $(\mathrm{Ne})$ em relação ao genoma nuclear. Este Ne reduzido faz com que DNAmt seja mais sensível para detectar reduções da variabilidade genética devido a fenômenos de efeito fundador, diminuição populacional por ações naturais ou antrópicas ou mesmo efeitos vicariantes principalmente não naturais (FERGUNSON; DANZMANN, 1998). O habilidade de discriminar populações com o uso do DNAmt não se baseia apenas na taxa mais rápida de evolução da molécula - cerca de $2 \%$ por milhão de anos (BROWN, 1983), mas deve ser considerado também o polimorfismo do DNAmt pré-existente na população, pois a divergência entre populações pode surgir por efeitos amostrais associado a efeito fundador da população (BERNATCHEZ et al., 1989)

De forma geral, o uso do polimorfismo do DNAmt também tem sido utilizado em outros animais de criação (LOFTUS et al., 1994). Além do seu uso para identificar populações ou estoques, a variação do DNAmt pode ser útil para: (i) estabelecer as relações entre espécies domésticas e seus parentes selvagens; (ii) identificar locais de domesticação; (iii) conhecer a origem materna de populações (LENSTRA et al., 2012). Moritz (1994), salientou que as variações presente no DNAmt podem ser utilizadas para a conservação genética que tem como objetivo identificar e manejar apropriadamente a diversidade genética e para estudos demográficos úteis para o manejo a curto prazo de populações. 
O poder para detectar as variações dentro e entre populações com o uso do RFLP ou sequenciamento direto de regiões específicas é um tema de controvérsia (FERGUNSON; DANZMANN, 1998). A escolha da região a ser avaliada é fundamental para os resultados a serem alcançados na identificação de populações. As taxas evolutivas variam entre as diversas regiões do DNAmt. Cada região codificadora possui sua própria taxa evolutiva que depende das restrições funcionais do gene e de sua composição de bases (MEYER, 1993). A região controle do DNAmt conhecida como D-loop em razão da formação de uma alça no momento da replicação do DNAmt, é a região mais variável de todo genoma mitocondrial. A taxa de evolução do D-loop é de 2 a 5 vezes maior do que os genes codificadores de proteínas (AQUADRO; GREENBER, 1983). Em razão desta característica, esta região é a mais indicada para estudos populacionais, especificamente na primeira metade do D-loop mitocondrial a partir do gene do RNA transportador da prolina, pois esta é a região com maior taxa de substituição nucleotídica, e por isso mais adequada para estudos comparativos intraespecíficos (LEE et al., 1995).

Para entender melhor os resultados e a abrangência dos estudos com DNAmt em peixes neotropicais, a seguinte tabela foi elabora de forma a resumir os principais resultados em ordem de publicação gerados pelos estudos por RFLP e sequenciamento (Tabela 7).

Tabela 7. Resumo dos trabalhos genético populacional de peixes neotropicais com o uso do DNAmt

\begin{tabular}{|c|c|c|c|c|c|c|c|}
\hline Espécie & NC & $\mathbf{R U}$ & $\mathbf{T}$ & 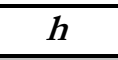 & $\pi$ & $\Phi$ & Ref. \\
\hline Bycon opalinus & $\begin{array}{l}\text { Pirapitinga } \\
\text { do sul }\end{array}$ & $\begin{array}{l}\text { DNAmt } \\
\text { integral } \\
\text { RFLP }\end{array}$ & $\begin{array}{c}16,3 \\
\mathrm{~kb}\end{array}$ & $60,0 \%$ & $0,825 \%$ & 0,281 & $\begin{array}{l}\text { Hilsdorf et. al. } \\
\text { (2002) }\end{array}$ \\
\hline $\begin{array}{c}\text { Astyanax } \\
\text { altiparanae }\end{array}$ & lambari & $\begin{array}{l}\text { DNAmt } \\
\text { integral } \\
\text { RFLP }\end{array}$ & - & $53,3 \%$ & $0,156 \%$ & - & $\begin{array}{c}\text { Moyés e } \\
\text { Almeida- } \\
\text { Toledo, (2002) }\end{array}$ \\
\hline A. fasciatus & lambari & $\begin{array}{l}\text { DNAmt } \\
\text { integral } \\
\text { RFLP }\end{array}$ & - & $80,0 \%$ & $0,286 \%$ & - & $\begin{array}{c}\text { Moyés e } \\
\text { Almeida- } \\
\text { Toledo, (2002) }\end{array}$ \\
\hline A. lacustres & lambari & $\begin{array}{c}\text { DNAmt } \\
\text { integral } \\
\text { RFLP }\end{array}$ & - & $73,3 \%$ & $0,18 \%$ & - & $\begin{array}{c}\text { Moyés e } \\
\text { Almeida- } \\
\text { Toledo, (2002) }\end{array}$ \\
\hline $\begin{array}{c}\text { A. scabripinnis } \\
\text { paranae }\end{array}$ & lambari & $\begin{array}{l}\text { DNAmt } \\
\text { integral } \\
\text { RFLP }\end{array}$ & - & $16,6 \%$ & $0,11 \%$ & - & $\begin{array}{c}\text { Moyés e } \\
\text { Almeida- } \\
\text { Toledo, (2002) }\end{array}$ \\
\hline A. schubarti & lambari & $\begin{array}{l}\text { DNAmt } \\
\text { integral } \\
\text { RFLP }\end{array}$ & - & $64,0 \%$ & $0,24 \%$ & - & $\begin{array}{c}\text { Moyés e } \\
\text { Almeida- } \\
\text { Toledo, (2002) }\end{array}$ \\
\hline Leporinus elongatus & piapara & $\begin{array}{l}\text { D-loop } \\
\text { Seq. }\end{array}$ & $\begin{array}{l}1,3 \\
\mathrm{~kb}\end{array}$ & $\begin{array}{c}95,80 \\
\%\end{array}$ & $3,51 \%$ & - & $\begin{array}{c}\text { Martins et al. } \\
\text { (2003) }\end{array}$ \\
\hline $\begin{array}{c}\text { Brachyplatystoma } \\
\text { flavicans }\end{array}$ & dourada & $\begin{array}{c}\text { ND5/6 } \\
\text { Cytb } \backslash \mathrm{D}- \\
\text { loop } \\
\text { RFLP }\end{array}$ & $\begin{array}{l}4,65 \\
\mathrm{~kb}\end{array}$ & $60,9 \%$ & $6,35 \%$ & - & $\begin{array}{l}\text { Coronel et al. } \\
\text { (2004) }\end{array}$ \\
\hline
\end{tabular}


Tabela 7. Continuação

\begin{tabular}{|c|c|c|c|c|c|c|c|}
\hline Espécie & NC & $\mathbf{R U}$ & $T$ & $\boldsymbol{h}$ & $\pi$ & $\Phi$ & Ref. \\
\hline $\begin{array}{c}\text { Pseudoplatystoma } \\
\text { Fasciatum }\end{array}$ & cachara & $\begin{array}{c}\mathrm{ND} 5 / 6 \\
\mathrm{Cytb} \backslash \mathrm{D}- \\
\text { loop } \\
\text { RFLP }\end{array}$ & $\begin{array}{l}4,65 \\
\mathrm{~kb}\end{array}$ & $\begin{array}{c}24,5 \\
\%\end{array}$ & $0,9 \%$ & 0,146 & $\begin{array}{c}\text { Coronel et al. } \\
(2004)\end{array}$ \\
\hline Arapaima gigas & pirarucu & $\begin{array}{l}\text { NADH1 } \\
\text { ATPase } \\
\text { seq }\end{array}$ & $\begin{array}{c}2,34 \\
\mathrm{~kb}\end{array}$ & $\begin{array}{c}32,62 \\
\%\end{array}$ & - & 0,44 & $\begin{array}{l}\text { Hrbek et al. } \\
\text { (2005) }\end{array}$ \\
\hline Salminus brasiliensis & dourado & $\begin{array}{l}\text { NADH2 } \\
\text { Seq. }\end{array}$ & $\begin{array}{l}432 \\
\mathrm{pb}\end{array}$ & - & - & 0,015 & $\begin{array}{l}\text { Machado et al. } \\
\text { (2005) }\end{array}$ \\
\hline B. rousseauxii & dourada & $\begin{array}{l}\text { D-Loop } \\
\text { seq }\end{array}$ & $\begin{array}{l}1,03 \\
\mathrm{~kb}\end{array}$ & $\begin{array}{c}37,5 \\
\%\end{array}$ & $0,07 \%$ & 0,010 & $\begin{array}{c}\text { Batista e } \\
\text { Alves-Gomes } \\
\text { (2006) }\end{array}$ \\
\hline $\begin{array}{c}\text { Colossoma } \\
\text { macropomum }\end{array}$ & tambaqui & $\begin{array}{l}\text { D-loop } \\
\text { Seq. }\end{array}$ & $\begin{array}{l}1,07 \\
\mathrm{~kb}\end{array}$ & $\begin{array}{l}99,9 \\
\%\end{array}$ & $1,2 \%$ & $-0,009$ & $\begin{array}{l}\text { Santos et al. } \\
\text { (2007) }\end{array}$ \\
\hline Prochilodus lineatus & curimbatá & $\begin{array}{l}\text { D-loop } \\
\text { Seq. }\end{array}$ & - & $\begin{array}{c}97,0 \\
\%\end{array}$ & - & 0,076 & $\begin{array}{l}\text { Morelli et al. } \\
\quad(2007)\end{array}$ \\
\hline $\begin{array}{c}\text { Gymnogeophagus } \\
\text { gymnogenys }\end{array}$ & cará & $\begin{array}{l}\text { Cyt b } \\
\text { seq }\end{array}$ & $\begin{array}{l}571 \\
\mathrm{pb}\end{array}$ & $\begin{array}{c}99,3 \\
\%\end{array}$ & - & 0.65 & $\begin{array}{c}\text { Pereyra e } \\
\text { García, (2008) }\end{array}$ \\
\hline C. macropomum & tambaqui & $\begin{array}{l}\text { D-loop } \\
\text { Seq. }\end{array}$ & $\begin{array}{l}733 \\
\mathrm{pb}\end{array}$ & - & - & 0,015 & $\begin{array}{l}\text { Farias et al. } \\
\text { (2010) }\end{array}$ \\
\hline $\begin{array}{c}\text { Piaractus } \\
\text { mesopotamicus }\end{array}$ & pacu & $\begin{array}{l}\text { D-loop } \\
\text { Seq. }\end{array}$ & $\begin{array}{l}635 \\
\mathrm{pb}\end{array}$ & $84 \%$ & $1,3 \%$ & $\begin{array}{c}-0.00 \\
1\end{array}$ & $\begin{array}{l}\text { Iervolino et al. } \\
\qquad(2010)\end{array}$ \\
\hline B. capapretum & $\begin{array}{l}\text { piraíba } \\
\text { escura }\end{array}$ & $\begin{array}{l}\text { D-Loop } \\
\text { seq }\end{array}$ & $\begin{array}{l}1,03 \\
\mathrm{~kb}\end{array}$ & $\begin{array}{c}95,9 \\
\%\end{array}$ & $0,41 \%$ & - & $\begin{array}{l}\text { Huergo et al. } \\
\qquad(2011)\end{array}$ \\
\hline $\begin{array}{c}\text { Orestias } \\
\text { ascotanensis }\end{array}$ & - & $\begin{array}{l}\text { D-Loop } \\
\text { seq }\end{array}$ & $\begin{array}{l}920 \\
\mathrm{pb}\end{array}$ & $87 \%$ & $3,9 \%$ & 0.46 & $\begin{array}{l}\text { Morales et al. } \\
\text { (2011) }\end{array}$ \\
\hline Rivulus hartii & - & $\begin{array}{l}\text { COI } \\
\text { seq }\end{array}$ & $\begin{array}{c}800 \\
\mathrm{pb}\end{array}$ & - & $0,6 \%$ & 0,36 & $\begin{array}{l}\text { Walter et al. } \\
\qquad(2011)\end{array}$ \\
\hline Cichla pleiozona & tucurané & $\begin{array}{l}\text { D-Loop } \\
\text { seq }\end{array}$ & - & $\begin{array}{c}89,6 \\
\%\end{array}$ & $1,03 \%$ & 0,44 & $\begin{array}{c}\text { Carvajal- } \\
\text { Vallejos et al. } \\
\text { (2011) }\end{array}$ \\
\hline Prochilodus lineatus & curimbatá & $\begin{array}{l}\text { D-loop } \\
\text { RFLP }\end{array}$ & $\begin{array}{l}1,37 \\
\mathrm{~kb}\end{array}$ & $\begin{array}{l}77,21 \\
\%\end{array}$ & $1,6 \%$ & $-0,007$ & $\begin{array}{l}\text { Garcez et al. } \\
\text { (2011) }\end{array}$ \\
\hline B. filamentosum & Piraíba & $\begin{array}{l}\text { D-Loop } \\
\text { seq }\end{array}$ & $\begin{array}{l}1,03 \\
\mathrm{~kb}\end{array}$ & $\begin{array}{c}98,7 \\
\%\end{array}$ & $1,18 \%$ & - & $\begin{array}{l}\text { Huergo et al. } \\
\quad(2011)\end{array}$ \\
\hline Carnegiella strigata & $\begin{array}{l}\text { borboleta } \\
\text { marmorada }\end{array}$ & $\begin{array}{l}\text { ATPase } \\
\text { seq }\end{array}$ & $\begin{array}{c}646 p \\
b\end{array}$ & - & - & 0,900 & $\begin{array}{c}\text { Schneider et al. } \\
\text { (2012) }\end{array}$ \\
\hline Nannostomus eques & peixe-lápis & $\begin{array}{l}\text { D-Loop } \\
\text { seq }\end{array}$ & $\begin{array}{c}1,08 \\
\mathrm{~kb}\end{array}$ & $\begin{array}{c}99,9 \\
\%\end{array}$ & $2,39 \%$ & 0,918 & $\begin{array}{l}\text { Terencio et } \\
\text { al.(2012) }\end{array}$ \\
\hline $\begin{array}{c}\text { Steindachneridion } \\
\text { parahybae }\end{array}$ & $\begin{array}{l}\text { surubim do } \\
\text { Paraíba do } \\
\text { Sul }\end{array}$ & $\begin{array}{l}\text { D-Loop } \\
\text { seq }\end{array}$ & $\begin{array}{l}1,0 \\
\mathrm{~kb}\end{array}$ & $\begin{array}{l}95,6 \\
\%\end{array}$ & $0,968 \%$ & 0,46 & Vilar (2012) \\
\hline Salminus hillari & tabarana & $\begin{array}{l}\text { D-Loop } \\
\text { seq }\end{array}$ & & $\begin{array}{l}95,5 \\
\%\end{array}$ & $1,10 \%$ & 0,194 & $\begin{array}{c}\text { Silva et al. } \\
\text { (2013) }\end{array}$ \\
\hline
\end{tabular}

NC: nome comum; RU: região do DNAm utilizada; T: tamanho do genoma mitocondrial usado nas análises; $h$ : diversidade haplotípica; $\pi$ : divergência nucleotídica; $\Phi$ : índice de diferenciação genética phi. 
Uma avaliação do conjunto de trabalhos publicados com a utilização do DNAmt em relação índices de variabilidade genética e diferenciação populacional mostra uma miríade de resultados que dificulta a observação de padrões para peixes neotropicais. Apesar da maioria dos trabalhos utilizarem a região do D-loop, outros utilizam outras regiões que possuem taxas evolutivas diferentes. Mesmo os trabalhos que utilizam o D-loop geram amplicons de tamanhos diferentes o que pode gerar resultados diferentes quanto aos índices de diversidade haplotípica e divergência nucleotídica. Na tabela 8 pode ser observado que alguns trabalhos não geraram índices de diferenciação populacional o que dificulta a interpretação dos resultados quanto aos possíveis recursos genéticos populacionais existentes.

Outra questão importante é o número amostral utilizado nos trabalhos. O tamanho amostral por localidade é importante para conseguir a real distribuição dos haplótipos com o mínimo grau de confiança. Por exemplo, um tamanho amostral com 95\% de confiança significa que pelo menos um indivíduo de cada haplótipo presente na área de coleta seja detectado com um P maior ou igual a 5\%. Schwager et al. (1993), propuseram o uso da expressão (1-P $)^{\mathrm{n}}$, que é a probabilidade de não se observar um haplótipo em uma amostragem ao acaso de $\mathrm{n}$ indivíduos. Por exemplo, utilizando-se a expressão $n=\ln (1-\beta) / \ln (1-\mathrm{P})$, onde: $\beta$ é a probabilidade de se observar o haplótipo desejado e P é a probabilidade de não se observar o haplótipo desejado, teremos $\mathrm{n}=\ln (1-0.95) / \ln (1-0.05)=58.4 \sim 60$ indivíduos. Isto significa que para obtermos com 95\% de probabilidade o conjunto de haplótipos presentes na população, um tamanho amostral de 60 indivíduos por localidade se faz necessário. Este número amostral muitas vezes é impraticável para muitas espécies por questões logísticas de amostragem, bem como devido aos custos de sequenciamento das amostras.

O índice de diversidade haplotípica (b) mede a variabilidade genética dentro das populações, é a medida similar da heterozigosidade para o genoma nuclear. O valor $b$ gera informações sobre o número de haplótipos compartilhados (AVISE, 2004). Uma alta similaridade entre haplótipos indica que eles podem ter se originado recentemente de um haplótipo ancestral comum a todos eles, já níveis elevados de diversidade haplotípica pode sugerir um tempo maior de divergência desde o aparecimento dos primeiros haplótipos desta população (BILLINGTON; HEBERT, 1991).

A divergência nucleotídica $(\pi)$ mede a média de divergência entre sequências do DNA, isto é, se uma dada população exibe uma história populacional antiga (muitas substituições entre haplótipos) ou recente (poucas substituições entre haplótipos). Um valor de $\pi=0$ significa que todos os membros da população são geneticamente idênticos. Para peixes o valor de $\pi$ raramente excedem 5\% (HELFMAN et al., 2009). Doze diferentes espécies de peixes de água doce do 
hemisfério norte citados por Billington e Hebert (1991), geraram um valor médio de 2,7\% de divergência nucleotídica, já para 21 espécies de peixes de água doce neotropical o valor foi de 1,5\%. Estes valores parecem contraditórios já que a variação do DNAmt está relacionada a eventos geológicos, com valores menores de divergência em espécies do hemisfério norte devido a processos de diminuição populacionais em refúgios glaciais e maiores em regiões menos afetadas pelos períodos glaciais. Contudo, como dito esta comparação não pode ser feita diretamente a não ser que os estudos tenham sido padronizados.

Grant e Bowen (1998), propuseram quatro categorias para interpretar os índices de diversidade haplotípica $(b)$ e divergência nucleotídica $(\pi)$ conjuntamente.

Tabela 8. Categorias para interpretação de $(b)$ e $(\pi)$.

\begin{tabular}{cll}
\hline \multicolumn{1}{c}{ Pequeno } & \multicolumn{1}{c}{ G } \\
\hline Pequeno & \multicolumn{1}{c}{$\begin{array}{c}\text { Grande } \\
\text { 1. Recente gargalo populacional ou } \\
\text { efeito fundador por um único ou } \\
\text { poucas linhagens mitocondriais. }\end{array}$} & $\begin{array}{l}\text { 2. Efeito gargalo populacional seguido } \\
\text { por rápida expansão e acúmulo de } \\
\text { mutações. }\end{array}$ \\
& $\begin{array}{l}\text { 3. Divergência entre populações } \\
\text { geograficamente subdivididas. }\end{array}$ & $\begin{array}{l}\text { 4. População estável e grande com } \\
\text { uma longa história evolutiva ou com } \\
\text { contato secundários entre linhagens } \\
\text { diferentes. }\end{array}$ \\
\hline
\end{tabular}

O desenvolvimento de pacotes computacionais para análise de sequências, integrados com análises de variabilidade genética possibilitou uma melhor interpretação e quantificação das diferenças interpopulacional. A AMOVA (EXCOFFIER et al., 1992) com o uso do pacote Arlequin incorporou a frequências e a divergência dos haplótipos entre as populações para gerar um índice $\Phi$, que pode ser interpretado da mesma forma que o $F_{S T}$. No levantamento dos trabalhos com peixes neotropicais, nem todos os estudos geraram índices de diferenciação populacional. Das 27 espécies estudadas, 18 geraram um índice $\Phi$ de diferenciação populacional que em média foi de 0,28 que sugerem que em média espécies de água doce neotropical apresentam estruturação genética. É importante salientar que tal estruturação medida pelo DNAmt é aquela mediada pelos processo de conectividade genética das fêmeas. Novamente, não podemos generalizar este resultado já que as espécies neotropicais apresentam diferentes comportamentos biológicos e ocupam ambientes de água doce, geologicamente diversos na região neotropical. 


\subsubsection{RAPD (Random Amplified Polymorphic DNA)}

A técnica do RADP surgiu no início da década de 1990 como uma alternativa rápida e sem conhecimento prévio do genoma para estudar níveis de variabilidade intra e interpopulacional (WILLIAMS et al., 1990; WELSH; MCCLELLAND, 1990). As facilidades atribuídas a este marcador, tais como simplicidade técnica e extenso polimorfismo fizeram com que esta técnica fosse muito utilizada em trabalhos com peixes de água doce neotropical. $\mathrm{O}$ presente levantamento verificou 35 trabalhos que usaram o RAPD seja para avaliações da variabilidade genética de populações selvagens ou de cativeiro, ou para comparação entre espécies congêneres.

Em razão dos diferentes tipos de abordagens e falta de padronização nos cálculos dos índices clássicos de diferenciação populacional, aliada ao fato dos problemas de reprodutibilidade deste marcador (ver discussão mais adiante), o conjunto de trabalhos com a utilização do RAPD foi descrito em uma tabela resumo com as principais características de cada um (Tabela 9). 
Tabela 9. Tabela resumo dos trabalhos publicados com peixes neotropicais com o marcador RAPD.

\begin{tabular}{|c|c|c|c|c|c|}
\hline Espécie/Ordem & Local & Objetivos & NI/NA/NB & ID & Referência \\
\hline $\begin{array}{l}\text { Hoplias malabaricus } \\
\text { CHA }\end{array}$ & Bacia do Alto Paraná & $\begin{array}{l}\text { Origem da população do Rio } \\
\text { Iguaçu em comparação com } \\
\text { outras localidades }\end{array}$ & $3 / 31 / 74$ & $\begin{array}{l}\text { Índice de similaridade gerado in silico } \\
\text { pelo pacote RAPDPLOT }\end{array}$ & Dergam et al. (1998) \\
\hline $\begin{array}{l}\text { Steindacbnerina } \\
\text { brevipinna } \\
\text { CHA }\end{array}$ & Bacia do Alto Paraná & $\begin{array}{c}\text { Avaliar a variabilidade e } \\
\text { distância genética entre duas } \\
\text { populações com diferenças } \\
\text { fenotípicas }\end{array}$ & $9 / 57 / 98$ & $\begin{array}{l}\text { Distância genética de Nei } \\
\text { (RAPDDIST) e Diversidade de } \\
\text { Shannon (POPGEN 1.31) }\end{array}$ & Oliveira et al. (2002) \\
\hline $\begin{array}{l}\text { Astyanax altiparanae } \\
\text { CHA }\end{array}$ & Bacia do Alto Paraná & $\begin{array}{c}\text { Avaliar populações a montante } \\
\text { e a jusante das cataratas do } \\
\text { Iguaçu }\end{array}$ & $10 / 36 / 79$ & $\begin{array}{c}\text { Distância genética de Nei } \\
\text { (RAPDDIST) e Diversidade de } \\
\text { Shannon (POPGEN 1.31) } \\
F_{\text {ST }}=0,068 \text { (RAPDFST) }\end{array}$ & Prioli et al. (2002) \\
\hline $\begin{array}{l}\text { Brycon lundii } \\
\text { CHA }\end{array}$ & $\begin{array}{l}\text { Bacia do Rio São } \\
\text { Francisco }\end{array}$ & $\begin{array}{l}\text { Avaliar da variabilidade } \\
\text { genética em duas regiões com } \\
\text { condições ambientais distintas }\end{array}$ & $8 / 22 / 72$ & $\begin{array}{l}\text { Índice de similaridade de Jaccard e } \\
\text { variabilidade genética por frequência } \\
\text { média dos alelos } \\
\text { (NTSYS-PC 1.70) }\end{array}$ & $\begin{array}{l}\text { Wasko e Galleti Jr. } \\
\qquad(2002)\end{array}$ \\
\hline $\begin{array}{c}\text { Procbilodus marggravii } \\
\text { CHA }\end{array}$ & $\begin{array}{c}\text { Bacia do } \\
\text { Rio São Francisco }\end{array}$ & $\begin{array}{l}\text { Avaliar a variação genética na } \\
\text { área de influência do } \\
\text { reservatório de Três Marias }\end{array}$ & $10 / 56 / 31$ & $\begin{array}{l}\text { Índice de similaridade de Jaccard } \\
\text { (NTSYS-PC 1.70) }\end{array}$ & $\begin{array}{l}\text { Hatanaka e Galetti Jr. } \\
\qquad(2003)\end{array}$ \\
\hline $\begin{array}{c}\text { Astyanax altiparanae } \\
\text { CHA }\end{array}$ & Bacia do Alto Paraná & $\begin{array}{c}\text { Avaliar a estrutura genética da } \\
\text { espécie }\end{array}$ & $10 / 48 / 124$ & $\begin{array}{c}\text { Índice de similaridade de Jaccard } \\
\text { (NTSYS-PC 1.70) } \\
\text { Diversidade genotípica } \\
\text { (POPGENE 1.31) }\end{array}$ & Leuzzi et al. (2004) \\
\hline $\begin{array}{l}\text { Astyanax sp } \\
\text { CHA }\end{array}$ & $\begin{array}{c}\text { Bacia do Alto Paraná } \\
\text { Rio Tibagi }\end{array}$ & $\begin{array}{l}\text { Avaliar a variação genética } \\
\text { intra e interpopulacional }\end{array}$ & $6 / 36 / 33$ & $\begin{array}{l}\text { Îndice de similaridade de Jaccard } \\
\text { (NTSYS-PC 1.70) }\end{array}$ & Matoso et al. (2004) \\
\hline $\begin{array}{l}\text { Brycon cephalus } \\
\text { CHA }\end{array}$ & Bacia Amazônica & $\begin{array}{c}\text { Avaliação genética de um } \\
\text { estoque selvagem e três } \\
\text { cultivados }\end{array}$ & 6/99/104 & $\begin{array}{l}\text { Índice de similaridade de Jaccard } \\
\text { (NTSYS-PC 1.70) }\end{array}$ & Wasko et al .(2004) \\
\hline $\begin{array}{c}\text { Brycon moorei } \\
\text { Brycon henna } \\
\text { Colossoma macropomum } \\
\text { Piaractus brachypomus } \\
\text { CHA } \\
\end{array}$ & Bacia Amazônica & $\begin{array}{l}\text { Avaliação taxonômica e } \\
\text { genética entre populações } \\
\text { selvagens e cultivadas. }\end{array}$ & $6 / 105 / 2129$ & $\begin{array}{l}\text { Distância Genética } \\
\text { de Nei e Li (1979) }\end{array}$ & $\begin{array}{l}\text { Pineda-Santis et al. } \\
\qquad\left(2004_{\mathrm{a}}\right)\end{array}$ \\
\hline
\end{tabular}




\section{Tabela 9. Continuação}

\begin{tabular}{|c|c|c|c|c|c|}
\hline Espécie/Ordem & Local & Objetivos & NI/NA/NB & ID & Referência \\
\hline $\begin{array}{c}\text { Piaractus brachypomus } \\
\text { CHA }\end{array}$ & Bacia Amazônica & $\begin{array}{l}\text { Avaliação genética de estoques } \\
\text { cultivados }\end{array}$ & $6 / 20 / 666$ & $\begin{array}{l}\text { Distância Genética } \\
\text { de Nei e Li (1979) }\end{array}$ & $\begin{array}{l}\text { Pineda-Santis et al. } \\
\qquad\left(2004_{b}\right)\end{array}$ \\
\hline $\begin{array}{c}\text { Astyanax bimaculatus } \\
\text { CHA }\end{array}$ & $\begin{array}{l}\text { Bacia do Rio Doce } \\
\text { (MG) }\end{array}$ & $\begin{array}{l}\text { Avaliar a variabilidade genética } \\
\text { e estrutura populacional }\end{array}$ & $6 / 300 / 28$ & $\begin{array}{l}\text { AMOVA } \\
\Phi_{S T}=0,177\end{array}$ & Paiva et al. (2006) \\
\hline $\begin{array}{c}\text { Astyanax scabripinnis } \\
\text { CHA }\end{array}$ & Bacia do alto Paraná & $\begin{array}{l}\text { Avaliar variabilidade genética e } \\
\text { estrutura da população }\end{array}$ & $10 / 30 / 159$ & $\begin{array}{c}\text { Distância genética de Nei } \\
\text { (TFPGA 1.3) } \\
\text { G } \\
\text { IT }=0,062 \\
\text { Índice de Jaccard (NTSYS-PC) }\end{array}$ & Sofia et al. (2006) \\
\hline $\begin{array}{l}\text { Pimelodus maculatus } \\
\text { Prochilodus lineatus } \\
\text { Salminus brasiliensis } \\
\text { Steindachneridion scripta } \\
\text { CHA }\end{array}$ & Bacia do Rio Uruguai & $\begin{array}{c}\text { Avaliar a variabilidade genética } \\
\text { nas espécies citadas }\end{array}$ & $\begin{array}{c}11 / 13-11-22-13 / 11-29- \\
45-33\end{array}$ & $\begin{array}{l}\text { Indice de similaridade de Jaccard } \\
\text { (NTSYS-PC 2.02) }\end{array}$ & Ramella et al. (2006) \\
\hline $\begin{array}{c}\text { Astyanax fasciatus } \\
\text { CHA }\end{array}$ & $\begin{array}{l}\text { Bacia do Rio Mogi } \\
\text { Guaçu }\end{array}$ & $\begin{array}{l}\text { Avaliar o fluxo gênico entre } \\
\text { diferentes citótipos da espécie }\end{array}$ & $10 / 23 / 59$ & $\begin{array}{l}\text { Identidade genética de Nei e GST } \\
\text { (Popgen 1.31) }\end{array}$ & Pazza et al. (2007) \\
\hline $\begin{array}{c}\text { Salminus brasiliensis } \\
\text { CHA }\end{array}$ & $\begin{array}{l}\text { Bacia do Rio } \\
\text { Paranapanema }\end{array}$ & $\begin{array}{l}\text { Avaliar a variabilidade e } \\
\text { estrutura genética entre regiões } \\
\text { de barramento }\end{array}$ & $12 / 87 / 192$ & $\begin{array}{l}\text { Variabilidade genética } \\
\text { (TFPGA 1.3) } \\
\text { AMOVA } \\
\Phi_{S T}=0,018\end{array}$ & Lopes et al. (2007) \\
\hline $\begin{array}{l}\text { Brycon bilarii } \\
\text { CHA }\end{array}$ & $\begin{array}{l}\text { Bacia do Rio } \\
\text { Paraguai }\end{array}$ & $\begin{array}{l}\text { Avaliar a variabilidade genética } \\
\text { entre períodos reprodutivos e } \\
\text { não reprodutivos }\end{array}$ & $3 / 80 / 32$ & $\begin{array}{c}\text { Variabilidade genética } \\
\text { Índice de diversidade de Shanon } \\
\text { AMOVA } \\
\Phi_{S T}=0.034\end{array}$ & $\begin{array}{l}\text { Sanches e Galetti Jr, } \\
\text { (2007) }\end{array}$ \\
\hline $\begin{array}{l}\text { Brycon henni } \\
\text { CHA }\end{array}$ & $\begin{array}{c}\text { Bacias dos rios } \\
\text { Magdalena e Cauca } \\
\text { Colômbia }\end{array}$ & $\begin{array}{l}\text { Avaliar a variabilidade } \\
\text { genéticaem populações } \\
\text { selvagens e de cativeiro }\end{array}$ & $35 / 60 / 1466$ & $\begin{array}{l}\text { Distância Genética } \\
\text { de Nei e Li (1979) }\end{array}$ & $\begin{array}{l}\text { Pineda-Santis et al. } \\
\qquad(2007)\end{array}$ \\
\hline $\begin{array}{l}\text { Leporinus elongates } \\
\text { CHA }\end{array}$ & $\begin{array}{l}\text { Estações de } \\
\text { piscicultura } \\
\text { SP }\end{array}$ & $\begin{array}{l}\text { Avaliar a variabilidade genética } \\
\text { de populações de cativeiro }\end{array}$ & $10 / 57 / 105$ & $\begin{array}{c}\text { Diversidade genética de Nei } \\
\text { PopGene } 1.31 \\
G_{\text {ST }}=0,088\end{array}$ & Gomes et al. (2008) \\
\hline
\end{tabular}


Tabela 9. Continuação

\begin{tabular}{|c|c|c|c|c|c|}
\hline Espécie/Ordem & Local & Objetivos & $\mathbf{N I} / \mathbf{N A} / \mathbf{N B}$ & ID & Referência \\
\hline $\begin{array}{c}\text { Mimagoniates microlepis } \\
\text { CHA }\end{array}$ & $\begin{array}{c}\text { Bacias litorâneas do } \\
\text { sudeste e sul do } \\
\text { Brasil }\end{array}$ & $\begin{array}{c}\text { Avaliar a variabilidade genética } \\
\text { de populações }\end{array}$ & $1 / 10 / 12$ & - & Torres et al. (2008) \\
\hline $\begin{array}{c}\text { Piaractus mesopotamicus } \\
\text { CHA }\end{array}$ & Rio Paranapanema & $\begin{array}{l}\text { Avaliar a variabilidade genética } \\
\text { de populações de cativeiro }\end{array}$ & $14 / 59 / 120$ & $\begin{array}{c}\text { AMOVA } \\
\Phi_{S T}=0.018\end{array}$ & Povh et al. (2008) \\
\hline $\begin{array}{l}\text { Astyanax aff. } \\
\text { bimaculatus } \\
\text { CHA }\end{array}$ & $\begin{array}{l}\text { Bacia do rio Contas } \\
\text { Bahia }\end{array}$ & $\begin{array}{l}\text { Avaliar a variabilidade e } \\
\text { estrutura genética entre regiões } \\
\text { de barramento }\end{array}$ & $6 / 73 / 28$ & $\begin{array}{c}\text { AMOVA } \\
\Phi_{S T}=0.1868\end{array}$ & Pamponet et al. (2008) \\
\hline $\begin{array}{c}\text { Brycon orbignyanus } \\
\text { CHA }\end{array}$ & $\begin{array}{l}\text { Pisciculturas de } \\
\text { Castillo e Porto } \\
\text { Ferreira da Duke } \\
\text { Energy }\end{array}$ & $\begin{array}{l}\text { Avaliar a variabilidade genética } \\
\text { de populações de cativeiro }\end{array}$ & $14 / 58 / 61$ & $\begin{array}{c}\text { Variabilidade genética } \\
\text { (TFPGA 1.3) } \\
\text { AMOVA } \\
\Phi_{S T}=0.12\end{array}$ & $\begin{array}{l}\text { Lopera-Barrero et al. } \\
\qquad\left(2008_{\mathrm{a}, \mathrm{b}}\right)\end{array}$ \\
\hline $\begin{array}{c}\text { Piaractus mesopotamicus } \\
\text { CHA }\end{array}$ & $\begin{array}{c}\text { Estações de } \\
\text { piscicultura do } \\
\text { Paraná }\end{array}$ & $\begin{array}{l}\text { Avaliar a variabilidade genética } \\
\text { de populações de cativeiro }\end{array}$ & $7 / 60 / 75$ & $\begin{array}{l}\text { Diversidade genética de } \\
\text { Shannon, } \\
\text { PopGene } 1.31\end{array}$ & Pohv et al. (2009) \\
\hline $\begin{array}{c}\text { Mimagoniates microlepis } \\
\text { CHA }\end{array}$ & $\begin{array}{c}\text { Bacias litorâneas do } \\
\text { sudeste e sul do } \\
\text { Brasil }\end{array}$ & $\begin{array}{c}\text { Avaliar a variabilidade genética } \\
\text { de populações }\end{array}$ & $6 / 100 / 111$ & $\begin{array}{c}\text { AMOVA } \\
\Phi_{S T}=0,597\end{array}$ & $\begin{array}{l}\text { Torres e Ribeiro, } \\
\qquad(2009)\end{array}$ \\
\hline $\begin{array}{c}\text { Colossoma macropomum } \\
\text { CHA }\end{array}$ & $\begin{array}{c}\text { Pisiculturas dos } \\
\text { estados de RO, Se e } \\
\text { MT }\end{array}$ & $\begin{array}{c}\text { Diversidade genética de quatro } \\
\text { estoques de diferentes regiões } \\
\text { do Brasil }\end{array}$ & $10 / 116 / 144$ & $\begin{array}{c}\text { AMOVA } \\
\Phi_{S T}=0,098\end{array}$ & Jacometo et al. (2010) \\
\hline $\begin{array}{l}\text { Brycon benni } \\
\text { CHA }\end{array}$ & $\begin{array}{c}\text { Bacias do rios Nare e } \\
\text { Guatapé } \\
\text { Colômbia }\end{array}$ & $\begin{array}{c}\text { Avaliar a variabilidade genética } \\
\text { de populações. }\end{array}$ & $14 / 195 / 66$ & $\begin{array}{c}\text { AMOVA } \\
\Phi_{S T}=0.297 \text { (Nare) } \\
\Phi_{S T}=0,163 \text { (Guatapé) }\end{array}$ & $\begin{array}{l}\text { Hurtado-Alarcón et al. } \\
\text { (2011) }\end{array}$ \\
\hline $\begin{array}{c}\text { Brycon orbignyanus } \\
\text { CHA }\end{array}$ & Bacia do alto Paraná & $\begin{array}{c}\text { Avaliar a variabilidade genética } \\
\text { em populações selvagens e de } \\
\text { cativeiro }\end{array}$ & $9 / 60 / 82$ & $\begin{array}{c}\text { AMOVA } \\
\Phi_{S T}=0.202\end{array}$ & $\begin{array}{l}\text { Panarari-Antunes et al. } \\
\text { (2011) }\end{array}$ \\
\hline $\begin{array}{c}\text { Salminus brasiliensis } \\
\text { CHA }\end{array}$ & $\begin{array}{l}\text { Bacia do rio } \\
\text { Paranapanema }\end{array}$ & $\begin{array}{l}\text { Avaliar a variabilidade genética } \\
\text { de populações de cativeiro }\end{array}$ & $8 / 50 / 96$ & $\begin{array}{c}\text { AMOVA } \\
\Phi_{S T}=0,046\end{array}$ & Gomes et al. (2011) \\
\hline $\begin{array}{l}\text { Leporinus elongates } \\
\text { CHA }\end{array}$ & $\begin{array}{c}\text { Bacia do rio } \\
\text { Paranapanema }\end{array}$ & $\begin{array}{l}\text { Avaliar variabilidade genética e } \\
\text { estrutura da população }\end{array}$ & $10 / 117 / 138$ & $\begin{array}{c}\text { AMOVA } \\
\Phi_{S T}=0,021\end{array}$ & Ramos et al. (2012) \\
\hline
\end{tabular}


Tabela 9. Continuação

\begin{tabular}{|c|c|c|c|c|c|}
\hline Espécie/Ordem & Local & Objetivos & $\mathbf{N I} / \mathbf{N A} / \mathbf{N B}$ & ID & Referência \\
\hline $\begin{array}{l}\text { Symphysodon spp. } \\
\text { PER }\end{array}$ & Bacia Amazônica & $\begin{array}{l}\text { Avaliar as relações genéticas } \\
\text { entre quatro variedades } \\
\text { selvagens e cinco de cativeiro. }\end{array}$ & $5 / 45 /-$ & $\begin{array}{c}\text { Distância Genética } \\
\text { de Nei e Li (1979) } \\
\text { Mann-Whitney U-test } \\
\text { SASversion } 6.12\end{array}$ & Koh et al. (1999) \\
\hline $\begin{array}{l}\text { Cichla monoculus } \\
\text { PER }\end{array}$ & Bacia Amazônica & $\begin{array}{l}\text { Avaliar variabilidade genética e } \\
\text { estrutura da população }\end{array}$ & $6 / 57 / 126$ & $\begin{array}{c}\text { Distância genética de Nei (1972) } \\
\text { TFPGA } 1.3 \\
G_{\mathrm{ST}}=0,2623\end{array}$ & Santos et al. (2012) \\
\hline $\begin{array}{l}\text { Iheringichthys labrosus } \\
\text { Pimelodus maculatus } \\
\text { Pimelodus cf. absconditus } \\
\text { SIR }\end{array}$ & $\begin{array}{l}\text { Bacia do Rio } \\
\text { Tibagi }\end{array}$ & $\begin{array}{c}\text { Avaliar a variabilidade genética } \\
\text { de populações }\end{array}$ & $7 / 27-16-12 / 147-95-140$ & $\begin{array}{c}\text { Índice de similaridade de Jaccard } \\
\text { (NTSYS-PC 1.70) }\end{array}$ & Almeida et al. (2001) \\
\hline $\begin{array}{l}\text { Pseudoplatystoma } \\
\text { corruscans } \\
\text { SIR }\end{array}$ & $\begin{array}{l}\text { Bacia do rio } \\
\text { Paraná }\end{array}$ & $\begin{array}{l}\text { Avaliar variabilidade genética e } \\
\text { estrutura da população }\end{array}$ & $19 / 24 / 152$ & $\begin{array}{c}F_{\text {ST }} \text { de Lynch e Milligan's (1994) } \\
\text { Distância Genética de Nei (1978) } \\
\text { (RAPDdist e RAPDFST) } \\
F_{\mathrm{ST}}=0,074\end{array}$ & Sekine et al. (2002) \\
\hline $\begin{array}{l}\text { Pimelodus maculatus } \\
\text { SIR }\end{array}$ & $\begin{array}{l}\text { Bacia do alto } \\
\text { Paraná }\end{array}$ & $\begin{array}{l}\text { Avaliar variabilidade genética e } \\
\text { estrutura da população }\end{array}$ & $15 / 30 / 210$ & $\begin{array}{l}\text { Distância genética de Nei (1978) } \\
\text { POPGENE } 1.31 \text { e TFPGA } 1.3\end{array}$ & Almeida et al. (2003) \\
\hline $\begin{array}{c}\text { Hypostomus ancistroides } \\
\text { SIR }\end{array}$ & $\begin{array}{l}\text { Bacia do rio } \\
\text { Cambé } \\
\text { Paraná }\end{array}$ & $\begin{array}{l}\text { Avaliar variabilidade genética e } \\
\text { estrutura da população }\end{array}$ & $11 / 46 / 147$ & $\begin{array}{c}\text { AMOVA } \\
\Phi_{S T}=0.091\end{array}$ & Sofia et al. (2008) \\
\hline
\end{tabular}

CHA=Characiformes; PER=Perciformes e SIR=Siruliformes - NI = No. de iniciadores utilizados; NA = Número amostral; NB = Número de bandas ID = Índice de diferenciação genético utilizado. 


\subsubsection{Discussão sobre RAPD}

A técnica do RAPD se difundiu significativamente nos anos de 1990. Sua aparente simplicidade técnica e baixo custo quando comparado a outros marcadores usados na época fez com que sua popularidade crescesse em estudos sobre mapeamento genético, genética de populações, taxonomia entre outros.

O primeiro sinal de que o uso do RAPD em estudos populacionais começou a ser questionado foi a posição de algumas revistas científicas de importância como a Molecular Ecology que em seu guia de instrução de autores recomenda que artigos com RAPD não sejam aceitos pela revista (The appropriateness of $\boldsymbol{R A P D}$ or ISSR markers for population genetic inference is increasingly questioned by our reviewers and editors because of concerns about reproducibility, dominance, and homology. Given these worries, and the ready availability of other kinds of markers that do not suffer from all of these problems, studies based primarily on $\boldsymbol{R A P D / I S S R ~ r a r e l y ~ p a s s ~ t h e ~ s c r u t i n y ~ o f ~ p e e r ~ r e v i e w ~ i n ~ M o l e c u l a r ~ E c o l o g y ) . ~ O u t r a ~}$ importante revista na área de produção de organismos aquáticos em cativeiro, Aquaculture, também deixa explícito aos autores a não aceitação de trabalhos com RAPD (Aquaculture will not accept manuscripts focusing mainly on population genetics studies that are based on $\boldsymbol{R A P D}$ and AFLP markers, since the dominance and multilocus nature of the fingerprints are not suitable for making inferences about population genetic diversity and structure).

Algumas vantagens do uso do RAPD em estudos genéticos são descritas, tais como: (i) não requer conhecimento prévio do genoma da espécie alvo para o desenho dos iniciadores; (ii) não requer hibridização com sondas; (iii) requer pequenas quantidades de DNA por reação; (iv) pode produzir grande numero de fragmentos (amplicons); (v) custo baixo quando comparado a outros marcadores. Contudo, em estudos populacionais algumas desvantagens deste marcador são evidentes, tais como: (i) são marcadores dominantes, o que não possibilita a identificação direta dos indivíduos heterozigotos; (ii) o RAPD é muito dependente das condições de PCR utilizadas, como variações nas concentrações dos reagentes, do DNA alvo, dos tempos e temperatura de ciclagem; (iii) a não hibridização entre os iniciadores e o DNA alvo pode resultar a ausência de amplicon em algumas amostras o que pode levar a uma genotipagem equivocada; (iv) problemas de co-migração, gera fragmentos de mesmo tamanho serem interpretados ao mesmo fragmento homólogo (KUMAR; GURUSUBRAMANIAN, 2011).

As dificuldades descritas acima não permitem com que o RAPD apresente reprodutibilidade dos resultados (PENNER et al., 1993; WOLFF et al., 1993). Ferguson e Danzmann (1998), destacaram este problema principalmente no que se refere à validação dos iniciadores para detectar o polimorfismo e estabelecer a herança dos lócus. Estes autores testaram 90 iniciadores aleatórios para RAPD para escolher marcadores para geração parental e progênie 
de truta arco-íris. Dos 90 iniciadores, 25 amplificaram o DNA da truta arco-íris, sendo que o número médio de amplicons por iniciador foi de 5,69, dos quais 2,51 foram polimórficos. Apesar dos cuidados usados com a padronização da reação de PCR, muitos dos iniciadores foram eliminados da análise devido a não reprodutibilidade dos fragmentos ou mesmo pelo aparecimento de bandas não esperadas na progênie. Somente 10 iniciadores polimórficos com amplificações consistentes e com transmissão mendeliana foram usados. Desta forma, os autores são enfáticos em afirmar que o desenvolvimento de uns poucos marcadores confiáveis não compensa o intenso trabalho laboratorial envolvido no uso do RAPD, e que trabalhos genéticos populacionais na ausência de estudos associados de herança produzem resultado questionáveis.

Dos 35 trabalhos publicados com espécies de peixes neotropicais desde 1998 até o presente, 29 usaram espécies da ordem Characiformes, dois da ordem Perciformes e quatro da ordem Siluriformes. Muitos estudos foram feito com a mesma espécie, modificando-se os locais de coleta, sendo que para o gênero Astyanax foram sete trabalhos e para o gênero Brycon oito. Também, foi constatado o mesmo trabalho tendo sido publicado em duas revistas diferentes (LOPERA-BARRERO et al., 2008 ${ }_{\mathrm{a}, \mathrm{b}}$ ). A quantificação do número de lócus usados, do número amostral e do número de fragmentos genotipados não permitiu uma comparação direta entre os trabalhos devido à variação encontrada entre estes índices (Tabela 10).

Em relação aos índices de diferenciação populacional, muitos dos trabalhos não apresentaram tais índices calculados, tendo a comparação sido feita por índices de similaridade entre os indivíduos avaliados. Treze estudos usaram a AMOVA por meio do pacote Arlequin para gerar o índice $\Phi$ de diferenciação populacional. Para as espécies da ordem dos Characiformes a média de $\Phi$ foi 0,15 . Naturalmente, estes valores de $\Phi$ gerados para as diferentes espécies em diferentes bacias hidrográficas, principalmente no que se refere às diferentes estratégias e número amostral, apenas permitem que os resultados sejam interpretados localmente para o estudo em questão, sem que os mesmos possam ser considerados para uma meta análise sobre padrões de diferenciação genética populacional dos peixes neotropicais.

Em conclusão, apesar da facilidade técnica para o uso do RAPD, todas as considerações feitas acima mostram que tal marcador não deve ser usado sozinho para análises genéticas populacionais. Na opção de usá-lo, o RAPD deve estar associado a outro marcado, por exemplo, DNAmt, ou mesmo usá-lo associado ao desenvolvimento de marcadores mais específicos para a espécie em estudo por meio do marcador SCAR (Sequence Characterized Amplified Region).

Os trabalhos publicados com RAPD até o momento devem sim servir de referência para outros trabalhos com as mesmas espécies, mas com a utilização de outros marcadores, como microssatélites, para uma confirmação dos resultados encontrados e recomendações feitas. 


\subsubsection{Microssatélites (Short Tandem Repeats)}

Marcadores baseados em regiões repetidas do genoma para análises genéticas tornou-se realidade após a publicação dos trabalhos de Wyman e White (1980) e Jeffreys et al. (1985a). Inicialmente, os marcadores conhecidos como minissatélites (VNTR - Variable Number of Tandem Repeats) foram usados para questões forenses em humanos e animais (JEFFREYS et al., 1985; BURKE; BRUFORD, 1987).

Logo na década de 1990, os marcadores minissatélites começaram a ser usados em peixes para uma série de questões incluindo discriminação de estoques (CARTER et al., 1991; O'REILLY; WRIGHT, 1995; TAGGART et al., 1995; FERGUSON et al., 1995; TAYLOR, 1995). Problemas associados ao uso dos minissatélites para estudos populacionais foram logo notados, tais como: (i) dificuldades na associação de uma banda a um lócus, (ii) reprodutibilidade e interpretação dos géis; (iii) necessidade do desenvolvimento de sondas específicas para um determinado lócus, na maioria dos casos espécie-específica; (iv) uso de southern blotting; (v) necessidade de DNA em quantidade e de boa qualidade. As dificuldades e as demandas técnicas no uso de minissatélites fizeram com que tal marcador não fosse usado de forma mais abrangente em estudos genéticos populacionais em peixes. Não há registro de trabalhos com marcadores minissatélites com o uso de sondas em peixes neotropicais. Há um trabalho de Wasko e Galleto-Jr. (2003) em que uma abordagem chamada de amplificação direcionada de regiões minissatélites de DNA (Directed Amplification of Minisatellite-region DNA DAMD-PCR) foi utilizada. Nesta metodologia, um único iniciador é usado para amplificar regiões ricas em minissatélites (HEATH et al., 1993), e com isto detectar polimorfismo entre e dentro de espécies. O trabalho em questão foi usado para detectar diferenças entre espécies do gênero Brycon, e em particular para populações da espécie B. lundii.

Com o surgimento dos chamados microssatélites (STR), alguns dos problemas associados ao uso dos minissatélites foram solucionados, aumentando siginificativamente o uso deste marcador em estudos genéticos populacionais. Nas duas últimas décadas, o desenvolvimento de técnicas para geração de lócus STR tem permitido a disponibilização cada vez maior de lócus de diferentes espécies de diferentes táxons (ZANE et al., 2002). Isto pode ser constatado pela criação de revistas científicas específicas para publicação de lócus microssatélites com as sequências de iniciadores, condições de amplificação, níveis de polimorfismo e algumas vezes mostrando a capacidade do lócus de uma espécie gerar amplicons de espécies taxonomicamente relacionadas (amplificação cruzada - RICO et al., 1996), tais como Molecular Ecology Resources (incialmente conhecido como Molecular Ecology Notes) ou mesmo a Conservation Genetics Resources 
que também é devotada a publicar metodologias para conservação da diversidade genética e lócus microssatélites.

Em peixes, o aumento na geração de marcadores STRs espécie-específicos tem sido particularmente significativo juntamente com mamíferos (ZANE et al., 2002), e seu uso em estudos genético populacionais de peixes tem aumentado consideravelmente (DEWOODY; AVISE, 2000; XIAO-GU, 2006). Pode-se afirmar que apesar da intensa discussão acerca do uso de marcadores STRs (CHAMBERS; MACAVOY, 2000), os STRs têm sido o marcador baseado no genoma nuclear mais utilizado em estudos genéticos populacionais (JARNE; LAGODA, 1996).

Em peixes neotropicais de água doce, um aumento significativo de artigos relacionado ao uso dos STRs para estudos populacionais tem sido registrado. Esta constatação pode ser verificada pela quantidade de artigos específicos de geração de lócus microssatélites para diversas espécies. Para uma melhor compreensão da evolução desta abordagem em peixes neotropicais, um resumo dos artigos publicados será apresentado na tabela 10 por ordem cronológica de publicação. 
Tabela 10. Relação de estudos publicados sobre o desenvolvimento de lócus STR.

\begin{tabular}{|c|c|c|c|c|}
\hline Espécie & $\mathbf{N L}$ & $\mathrm{Na}$ & $\mathrm{He}$ & Referência \\
\hline $\begin{array}{c}\text { Amphilophus citrinellum } \\
\text { PER }\end{array}$ & 6 & 11,16 & 0,325 & Noack et al. (2000) \\
\hline $\begin{array}{c}\text { Piaractus mesopotamicus } \\
\text { CHA }\end{array}$ & 8 & 6,50 & 0,532 & Calcagnotto et al. (2001) \\
\hline $\begin{array}{l}\text { Prochilodus sp. } \\
\text { CHA }\end{array}$ & 1 & 11 & - & Hatanaka et al .(2002) \\
\hline $\begin{array}{l}\text { Poecilia reticulate } \\
\text { CYP }\end{array}$ & 8 & 11,30 & 0,728 & Becher et al. (2002) \\
\hline $\begin{array}{c}\text { Astyanax fasciatus } \\
\text { CHA }\end{array}$ & 6 & 20,3 & 0,800 & Strecker (2003) \\
\hline $\begin{array}{l}\text { Arapaima gigas } \\
\text { OST }\end{array}$ & 14 & 4,20 & 0,622 & Farias et al. (2003) \\
\hline $\begin{array}{l}\text { Brycon opalinus } \\
\text { CHA }\end{array}$ & 7 & 19,8 & 0,875 & Barroso et al. (2003) \\
\hline $\begin{array}{c}\text { Nannostomus unifasciatus } \\
\text { CHA }\end{array}$ & 9 & 9,60 & 0,644 & Beheregaray et al. (2004) \\
\hline $\begin{array}{c}\text { Paracheirodon axelrodi } \\
\text { CHA }\end{array}$ & 14 & 9,14 & 0,770 & Beheregaray et al. (2004) \\
\hline $\begin{array}{c}\text { Hemigrammus bleheri } \\
\text { CHA }\end{array}$ & 8 & 10,75 & 0,718 & Beheregaray et al. (2005) \\
\hline $\begin{array}{l}\text { Pimelodella chagresi } \\
\text { SIR }\end{array}$ & 8 & 12,90 & 0,851 & Moeser e Bermingham (2005) \\
\hline $\begin{array}{c}\text { Pseudoplatystoma corruscans } \\
\text { SIR }\end{array}$ & 5 & 11,8 & 0,813 & Revaldaves et al. (2005) \\
\hline $\begin{array}{c}\text { Eigenmannia sp. } 2 \\
\text { GYM }\end{array}$ & 10 & 15,11 & 0,820 & Moysés et al.(2005) \\
\hline $\begin{array}{l}\text { Carnegiella marthae } \\
\text { CHA }\end{array}$ & 7 & 9,71 & 0,572 & Beheregaray et al. (2006) \\
\hline $\begin{array}{l}\text { Prochilodus costatus } \\
\text { CHA }\end{array}$ & 6 & 11,00 & 0,640 & Carvalho-Costa et. al. (2006) \\
\hline $\begin{array}{l}\text { Brycon bilarii } \\
\text { CHA }\end{array}$ & 7 & 5,57 & 0,667 & Sanches \& Galetti (2006) \\
\hline $\begin{array}{c}\text { Procbilodus argenteus } \\
\text { CHA }\end{array}$ & 13 & 10,76 & 0,726 & Barbosa et al. (2006) \\
\hline $\begin{array}{l}\text { Poecilia reticulate } \\
\text { CYP }\end{array}$ & 51 & 4,84 & 0,460 & Shen et al. (2007) \\
\hline $\begin{array}{c}\text { Leporinus macrocephalus } \\
\text { CHA }\end{array}$ & 8 & 10,87 & 0,833 & Morelli et al. (2007) \\
\hline $\begin{array}{l}\text { Prochilodus lineatus } \\
\text { CHA }\end{array}$ & 5 & 12 & 0,778 & Yazbeck e Kalapothakis(2007) \\
\hline $\begin{array}{l}\text { Procbilodus argenteus } \\
\text { CHA }\end{array}$ & 9 & 12,8 & 0,785 & Barbosa et al.(2008) \\
\hline $\begin{array}{l}\text { Poecilia parae } \\
\text { CYP }\end{array}$ & 16 & 17,9 & 0,850 & Nater et al. (2008) \\
\hline $\begin{array}{l}\text { Pimelodus maculatus } \\
\text { SIR }\end{array}$ & 11 & 13,3 & 0,851 & Paiva e Kalapothakis (2008) \\
\hline $\begin{array}{l}\text { Arapaima gigas } \\
\text { OST }\end{array}$ & 8 & 8,00 & 0,723 & Hamoy et al. (2008) \\
\hline $\begin{array}{l}\text { Symphysodon discus } \\
\text { PER }\end{array}$ & 13 & 4,30 & 0,357 & Amado et al. (2008) \\
\hline $\begin{array}{c}\text { Colossoma macropomum } \\
\text { CHA }\end{array}$ & 14 & 11,57 & 0,780 & Santos et al. (2009) \\
\hline
\end{tabular}


Tabela 10. Continuação

\begin{tabular}{|c|c|c|c|c|}
\hline Espécie & NL & $\mathbf{N a}$ & $\overline{\mathrm{He}}$ & Referência \\
\hline $\begin{array}{c}\text { Astronotus crassipinis } \\
\text { PER }\end{array}$ & 13 & 2,76 & 0,404 & Sousa et al. (2009) \\
\hline $\begin{array}{c}\text { Brachyplatystoma vaillantii } \\
\text { SIR }\end{array}$ & 15 & 11,33 & 0,789 & Rodrigues et al. (2009) \\
\hline $\begin{array}{l}\text { Zungaro jabu } \\
\text { SIR }\end{array}$ & 8 & 6,75 & 0,659 & Carrillo-Avila et al. (2009) \\
\hline $\begin{array}{c}\text { Cicbla monoculus } \\
\text { PER }\end{array}$ & 12 & 6,41 & 0,638 & Lima et al. (2010) \\
\hline $\begin{array}{c}\text { Semaprochilodus insignis } \\
\text { CHA }\end{array}$ & 16 & 16,37 & 0,884 & Passos et al. (2010) \\
\hline $\begin{array}{c}\text { Brachyplatystomarousseauxii } \\
\text { SIR }\end{array}$ & 30 & 9,87 & 0.706 & Batista et al. (2010) \\
\hline $\begin{array}{c}\text { Hoplias malabaricus } \\
\text { CHA }\end{array}$ & 14 & 2,16 & 0,360 & Gondim et al. (2010) \\
\hline $\begin{array}{l}\text { Salminus bilarii } \\
\text { CHA }\end{array}$ & 9 & 11,88 & 0,894 & Silva e Hilsdorf (2011) \\
\hline $\begin{array}{l}\text { Prochilodus lineatus } \\
\text { CHA }\end{array}$ & 13 & 9,69 & 0,648 & Rueda et al. (2011) \\
\hline $\begin{array}{l}\text { Leporinus friderici } \\
\text { CHA }\end{array}$ & 8 & 6,83 & 0,676 & Olivatti et al. (2011) \\
\hline $\begin{array}{c}\text { Colossoma macropomum } \\
\text { CHA }\end{array}$ & 13 & 7,07 & 0,763 & Hamoy et al. (2011) \\
\hline $\begin{array}{l}\text { Salminus brasiliensis } \\
\text { CHA }\end{array}$ & 8 & 8,75 & 0,597 & Rueda et al. (2011) \\
\hline $\begin{array}{c}\text { Hypostomus gymnorbynchus } \\
\text { SIR }\end{array}$ & 10 & 3,80 & 0,439 & Telles et al. (2011) \\
\hline $\begin{array}{c}\text { Conorbynchus conirostris } \\
\text { SIR }\end{array}$ & 13 & 10,5 & 0,774 & Carvalho e Beheregaray (2011) \\
\hline $\begin{array}{c}\text { Pseudoplatystoma punctifer } \\
\text { SIR }\end{array}$ & 15 & 7,4 & 0.592 & Saulo-Machado et al. (2011) \\
\hline $\begin{array}{l}\text { Amatitlania siquia } \\
\text { PER }\end{array}$ & 4 & 21,2 & - & Lee-Jenkins et al. (2011) \\
\hline $\begin{array}{c}\text { Phractocephalus hemioliopterus } \\
\text { SIR }\end{array}$ & 9 & 5,00 & 0,660 & Souza et al. (2012) \\
\hline $\begin{array}{l}\text { Pygocentrus nattereri } \\
\text { CHA }\end{array}$ & 11 & 8.2 & 0.571 & Nascimento et al. (2012) \\
\hline $\begin{array}{c}\text { Pterygoplichlbys pardalis } \\
\text { SIR }\end{array}$ & 9 & 6,6 & 0.692 & Pereira et al. (2012) \\
\hline $\begin{array}{c}\text { Astyanax altiparanae } \\
\mathrm{CHA}\end{array}$ & 11 & 7,54 & 0,799 & Zaganini et al. (2012) \\
\hline $\begin{array}{c}\text { Trichomycterus areolatus } \\
\text { SIR }\end{array}$ & 10 & 4,4 & 0,580 & Munõz-Rojaset al. (2012) \\
\hline $\begin{array}{c}\text { Colossoma macropomum } \\
\text { CHA }\end{array}$ & 12 & 8,8 & 0,794 & Hamoy e Santos (2012) \\
\hline $\begin{array}{c}\text { Hoplias microlepis } \\
\text { CHA }\end{array}$ & 14 & 5,22 & 0,56 & Vu et al. (2013) \\
\hline
\end{tabular}


Os estudos genéticos populacionais baseados no polimorfismo dos marcadores microssatélites com peixes de água doce da região neotropical têm crescido à medida que novos lócus espécie-específicos são publicados. Com o objetivo de compreender a evolução destes marcadores em estudos genéticos de população, optou-se em apresentar os trabalhos em ordem cronológica de publicação dentro de cada uma das ordens de classificação taxonômica das espécies.

A primeira ordem a ser abordada é que apresenta o maior número de trabalhos; a ordem dos Characiformes. Barroso et al. (2005), estudaram a espécie Brycon opalinus. (Pirapitinga-do-sul). Esta espécie é endêmica da bacia do Paraíba do Sul, não é uma espécie alvo da pesca ou piscicultura, contudo ocorre em rios e riachos de cabeceiras e é bem adaptada a águas frias de altitude. Desde a década de 1980, é uma das espécies eleitas para os programas de repovoamento da CESP/Paraibuna. O trabalho em questão avaliou a diversidade genética de populações selvagens e o estoque reprodutor da Estação de Piscicultura da CESP/Paraibuna. As populações avaliadas apresentaram de baixa a moderada diferenciação genética. Neste trabalho os resultados foram: (i) Número de lócus usados= 7; (ii) Número médio de alelos por lócus= 11,48; (iii)Número de populações= 8; (iv) Número amostral total= 229; (v) Número amostral médio por população= 32,12; (vi) Heterozigosidade média esperada total=85,6\%; (vii) $\Phi_{S T}=0.0432$.

Pineda-Santiset al. (2006), estudaram a diversidade genética da espécie Piaractus brachypomus (Cachama Blanca ou pirapitinga em português) em indivíduos provenientes do Rio Meta na Colômbia. Segundo os autores, esta é a espécie mais importante para piscicultura de pequenos produtores na Colômbia. O trabalho resumiu-se em avaliar 30 indivíduos originados de reprodutores capturados no rio Meta com lócus desenvolvidos para Piaractus mesopotamicus. Neste trabalho os resultados foram: (i) Número de lócus usados=4; (ii) Número médio de alelos por lócus = 4; (iii) Número de populações=1; (iv) Número amostral total= 30; (v) Número amostral médio por população= 30; (vi) Heterozigosidade média esperada total $=46,8 \%$; (vii) $\Phi_{S T}=$ não calculado.

Hatanakaet al. (2006), avaliaram a diferenciação genética entre populações da espécie Procbilodus argenteus (curimbatá) da bacia do rio São Francisco na região do reservatório de Três Marias. O trabalho objetivou avaliar duas populações em uma região afetada por barramento em três anos de amostragem. Neste trabalho os resultados foram: (i) Número de lócus usados=4; (ii) Número médio de alelos por lócus= 7,45; (iii) Número de populações $=2$; (iv) Número amostral total= 132; (v) Número amostral médio por população= 21,8; (vi) Heterozigosidade média esperada total $=51,3 \%$; (vii) $\mathrm{F}_{S T}=0,008$. 
A espécie Brycon moorei sinuensis é uma espécie comercialmente importante, principalmente na região da bacia do rio Sinú, sendo este o terceiro mais importante rio da vertente do caribe na Colômbia. Atualmente devido à sobre pesca e fragmentação ambiental, a captura desta espécie está reduzida. López (2006), avaliou a variabilidade genética de populações selvagens e de cativeiro, estas últimas usadas em programas de repovoamento, com a amplificação cruzada de lócus microssatélites desenvolvidos para Piaractus mesopotamicus. Os índices de diversidade genética sugerem que as populações apresentam endogamia e baixa diferenciação entre as populações, com indicativos de efeito gargalo em três dos locais avaliados. Neste trabalho os resultados foram: (i) Número de lócus usados= 6; (ii) Número médio de alelos por lócus= 7,83; (iii) Número de populações $=6$ (duas amostragens de populações selvagens e quatro de reprodutores de estações de piscicultura); (iv) Número amostral total= 262; (v) Número amostral médio por população $=43,6$; (vi) Heterozigosidade média esperada total $=68,0 \%$; (vii) $\mathrm{F}_{S T}=0.0427$.

A hipótese da existência de ondas migratórias diferenciadas em um mesmo estoque reprodutivo de curimbatá (Prochilodus lineatus) foi testada em amostragens de populações migratórias (outubro a janeiro) e residente (julho e setembro) na região da cachoeira de Emas no rio Mogi-Guaçu (MORELLI et al., 2007). As comparações dentro das populações residentes e migrantes, como também entre elas, mostraram moderada diferenciação populacional. $\mathrm{O}$ trabalho sugere que outros estudos devam ser realizados, contudo os resultados indicam que possa existir subestruturarão dentro de um mesmo estoque devido às diferentes ondas migratórias durante o período reprodutivo. Neste trabalho os resultados foram: (i) Número de lócus usados= 4; (ii) Número médio de alelos por lócus= 14; (iii) Número de populações $=1$ (duas amostragens no período residente e duas no período migratório); (iv) Número amostral total=100; (v) Número amostral médio por população= 25; (vi) Heterozigosidade média esperada total= 15,74\%; (vii) $\Phi_{S T}=0,072$.

Outro estudo com uma espécie de curimbatá ( $P$. costatus) também na região do reservatório de Três Marias foi realizado por Carvalho-Costa et al. (2008). Neste trabalho, os resultados sugerem que a população na região estudada compõe um único estoque reprodutivo. Neste trabalho os resultados foram: (i) Número de lócus usados= 6; (ii) Número médio de alelos por lócus= 7,6; (iii) Número de populações= 3; (iv) Número amostral total $=57$; (v) Número amostral médio por população= 19; (vi) Heterozigosidade média esperada total= $65,66 \%$; (vii) $\mathrm{F}_{S T}=0,003$.

Matsumoto e Hilsdorf (2009), avaliaram populações da espécie Brycon insiginis (piabanha) coletadas principalmente em rios da região fluminense da bacia do Paraíba do Sul. Esta espécie outrora abundante em todo rio Paraíba do Sul com uma produção pesqueira que chegou a 24 t 
em 1950 (MACHADO; ABREU, 1952), atualmente está extinta no Paraíba do Sul paulista. De acordo com a livro vermelho da fauna brasileira ameaçada de extinção (MACHADO et al., 2008), esta espécie está classificada com seriamente ameaçada de extinção. No trabalho genético populacional foi verificado que as populações estudadas apresentam diferentes níveis de diferenciação genética, e que uma das populações mais isolada pode ser considerada um reservatório genético da espécie. Este trabalho enfatizou a importância de se conhecer as diferenças genéticas de populações ainda existentes para planejar de forma correta os programas de conservação da espécie, principalmente aqueles que envolvem repovoamento. Neste trabalho os resultados foram: (i) Número de lócus usados= 5; (ii) Número médio de alelos por lócus= 7,45; (iii) Número de populações= 6; (iv) Número amostral total= 208; (v) Número amostral médio por população $=34,6$; (vi) Heterozigosidade média esperada total $=78,0 \%$; (vii) $\Phi_{S T}=$ 0,07 .

Outro trabalho sobre estrutura genética populacional com a espécie Piaractus mesopotamicus da região do Pantanal mato-grossense e da bacia do Alto Paraná foi desta fez conduzido com o uso de marcadores microssatélites (CALCAGNOTTO; DESALLE, 2009). Este trabalho também observou baixos valores de diferenciação populacional em populações desta espécie na comparação entre rios da região do Pantanal, sendo que valores moderados foram observados quando comparados locais de coleta da Bacia do Alto Paraná (Paranapanema) com outros da Bacia do Pantanal. O trabalho discute as implicações destes achados para o manejo deste importante recurso pesqueiro. Neste trabalho os resultados foram: (i) Número de lócus usados= 8; (ii) Número médio de alelos por lócus= 8,5; (iii) Número de populações=6; (iv) Número amostral total= 120; (v) Número amostral médio por população= 20; (vi) Heterozigosidade média esperada total $=59,1 \%$; (vii) $\Phi_{S T}=0.0145$.

Lopera-Barrero et al. (2010), avaliaram populações selvagens e reprodutores de programas de repovoamento do pacu (P. mesopotamicus) coletados em escadas de peixes em duas barragens no rio Paranapanema (Canoa I e II). Os achados deste trabalho mostraram que tanto o estoque de reprodutores como os selvagens que passam pelas escadas das barragens apresentam níveis de variabilidade genética satisfatória, apesar do número de alelos ser relativamente pequeno, os autores sugerem que a pouca diferença genética entre a população selvagem e a de cativeiro pode ser um indicativo de que as selvagens são populações estabelecidas com os programas de repovoamento. Os autores alertam para os efeitos das condições ambientais a montante das barragens e o não retorno de populações migrantes de montante para jusante para o estabelecimento de populações a montante das barragens. Neste trabalho os resultados foram: (i) Número de lócus usados=4; (ii) Número médio de alelos por lócus=4; (iii) Número de 
populações $=3$; (iv) Número amostral total= 71 (apenas incluindo as populações selvagens e os reprodutores); (v) Número amostral médio por população=14,2; (vi) Heterozigosidade média esperada total $=71,1 \%$; (vii) $\mathrm{F}_{S T}=0,023$ (sem a progênie).

A espécie Leporinus elongates (RAMOS et al., 2012) foi avaliada nas barragens de Canoa I e II no rio Paranapanema. Neste estudo foi possível verificar que os grupos amostrados nas escadas de peixes dos dois reservatórios em três períodos reprodutivos são pertencentes a uma única unidade reprodutiva sem diferenciação genética significativa entre os dois reservatórios. As conclusões aqui observadas corroboram com aquelas sugeridas no trabalho anteriormente descrito para P. mesopotamicus. Neste trabalho os resultados foram: (i) Número de lócus usados= 5; (ii) Número médio de alelos por lócus= 14,9; (iii) Número de populações= 10 (amostragens em período diferentes em anos diferentes); (iv) Número amostral total= 258; (v) Número amostral médio por população= 23 (Canoas I) e 30 (Canoas II); (vi) Heterozigosidade média esperada total $=88,0 \%$; (vii) $\Phi_{S T}=0,014$.

Sanches et al. (2012), investigaram a diferenciação populacional entre três pontos a jusante do reservatório de Três Marias no Rio São Francisco de duas espécies desta região; Brycon orthotaenia (matrinhã) e Prochilodus argenteus (curimbatá). A espécie B. orthotaenia pode ser diferenciada em duas populações distintas, enquanto as populações da espécie P. argenteus constituem uma única população. Neste trabalho, os resultados para a espécie B. orthotaenia foram: (i) Número de lócus usados= 5; (ii) Número médio de alelos por lócus= 6,39; (iii) Número de populações= 3; (iv) Número amostral total= 44; (v) Número amostral médio por população= 14,3; (vi) Heterozigosidade média esperada total $=70,8 \%$; (vii) $\mathrm{F}_{S T}=0,069$. Para a espécie Prochilodus argenteus foram:(i) Número de lócus usados=10; (ii) Número médio de alelos por lócus= 8,33; (iii) Número de populações= 2; (iv) Número amostral total=46; (v) Número amostral médio por população= 23; (vi) Heterozigosidade média esperada total $=70,0 \%$; (vii) $\mathrm{F}_{S T}=0,002$.

Sanches e Galetti-Jr (2012), avaliaram a estrutura genética populacional da espécie Brycon bilarii na bacia do Rio Miranda no Pantanal. Este estudo mostrou que as populações desta espécie na região estudada apresenta diferenciação genética durante o período reprodutivo quando comparada com populações locais. Os autores sugeriram que a diferenciação genética durante o período reprodutivo pode ser explicada por um comportamento que promove a manutenção da integridade genética das diferentes populações durante o processo migratório. Este fenômeno é importante para se entender comportamentos migratórios e manutenção da variabilidade dos recursos genéticos de peixes de água doce neotropicais. Neste trabalho os resultados foram: (i) Número de lócus usados= 7; (ii) Número médio de alelos por lócus= 5,75; (iii) Número de 
populações= 4; (iv) Número amostral total=128; (v) Número amostral médio por população= 32; (vi) Heterozigosidade média esperada total $=60,2 \%$; (vii) $\mathrm{F}_{S T}=0,0184$.

Outra abordagem genética populacional mais ampla com a espécie B. hillari com amostragens em diferentes sub-bacias foi realizada por Okazaki (2009). Neste estudo foi observado que mesmo que haja algum nível de diferenciação genética de populações residentes nas sub-bacias que compõem a drenagem do Pantanal mato-grossense, quando se considera a bacia como um todo, as populações exibem de baixa diferenciação a panmixia. Este padrão de não diferenciação foi também observado em dois outros trabalhos com pacu com DNAmt (IERVOLINO et al., 2010) e microssatélites (CALCAGNOTTO; DESALLE, 2009) apresentados anteriormente e parecem estar relacionados ao fenômeno de pulso de inundações presente anualmente na região. Neste trabalho os resultados foram: (i) Número de lócus usados= 6; (ii) Número médio de alelos por lócus= 8,79; (iii) Número de populações= 4; (iv) Número amostral total= 157; (v) Número amostral médio por população= 39,25; (vi) Heterozigosidade média esperada total $=76,30 \%$; $(\mathbf{v i i}) \Phi_{S T}=0,0104$ e $D_{E S T}=0,0103$.

A fragmentação do meio ambiente aquático por diversos fatores antrópicos tem sido uma constante em rios da região neotropical. A construção de barragens é um destes fatores que cria barreiras à migração de peixes muitas vezes impedindo seu processo reprodutivo. Silva (2013), utilizou como modelo para testar a hipótese de como a fragmentação de rios pode levar a diferenciação genética entre populações a espécie Salminus hillari, conhecida como tabarana. Esta espécie é bem conhecida por sua ocorrência em grande parte da bacia do Alto Paraná. Como é uma espécie sem interesse comercial, não há registros de sua abundância pretérita. Neste trabalho, quatro populações em diferentes rios da bacia do Alto Paraná foram avaliadas, sendo duas destas populações presentes em um trecho de rio separado por uma barragem. As análises mostraram moderada diferenciação genética entre as populações que podem ser resultado natural do comportamento reprodutivo da espécie, já que a mesma é considerada de curta migração, ou mesmo causa direta da fragmentação ambiental. Neste trabalho os resultados foram: (i) Número de lócus usados= 5; (ii) Número médio de alelos por lócus= 13,8; (iii) Número de populações= 4; (iv) Número amostral total= 151; (v) Número amostral médio por população= 37,7; (vi) Heterozigosidade média esperada total $=90,23 \%$; (vii) $\Phi_{S T}=0,0192 \mathrm{e}_{E S T}=0,122$

A ordem dos Siluriformes juntamente com os Characiformes é a ordem com mais espécies de ocorrência na região neotropical. Apesar da importância dos siluriformes tanto para diversidade ictíica como para pesca e aquicultura, poucos trabalhos têm sido publicados sobre a diversidade intra e interpopuacional com este grupo de peixes. 
Pereira et al. (2009), estudaram a estrutura genética de populações da espécie Pseudoplatystoma corruscans também conhecida como pintado. Esta espécie é um bagre migrador de longas distâncias e pode ser encontrado nas bacias dos rios Amazonas, do Paraguai, do Paraná, do São Francisco e do rio Orinoco na Venezuela e Colômbia. Esta espécie é de grande importância para pesca e aquicultura no Brasil (2.486,5 $\mathrm{t}$ - aquicultura e 2.043,4 $\mathrm{t}$ - pesca - MPA, 2010). Os autores avaliaram populações selvagens coletadas em rios da bacia do rio Paraguai e do rio Paraná e encontraram valores moderados de diferenciação genética entre as populações estudadas. Outra sugestão feita a partir dos resultados encontrados é a possibilidade do fenômeno conhecido como homing que é o retorno dos reprodutores após a migração reprodutiva para seu local de origem ao invés de migrarem para outros locais para o período de alimentação. Os resultados apresentados têm implicações importantes tanto no que concernem estratégias de manejo para as populações selvagens como para a obtenção de material genético para programas de melhoramento genético da espécie para piscicultura. Neste trabalho os resultados foram: (i) Número de lócus usados= 7; (ii) Número médio de alelos por lócus=8,33; (iii) Número de populações= 6; (iv) Número amostral total= 233; (v) Número amostral médio por população= 38,8; (vi) Heterozigosidade média esperada total $=70,86 \%$; (vii) $\Phi_{S T}=0,10 \mathrm{e} \mathrm{R}_{S T}=0,04$.

A espécie de bagre Psendoplatystoma reticulatum conhecido como cachara foi também objeto de estudo genético populacional de exemplares coletados na bacia do Alto rio Paraguai no Pantanal Mato-grossense (ABREU et al., 2009). Esta é outra espécie de bagre de interesse econômico no Brasil (1.038,10 t - pesca). A comparação populacional foi feita entre dois pontos coletados na referida bacia hidrográfica. Níveis de altos de variabilidade genética e diferenciação populacional foram encontrados o que sugere que padrões de estruturação genética pode ser uma característica deste grupo de peixes. Neste trabalho os resultados foram: (i) Número de lócus usados $=7$; (ii) Número médio de alelos por lócus $=5,57$; (iii) Número de populações $=2$; (iv) Número amostral total $=52$; (v) Número amostral médio por população= 26; (vi) Heterozigosidade média esperada total $=48,83 \%$; (vii) $\Phi_{S T}=0,229$ e $\mathrm{R}_{S T}=0,106$.

Entre as espécies de bagres de ocorrência em bacias hidrográficas brasileiras, encontra-se a espécie Trichogenes longipinnis, conhecida popularmente como cambeva. Este bagre de pequeno porte habita riachos da região de Mata Atlântica, sendo endêmico destas regiões e está classificado pelo Livro Vermelho da Fauna Brasileira Ameaçada de Extinção com o status de vulnerável devido a constante fragmentação ambiental de seus locais de ocorrência (MACHADO et al., 2008). Zamudio et al. (2009), avaliaram populações desta espécie endêmica de bagre em regiões de Mata Atlântica na região litorânea entre os estados de São Paulo e Rio de Janeiro que apresentaram substancial estruturação genética entre as populações avaliadas. $O$ trabalho discute 
a importância do entendimento da diferenciação genética em populações de espécies de distribuição reduzida para o planejamento de ações de conservação. Neste trabalho os resultados foram: (i) Número de lócus usados= 7; (ii) Número médio de alelos por lócus $=3,25$; (iii) Número de populações= 5; (iv) Número amostral total= 117; (v) Número amostral médio por população $=23,4$; (vi) Heterozigosidade média esperada total= 10,10\%; (vii) $\mathrm{F}_{S T}=0,417$.

Uma importante bacia hidrográfica no sul do Brasil, a bacia do Rio Uruguai, tem sido alvo de barramentos para geração de energia elétrica ao longo dos últimos anos. Ribolli et al. (2012), avaliaram os possíveis efeitos destes barramentos sobre as populações de uma espécie migradora de bagre, o mandi-pintado (Pimelodus maculatus). Neste trabalho, os autores propuseram que as populações de mandi avaliadas ao longo dos rios Uruguai e Pelotas a montante e a jusante das diversas barragens não estão estruturadas em populações geneticamente distintas. Apesar dos resultados das análises pelos pacotes Structure e SAMOVA não indicarem diferenciação populacional, os índice global de fixação $\Phi_{S T}$ e o valor médio alto de $\mathrm{D}_{E S T}(>0,15)$ sugerem que a hipótese de ausência de estruturação genética deve ser rejeitada. Mesmo levando em consideração o hábito migrador da espécie, não se pode afirmar se tais diferenciações são causas diretas da construção das barragens. Neste trabalho os resultados foram: (i) Número de lócus usados= 8; (ii) Número médio de alelos por lócus= 15,81; (iii) Número de populações $=4$ (coletadas a partir de 11 subpopulações); (iv) Número amostral total= 210; (v) Número amostral médio por população= 52,5; (vi) Heterozigosidade média esperada total $=81,14 \%$; (vii) $\Phi_{S T}=$ $0,0229, \mathrm{D}_{E S T}=0.255$.

Carvalho et al. (2012), avaliaram amostras de Pseudoplatystoma corruscans de quatro locais, agrupando-as em duas populações: uma na bacia do rio São Francisco e uma na bacia do Rio Paraguai/Paraná. Os autores observaram que os indivíduos se agruparam em duas populações marcadamente distintas e que a magnitude da diferenciação pode classificar as populações das duas regiões como duas ESU (Evolutionarily Significant Units). Os resultados deste trabalho corroboram o estudo relatado anteriormente com a mesma espécie que também mostrou níveis de diferenciação populacional. As implicações destes achados acentuam a atenção que deve ser dada aos programas de manejo conservacionista da espécie, bem como o potencial do uso de recursos genéticos distintos em programas de melhoramento genético da espécie. Neste trabalho os resultados foram: (i) Número de lócus usados= 8; (ii) Número médio de alelos por lócus= 6,6; (iii) Número de populações= 2; (iv) Número amostral total= 47; (v) Número amostral médio por população= 23,5; (vi) Heterozigosidade média esperada total= não informado; (vii) $\mathrm{F}_{S T}=0,18, \mathrm{D}_{E S T}=0.24$ (material suplementar ao artigo). 
Estudos com espécies da ordem dos Cyprinodontiformes têm sido realizados com abordagens evolutivas principalmente na região da América Central. Turner et al. (2008), avaliaram morfotipos possivelmente da espécie Cyprinodon variegatus em San Salvador. Os autores observaram significativa diferença genética entre populações simpátricas dos morfotipos chamados de normal e bozo e o chamado de bulldog, e que provavelmente isto esteja ocorrendo devido ao isolamento reprodutivo e interações presa-predador via um processo chamado pelos autores de especiação ecológica. Se os representantes dos morfotipos são populações da mesma espécie ou um complexo de espécies não está claro. De qualquer forma, o estudo de uma espécie de pequeno porte, mas que exerce um importante papel no ecossistema no controle de mosquitos (AVILA et al., 1992) mostra que a avaliação dos recursos genéticos mesmo de espécie de peixes sem uma importância econômica direta, como as espécies de peixes para produção de alimento, está também relacionada indiretamente a saúde e bem estar do homem. Neste trabalho os resultados foram: (i) Número de lócus usados= 8; (ii) Número médio de alelos por lócus= 4,87 ; (iii) Número de populações= 9 (cinco localidades); (iv) Número amostral total= 238; (v) Número amostral médio por população $=47,6$; (vi) Heterozigosidade média esperada total= $28,01 \%$; (vii) $\mathrm{F}_{S T}=0,177$.

Dois trabalhos sobre estrutura e erosão da variabilidade genética foram feitos por dois grupos independentes com Poecilia reticulata (lebiste/guppy) na ilha de Trinidad e Tobago. Suk e Neff (2009), sugeriram que as populações de lebistes avaliadas apresentam um complexo padrão de fluxo gênico e diferenciação genética entre as populações das diferentes drenagens e que sugere mais de dois eventos de colonização a partir de populações isoladas. Neste trabalho os resultados foram: (i) Número de lócus usados= 7; (ii) Número médio de alelos por lócus=7; (iii) Número de populações= 3 (quinze localidades); (iv) Número amostral total= 373; (v) Número amostral médio por população= 124,3 $(24,8)$; (vi) Heterozigosidade média esperada total=55,4\%; (vii) $F_{S T}=0,28 ; R_{S T}=0,447, G_{S T}^{\prime}=0,941$. O segundo trabalho foi realizado especificamente com populações em uma das áreas avaliadas no estudo anterior. Barson et al. (2009), avaliaram populações de duas regiões de uma área de cabeceira de rio. Níveis altos de diferenciação genética também foram encontrados, sugerindo que a drenagem em estudo pode ser considerada um modelo de metapopulação no padrão doador-receptor que recebe imigrantes de rios mais a montante da drenagem. Neste trabalho os resultados foram: (i) Número de lócus usados= 7; (ii) Número médio de alelos por lócus $=6,18$; (iii) Número de populações $=12$; (iv) Número amostral total $=857$; (v) Número amostral médio por população= 71,41; (vi) Heterozigosidade média esperada total $=43,7 \%$; (vii) $\mathrm{F}_{S T}=0,469$. 
Outro trabalho com um representante da ordem dos Cyprinodontiformes foi realizado em Belize com a espécie Xiphophorus helleri, espécie conhecida como espada é muito utilizada por aquarofilistas. Os resultados do estudo sugerem que populações isoladas apresentam potencial para adaptações locais divergindo de outras populações. Por outro lado, na ausência de obstáculos, as populações estão interconectadas cujas composições genéticas variam com o tempo. Neste trabalho os resultados foram: (i) Número de lócus usados=9; (ii) Número médio de alelos por lócus= 10,6; (iii) Número de populações= 20; (iv) Número amostral total= 542; (v) Número amostral médio por população= 27.1; (vi) Heterozigosidade média esperada total= $76,0 \%$; (vii) $\mathrm{F}_{S T}=0.39$ entre populações separadas por um obstáculo físico e $\mathrm{F}_{S T}=0,07$ entre populações a jusante do obstáculo. Média dos dois índices $\mathrm{F}_{S T}=0,23$.

Vanhaecke et al. (2012), avaliaram a espécie Galaxias maculatus da ordem dos Osmeriformes presente em varias regiões do hemisfério sul em países como Austrália, Nova Zelândia, bem como sul do Chile e Argentina. Apesar de não ser uma espécie estritamente neotropical, em razão de sua ocorrência na América do Sul e ser o referido trabalho o primeiro a estudar os efeitos dos escapes de salmão sobre populações de uma espécie nativa do Chile, incluímos o estudo genético populacional desta espécie juntamente com as espécies neotropicais. Galaxias maculatus está presente em riachos e lagos próximo ao oceano, realizam migrações reprodutivas em direção dos estuários e são na sua maioria semelparos, isto é se reproduzem uma vez na vida e morrem. O trabalho em questão objetivou avaliar as diferenças populacionais e os efeitos dos escapes de salmão dos cultivos comerciais sobre as populações de Galaxias maculatus. Os resultados genéticos não mostraram evidências que as populações de salmões e trutas provenientes de escape estejam reduzindo a diversidade genética e o número efetivo populacional das populações selvagens de Galaxias maculatus. Neste trabalho os resultados foram: (i) Número de lócus usados=10; (ii) Número médio de alelos por lócus= ?; (iii) Número de populações=9; (iv) Número amostral total= 335; (v) Número amostral médio por população= 37,2; (vi) Heterozigosidade média esperada total=?; (vii) $\mathrm{F}_{S T}=0.0023 ; \mathrm{D}_{E S T}=0,026$.

Como representante da ordem dos Osteoglossiformes, populações de pirarucu (Arapaima gigas) ao longo da calha do Rio amazonas foram estudadas com lócus microssatélites (HRBEK et al., 2007). Este trabalho encontrou um efeito de isolamento por distância e realizou uma abordagem de autocorrelação espacial sugerindo que o fluxo gênico entre as populações e restrito a distâncias maiores que $2.500 \mathrm{~km}$. Os autores recomendam que os programas de conservação e manejo sejam baseados no modelo de metapopulação no padrão doador-receptor com a criação de áreas de reserva de várzea na bacia Amazônica superior, central e inferior. Neste trabalho os resultados foram: (i) Número de lócus usados=14; (ii) Número médio de alelos por lócus= ?; 
(iii) Número de populações= 7; (iv) Número amostral total=126; (v) Número amostral médio por população=18; (vi) Heterozigosidade média esperada total= não informado; (vii) $\mathrm{F}_{S T}=$ não informado.

\subsubsection{Discussão sobre STR}

A utilização dos marcadores STR em estudos genéticos populacionais em peixes de água doce tem sido uma tendência desde o fim dos anos 1990. Esta afirmação pode ser constatada por trabalhos sobre genético populacional com o uso de STRs publicados principalmente com peixes de ocorrência no hemisfério norte (O'CONNELL; WRIGHT, 1997). No caso de peixes de água doce neotropicais, a dificuldade de estudos baseados no polimorfismo de STR residia na disponibilidade de lócus caracterizados para a rica ictiofauna presente na região neotropical. A revisão detalhada das publicações sobre caracterização de lócus mostrou que ao longo dos anos 2000, a quantidade de publicações específicas para caracterização de lócus espécies-específicos cresceu de forma expressiva (Figura 14).

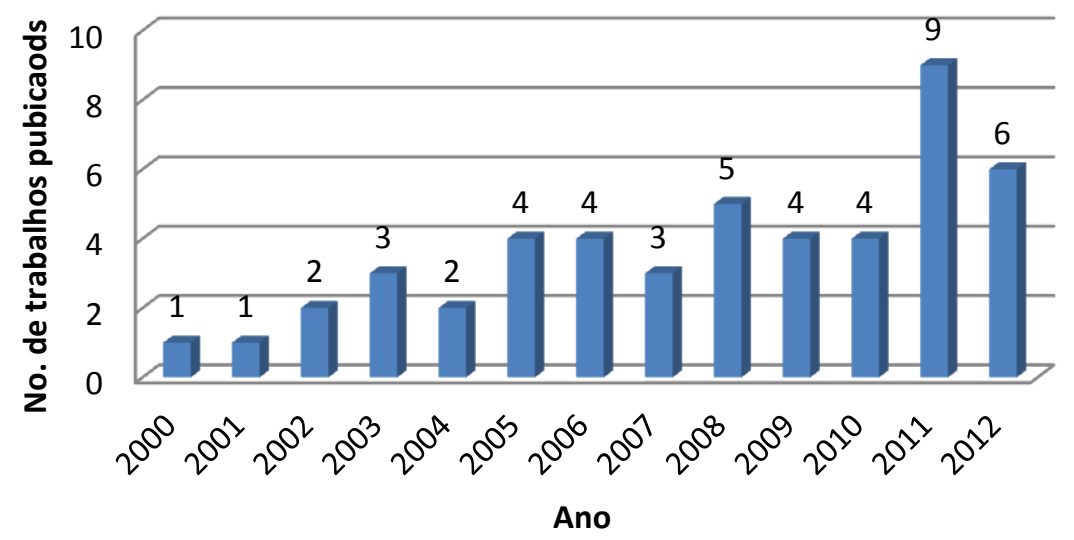

Figura 14. Produção de trabalhos sobre o desenvolvimento de lócus STR de espécies de peixes de água doce neotropicais.

Em uma análise detalhada das metodologias usadas para o isolamento e caracterização dos lócus, se observou uma mudança das estratégias usadas ao longo dos anos. O uso de técnicas de digestão por enzimas de restrição, seguida de clonagem em vetor, transformação em bactérias e finalmente a triagem de fragmentos positivos com STR com sondas radioativas [g-32P]-ATP com sequências de STR específicas, como por exemplo, (GT), (ATC) ou (ATCG) era a técnica 
mais comumente usada no isolamento de lócus STRs. Esta metodologia é laboriosa, envolve marcação radioativa e limita a caracterização de lócus devido à necessidade do uso de sondas diferentes a cada processo. Em outro método que também envolvia a digestão com enzimas de restrição; os fragmentos de DNA enriquecidos com STR (EDWARDS et al., 1996;FISCHER; BACHMANN, 1998; HAMILTON et al., 1999) eram clonados em vetores específicos para transformação em células bacterinas. Clones positivos eram então detectados por marcação quimioluminescente. Esta técnica apresentou um avanço no que concerne o uso de marcação radioativa, pois o uso de sondas quimioluminescentes permitiu aos laboratórios sem autorização para uso de radioatividade gerar com mais facilidade lócus STRs espécie-específicos.

A mesma técnica o isolamento de STRs, teve um avanço com o uso de adaptadores ligados aos fragmentos gerados por uma enzima de restrição (RsaI). Nesta técnica os fragmentos são amplificados por PCR e a regiões com dos fragmentos contendo repetições STR são hibridizadas com sondas ligadas à biotina. Os fragmentos enriquecidos são recuperados por microesferas magnéticas ligadas à estreptavidina. Com isto, os fragmentos contendo repetições STR são então amplificados e clonados para caracterização. Outra técnica que também se tornou popular devido sua simplicidade metodológica foi a chamada RAPD-PIMA (Polymerase Chain Reaction Isolation of Microsatellite Arrays) (LUNT et al., 1999). Esta metodologia baseia-se na geração de fragmentos por RAPD seguida de clonagem de fragmentos previamente selecionados e sequenciamento.

Atualmente, com o maior acesso ao uso de tecnologias de sequenciamento de próxima geração (NGS- Next Geneartion Sequencing), um grande salto tem sido dado na geração de lócus STR em maior quantidade, qualidade e rapidez (ABDELKRIM et al., 2009; PERRY; ROWE, 2010; HOFFMAN; NICHOLS, 2011; ZALAPA et al., 2012). Por exemplo, uma única corrida da plataforma de sequenciamento do equipamento Roche's GS-FLX (454 Life Sciences, Branford, CT, USA) é capaz de gerar ao redor de $400 \mathrm{Mb}$ de dados brutos de sequência, com leituras individuais de até $500 \mathrm{pb}$ o que aumenta consideravelmente as chances de que estas sequências contenham STR (HOFFMAN; NICHOLS, 2011). Esta abordagem foi utilizada no desenvolvimento de lócus para espécie Conorbynchus conirostris (CARVALHO; BEHEREGARAY, 2011).

O crescimento na geração de lócus microssatélites com 49 trabalhos publicados de 2000 a 2013, não produziu o crescimento semelhante nos estudos de genética populacional de espécies de água doce neotropicais com STRs. No presente levantamento de trabalhos publicados em revistas indexadas sobre o tema, um total de 23 trabalhos publicados foi encontrado. Da ordem dos Characiformes, 14 trabalhos foram encontrados, com estudos populacionais de 13 espécies 
(5 do gênero Brycon; 4 do gênero Prochilodus; 2 do gênero Piaractus, 1 do gênero Leporinus e 1 do gênero Salminus). Da ordem dos Siluriformes, cinco foram os trabalhos publicados (3 do gênero Pseudoplatystoma; 1 do gênero Trichogenes e 1 do gênero Pimelodus). Da ordem dos Cyprinodontiformes foram quatro trabalhos publicados (2 do gênero Poecilia; 1 do gênero Cyprinodon e 1 do gênero Xiphophorus). Apenas um trabalho da ordem dos Osmeriformes de uma espécie (gênero Galaxias) de ocorrência na América do Sul, mas não neotropical e 1 trabalho da ordem dos Osteoglossiformes, o pirarucu (único de seu gênero Arapaimas).

Os resultados médios por ordem dos parâmetros avaliados nos trabalhos discutidos napresente revisão pode ser observado na tabela a seguir:

Tabela 11. Valores de parâmetros utilizados nos estudos genéticos populacionais de peixes de água doce neotropical.

\begin{tabular}{cccccccc}
\hline Ordens & NL & NML & NP & NAT & NAMP & He & $\mathbf{F}_{\text {ST }}$ \\
\hline Characiformes & $5,7(1,6)$ & $8,94(3,8)$ & $4,2(3,4)$ & $132,8(75,2)$ & $26,1(8.4)$ & $0,67(0.2)$ & $0,029(0,02)$ \\
Siluriformes & $7,4(0,5)$ & $7,9(4,2)$ & $3,8(1,6)$ & $131,8(77.6)$ & $32,8(11,3)$ & $0,52(0,3)$ & $0,189(0,13)$ \\
Cyprinodontiformes & $7,7(0,8)$ & $7,1(2.1)$ & $8,0(3.7)$ & $502,5(231.2)$ & $67,6(36.3)$ & $0,50(0,2)$ & $0,308(0,12)$ \\
Média geral & $\mathbf{6 , 9}$ & 8,0 & 5,3 & 255,7 & 42,2 & $\mathbf{0 , 5 6}$ & 0,175 \\
\hline
\end{tabular}

NL: Número de lócus; NML: Número médio de alelos por lócus; NP: Número de populações; NAT: Número amostral total; NAMP: Número amostral médio por população; He: Heterozigosidade média esperada total; $\mathbf{F}_{\boldsymbol{S} T} \mathbf{i}$ índice de fixação de diferenciação populacional. Número entre parênteses indicam desvio padrão.

A comparação dos níveis de variabilidade genética entre espécies das três ordens levando em consideração os valores relativos ao número médio de alelo por lócus e a heterozigosidade média esperada total mostram valores moderados de diversidade genética das espécies avaliadas dentro de cada ordem (em negrito na tabela). Apesar do pouco número de artigos para sugerir um padrão de diferenciação genética entre populações dentro de dada ordem, um achado interessante foi o valor médio alto do índice de fixação $\mathrm{F}_{S T}$ de acordo com os valores propostos por Wright (1978) - ver página 55. No caso dos Characiformes, o valor médio obtido é de baixa diferenciação. Já os valores para espécies da ordem dos Siluriformes e Cyprinodontiformes os valores de diferenciação genética são altos. Estes valores altos de estruturação são particularmente relevantes para as espécies de bagres que são de grande interesse para pesca e aquicultura. Naturalmente, tais valores são dependentes de fatores como a abrangência da área de coleta, número amostral usado, e das características de cada espécie, como hábitos migratórios, tipo de reprodução e regime hidrológico nos habitats nos quais vivem. 
O clima e a história geológica dos ecossistemas de águas continentais situados na região neotropical possibilitaram uma diversificação de espécies de peixes de grande magnitude. De certa forma, as espécies de ocorrência em águas neotropicais podem estar interconectadas ou não em diferentes níveis o que leva tais espécies a estabelecer populações locais que são mais ou menos diferenciadas umas das outras por processos de adaptação. A diminuição ou ausência de fluxo gênico possibilita às populações isoladas acumular mutações de novo que seguido de processos de seleção tentam superar os efeitos da deriva genética. Estudos comparativos sobre os níveis de diferenciação populacional entre peixes de água doce de regiões temperadas e peixes da região neotropical pode indicar como a história de ocupação dos ecossistemas de cada região influenciou na diversificação populacional.

Algumas questões importantes devem ser levantadas sobre os trabalhos aqui avaliados. A grande maioria dos cálculos dos índices de diferenciação genética foi baseada no conceito estabelecido por Wright (1978) com análises in silico por diversos pacotes computacionais que promovem um ajuste do tamanho amostral usado com o numero de populações usadas (WEIR; CIOKERMAM, 1984). Como discutido nas anteriormente, os índices de $\mathrm{F}_{S T}$ podem ser influenciados pelos altos níveis de diversidade gerados pelos STR. Se utilizarmos o método proposto por Hedrick (2005) $\left[\mathrm{F}_{\text {STajust. }}=\mathrm{F}_{\mathrm{ST} \cdot} \cdot\left(\mathrm{k}-1+\mathrm{H}_{\mathrm{e}}\right) /(\mathrm{k}-1) \cdot\left(1-\mathrm{H}_{\mathrm{e}}\right)\right]$, o qual promove um ajuste da média da heterozigosidade esperada sob o equilíbrio de Hardy-Weinberg e o número de populações para gerar um $\mathrm{F}_{S T}$ ajustado podemos obter valores mais elevados de diferenciação genética, para os estudos com peixes neotropicais cujos índices médios estão apresentados na tabela 12.

Os valores ajustados do $\mathrm{F}_{S T}$ para os níveis $\mathrm{He}$ e número de populações pode ser observado na tabela 12. Estes novos valores elevam os índices de diferenciação genética para as ordens de peixes neotropicais estudados. Conclui-se que trabalhos futuros devem atentar para os valores gerados de diferenciação levando em consideração o planejamento amostral, número de populações e nível de variabilidade apresentado pelos lócus STRs escolhidos.

Tabela 12. Valores de diferenciação populacional ajustada de acordo com Hedrick (2005).

\begin{tabular}{ccccc}
\hline Ordens & NP & $\mathbf{H e}$ & $\mathbf{F}_{\text {ST }}$ & $\mathbf{F}_{\text {STajustado }}$ \\
\hline Characiformes & $4,2(3,4)$ & $0,67(0.2)$ & $0,029(0,02)$ & $0,106(0,05-015)$ \\
Moderada \\
Siluriformes & $3,8(1,6)$ & $0,52(0,3)$ & $0,189(0,13)$ & $\begin{array}{c}0,466(>0,25) \\
\text { Extensa }\end{array}$ \\
Cyprinodontiformes & $8,0(3.7)$ & $0,50(0,2)$ & $0,308(0,12)$ & $\begin{array}{c}0,66(>0,25) \\
\text { Extensa }\end{array}$ \\
\hline
\end{tabular}

NP: Número de populações; He: Heterozigosidade média esperada total; $\mathbf{F}_{\boldsymbol{S T}}$ : índice de fixação de diferenciação populacional; $\mathrm{F}_{\text {STajustado }}$ de acordo com Hedrick (2005). 
Outra questão que deve ser levada em consideração nos trabalhos de genética populacional com o uso de STR está relacionada ao número amostral usada por população e o número de alelos necessários por lócus para detectar diferenças entre populações que compartilham os mesmos alelos, mas com frequências distintas. Ferguson e Danzmann (1998), simularam testes in silico para verificar os efeitos do número de alelos e o tamanho amostral necessário para (i) detectar diferenças entre duas populações que não diferem em frequências alélicas (erro tipo I) e (ii) não detectar diferenças entre duas populações que realmente diferem em frequências alélicas (erro tipo II). As simulações feitas com as frequências alélicas em equilíbrio de Hardy-Weinberg e considerando uma distribuição normal da população mostraram que nem o tamanho amostral nem o número de alelos afetam a probabilidade de ocorrer o erro tipo I, isto é, a hipervariabilidade dos STRs não aumenta a probabilidade de detectar diferenças entre populações quando elas não existem. Contudo, quando populações que diferem em frequências alélicas são usadas na simulação pode ser observado que o baixo número amostral aumenta a probabilidade de ocorrer o erro tipo II, isto é, não detectar diferenças quando elas existem.

Os autores sugerem que aumentar o tamanho amostral em populações com baixas frequências alélicas é necessário para detectar diferenças em frequências alélicas entre populações, e concluem que lócus com baixo número de alelos não é um limitante para detectar diferenças populacionais. O trabalho sugere que o tamanho amostral de no mínimo 50 indivíduos por população se faz necessário para que a probabilidade de ocorrer o erro tipo II seja significativamente reduzida. O interessante destes resultados é a sugestão de se usar com mais frequências lócus tri e tetra nucleotídicos em análises populacionais.

Por outro lado, Hale et al. (2012), apresentaram resultados com grupos taxonômicos distintos procurando responder quantos indivíduos são necessários para detectar todos alelos presentes em uma população. Os autores argumentam que para obter frequências precisas para gerar estimativas de diversidade não é necessário detectar todos os alelos, já que alelos raros (novas mutações) não são informativos para estimar diversidade intra e interpopulacional. Sendo assim, concluem que a variabilidade em frequência alélica e heterozigosidade esperada diminuem com o aumento do tamanho amostral, porém, esta diminuição é mínima em tamanhos amostrais acima de 25 a 30 indivíduos. Para população cuja amostragem seja inevitavelmente reduzida é sugerido que para uma melhor precisão dos valores de He, o número de lócus utilizados na análise seja aumentado.

Os dados da tabela 12 mostram que em média o número amostral por população foi maior do que 25 para as três ordens. Contudo, quando se avalia os trabalhos em cada uma das 
espécies verifica-se uma variação grande do número amostral por população, sendo no mesmo trabalho populações com menos de 25 e populações com mais de 30. É importante atentar para que cuidados sejam tomados nos processos de amostragem para evitar resultados que possa gerar erros nos índices de variabilidade genética.

Outra questão importante nos estudos genéticos populacionais para identificação de estoques é a importância da estratégia de amostragem a ser conduzida (ABAUNZA et al., 2008). O primeiro passo é estabelecer os objetivos e as hipóteses a serem testadas antes dos trabalhos de campos sejam conduzidos. O conhecimento de parâmetros biológicos da espécie, tais como tipo de reprodução, período reprodutivo, distribuição geográfica e as possíveis barreiras naturais e/ou artificiais que separam suas populações é de suma importância para obter índices mais representativos de diversidade genética. No planejamento da amostragem a variação espacial e temporal deve ser considerada dentro da área de ocorrência das populações de uma dada espécie de forma a poder identificar os limites de diferenciação populacional. Muitas vezes dependendo das características da espécie se faz necessário a repetição amostral em um mesmo período. Isto é particularmente importante para espécies migradoras de peixes de água doce neotropical, visto que o período de menos chuvas correspondem a momento de se encontram as chamadas populações residentes e no período de chuvas ao momento de piracema. A hipótese do fenômeno de ondas migratórias diferenciadas a partir de uma mesma população residente em peixes migradores neotropicais pode gerar diferenciação populacional dentro de uma mesma população local (MORELLI et al., 2007; SANCHES; GALETII-JR, 2012)

DeWoody e Avise, (2000), produziram uma revisão comparativa entre parâmetros de diversidade genética produzida por STR. Neste trabalho foram comparados dados de peixes de água doce, de águas marinhas e de peixes anádromos com outros animais. Especificamente, para peixes de água doce, foram avaliadas 13 espécies (na sua maioria de peixes do hemisfério norte). Uma comparação dos valores médios de heterozigosidade por espécie e os valores do número médio de alelos por lócus deste trabalho com os produzidos pelos trabalhos de caracterização de lócus de espécies neotropicais são mostrados na tabela 13.

Tabela 13. Variação genética de lócus STR em peixes de água doce e outros animais.

\begin{tabular}{lcccc}
\hline \multicolumn{1}{c}{ Grupo } & No. de lócus & No. de espécies & $\boldsymbol{A}$ & $\boldsymbol{H}$ \\
\hline Peixes hemisfério norte* & 75 & 13 & $9,1(6,1)$ & $0,54(0,25)$ \\
Peixes neotropicais** & 535 & 43 & $9,8(4,4)$ & $0,68(0,14)$ \\
Peixes anádromos* & 43 & 7 & $10,8(6,6)$ & $0,68(0,12)$ \\
Peixes marinhos* & 66 & 12 & $19,9(6,6)$ & $0,77(0,19)$ \\
Outros animais* & 340 & 46 & $7,7(4,6)$ & $0,60(0,16)$ \\
\hline
\end{tabular}

*DeWoody e Avise (2000); **presente estudo; $A$ : número médiode alelos por lócus; $H$ : heterozigosidade média por espécie. 
A comparação dos dados de variação genética de peixes neotropical representada pelo número médio de alelos por lócus $(A)$ e heterozigosidade esperada média $(H)$ mostrou que os valores de $A$ foram ligeiramente superiores, mas não estatisticamente significativo ( $p>0,05$ ) quando comparado com os peixes do hemisfério norte, já $H$ de peixes neotropicais foi estatisticamente superior $(\mathrm{p}<0,05)$ a de peixes do hemisfério norte e igual a dos peixes marinhos. DeWoody e Avise (2000), atestaram que os valores maiores de diversidade genética apresentada pelos peixes marinhos refletem a tamanhos efetivos populacionais maiores de peixes marinhos quando comparado com os de água doce, que por estarem confinados em bacias hidrográficas em um período evolucionário mais curto a moderado apresentariam menores ou pelo menos iguais tamanho efetivo populacional.

Isto parece não ser totalmente verdadeiro quando peixes neotropicais são utilizados na comparação, pois o valor médio de heterozigosidade é igual ao dos peixes marinhos mesmo com um número médio inferior de alelos por lócus. Ao contrário do que propõem para a redução populacional de peixes de água doce de regiões temperadas devido às mudanças climáticas mediadas pelos efeitos da última era glacial ocorrido no último período do Pleistoceno, tais flutuações entre períodos glaciais e interglaciais afetaram de forma diferente os peixes neotropicais. Nos ambientes neotropicais, refúgios (AB'SABER, 1977; SIMPSON; HAFFER, 1978; BROWN; AB'SABER, 1979; HAFFER, 1982) teriam sido formados fragmentando as espécies em populações alopátricas, o que levou muitos delas a especiação e outras a expandirem seus locais de ocorrência ao longo dos ciclos paeloclimáticos sem necessariamente terem se especiado. Dependendo das particularidades da espécie e modo com que os refúgios são conectados, contatos entre refúgios próximos possivelmente permitiam migrações entre populações adjacentes. A maior diversidade genética encontrada nos peixes neotropicais que em peixes temperados é uma tendência também encontrada em outros vertebrados em latitudes inferiores (MARTIN; MCKAY, 2004; ADAMS; HADLY, 2013). Há uma tendência de que as políticas de conservação tenham com alvo a preservação das espécies. Contudo, a manutenção da biodiversidade depende em última instância da diversidade genética encontrada nas diferentes populações de uma espécie, e o que se observa atualmente é a extinção de populações locais que será determinante para a extinção de uma espécie (HUGHES et al., 1997). 


\section{Capítulo IV - Considerações finais}

\subsection{Considerações finais}

A conservação e manutenção da biodiversidade no nosso planeta passam por duas concepções. Uma mais de cunho ético e moral que é o direito a vida que todas as espécies têm de compartilhar nosso planeta com o homem, apesar deste último ter a capacidade de alterar o meio ambiente a seu favor em detrimento de outras espécies. Por outro lado, uma segunda concepção é de cunho mais pragmático e se baseia na conservação dos recursos biológicos e do meio ambiente para o bem estar do próprio homem. Sendo assim, as medidas de preservação das espécies e dos recursos naturais tornam-se importantes para produção de alimentos e outros subprodutos, bem como protegem o homem de desastres naturais. Independente de qual é a posição a ser escolhida; o importante é que as medidas de conservação dos recursos genéticos e a consciência de sua importância para o público em geral permitema busca de um equilíbrio entre desenvolvimento e conservação.

Peixes tem sido uma importante fonte de alimentos e de geração de emprego e renda para diversas comunidades ao redor do mundo (TACON; METIAN, 2013). A FAO tem discutido a importância da conservação dos recursos genéticos aquáticos desde a década de 1970 em publicações (FAO, 1972; 1981), o que mostra a preocupação da principal organização internacional responsável pelas questões da produção de alimentos no mundo em relação à sustentabilidade de tais recursos a médio e longo prazos. Em 1980, um documento importante foi gerado que destaca que as diversidades genéticas intra e interespecífica de peixes têm sido cada vez mais ameaçadas. O documento da FAO/UNEP (1981) destaca que as seguintes questões deveriam ser aprofundadas pelos responsáveis não somente pelo estabelecimento de políticas públicas, mas também por todos aqueles que fazem dos recursos genéticos um meio de produção: (i) considerar em profundidade os problemas que necessitam de ações para conservação dos recursos genéticos de peixes; (ii) desenvolver um consenso científico sobre as necessidades e sobre as estratégias para resolver os problemas; (iii) propor um plano de ação a metodologias apropriada para levar encaminhar tais problemas.

Os ecossistemas de águas continentais estão entre os mais ameaçados do planeta, esta realidade é particularmente importante para a ictiofauna presente em bacias hidrográficas da região neotropical. Nogueira et al. (2010), destacaram que em 540 drenagens de diversos portes no Brasil foram detectada 819 espécies de peixes com restrita ocorrência, sendo que muitas destas drenagens estão altamente alteradas. Isto coloca tamanha ictiodiversidade em risco de extinção e que de certa forma também compromete a sobrevivência de outras espécies que estão inter-relacionadas, muitas delas de importância direta para o homem. 
Como destacado ao longo do presente trabalho, os recursos genéticos de peixes, aqui especificamente de água doce, não estão somente baseados na diversidade interespecífica, mas também, no que concerne a viabilidade a longo prazo da espécie que é a diversidade interpopulacional.Populações locais são susceptíveis a fragmentação ambiental e tal realidade está cada vez mais presente nas bacias hidrográficas brasileiras devido às pressões econômicas por geração de energia para o crescimento econômico e ocupação populacional de regiões próximas aos recursos hídricos.

A aquicultura e a pesca em todos os países dentro da região neotropical são potenciais fontes de desenvolvimento e produção de alimentos. No Brasil particularmente, a região norte e a região central tem na atividade da pesca uma fonte importante de alimento e emprego (HILSDORF et al., 2006), por outro lado a aquicultura que até algumas décadas atrás não apresentava índices de destaque na produção nacional de proteína animal vem aumento sua contribuição na produção de pescado com um incremento de $35 \%$ na última década (MPA, 2013). Apesar de grande parte da produção de peixes de cativeiro ser de espécies introduzidas (tilápia e carpa) tem-se observado um aumento da contribuição de peixes nativos advindo da piscicultura na comercialização de pescado. Um exemplo disto é o tambaqui na região norte. Somente na região de Manaus, o tambaqui de cativeiro consumido pela população local já chega a 90\% e a produção estimada na região amazônica é de 8 mil toneladas anuais, o que ultrapassa as 4 mil toneladas produzidas em todo o país (INOUE; BOIJINK, 2011). Isso demonstra que a aquicultura pode ser um meio de produção de alimentos importante para a preservação dos recursos genéticos nativos por aliviar a pressão sobre os estoques pesqueiros, possibilitando a recuperação das populações selvagens que são a permanente fonte de variabilidade genética para os programas de melhoramento dos plantéis de cativeiro.

A aquicultura por outro lado também pode ser fonte de erosão dos recursos genéticos das populações selvagens. O escape de peixes oriundos de piscicultura pode ser fonte de contaminação genética sobre as populações naturais. Plantéis de cativeiro são submetidos a melhoramento genético mesmo que de forma não intencional, o que leva a modificar as frequências da composição gênica favorecendo genes de interesse para produção em detrimento dos genes evolutivamente selecionados no ambiente natural (GROSS, 1998). Como discutido anteriormente, o problema da produção de híbridos interespecíficos produzidos em larga escala por pisciculturas como método de melhoramento genético já que o cruzamento de duas espécies possibilita a produção de uma progênie que expresse características das duas espécies é altamente desejada e economiza gerações de programas de seleção (BARTLEY et al., 2001). O problema é que o seu escape destes híbridos pode causar um sério risco de contaminação genética sobre as 
populações selvagens (PORTO-FORESTI et al., 2011, PRADO et al., 2012). Esta é uma realidade presente na piscicultura nacional e que deve ser debatida com profundidade face as consequências futuras que o escape contínuo de híbridos podem acarretar para os recursos genéticos de espécies nativas de peixes no Brasil.

A presente revisão sobre oconjunto de publicações na área de genética populacional de peixes de água doce no Brasil e em países da região neotropical trouxe a tona alguns aspectos importantes em relação à conservação e uso dos recursos genéticos ictíicos. A copilação dos resultados dos diferentes marcadores genéticos usados mostrou que:

(i) Face à significativa diversidade de espécies de peixes de água doce, os trabalhos se concentram em poucas espécies;

(ii) Os estudos de forma geral, com algumas excessões, mostram resultados de diferenciação populacional de áreas isoladas;

(iii) Muitos dos estudos foram realizados com um número baixo de lócus microssatélites ou com regiões mitocondriais não recomendadas para estudos populacionais;

(iv) Apesar do número médio do tamanho amostral estar adequado, muitos trabalhos apresentaram número amostral baixo, o que dificulta entender a real situação de diversidade genética da espécie na região avaliada para monitoramento futuros;

(v) Os estudos na grande maioria são direcionados para a avaliação da diferenciação genética populacional em áreas afetadas por disturbios ambientais, poucos foram os trabalhos que avaliaram os resultados dentro da perspectiva do uso dos recursos genéticos em programas de repovoamento e melhoramento;

(vi) Poucos foram os estudos principalmente com microssatélites direcionados para populações de espécies de peixes em cativeiro para se medir níveis de variabilidade e endogamia dos plantéis;

(vii) Os resultados de marcadores microssatélites com espécies da ordem dos Siluriformes mostraram uma tendência à estruturação genética. Este achado deve ser levado em consideração em programas de conservação e melhoramento, pois tal diferenciação pode representar adaptações locais (JERRY et al., 2002).

(viii) O índice de diferenciação genética populacional quando ajustado por Hedrick (2005), o qual promove um ajuste do índice $\mathrm{F}_{S T}$ com base na média da heterozigosidade esperada sob o equilíbrio de Hardy-Weinberg, resultou em valores mais elevados de $\mathrm{F}_{S T}$ dos que os verificados nos cálculos convencionais de obtenção dos índices de fixação atualmente utilizados. Isto sugere que populações de peixes de água doce neotropicais podem apresentar diferenciação não 
somente devido à separação de bacias e barreiras naturais, que diretamente reduz o fluxo gênico entre populações, mas também fatores como: diferenças em latitudes, temperatura, sistema hidrológico, disponibilidade de alimentos e estratégias reprodutivas que podem levar a seleção, adaptação local e aumento de diferenciação populacional.

(ix) Houve uma clara tendência do abandono de marcadores como RAPD e um aumento do uso de análise de sequências de DNA mitocondrial, principalmente da região do D-loop e de marcadores microssatélites;

(x) Um único trabalho sobre genética de populações com o uso de SNP foi encontrado (WILLING et al., 2010) com lebistes. Este marcador consiste em mutações de ponto que aparecem a cada 300 a 1.000 nucleotídeos (BROOKES, 1999). O fato de ainda não haver estudos para gerar painéis de SNPs de espécies neotropicais, ainda não popularizou este marcador para abordagens populacionais como em outras espécies, por exemplo, o bagre de canal norteamericano (HE et al., 2003).

A importância dos recursos genéticos de peixes de água doce na região neotropical é uma premissa indiscutível nos diversos níveis de interesse da sociedade. Os especialistas devem por isso concentrar esforços no sentido de gerar dados que fundamentem políticas de conservação e uso sustentado de tais recursos. Medidas devem ser tomadas para que populações locais de peixes de interesse econômico ou não sejam preservadas per se. Algumas recomendações e estratégias são sugeridas para que o uso de marcadores genéticos possa ser uma ferramenta importante nas tomadas de decisões:

(i) Para estudos populacionais com a utilização de DNA mitocondrial deve ser utilizada a região do D-loop mitocondrial, principalmente a primeira metade a partir do RNA transportador da prolina (região hipervariável);

(ii) Gerar iniciadores "universais" da região do D-loop mitocondrial para grupos de peixes principalmente aqueles que necessitem monitoramento genético com o objetivo de gerar dados temporais sobre as populações de peixes afetadas pela pesca e distúrbios ambientais.

(iii) O número amostral pequeno pode ser um limitante para conclusões mais confiáveis com o uso do DNAmt, pois um número amostral pequeno pode não representar o total a diversidade nucleotídica e haplotípica das populações em estudo;

(iv) Em estudos com STRs procurar utilizar um número mínimo de 25 indivíduos por amostragem em cada população;

(v) O planejamento amostral é fundamental para se conseguir respostas ao tipo de objetivo que se busca: verificar homing (TELLES et al., 2011) diferenciação genética em populações migrantes 
(ondas migratórias), verificar impactos de mudanças ambientais sobre as populações naturais, entendimento da distribuição genética para formação de banco de reprodutores para programas de repovoamento entre outros.

(vi) Ainda não há um consenso sobre o número mínimo de lócus microssatélites a serem usados em análises genético populacionais. Kalinowski (2002), sugere que a precisão dos resultados de diferenciação genética entre populações depende do número de alelos presentes nos lócus a serem utilizados, pois lócus mais polimórficos resultam em melhores estimativas de distância genética do que lócus menos polimórficos. Desta forma, estimativas mais precisas de diferenciação genética são conseguidas com a utilização de menos lócus com muitos alelos ou muitos lócus com muitos alelos. Aqui é importante salientar que a escolha de lócus que estejam preferencialmente em grupos de ligações diferentes do genoma da espécie ou em equilíbrio de ligação, pois lócus em desequilíbrio de ligação estão provavelmente ligados e gera menos informação sobre a variabilidade genética do que dois lócus independentes. Neste item, é importante salientar que apesar do aumento de publicações de lócus STRs em espécies de peixes neotropicais, ainda não há nenhum mapa de ligação publicado de nenhuma destas espécies.

(vii) Estudos genéticos populacionais mais direcionados devem ser conduzidos em espécies de peixes nativos de interesse para piscicultura no sentido de se conhecer a distribuição das diferenças genéticas entre populações nas regiões de ocorrência da espécie para se identificar populações fisiológicas (raças fisiológicas) que pode ser usadas em programas de melhoramento genético;

(viii) Cuidados devem ser tomados no uso de STRs durante a genotipagem das populações e que podem levar a erros e distorcer os resultados encontrados. Pompanon et al. (2005), discutem os erros suas causas e soluções que são listados em uma publicação da FAO (FAO, 2011) que apesar de ser voltada para os recursos genéticos de animais terrestres pode ser aplicada para peixes e outros organismos aquáticos.

(ix) Estudos devem ser realizados para gerar painéis de marcadores SNPs de espécies de peixes neotropicais que no futuro deverá ser utilizado com mais frequência em estudos de variabilidade genética de populações naturais e também em programas de melhoramento genético (WILLING et al., 2012; CAETANO 2009).

(x) Por último, no último workshop patrocinado pela FAO e World Fisheries Trust sobre o status e as tendências dos recursos genéticos aquáticos (BARTLEY et al., 2006) destaca que apesar do progresso que tem sido feito nas áreas de melhoramento genético, identificação de estoques e genômica de espécies aquáticas, aspectos importantes do conhecimento e conservação destes recursos devem ser perseguidos, e isto é especialmente relevante para espécies neotropicais 
(observação do autor neste trabalho) entre estes estão: (i) avaliar o status dos FiGR (fish genetic resources); (ii) melhorar o conhecimento de cientistas, público, governo e setor produtivo sobre a importância do FiGR; (iii) expandir as condições de infraestrutura para caracterizar os FiGR; (iv) desenvolver variedades ou raças de peixes melhoradas geneticamente para o desenvolvimento de piscicultura de espécies nativas; (v) desenvolver políticas e instrumentos apropriados para o uso e conservação dos FiGR; (vi) aumentar a conscientização e níveis de conhecimento sobre FiGR; (vii) priorizar espécies, área geográficas e sistemas de produção sobre os quais devem ser gastos os recursos para conservação e uso dos FiGR. 


\section{Referências bibliográficas}

ABAUNZA, P.; MURTA, A. G.; CAMPBELL, N.; CIMMARUTA, R.; COMESAÑA, A.S.; DAHLE, G.; GALLO, E.; GARCÍA-SANTAMARÍA, M. T.; GORDO, L. S.; IVERSEN, S. A.; MACKENZIE, K.; MAGOULAS, A.; MATTIUCCI, S.; MOLLOY, J.; NASCETTI, G.; PINTO, A. L.; QUINTA, R.; RAMOS, P.; RUGGI, A.; SANJUAN, A.; SANTOS, A. T.; STRANSKY, C.; ZIMMERMANN, C. Considerations on sampling strategies for an holistic approach to stock identification: The example of the HOMSIR project. Fisheries Research, v. 89, p. 104-113, 2008.

ABDELKRIM J.; ROBERTSON B. C.; STANTON J-AL.; GEMMELL N. J. Fast, cost effective development of species-specific microsatellite markers by genomic sequencing. Bio Techniques, v. 46, p. 185-191, 2009.

ABREU, M.M.; PEREIRA, L.H.G.; VILA, V.B.; FORESTI, F.; OLIVEIRA, C. Genetic variability of two populations of Pseudoplatystoma reticulatum from the Upper Paraguay River Basin. Genetics and Molecular Biology, v. 32, p. 868-873, 2009.

AB'SABER, A. N. Espaços ocupados pela expensao dos climas secos na América do Sul, por ocasião dos períodos glaciais quatemários. Paleoclima (São Paulo) no. 3, 1977

ADAMS, M. W.; ELLINGBAE, A. H.; ROSSINEAU, E. C. Biological uniformity and disease epidemics. Bioscience v. 21, p. 1067-1070, 1971.

ADAMS, R. I.; HADLY, E. A. Genetic diversity within vertebrate species is greater at lower latitudes. Evolutionary Ecology, v. 27, p. 133-143, 2013

AIE (Agência Internacional de Energia). Key world energy statistics: from the IEA. Paris. 2003 Disponível em: <http://www.iea.org/textbase/nppdf/free/2004/keyworld2004.pdf>. Acesso em: 20 Set. 2010.

AGARWAL, M.; SHRIVASTAVA, M.; PADH, H. Advances in molecular marker techniques and their applications in plant sciences. Plant Cell Reports, v. 27, p. 617-631. 2008

ALBERT, J. S.; REIS, R. E. Historical Biogeography of Neotropical Freshwater Fishes. University of California Press, 2011, 308 p.

ALBERT, J. S.; CRAMPTON, W. G. The geography and ecology of diversification in neotropical freshwaters. Nature Education Knowledge, v. 3, p. 13. 2010

ALLENDORF F. W.; MITCHELL N.; RYMAN N.; STAHL G. Isozyme loci in brown trout (Salmo truttaL.): detection and interpretation for population data. Hereditas, v. 86, p. 179190. 1977.

ALLENDORF, F. W.; UTTER, F. M. Population genetics. In: HOAR, W. S., RANDALL, D. J. AND BRETT, J. R. (eds) Fish Physiology, 8, Academic Press, New York, 1979, p. $407-$ 453. 
ALLENDORF, F.W.; LEARY, R.F. Heterozygosity and fitness in natural populations of animals. In: SOULÉ, M.E. (ed.), Conservation biology: the science of scarcity and diversity. Sinauer Associates. Inc. Publishers, Sunderland, MA, USA, 1986. p. 57-76.

ALLENDORF, F. W.; LEARY, R. F.; SPRUELL, P.; WENBURG, J.K. The problems with hybrids: setting conservation guidelines. Trends in Ecology \& Evolution, v. 16, p. 613-622, 2001.

ALLEM, A. C. The terms genetic resource, biological resource, and biodiversity examined. The Environmentalist, v. 20, p. 335-341, 2000.

ALMEIDA, F. S., FUNGARO, M. H. P., SODRE, L. M. K. RAPD and isoenzyme analysis of genetic variability in three allied species of catfish (Siluriformes: Pimelodidae) from the Tibagi River, Brazil. Journal of Zoology (London), v. 253, p. 113-120, 2001.

ALMEIDA, F. S.; SODRÉ, L. M. K.; CONTEL, E. P. B. Population structure analysis of Pimelodus maculatus (Pisces, Siluriformes) from the Tietê and Paranapanema Rivers (Brazil). Genetics and Molecular Biology, v. 26, p. 301-305, 2003.

ALMEIDA-VAL, V.M.F.; VAL, A.L.; HOCHACHKA, P.W. Hypoxia tolerance in amazon fishes: status of an under explored biological. IN: Peter, W.; Hochachka, P.L.; Sick, T.; Rosenthal, M.; Thillart, G.V.D. (eds), Surviving Hypoxia: Mechanisms of Control and Adaptation. CRC Press Inc., Boca Raton, FL, USA. 1993. p. 435-445.

ALTUKHOV, YU .P.; LIMANSKY, V. V.; PAYUSOVA, A. N.; TRUVELLER, K. A. Immunogenetical analysis of intraspecies differentiation of the European anchovy from the Black and Azov Seas. II Elementary populations of anchovy and their place in geneticpopulational structure of species. Genetics, URSS, v. 6, p. 265-278, 1969.

ALTUKHOV, Y.P. 1981. The stock concept from the view point of population genetics. Canadian Journal of Aquatic Sciences, v. 38, p. 1523-1538, 1981.

ALVES, C. B. M.; VIEIRA, F.; MAGALHÃES, A. L. B.; BRITO, M. F. G. Impacts of NonNative Fish Species in Minas Gerais, Brazil: Present Situation and Prospects. In: BERT, T.M., (ed.), Ecological and Genetic Implications of Aquaculture Activities-Methods and Technologies in Fish Biology and Fisheries, V. 6, p. 291-314, 2007.

AMADO, M. V.; HRBEK, T.; GRAVENA, W.; FANTIN, C.; ASSUNÇÃO, E. N.; ASTOLFIFILHO, S.; FARIAS, I. P. Isolation and characterization of microsatellite markers for the ornamental discus fish Symphysodon discus and cross-species amplification in other Heroini cichlid species. Molecular Ecology Resources v. 8, p. 1451-1453, 2008.

ANEEL. Agência Nacional de Energia Elétrica (Brasil). Atlas de energia elétrica do Brasil, $3^{a}$. Edição, Agência Nacional de Energia Elétrica, Brasília, 2008. 263 p. 
AQUABRASIL. Bases tecnológicas para o desenvolvimento sustentável da aquicultura no

Brasil: Disponível em <http://www.macroprograma1.cnptia.embrapa.br/aquabrasil>. Acesso em: 13 fev 2013.

AQUADRO, C. F.; GREENBERG, B. D. Human mitochondrial DNA variation and evolution: analysis of nucleotide sequences from seven individuals. Genetics, v. 103, p. 287-312, 1983.

AVILA, I. G.; KOLDENKOVA, L.; MUSTELIER, J. C. G. Cyprinodon variegatus (Cyprinodontiformes: Cyprinodontidae), bio-regulator of mosquito larvae of Aedes taeniorbynchus and Culex bahamensis in the isle of youth, Cuba. Memórias do Instituto Oswaldo Cruz, v. 87, p. 461 1992. (Resarch Note).

AVISE, J. C. Molecular markers, natural history, and evolution. Second edition. Sinauer Associates, Inc. Sunderland, Massachusetts, 2004. 684 p.

BALLARD, J. W.; KREITMAN, M. Is mitochondrial DNA a strictly neutral marker?Trends in Ecology and Evolution, v. 10, p. 485-488 1995.

BALON, E. K. Origin and domestication of the wild carp, Cyprinus carpio: from Roman gourmets to the swimming flowers. Aquaculture v. 129, p. 3-48, 1995.

BARBOSA, A. C. D. R.; CORRÊA, T. C.; GALZERANI, F.; GALETTI-JR., P.N.; HATANAKA, T. Thirteen polymorphic microsatellite loci in the Neotropical fish Prochilodus argenteus (Characiformes, Prochilodontidae). Molecular Ecology Notes, v. 6, p. 936-938 2006.

BARBOSA, A. C. D. R.; GALZERANI, F.; CORREAA, T.C.; GALETTI-JR.; P.M., HATANAKA, T. Description of novel microsatellite loci in the Neotropical fish Prochilodus argenteus and cross-amplification in P. costatus and P. lineatus. Genetics and Molecular Biology, v. 31, (suppl), p. 357-360, 2008.

BARLET'T, P. F. Adaptation strategies in peasant agricultural production. Annual Review of Anthropology, v. 9, p. 545-573, 1980.

BARLETTA, M.; JAUREGUIZAR, A. J.; BAIGUN, C.; FONTOURA, N. F.; AGOSTINHO, A. A.; ALMEIDA-VAL, V. M. F.; VAL, A. L.; TORRES, R. A.; JIMENES-SEGURA, L. F.; GIARRIZZO, T.; FABRÉ, N. N.; BATISTA, V. S.; LASSO, C.; TAPHORN, D. C.; COSTA, M. F.; CHAVES, P. T.; VIEIRA, J. P.; CORREAA, M. F. M. Fish and aquatic habitat conservation in South America: a continental overview with emphasis on neotropical systems. Journal of Fish Biology,v. 76, p. 2118-2176, 2010.

BARroso, R. M.; HILSDORF, A. W. S.; MOREIRA, H. L. M.; MELLO, A. M.; GUIMARÃES, S. E. F.; CABELLO, P. H.; TRAUB-CSEKO, Y. M. Identification and characterization of microsatellites loci in Brycon opalinus (Cuvier, 1819) (Characiforme, Characidae, Bryconiae). Molecular Ecology Notes, v. 3, p. 297-298, 2003. 
BARROSO, R. M.; HILSDORF, A. W. S.; MOREIRA, H. L. M.; CABELLO, P. H.; TRAUBCSEKO, Y. M. Genetic diversity of wild and cultured populations of Brycon opalinus (Cuvier, 1819) (Characiforme, Characidae, Bryconiae) using microsatellites. Aquaculture, v. 247, p. $51-65,2005$.

BARSON, N. J.; CABLE, J.; VAN OOSTERHOUT, C. Population genetic analysis of microsatellite variation of guppies (Poecilia reticulata) in Trinidad and Tobago: evidence for a dynamic source-sink metapopulation structure, founder events and population bottlenecks. Journal of Evolutionary Biology v. 22, p. 485-497, 2009.

BARTLEY, D. M.; PULLIN, R. S.V. Aquatic genetic resources policy. In: PULLIN, R.S.V.; BARTlEY, D.M.; KOOIMAN, J. (eds). Towards Policies for Conservation and Sustainable Use of Aquatic Genetic Resources. ICLARM Conf. Proc. 59, Manila, Philippines, 1999. 1-16 p.

BARTLEY, D. M., RANA, K., IMMINK, A. J. The use of inter-specific hybrids in aquaculture and fisheries. Reviews in Fish Biology and Fisheries, v. 10, p. 325-337, 2001.

BARTLEY, D.M.; HARVEY, B.J.; PULLIN, R.S.V. (eds). Workshop on Status and Trends in Aquatic Genetic Resources: a Basis for International Policy. 8-10 May 2006, Victoria, British Columbia, Canada. FAO Fisheries Proceedings.No. 5. Rome, FAO. 2007. 179p.

BARTLEY, D.M., NGUYEN, T.T.T., HALWART, M., SILVA, S.S. Use and exchange of aquatic genetic resources in aquaculture: information relevant to access and benefit sharing. Reviews in Aquaculture, v.1, p. 157-16. 2009.

BASAVARAJU Y.; PENMAN D.J.; MAIR, G.C. Genetic status and strategies for improvement of common carp (Cyprinus carpio) in Karnataka, India - Evaluation of stocks for the development of a breeding programme. In: PENMAN, D. J.; HUSSAIN, M. G.; MCANDREW, B. J.; MAZID, M. A. (eds), Proceedings of a Workshop on Genetic Management and Improvement Strategies for Exotic Carps in Bangladesh. Bangladesh Fisheries Research Institute, Mymensingh, 2002. p. 29-36.

BATISTA, J. S.; ALVES-GOMES, J.A. Phylogeography of Brachyplatystoma rousseauxii (Siluriformes - Pimelodidae) in the Amazon Basin offers preliminary evidence for the first case of "homing" for an Amazonian migratory catfish. Genetics and Molecular Research, v. 5, p. 723-740, 2006.

BATISTA, J. S. Caracterização genética da dourada - Brachyplatystoma rousseauxii, Castelnau, 1855 (Siluriformes-Pimelodidae) na Amazônia por meio de marcadores moleculares mitocondriais e microssatélites: subsídios para conservação e manejo. 2010. 148 f. Tese Doutorado, INPA, Manaus, 2010. 
BATISTA, J. S.; FARIAS, I. P.; FORMIGA-AQUINO, K.; SOUSA, A. C. B.; ALVES-GOMES, J. A.; DNA microsatellite markers for "dourada" (Brachyplatystoma rousseauxii, Siluriformes: Pimelodidae), a migratory catfish of utmost importance for fisheries in the Amazon: development, characterization and inter-specific amplification. Conservation Genetic Resources, v. 2, p. 5-10, 2010.

BEARDMORE, J.A.; MAIR, G.C.; LEWIS, R.I. Biodiversity in aquatic systems in relation to aquaculture. Aquaculture Research, v.28, p.829-839, 1997.

BECKENBACH, A.T., Rapid mtDNA sequence analysis of fish populations using the polymerase chain reaction (PCR). Canadian Journal of Fisheries and Aquatic Science, 48 (Suppl. 1): p. 95-98, 1991.

BECKER, S. A. B.; MAGURRAN, A. E. Gene flow in Trinidadian guppies. Journal of Fish Biology, v. 56, p. 241-249. 2000.

BECHER, S. A., RUSSELL, S. T., MAGURRAN, A. E. Isolation and characterization of polymorphic microsatellites in the Trinidadian guppy (Poecilia reticulata). Molecular Ecology Notes, v. 2, p. 456-458, 2002.

BEGG, G.A.; FRIEDLANDB, K.D.; PEARCE, J.B. Stock identification and its role in stock assessment and fisheries management: an overview. Fisheries Research, v.43, p. 1-8, 1999.

BEHEREGARAY, L. B., SCHWARTZ, T. S., MÖLLER, L. M., CALL, D., CHAO, N. L., CACCONE, A.A set of microsatellite DNA markers for the one-lined pencilfish Nannostomus unifasciatus, an Amazonian flooded forest fish. Molecular Ecology Notes, v. 4 p. 333-335, 2004.

BEHEREGARAY, L. B., MÖLLER, L. M., SCHWARTZ, T. S., CHAO, N. L., CACCONE, A., Microsatellite markers for the cardinal tetra Paracheirodon axelrodi, a commercially important fish from central Amazonia. Molecular Ecology Notes, v. 4, p. 330-332, 2004.

BEHEREGARAY, L. B.; CHAE, J.; CHAO, N. L.; CACCONE, A. Characterization of microsatellite loci for the Amazonian rummy-nose tetra, Hemigrammus bleheri (Teleostei, Characidae). Molecular Ecology Notes, v. 5, p. 536-537, 2005.

BeHEREgARAY, L. B.; PIGGOTT, M.; CHAO, N. L.; CACCONE, A. Development and characterization of microsatellite markers for the Amazonian blackwing hatchetfish, Carnegiella marthae (Teleostei, Gasteropelecidae). Molecular Ecology Notes, v. 6, p. 787788, 2006.

BENECKE, N. Studies on early dog remains from Northern Europe. Journal of Archaeological Science, v. 14, p. 31-49, 1987.

BENITES, C. Caracterização genética do pintado, Pseudoplatystoma corruscans (Siluriformes: Pimelodidae) da Bacia hidrográfica Paraná-Paraguai, por marcadores 
moleculares tipo microssatélite. 2008. 88 f. Tese de Doutorado. Curso de Pós-Graduação em Aquicultura, Centro de Aqüicultura da Universidade Estadual Paulista, Jaboticabal, SP, Brasil, 2008.

BENTSEN, H. B.; EKNATH; A. E.; PALADA-DE VERA, M. S.; DANTING, J. C.; BOLIVAR, H. L.; REYES, R. A.; DIONISIO, E. E.; LONGALONG, F. M.; CIRCA, A. V.; TAYAMEN, M. M.; GJERDE, B. Genetic improvement of farmed tilapias: growth performance in a complete diallel cross experiment with eight strains of Oreochromis niloticus. Aquaculture, v. 160, p. 145-173, 1998.

BERMINGHAM E., MARTIN, A. P. Comparative mtDNA phylogeography of neotropical freshwater fishes: testing shared history to infer the evolutionary landscape of lower central America. Molecular Ecology, v. 7, p. 499-517, 1998.

BERNATCHEZ, L.; SAVARD, L.; DODSON, J. J.; PALLOTA, D. Population bottleneck: influence on mitochondrial DNA diversity and its effects in coregonine stock discrimination. Journal of Fish Biology, v. 35 (suppl. A): p. 233-244, 1989.

BERRA T. M. An atlas of distribution of the freshwater fish families in the world. University of Nebraska Press, Lincon, London 1981. 197 p.

Bertollo L. A. C.; BORN G. G.; DERGAM J. A.; FENOCCHIO A. S.; MOREIRAFILHO, O. A biodiversity approach in the Neotropical Erithrinidae fish, Hoplias malabaricus. Karyotypic survey, geograpic distribution of karyotypes and cytotaxonomic considerations. Chromosome Research, v. 8, p. 603-613, 2000.

BILlingtON, N.; HEBERT, P. D. N. Mitochondrial DNA diversity in fishes and its implications for introductions. Canadian Journal of Fisheries and Aquatic Science, v. 48, p. 80-94, 1991.

BIRKY, C. W. Transmission genetics of mitochondria and chroloplasts. Annual Review of Genetics, v.12, p. 471-512, 1978.

BONGA, S.E.W. The stress response in fish. Physiological Reviews, v. 77, p. 591-625, 1997

BOEHLERT, G. W. Biodiversity and marine fisheries the sustainability of marine fisheries. Oceanography, v. 9, p. 28-35, 1996.

BOGENHAGEN, C. W.; CLAYTON, D. A. The number of mitochondrial deoxyribonucleic acid genome in mouse L and human HeLa cells. Journalof Biological Chemistry, v. 294, p. 471-512, 1974.

BREWER, G. J. An Introduction to Isozyme Techniques, Academic Press, New York. 1970. $186 \mathrm{p}$.

BRITSKI, H.A.; SILIMON, K.Z.; LOPES, B.S. Peixes do Pantanal - Manual de Identificação. 2ed. Embrapa Pantanal, Corumbá, MS, Brasil, 2007. 184 p. 
BROCKHAUS, R.; OETMANN, A. Aspects of the documentation of in situ conservation measures of genetic resources. Plant Genetic Resources Newsletter, v. 108, p. 1-16, 1996. BROOKES, A. J. The essence of SNPs. Gene, v. 234, p. 177-186, 1999.

BROWN W. M.; VINOGRAD J. Restriction endonuclease cleavage maps of animal mitochondrial DNAs. Proceedings of the National Academy of Sciences USA, v. 71, p. 4617-4621, 1974.

BROWN, K. S.; AB'SABER, A. N. Ice-age forest refuges and evolution in the neotropics: correlation of paleoclimatological, geomorphological and pedological data with modem biological endemism. Paleoclimas (São Paulo) No. 5, 1979.

BROWN W. M.; PRAGER E. M.; WANG A.; WILSON A. C. Mitochondrial DNA sequences of primates: tempo and mode of evolution. Journal of Molecular Evolution, v. 18, p. 225239, 1982.

BROWN, W. M. Evolution of animal mitochondrial DNAs. In: NEI, M., KOEHN; R. K., (eds). Evolution of genes and proteins, Sinauer, Sunderland, MA, 1983. p. 62-68.

BROWN W. M. The mitochondrial genome of animals, In: MACINTYRE, R. J. (ed.). Molecular Evolutionary Genetics, Plenum Press, New York, 1985. p. 95-130.

BUCKUP P.; MENEZES N.; GHAZZI, M. Catálogo das espécies de peixes de água doce do Brasil. Rio de Janeiro, Brazil, Museu Nacional. 2007.195 p.

BURKE, T.; BRUFORD, M. W. DNA fingerprinting in birds. Nature, v. 32, p. 149-152. 1987.

BUTH, D. G.; BURR, B. M. lsozyme variability in the cyprinid genus Campostoma, Copeia, v. 2, p. 298-311, 1978.

CAETANO-ANOLLE'S, G.; BASSAM, B. J. D. N. A. Amplification fingerprinting using arbitrary oligonucleotide primers. Applied Biochemistry and Biotechnology, v. 42, p. 189-200. 1993.

CAETANO, A. R. Marcadores SNP: conceitos básicos, aplicações no manejo e no melhoramento animal e perspectivas para o futuro. Revista Brasileira de Zootecnia, v.38, p.64-71 (supl. Especial), 2009.

CAlCAGNOT'TO, D. Caracterização de bancos genéticos selvagens de Pacu (Piaractus mesopotamicus) e de Tambaqui (Colossoma macropomum) através da análise de DNA mitocondrial. 1998, 131 f. Tese de Doutoramento, Instituto de Biociências, Universidade de São Paulo, São Paulo.

CALCAGNOTTO, D.; RUSSELlO, M.; DE SALLE, R. Isolation and characterization of microsatellite loci in Piaractus mesopotamicus and their applicability in other Serrasalminae fish. Molecular Ecology Notes, v. 1, p. 245-247, 2001. 
CALCAGNOTTO, D.; ROB DESALLE, R. Population genetic structuring in pacu (Piaractus mesopotamicus) across the Paraná-Paraguay basin: evidence from microsatellites. Neotropical Ichthyology, v. 7, p. 607-616, 2009.

CARDOSO, Y. P.; ALMIRÓN, A.; CASCIOTTA, J.; AICHINO, D.; LIZARRALDE, M. S.; MONTOYA-BURGOS, J. I. Origin of species diversity in the catfish genus Hypostomus (Siluriformes: Loricariidae) inhabiting the Paraná River basin, with the description of a new species. Zootaxa, v. 3453, p. 69-83, 2012.

CAROLSFELD, J.; HARVEY, B.; ROSS, C.; BAER, A. (eds). Migratory Fishes of South America: Biology, Fisheries and Conservation Status, Co-published by IDRC and the World Bank, Victoria, Canada, 2003. 372 p.

CARRILLO-AVILA, M.; RESENDE, E. K.; MARQUES, D. K. S.; GALETTI-JR., P.M., Isolation and characterization of polymorphic microsatellites in the threatened catfish Jaú, Zungaro jahu(Siluriformes, Pimelodidae). Conservation Genetics, v. 10, p. 1597-1599, 2009.

CARTER, R. E.; MAIR, G. C.; SKIBINSKI, D. O. F.; PARKIN, D. T.; BEARDMORE, J.A. The application of DNA fingerprinting in the analysis of gynogenesis of tilapia. Aquaculture, v. 95, p. 41-52, 1991.

CARVAJAL-VALLEJOS, F. M.; DUPONCHELlE, F.; BALLIVIAN, J. P. T.; HUBERT, N., RODRÍGUEZ, J. N.; BERREBI, P.; CORNEJO, S. S.; RENNO, J-F. Population genetic structure of Cichla pleiozona(Perciformes: Cichlidae) in the Upper Madera basin (Bolivian Amazon): Sex-biased dispersal? Molecular Phylogenetics and Evolution, v. 57, p. 1334 $1340,2010$.

CARVALHO, G. R.; SHAW, P. W.; MAGURRAN, A. E.; SEGHERS, B. H. Marked genetic divergence revealed by allozymes among populations of the guppy Poecilia reticulata (Poeciliidae), in Trinidad. Biological Journal of the Linnean Society, v. 42, p.389-405, 1991.

CARVALHO, G.R.; HAUSER, L. Molecular Genetics and the stock concept in fisheries. In: CARVALHO, G.R.; PITCHER, T.J. (eds.). Reviews in Fish Biology and Fisheries, v.4, p.326-350, 1994.

CARVALHO-COSTA, L. F., HATANAKA, T., GALETTI-JR., P. G. Isolation and characterization of polymorphic microsatellite markers in the migratory freshwater fish Procbilodus costatus. Molecular Ecology Notes, v. 6: p. 818-819, 2006.

CARVALHO-COSTA, L. F.; HATANAKA, T.; GALETTI-JR., P.G. Evidence of lack of population substructuring in the Brazilian freshwater fish Prochilodus costatus. Genetics and Molecular Biology, v. 31, (suppl 1): p. 377-380, 2008. 
CARVALHO, D. C.; BEHEREGARAY, L. B. Rapid development of microsatellites for the endangered Neotropical catfish Conorhynchus conirostrisusing a modest amount of 454 shotgun pyrosequencing. Conservation Genetic Resources, v. 3, p. 373-375, 2011.

CARVALHO, D. C.; OLIVEIRA, D. A. A.; BEHEREGARAY, L. B.; TORRES, R. A., Hidden genetic diversity and distinct evolutionarily significant units in a commercially important Neotropical apex predator, the catfish Pseudoplatystoma corruscans. Conservation Genetics, v. 13, p. 1671-1675, 2012.

CASTLE, W. E. The laws of Galton and Mendel and some laws governing race improvement by selection. Proceedings of the American of the Academy of Arts and Sciences, v. 35, p. 233-242, 1903.

CATELLA, A. C.; MASCARENHAS, R. O.; ALBUQUERQUE, S. P.; ALBUQUERQUE, F. F.; THEODORO, E. R. M. Sistemas de estatísticas pesqueiras no Pantanal, Brasil: aspectos técnicos e políticos. Pan-American Journal of Aquatic Sciences, v.3, p. 174-192. 2008.

CBD, 1992. Convention on Biological Diversity. Text and Annexes. United Nations Environment Programme, Rio de Janeiro, 5 June.

CHAMBERS, G. K., MACAVOY, E. S. Microsatellites: consensus and controversy. Comparative Biochemistry and Physiology Part B, v. 126, p. 455-476, 2000.

CHANG, R. Y., O’DONOUGHUE, L. S., BUREAU, T. E. Inter-MITE polymorphisms (IMP): a high throughput transposon-based genome mapping and fingerprinting approach.'Theoretical and Applied Genetics, v. 102, p. 773-781, 2001.

CHAPMAN, R. W.; POWERS, D. A. A method for the rapid isolation of mitochondrial DNA from fishes. Tech. Rep. UM-SG-TS-84-05, Maryland Sea Grant Program., Univ. Md., College Park, 1984, 11 p.

CHAKRABORTY, S. M.; LEIMAR, O. Genetic variation within a subdivided population. In: RYMAN, N.; UTTER, F. (eds). Population Genetics and Fishery Management, University of Washington Press, Seattle, 1987. P. 89-120.

CHIARI, L.; SODRÉ, L. M. K. Genetic variability in five species of Anostomidae (Ostariophysi Characiformes) Genetics and Molecular Biology, v. 22, p. 517-523, 1999.

CHIVIAN, E.; BERNSTEIN, A. (eds.) Sustaining life: How human health depends on biodiversity. Center for Health and the Global Environment. Oxford University Press, New York. 2008. 542 p.

CORONEL, J. S.; MAES, G. E.; CLAUS, S., VAN DAMME, P. A.; VOLCKAERT, F. A. M. Differential population history in the migratory catfishes Brachyplatystoma flavicansand Pseudoplatystoma fasciatum(Pimelodidae) from the Bolivian Amazon assessed with nuclear and mitochondrial DNA markers. Journal of Fish Biology, v.65, p. 859-868, 2004. 
CUSHING, J. E. Serological differentiation of fish bloods. Science, v. 115, p. 404-405, 1952.

CUSHING, J. E., Serology of tuna. U.S. Fish\&Wildlife. Service, Spec. Sci. Rept.: Fisheries, v. 183 , p. 1-14, 1956.

DA SILVA, C.J. Ecological basis for the management of the Pantanal- Upper Paraguay River Basin. In: SMITS, A.J.M.; NIENHUIS, P.H.; LEUVEN, R.S.E.W. (eds), New approaches toriver management. Blackhuys Publishers, Leiden, The Netherlands, 2000. p. 97-117.

DE LONGH, H. H.; VAN ZON, J. C. J. Assessment of impact of the introduction of exotic fish species in north-east Thailand. Aquaculture and Fisheries Management, v. 24, p. 279-289, 1993.

DERGAM, J.A.; HARUMI, I.S.; SHIBATTA, O.A.; DUBOC, L.F.; JÚLIO-JR., H.F.; GIULIANO-CAETANO, L.; BLACK IV, W.C. Molecular biogeography of the Neotropical fish Hoplias malabaricus (Erythrinidae:Characiformes) in the Iguaçu, Tibagi, and Paraná Rivers. Genetics and Molecular Biology, v. 21, p. 493-496, 1998.

DERGAM, J. A.; PAIVA, S. R.; SCHAEFFER, C. E.; GODINHO, A. L.; VIEIRA, F. Phylogeography and RAPD-PCR variation in Hoplias malabaricus (Bloch, 1794) (Pisces, Teleostei) in southeastern Brazil. Genetics and Molecular Biology, v. 25, p. 379-387, 2002

DESMARAIS, E.; LANNELUC, L.; LAGNEL, J. Direct amplification of length polymorphism (DALP), or how to get and characterize new genetic markers in many species. Nucleic Acids Research, v. 26, p. 1458-1465, 1998.

DEWOODY, J. A.; AVISE, J. C. Microsatellite variation in marine, freshwater and anadromous fishes compared with other animals. Journal of Fish Biology, v. 56, p. 461-473, 2000.

DIZON, A. E.; LOCKYER, C.; PERRIN, W. F.; DEMASTER, D. P.; SISSON. J. Rethinking the stock Concept: a phylogeographic approach. Conservation Biology, v. 6, p. 24-36, 1992.

EDWARDS, K. J.; BARKER, J. H. A.; DALY, A.; JONES, C.; KARP, A. Microsatellite libraries enriched for several microsatellite sequences in plants. Biotechniques, v. 20, p. 758-760, 1996.

EDWARDS, P.; HIEP, D.; ANH P.; MAIR, G. Traditional culture of indigenous common carp in rice fields in northern Vietnam: does it have a future in poverty reduction? World Aquaculture, v. 31, p. 34-40, 2000.

EKNATH, A.E. Genetic Improvement of Farmed Tilapia-GIFT Phase 1 Final Report, International Center for Living Aquatic Resources Management (ICLARM), Metro Manila, Philippines. 1992.

EKNATH, A. E.; TAYAMEN, M. M.; PALADA-DE-VERA, M. P.; DANTING, J. C.; REYES, R. A.; DIONISIO, E. E.; CAPILI, J. B.; BOLIVAR, H. L.; ABELLA, T. A.; CIRCA, A. V.; 
BETSEN, H. B.; GJERDE, B.; GJEDREM, T.; PULLIN, R. S. V. Genetic improvement of farmed tilapias: the growth performance of eight strains of Oreochromis niloticustested in different farm environments. Aquaculture, v. 111, p. 171-188, 1993.

EKNATH A.E.; ACOSTA, B. Genetic Improvement of Farmed Tilapia Project. Final Report (1988-1997). ICLARM, Manila, 1998.

EKNATH, A. E.; BENTSEN, H. B.; PONZONI, R. W.; RYE, M.; NGUYENM N. H.; THODESEN, J.; GJERDE, B. Genetic improvement of farmed tilapias: Composition and genetic parameters of a synthetic base population of Oreochromis niloticusfor selective breeding. Aquaculture, v. 273, p. 1-14, 2007.

EKNATH, A. E.; HULATA, G. Use and exchange of genetic resources of nile tilapia (Orecohromis niloticus). Reviews in Aquaculture, v. 1, p. 197-213, 2009.

EXCOFFIER, L.; SMOUSE, P. E.; QUATTRO, J. M. Analysis of molecular variance inferred from metric distances among DNA haplotypes: application to human mitochondrial dna restriction data. Genetics, v. 131, p. 479-491, 1992.

EXCOFFIER, L. Analysis of population subdivision. In: BALDING, D.J.; M. BISHOP, M.;CANNINGS,C. (eds). Handbook of Statistical Genetics. John Wiley \& Sons, Chichester, UK, 2001. p. 271-324.

EXCOFFIER, L.; LAVAL, G.; SCHNEIDER, S. Arlequin ver. 3.0: An integrated software package for population genetics data analysis. Evolutionary Bioinformatics Online, v. 1, p. 47-50, 2005.

EXCOFFIER, L.; LISCHER, H. E. L. Arlequin suite ver 3.5: A new series of programs to perform population genetics analyses under Linux and Windows. Molecular Ecology Resources, v. 10, p. 564-567, 2010.

FAO. Report of the first meeting of the FAO ad hoc working party on genetic selection and conservation of genetic resources of fish, Rome, 7-10 December, 1971. FAO Fisheries Report 119, 1972. 9 p.

FAO. Pilot Study on conservation of animal genetic resources. A report of a cooperative project of the United Nations Environmental Programme (Project No. 0604-73/002). FAO, Rome, $1975.60 \mathrm{p}$.

FAO/UNEP. Conservation of the genetic resources of fish: problems and recommendations.

Report of the expert consultation on the genetic resources of fish. Rome, 9-13 June 1980. FAP Fisheries Technical Papers 217, 1981.43 pp.

FAO. Plant genetic resources: their conservation in situ for human use. Prepared in collaboration with the United Nations Educational, Scientific and Cultural Organization (UNESCO), UNEP and IUCN. Rome, 1989. 
FAO. Report of the international technical conference on plant genetic resources. ITCPGR/96/REP, Leipzig, Germany, FAO, 1996. 43 p.

FAO-COPESCAL. Inform del taller regional sobre el manejo de las pesquerías de bagres migratorios del Amazonas (Iquitos - Perú). Informe de campo F-5: Comisión de pesca continental para América Latina. FAO. Roma, 2000. 103 pp.

FAO. Fisheries and Aquaculture topics, Introduction of species. Topics Fact Sheets. In: Devin Bartley, D., FAO Fisheries and Aquaculture Department [online]. Rome. 2005-2012. Disponível em <http://www.fao.org/fishery/topic/13532/en>. Acesso em: 23 out 2012.

FAO. The State of the World's Animal Genetic Resources for Food and Agriculture, edited by Barbara Rischkowsky \& Dafydd Pilling. Rome. 2007. 511 p.

FAO. The Second Report on the State of the World's Plant Genetic Resources for Food and Agriculture. Food Agriculture Organization, Rome, 2010. 307 p.

FAO. Code of Conduct for Responsible Fisheries. FAO, Rome, 2011a.91 p.

FAO. Molecular genetic characterization of animal genetic resources. FAO Animal Production and Health Guidelines. No. 9, Rome, 2011b. 85 p.

FAO. Conservation of Plant Genetic Resources for Food and Agriculture. Disponível em: http://www.fao.org/agriculture/crops/core-themes/theme/seeds-pgr/conservation/en/. Acesso em: 20 abr. 2013.

FAO, WFP, IFAD. The State of Food Insecurity in the World 2012. Economic growth is necessary but not sufficient to accelerate reduction of hunger and malnutrition. FAO, Rome 2012. 61 p.

FAO/SOFIA, 2012. The state of world fisheries and aquaculture (SOFIA), FAO, Rome, 209 p.

FARIAS, I. P.; HRBEK, T.; BRINKMANN, H.; SAMPAIO, I.; MEYER, A.; Characterization and isolation of DNA microsatellite primers for Arapaima gigas, an economically important but severely over-exploited fish species of the Amazon basin. Molecular Ecology Notes, v. 3, p. 128-130, 2003.

FARIAS, I. P.; TORRICO, J. P.; GARCÍA-DÁVILA, C.; SANTOS, M.C.F.; HRBEK, T.; RENNO, J-F. Are rapids a barrier for floodplain fishes of the Amazon basin? A demographic study of the keystone floodplain species Colossoma macropomum (Teleostei: Characiformes). Molecular Phylogenetics and Evolution, v. 56, p. 1129-1135, 2010.

FELSENSTEIN, J. The theoretical population genetics of variable selection and migration. Annual Review of Genetics, v. 10, p. 253-280, 1976. 
FÉRAL, J-P. How useful are the genetic markers in attempts to understand and manage marine biodiversity? Journal of Experimental Marine Biology and Ecology, v. 268, p. 121-145, 2002.

FERGUSON, A. Biochemical systematic and evolution. Glasgow, Backie, 1980. 194 p.

FERGUSON, A.; TAGGART, J. B.; PRODOHL, P. A.; MCMEEL, O.; THOMPSON, C.; STONE, C.; MCGINNITY, P.; HYNES, R. A. The application of molecular markers to the study and conservation of fish populations, with special reference to Salmon. Journal of Fish Biology, v. 47 (Suppl. A), p. 103-126, 1995.

FERGUSON, M. M.; DANZMANN, R. G. Role of genetic markers in fisheries and aquaculture: useful tools or stamp collecting? Canadian Journal of Fisheries and Aquatic Science, v. 55, p. 1533-1563, 1998.

FERRARIS-JR, C. J. Arapaimatidae (Bonytongues). p.31. In: REIS, R.E.; KULLANDER, S.O.; FERRARIS-JR., C. J. (eds.). Checklist of the Freshwater Fishes of South and Central America. Porto Alegre: EDIPUCRS, Brasil. 2003.

FERRIS, S. D.; BERG, W. J. The utility of mitochondrial DNA in fish genetics and fishery management. In: RYMAN, N.; UT'TER, F. (eds.). Population genetics and fishery management.Univ. Wash. Press, Seattle, p. 277-300. 1987.

FERREIRA, M.E.; GRATTAPAGLIA, D. Introdução ao uso de marcadores moleculares em análise genética. 3 ed. Brasília: Embrapa-Cernagen, 1998. 220p.

FINGER, A.; KLANK, C. Molecular Methods: Blessing or Curse?. In: Habel,J. C.; Assmann,T. (eds.), Relict Species: Phylogeography and Conservation Biology, Springer-Verlag Berlin Heidelberg, pp. 309-320. 2010.

FISCHER D.; BACHMANN K. Microsatellite enrichment in organisms with large genomes (Alium cepa L.). Biotechniques, v. 24, p. 796-802, 1998.

FLAVELL, A. J.; KNOX, M.; PEARCE, S. R.; ELLIS, T. H. N. Retrotransposon based insertion polymorphisms (RBIP) for high throughput marker analysis. Plant Journal, v. 16, p. 643665, 1998.

FORESTI, F. A brief history of fish genetics in Brazil. Genetics and Molecular Biology, v. 31(suppl 1), p. 385-388, 2008.

FORMIGA-AQUINO, K. Variabilidade genética da piramutaba - Brachyplatystoma vaillantii (Velenciennes, 1840) (Siluriformes-Pimelodidae) no sistema EstuárioAmazonas-Solimões. 2004. 73 f. Dissertação de Mestrado, CPBA, INPA/UA, Manaus, 2004. 
FRANKEL, O. H.; BENNETT, E. (eds.). Genetic resources in plants-their exploration and conservation. International Biological Programme Handbook 11. Blackwell, Oxford, England, 1970.

FRANKEL, O. H.; HAWKES, J. G. (eds.). Crop genetic resources for today and tomorrow. Cambridge, Univ. Press, Cambridge, England, 1975.

FROESE, R.; PAULY, D. (eds). FishBase. World Wide Web electronic publication. 2013. Disponível em: <www.fishbase.org> 2013, version (04/2013). Acesso em: 25 abr 2013.

FROESE, R.; PAULY, D. (eds.). Species of Hypostomus in FishBase. Disponível em: $<<$ http://www.fishbase.org/Nomenclature/ValidNameList.php?syng=Hypostomus\&syns= \&vtitle $=$ Scientific + Names + where + Genus + Equals $+\% 3 \mathrm{Ci} \% 3 \mathrm{EHypostomus} \% 3 \mathrm{C} \% 2 \mathrm{Fi} \% 3 \mathrm{E}$ \&crit2=CONTAINS\&crit1=EQUAL>2013, version (04/2013). Acesso em: 25 abr 2013.

FUJINO, K. Skipjack tuna subpopulation identified by genetic characteristics in the western Pacific. In: MARR, J.C. (ed.). The Kuroshio: A symposium on the Japan Current. EastWest Center Press, Honolulu, 1970. p. 385-393.

GARCEZ, R.; CALCAGNOTTO, D.; ALMEIDA-TOLEDO, L. F. Population structure of the migratory fish Procbilodus lineatus(Characiformes) from rio Grande basin (Brazil), an area fragmented by dams. Aquatic conservation: marine and freshwater ecosystems, v. 21, p. 268-275, 2011.

GASTON, K. J. What is biodiversity? In: GASTON, K.J. (ed.). Biodiversity: a biology of numbers and difference. Oxford, U.K.: Blackwell Science Ltd., 1996. p. 1-9.

GAUD, W. S. The Green Revolution: Accomplishments and Apprehensions. Ag Bio World. 1968. Disponível em: http://www.agbioworld.org/biotech-info/topics/borlaug/borlauggreen.html. Acesso em: 8 agos 20112.

GERSTNER, C. L.; ORTEGA, H.; SANCHEZ, H.; GRAHAM, D.L. Effects of the freshwater aquarium trade on wild fish populations in differentially-fished areas of the Peruvian Amazon. Journal of Fish Biology, v. 68, p. 862-875, 2006.

GÉRY, J. Characoids of the world. T.E.H. Publications, New Jersey. 1977. 672 p.

GJEDREM, T. Breeding plans for rainbow trout. Aquaculture, v. 100, p. 73-83,1992.

GOLDSTEIN, D. B.; LINARES, A. R.; CAVALLI-SFORZA, L. L.; FELDMAN, M. W. An evaluation of genetic distances for use with microsatellite loci. Genetics, v. 139, p. 463-471, 1995.

GOMES, P. C.; RIBEIRO, R. P.; LOPERA-BARRERO, N. M.; POVH, J. A.; VARGAS, L.; SIROL, R. N. Diversidade genética de três estoques de piapara (Leporinus elongatus), utilizando RAPD. Acta Scientiarum Animal Sciences, v. 30, p. 241-247, 2008. 
GOMES, P. C.; RIBEIRO, R. P.; SIROL, R. N.; LOPERA-BARRERO, N. M.; MOREIRA, H. L. M.; POVH, J. A.; MANGOLIN, C. A.; VARGAS, L.; JACOMETO, C. B.; STREIT-JR., D. S. Diversidade genética de dourado utilizado em programas de repovoamento no rio Paranapanema.Pesquisa Agropecuária Brasileira, v. 46, p. 167-173, 2011.

GONDIM, S. G. C. A.; RESENDE, L. V.; BRONDANI, R. P. V.; COLLEVATTI, R.G.; SILVA-JÚNIOR, N. J.; PEREIRA, R. R.; TELLES, M. P. C., Development of microsatellite markers for Hoplias malabaricus (Erythrinidae). Genetics and Molecular Research, v. 9, p. 1513-1517, 2010.

GONZÁLEZ-VILLASEÑOR, L. I.; BURKHOFF, A. M.; CORCES, V.; POWERS, D. A. Characterization of cloned mitochondrial DNA from the Teleost Fundulus heteroclitus and its usefulness as an interspecies hybridization probe. Canadian Journal of Fisheries and Aquatic Sciences, v. 43, p. 1866-1872, 1986.

GRANT, W. S.; BOWEN, B. M. Shallow population histories in deep evolutionary lineages of marine fishes: insights from the sardines and anchovies and lessons for conservation. Journal of Heredity, v. 89, p. 415-426, 1998.

GRODZIEKER T.; WILLIAMS, J.; SHARP, P.; SAMBROOK, J. Physical mapping of temperature sensitive mutations of adenovirus. Cold Spring Harbor Symposia on Quantitative Biology, v. 39, p. 439-446, 1974.

GROSS, M.R. One species with two biologies: Atlantic salmon (Salmon salar) in the wild and in aquaculture. Canadian Journal of Aquatic and Fisheries Science, v. 55(S1), p. 131-144, 1998.

GULLAND, J.A. 1969. Manual of Methods for Fish Stock Assessment - Part 1. Fish Population Analysis. FAO Manuals in Fisheries Science No. 4, 1969. 154 p.

GYLLENSTEN, U. The genetic structure of fish: differences in the intraspecific distribution of biochemical genetic variation between marine, anadromous, and freshwater species. Journal of Fish Biology, v. 26, p. 691-699, 1985.

HAFFER, J. General aspects of the refuge theory. In: PRANCE, G. T. (ed.), Biological Diversification in the Tropics. New York Columbia University Press, 1982. p. 6-26.

HALE, M. L.; BURG, T. M.; STEEVES, T. E. Sampling for microsatellite-based population genetic studies: 25 to 30 individuals per population is enough to accurately estimate allele frequencies. PloS One, v. 7, p. e45170, 2012.

HALLERMAN E. M.; BECKMANN J. S. DNA-Level polymorphism as a tool in fisheries science. Canadian Journal of Fisheries and aquatic Sciences, v. 45, p. 1075-1087, 1988. 
HAMILTON M.; PINCHUS E.; DI FIORE A.; FLEISHER R. Universal linker and ligation procedures for construction of genomic DNA libraries enriched for microsatellites. Biotechniques, v. 27, p. 500-507, 1999.

HAMOY, I. G. SANTOS, E. J. M.; SANTOS, S. E. B. Rapid and inexpensive analysis of genetic variability in Arapaima gigas by PCR multiplex panel of eight microsatellites. Genetics and Molecular Research, v. 7, p. 29-32, 2008.

HAMOY, I. G.; CIDADE, F. W.; BARBOSA, M. S.; GONÇALVES, E. C.; SANTOS, S. Isolation and characterization of tri and tetranucleotide microsatellite markers for the tambaqui (Colossoma macropomum, Serrasalmidae, Characiformes). Conservation Genetic Resources, v. 3, p. 33-36, 2011.

HAMOY, I. G.; SANTOS, S. Multiplex PCR panel of microsatellite markers for the tambaqui,Colossoma macropomum, developed as a tool for use in conservation and broodstock management. Genetics and Molecular Research, v. 11, p. 141-146, 2012.

HARDY, G.H. Mendelian proportions in a mixed population. Science, v. 28, p. 49-50. 1908

HARLAN, J. R. Agricultural origins: Centers and Noncenters. Science, v. 174, p. 468-474, 1971.

HARLAN, J. R. The plants and animals that nourish man. Scientific American, v. 235, p. 89-97, 1976.

HARLAN, J. R.. Crops and man. American Society of Agronomy, Inc and Crop Science Society of America, Inc, 2a. ed., Madison, USA, 1992. 283 p.

HARRIS, H. Enzyme polymorphism in man. Proceedings of the Royal Society B: Biological Sciences, v. 164, p. 298-310, 1966.

HARTL, D.L.; CLARK A.G. Princípios de genética de populações. Artmed, Porto Alegre, 2010. 659 p.

HASHIMOTO, D. T.; PRADO, F. D.; SENHORINI, J. A.; FORESTI, F.; PORTO-FORESTI, F. Detection of post-F1 catfish hybrids in broodstock using molecular markers: approaches for genetic management in aquaculture. Aquaculture Research, DOI: 10.1111/j.13652109.2012.03092.x., 2012.

HASHIMOTO, D. T.; PORTO-FORESTI, F.; SENHORINI, J. A.; FORESTI, F.; Interspecific fish hybrids in Brazil: management of genetic resources for sustainable use. Reviews in Aquaculture, v.4, p. 108-118, 2012.

HATANAKA, T., HENRIQUE-SILVA, F., GALETTI-JR., P. M., A polymorphic, telomericlike sequence microsatellite in the Neotropical fish Prochilodus. Cytogenetic Genome Research, v. 98, p. 308-310, 2002. 
HATANAKA, T.; MANOEL GALETTI-JR.; P. M. RAPD markers indicate the occurrence of structured populations in a migratory freshwater fish species. Genetics and Molecular Biology, v. 26, p.19-25, 2003.

HATANAKA, T.; HENRIQUE-SILVA, F.; GALETTI-JR., P.M. Population substructuring in a migratory freshwater fish Prochilodus argenteus(Characiformes, Prochilodontidae) from the São Francisco River. Genetica, v. 126, p.153-159, 2006.

HAUSDORF, B.; WILKENS, H.; STRECKER, U. Population genetic patterns revealed by microsatellite data challenge the mitochondrial DNA based taxonomy of Astyanaxin Mexico (Characidae, Teleostei). Molecular Phylogenetics and Evolution, v. 60, p. 89-97, 2011.

HAYASHI, J.-I.; TAGASHIRA, Y.; YOSHIDA, M. C. Absence of extensive recombination between inter- and intraspecies mitochondrial DNA in mammalian cells. Experimental Cell Research, v.160, p. 387-395, 1985.

HE, C.; CHEN, L.; SIMMONS, M.; LI, P.; KIM, S.; LIU, Z.J. Putative SNP discovery in interspecific hybrids of catfish by comparative EST analysis. Animal Genetics, v. 34, p. 445-448, 2003.

HEATH, D. D.; IWAMA, G. K.; DEVLIN, R. H. PCR primed with VNTR core sequences yields species-specific patterns and hypervariable probes. Nucleic Acids Research, v. 21, p. 5782-5785, 1993.

HEDRICK, P. W. Perspective: highly variable loci and their interpretation in evolution and conservation. Evolution, v. 53, p. 313-318, 1999.

HEDRICK, P. W. A standardized genetic differentiation measure. Evolution, v. 59, p. $1633-$ 1638, 2005.

HELFMAN, G.; COLLETTE, B. B.; FACEY, D. E.; BOWEN, B. W. The Diversity of Fishes: Biology, Evolution, and Ecology. Wiley-Blackwell, Oxford, 2009. p. 355-390.

HELLER R.; SIEGISMUND, H. Relationship between three measures of genetic differentiation $\mathrm{G}_{S T}, \mathrm{D}_{E S T}$, and $\mathrm{G}_{S T}$ : how wrong have we been? Molecular Ecology, v.18, p. 2080-2083, 2009.

HELMER, D.; GOURICHON, L.; MONCHOT, H.; PETERS, J.M.; SEGUI, M.S. Identifying early domestic cattle from Pre-Pottery Neolithic sites on the Middle Euphrates using sexual dimorphism. In: VIGNE, J. D.; PETERS, J.; HELMER, D., (eds.), First Steps of Animal Domestication, New Archaeozoological Approaches, Oxbow Books, Oxford, 2005. p. 86-95.

HENDRY, A. P.; DAY, T.; TAYLOR, E.B. Population mixing and the adaptive divergence of quantitative traits in discrete populations: a theoretical framework for empirical tests. Evolution, v. 55, p. 459-466, 2001. 
HENSLEY, D. A.; MOODY, D.P. Occurrence and possible establishment of Hoplias malabaricus(Characoidei: Erythrinidae) in Florida. Florida Scientist, v. 38, p. 122-128, 1975.

HIGGS, E.; JARMAN, M. R. The origins of agriculture: A reconsideration. Antiquity v. 43, p. 31-41, 1969.

HILSDORF, A. W. S. Diversidade genética do DNA mitocondrial em populações cultivadas e selvagens da Pirapitinga do sul, Brycon opalinus (Cuvier, 1819) (Chraraciforme, Characidae), na bacia do Paraíba do Sul. 1999. 150 f. Tese de Doutoramento, Instituto de Biologia, Universidade Estadual de Campinas.

HILSDORF, A. W. S.; KRIEGER, J. E. Characterization of six rat strains (Rattus norvegicus) by mitochondrial DNA restriction fragment length polymorphism (RFLP). Brazilian Journal of Medical and Biological Research, v. 32, p. 267-273, 1999.

HILSDORF, A. W. S.; CANEPPELE, D.; KRIEGER, J. E. Muscle biopsy technique for electrophoresis analysis of fish from the genus Brycon. Genetics and Molecular Biology, v. 22, p. 547-550, 1999.

HILSDORF, A. W. S.; ESPIN, A. M. L. A.; KRIEGER, M. H.; KRIEGER, J. E. Mitochondrial DNA diversity in wild and captivity population of Brycon opalinus (Cuvier, 1819) (Characiforme, Characidae, Bryconiae), in the Paraíba do Sul Basin, Brazil. Aquaculture, v. 214, p. $81-91,2002$.

HILSDORF, A. W. S.; MARQUES, D. K. S.; RESENDE, E. K. Genética e Conservação de Estoques Pesqueiros de Águas Continentais no Brasil: Situação Atual e Perspectivas. Embrapa Pantanal, Documentos 82, 2006. 44 p.

HOFFMAN, J. I., NICHOLS, H. J. A Novel Approach for Mining Polymorphic Microsatellite Markers In Silico. PLoS One, v. 6, p. e23283, 2011.

HOLTSMARK, M.; KLEMETSDAL, G.; SONESSON, A. K.; WOOLLIAMS, J. A. Establishing a base population for a breeding program in aquaculture, from multiple subpopulations, differentiated by genetic drift: II. Sensitivity to assumptions on the additive genetic relationships of base animals. Aquaculture, v. 274, p. 241-246, 2008.

HOSSEINPOOR, A. R.; HARPER, S.; LEE, J. H.; LYNCH, J.; MATHERS, C.; ABOU-ZAHR, C.International shortfall inequality in life expectancy in women and in men, 1950-2010. Bulletin of the World Health Organization, v. 90, p. 588-594, 2012.

HRBEK, T.; FARIAS, I. P.; CROSSA, M.; SAMPAIO, I.; PORTO, J.I.R.; AXEL MEYER, A. Population genetic analysis of Arapaima gigas, one of the largest freshwater fishes of the Amazon basin: implications for its conservation. Animal Conservation, v. 8, p. 297-308, 2005. 
HRBEK, T.; CROSSA, M.; FARIAS, I. P. Conservation strategies for Arapaima gigas(Schinz, 1822) and the Amazonian várzea ecosystem. Brazilian Journal of Biology, v. 67(4, Suppl.), p. 909-917, 2007.

HU, J.; VICK, B. A. Target region amplification polymorphism: a novel marker technique for plant genotyping. Plant Molecular Biology Reporter, v. 21, p. 289-294, 2003.

HUBBY, J. L.; LEWONTIN, R.C. A molecular approach to the study of genic heterozygosity in natural populations. I. The number of alleles at different loci in Drosophila pseudoobscura. Genetics, v. 54, p. 203-215, 1966.

HUERGO, G. M.; FILGUEIRAS-SOUZA, R. J.; BATISTA, J. S.; FORMIGA-AQUINO, K.; ALVES-GOMES, J. A. Molecular genetics as a tool for fisheries management in the Brazilian Amazon: Piraíba (Brachyplatystoma filamentosum and Brachyplatystoma capapretum) (Siluriformes: Pimelodidae) in white-water rivers. Pan-American Journal of Aquatic Sciences, v.6, p. 280-289, 2011.

HUGHES, J. B., DAILY, G. C., EHRLICH, P. R. Population diversity: its extent and extinction. Science, v. 278, p. 689-692, 1997.

HUNTER, R., MARKERT, C. Histochemical demonstration of enzymes separated by zone electrophoresis in starch gels. Science, v. 125, p. 1294, 1957.

HURTADO-ALARCÓN， J. C.; MANCERA-RODRÍGUEZ， N. J.; SALDAMANDOBENJUMEA, C. I. Variabilidad genética de Brycon henni (Characiformes: Characidae) en la cuenca media de los ríos Nare y Guatapé, sistema Río Magdalena, Colombia. Revista de Biologia Tropical, v. 59, p. 269-282, 2011.

IBPGR (comp.) Elsevier's dictionary of plant genetic resources. Elsevier Science Publishers B.V., Holanda. 1991. 187 p.

IERVOLINO, F.; RESENDE, E. K.; HILSDORF, A. W. S. 2010. The lack of genetic differentiation of pacu (Piaractus mesopotamicus) populations in the Upper-Paraguay Basin revealed by the mitochondrial DNA D-loop region: Implications for fishery management. Fisheries Research, v. 101, p. 27-31, 2010.

IHSSEN, P.E.; BOOJE, H. E.; CASSELMAN, J. M.; MCGLADE, J. M.; PAYNE,N. R.; UTTER,D F. M. Stock identification: materials and methods. Canadian Journal of Fisheries and Aquatic Sciences, v. 38, p. 1838-1855. 1981.

INOUE, L.A.K.A.; BOIJINK, C.L.Manaus a capital do tambaqui. 2011. Disponível em: <http: // www.infobibos.com/Artigos/2011_1/tambaqui/index.htm>. Acesso em 17 abr 2013. 
IWAMA, G.K.; MCGEER, J.C.; BERNIER, N.J. The effects of stock and rearing history on the stress response in juvenile coho salmon (Oncorbynchus kisutch). ICES Journal of Marine Science Symposium; v. 194, p. 67-83, 1992.

JAARSVELD, A. S.; MIDGLEY, G. F.; MILES, L. M.; ORTEGA-HUERTA, M. A.; TOWNSEND P. A.; PHILLIPS, O. L.; WILLIAMS, S. E. Extinction risk from climate change. Nature, v. 427, p. 145-148, 2004.

JACOMETO, C. B.; LOPERA-BARRERO, N. M.; RODRIGUEZ-RODRIGUEZ, M. D. P.; GOMES, P. C.; POVH, J. A.; STREIT-JR., D. P.; VARGAS, L., RESENDE, E. K.; RIBEIRO, R. P. Variabilidade genética em tambaquis (Teleostei: Characidae) de diferentes regiões do Brasil. Pesquisa Agropecuária Brasileira, v. 45, p. 481-487, 2010.

JARAMILLO, S.; BAENA, M. Material de apoyo a la capacitación en conservación exsitude los recursos fitogenéticos. Instituto Internacional de Recursos Fitogenéticos, Cali Colombia. 2000. 209 p.

JARNE, P.; LAGODA, P. J. L. Microsatellites, form molecules to populations and back. Trends in Evolution and Ecology, v. 11, p. 424-429, 1996.

JEFFREYS, A. J.; WILSON, V.; THEIN, S. L. Hypervariable "minisatellite" regions in human DNA. Nature, v.314, p. 67-73, 1985a.

JEFFREYS, A. J.; WILSON, V.; THEIN, S. L. Individual-specific "fingerprints" of human DNA. Nature, v. 316, p. 76-79, 1985b.

JERRY, D. R.; PURVIS, I. W.; PIPER, L. R. Genetic differences in growth among wild populations of the yabby, Cherax destructor (Clark). Aquaculture Research, v. 33, p. 917-923, 2002.

JOHNSON, F.; KANAPI, C.; RICHARDSON, R.; WHEELER, M.; STONE W. An analysis of polymorphisms among isozyme loci in dark and light Drosophila ananassaestrains from American and Western Samoa. Proceedings of the National Academy of SciencesUSA, v.56, p. 119-125, 1966.

JOST, L., $G_{S T}$ and its relatives do not measure differentiation. Molecular Ecology, v. 17, p. 4015-4026, 2008.

JOST, L. Reply: D vs $G_{S T}$ : response to Heller and Siegismund (2009) and Ryman and Leimar (2009). Molecular Ecology, v. 18, p. 2088-2091, 2009.

JUNK, W. J., MELLO J. A. S. N. Impactos ecológicos das represas hidrelétricas na bacia amazônica brasileira. Estudos Avançados, v. 4, p. 126-143, 1990.

JUNK, W. J.; CUNHA, C. N. Pantanal: a large South American wetland at a crossroads. Ecological Engineering, v. 24, p. 391-401, 2005. 
KALENDAR, R.; GROB, T.; REGINA, M.; SUONIEMI, A.; SCHULMAN, A. IRAP and REMAP: two new retrotransposon-based DNA fingerprinting techniques. Theoretical and Applied Genetics, v.98, p. 704-711, 1999.

KALINOWSKI, S. T. How many alleles per locus should be used to estimate genetic distances? Heredity, v. 88, p. 62-65, 2002.

KIMURA, M. "Stepping Stone" model of population. Annual Report National Institute of Genetics-Japan, v. 3, p. 62-63, 1953.

KIMURA, M.; WEISS, W. H., The stepping stone model of genetic structure and the decrease of genetic correlation with distance. Genetics, v. 49, p.561-576, 1964.

KIMURA, M., Evolutionary rate at the molecular level. Nature, v. 217, p. 624-626, 1968.

KOCHER, T. D.; THOMAS, W. R.; MEYER, A; EDWARDS, S. V.; PÄÄBO, S.; VILLABANCA, F. X.; WILSON, A. C. Dynamics of mitochondrial DNA evolution in animals. Proceedings of the National Academy of Sciences of the United States of America,v. 86, p. 6196-6200, 1989.

KOEHN, R. K.; PEREZ, J. E.; MERRITT, R. B. Esterase enzyme function and genetical structure of populations of the freshwater fish, Notropis stramineus, American Naturalist, v.105, p. 51-69, 1971.

KOH, T. L.; KHOO, G.; FAN, L. Q.; PHANG, V. P. E. Genetic diversity among wild forms and cultivated varieties of Discus Symphysodon spp.as revealed by Random Amplified Polymorphic DNA - RAPDfingerprinting. Aquaculture, v. 173, p. 485-497, 1999.

KOTTELAT, M.; WHITTEN, T. Freshwater biodiversity in Asia, with special reference to fish. World Bank Technical Paper 343, 1996. 59 p.

KUMAR, N. S.; GURUSUBRAMANIAN, G. Random amplified polymorphic DNA (RAPD) markers and its applications. Science Vision, v.11, p. 116-124, 2011.

LANSMAN, R.A.; SHADE, R. O.; SHAPIRA, J. F.; AVISE, J. C. The use of restriction endonucleases to measure mitochondrial DNA sequence relatedness in natural populations. III. Techniques and potential applications. Journal of Molecular Evolution, v.17, p. 21426, 1981.

LARSEN, P. F.; NIELSEN, E. E.; MEIER, K.; OLSVIK, P. A.; HANSEN, M.M.; LOESCHCKE, V. Differences in salinity tolerance and gene expression between two populations of atlantic cod (Gadus morbua) in response to salinity stress. Biochemical Genetics, v. 50, p. 454-466, 2012.

LEE, W. J.; CONROY, J.; HOWELL, W. H.; KOCHER, T. D. Structure and evolution of teleost mitochondrial control regions. Journal of Molecular Evolution, v.41, p. 54-66, 1995. 
LEE-JENKINS, S. S. Y.; DENSMORE, A. M.; GODIN, J-G. J.; SMITH, M. L. Polymorphic microsatellite loci optimised for studies on the convict cichlid fish (Amatitlania siquia). Environmental Biology of Fishes, v. 92, p. 261-266, 2011.

LEITÃO, M. A.B. Estudo comparativo da estrutura genética de populações naturais e artificiais de tambaqui Colossoma macropomum (Cuvier, 1818): sistemas isozímicos. 1998. 75 f. Dissertação de Mestrado, Manaus: INPA-FUA, 1998.

LENORMAND, T. Gene flow and the limits to natural selection. Trends in Ecology and Evolution, v. 17, p. 183-189, 2002.

LENSTRA, J. A.; GROENEVELD, L. F.; EDING, H.; KANTANEN, J.; WILLIAMS, J. L.; TABERLET, P.; NICOLAZZI, E. L.; SÖLKNER, J.; SIMIANER, H.; CIANI, E.; GARCIA, J. F.; BRUFORD, M. W.; AJMONE-MARSAN, P.; WEIGEND, S. Molecular tools and analytical approaches for the characterization of farm animal genetic diversity. Animal Genetics, v. 43, p. 483-502, 2012.

LEUZZI, M. S. P.; ALMEIDA, F. S.; ORSI, M. L.; SODRÉ, L. M. K. Analysis by RAPD of the genetic structure of Astyanax altiparanae (Pisces, Characiformes) in reservoirs on the Paranapanema River, Brazil. Genetics and Molecular Biology, v. 27, p. 355-362, 2004.

LÉVÊQUE, C.; OBERDORFF, T.; PAUGY, D.; STIASSNY, M. L. J.; TEDESCO, P. A. Global diversity of fish (Pisces) in freshwater. Hydrobiologia, v. 595, p. 545-567, 2008.

LEWONTIN, R. C. The genetic basis of evolutionary change. New York, Columbia University Press. 1974. 346 p.

LEWONTIN, R.C. Twenty-five years ago in GENETICS: electrophoresis in the development of evolutionary genetics: milestone of millstone? Genetics, v. 128, p. 657-662, 1991.

LI, G.; QUIROS, C. F. Sequence-related amplified polymorphism (SRAP), a new marker system based on a simple PCR reaction: its application to mapping and gene tagging in Brassica. Theoretical and Applied Genetics, v.103, p. 455-546, 2001.

LIMA, M.P.; CAMPOS, T.; SOUSA, A. C. B.; SOUZA, A. P.; ALMEIDA-VAL, V. M. F. Isolation and characterization of microsatellite markers for Cichla monoculus(Agassiz, 1831), an important freshwater fish in the Amazon. Conservation Genetic Resources, v. 2, p. 215218, 2010.

LIMA-JR., S. E.; CARDONE, I. B.; GOITEIN, R. Fish assemblage structure and aquatic pollution in a Brazilian stream: Some limitations of diversity indices and models for environmental impact studies. Ecology of Freshwater Fish, v. 15, p. 284-290, 2006.

LIMEIRA, D. M.; RENESTO, E.; ZAWADZKI, C. H. Allozyme comparison of two populations of Rineloricaria (Siluriformes, Loricariidae) from the Ivaí River, upper Paraná River basin, Brazil. Genetics and Molecular Biology, v. 32, p. 431-435, 2009. 
LITT, M.; LUTY, J. A. A hypervariable microsatellite revealed by in vitro amplification of a dinucleotide repeat within the cardiac muscle actin gene. American Journal of Human Genetics, v. 44, p. 397-401, 1989.

LIVESTOCK IN DEVELOPMENT, 1999. Livestock in poverty-focused development. Livestock in Development, Crewkerne, UK. 1999. 94 p.

LIU, Z.J.; CORDES, J. F. DNA marker technologies and their applications in aquaculture genetics. Aquaculture, v. 238, p. 1 -37, 2004.

LOFTUS R. T.; MACHUGH D. E.; NGERE L. O.; BALAIN D. S.; BADI, A. M.; BRADLEY D.G., CUNNINGHAM E.P. Mitochondrial genetic variation in European, African and Indian cattle populations. Animal Genetics, v. 25, p. 265-71, 1994.

LOPERA-BARRERO, N. M.; RIBEIRO, R. P.; SIROL, R. N.; POVH, J.; GOMES, P.; STREIT-JR. D.; VARGAS, L.M. Caracterización genética de lotes de Brycon orbignyanus utilizados em programas de repoblamiento. Revista MVZ Córdoba, v. 13, p. 1110-1119, $2008 \mathrm{a}$

LOPERA-BARRERO, N. M.; RIBEIRO, R. P.; SIROL, R. N.; POVH, J. A.; GOMES, P. C.; VARGAS, L. M.; MANGOLIN, C. A. Caracterización genética de lotes de Brycon orbignyanus utilizados en programas de repoblamiento. Acta Biológica Colombiana, v. 13, p.107-118, 2008b.

LOPERA-BARRERO, N. M.; RIBEIRO, R. P.; POVH, J. A.; SIROL, R. N.; MANGOLIN, C. A. Avaliação genética de populações naturais e de estoques de um programa de repovoamento de pacu (Piaractus mesopotamicus) utilizando marcadores microssatélite. Arquivos Brasileiro de Medicina Veterinária e Zootecnia, v.62, p. 954-963, 2010.

LÓPEZ, L. Genetic variability and population structure of dorada (Brycon moorei sinuensis Dahl) in the Sinú River, Córdoba, Colombia. Lakes \& Reservoirs: Research and Management, v.11, p. 1-7, 2006.

LOPES, C.M.; ALMEIDA, F. S.; ORSI, M. L.; CASTRO, S. G.; SIROL, B. R. N.; SODRÉ, L. M. K. Fish passage ladders from Canoas Complex - Paranapanema River: evaluation of genetic structure maintenance of Salminus brasiliensis (Teleostei: Characiformes). Neotropical Ichthyology, v. 5, p.131-138, 2007.

LOVEJOY, N. R., ARAÚJO, M. L. G. Molecular systematics, biogeography and population structure of Neotropical freshwater needlefishes of the genus Potamorrhaphis. Molecular Ecology, v. 9, p. 259-268, 2000.

LOWE, D.R. Stromatolites 3,400 Myr old from the Archean of Western Australia. Nature, v. 284, p. 441-443, 1980. 
LOWE-MCCONNELL, R.H. The status of studies on South American freshwater food fishes. In: ZARET, T.M. (ed.), Evolutionary Ecology of Neotropical Freshwater Fishes. Boston, The Hague, 1984. p. 139-156.

LOWE-MCCONNELL, R H. Ecological studies in tropical fish communities. London, Cambridge University Press. 1987. 382 p.

LUNDBERG, J. G.; MARSHALL, L. G.; GUERRERO, J.; HORTON, B.; MALABARBA, M. C. S. L., WESSELINGH, F. 1998. The stage for Neotropical fish diversification: A history of tropical South American rivers. In: MALABARBA, L.R., REIS, R. E.; VARI, R. P.; LUCENA, Z. M.; LUCENA, C. A. S. (eds), Phylogeny and Classification of Neotropical Fishes, Porto Alegre, Edipucrs, 1998. p. 13-48.

LUNT, D. H.; HUTCHINSON, W. F.; CARVALHO, G. R. An efficient method for PCR-based isolation of microsatellite arrays (PIMA). Molecular Ecology, v. 8,p 891-894, 1999

LYNCH, M.; CREASE, T.J. The Analysis of Population Survey Data on DNA Sequence Variation. Molecular Biology and Evolution, v. 7, p. 377-394, 1990.

LYNCH, M.; MILLIGAN, B. G. Analysis of population structure with RAPD markers. Molecular Ecology, v. 3, p. 91-99, 1994.

MACHADO, C. E.; ABREU, H. C. F. Notas preliminares sobre a caça e a pesca no Estado de São Paulo. A pesca no Vale do Paraíba. Boletim Industrial Animal, v. 13, p. 145-160, 1952.

MACHADO, V.; SCHUlZ, U.; PALMA, L. P.; RODRIGUES, J. J. S. Mitochondrial DNA variation and genetic structure of the migratory freshwater fish dourado Salminus brasiliensis(Characidae). Acta Biologica Leopoldensia, v. 27, p. 107-113, 2005.

MACHADO, A. B. M.; DRUMMOND, G. M.; PAGLIA, A. P. (eds). Livro Vermelho da Fauna Brasileira Ameaçada de Extinção. Volume II. Brasília, DF: Ministério do Meio Ambiente, 2008. 906 p.

MANGINI, M. A.; COCHRANE, B. J.; PAUL, J. H. A readily accessible method for cloning fish mitochondrial DNA to generate homologous molecular probes. In: KULLANDER, S. O. FERNHOLM, B., (eds). Proceedings, V Congress of European Ichthyologists, Proceedings,Department of Vertebrate Zoology, Swedish Museum of Natural History, Stockholm, Sweden, 1985. p. 233-237.

MARIANTE, A. S.; EGITO, A. A. Animal genetic resources in Brazil: result of five centuries of natural selection. Theriogenology, v. 57, p. 23-235, 2002.

MARIANTE, A. S.; ALBUQUERQUE, M. S. M.; EGITO, A. A.; MCMANUS, C.; LOPES, M. A.; PAIVA, S. R. Present status of the conservation of livestock genetic resources in Brazil. Livestock Science, v. 120, p. 204-212, 2009. 
MARR, J. C. Contributions to the study of subpopulations of fishes. U.S. Fish and Wildlife Service, Washington, D.C. Special scientific report-fisheries 208. 1957. 129 p.

MARTIN, P. R.; MCKAY, J. K. Latitudinal variation in genetic divergence of populations and the potential for future speciation. Evolution, v.58, p. 938-945, 2004.

MARTINS, C.; WASKO, A. P.; OLIVEIRA, C.; FORESTI, F. Mitochondrial DNA variation in wild populations of Leporinus elongatus from the Paraná River basin. Genetics and Molecular Biology, v. 26, p. 33-38, 2003.

MATOSO, D. A.; ARTONI, R. F.; GALETTTI-JR., P. M. Genetic diversity of the small characid fish Astyanaxsp., and its significance for conservation. Hydrobiologia, v. 527, p. 223-225, 2004.

MATOSO, D. A.; MARTINS, C.; ARTONI, R. F.; GALETTI-JR., P.M. Preliminary Qualitative analysis on mtDNA in Astyanax fasciatus populations Cuvier, 1819 (Teleostei; Characidae) indicate population distinctiveness. Brazilian Archives of Biology and Technology, v. 53, p. 663-667, 2010.

MATSUMOTO, C. K.; HILSDORF, A. W. S. Microsatellite variation and population genetic structure of a Neotropical endangered Bryconinae species Brycon insignis Steindachner, 1877: implications for its conservation and sustainable management. Neotropical Ichthyology, v. 7, p. 395-402, 2009.

MEYER, A. Evolution of mitochondrial DNA in fishes. In: HOCHACHKA, P. W.; MOMMSEN, T. P. (eds.), Biochemistry and Molecular Biology of Fishes. Elsevier Science Publishers, New York, 1993. p. 1-38.

MEYER, A., Molecular phylogenetic studies of fish. In: BEAUMONT, A.R (ed.) Genetics and Evolution of Aquatic Organisms, Chapman \& Hall, London, 1994. p. 220-248.

METZKER, M. L. Emerging technologies in DNA sequencing. Genome Research, v. 15, p. 1767-1776, 2005.

MCHUGH, J. L. Vertebral number of young herring in southern British Columbia Journal of the FisheriesResearch Board of Canada, v. 5, p. 474-484, 1942.

MCNEELY, J. A.; MILLER, K. R.; RELD, W. V.; MITTERMEIER, R. A.; WERNER, T. B.Conserving the world's biological diversity. World Conservation Union, World Resources Institute, Conservation International, World Wildlife Fund-US, and the World Bank, Washington, DC., 1990. 193 p.

MITTON, J. B.; GRANT, M.C. Associations among protein heterozygosity, growth rate, and developmental homeostasis. Annual Review of Ecology and Systematics, v. 15, p. 479499, 1984. 
MOESER, A. A.; BERMINGHAM, E. Isolation and characterization of eight microsatellite loci for the Neotropical freshwater catfish Pimelodella chagresi (Teleostei: Pimelodidae). Molecular Ecology Notes, v. 5, p. 363-365, 2005.

MONTOYA-BURGOS, J. I. Historical biogeography of the catfish genus Hypostomus (Siluriformes: Loricariidae), with implications on the diversification of Neotropical ichthyofauna. Molecular Ecology, v. 12 p. 1855-1867, 2003.

MORALES, P; POULIN, I.V.E. Genetic structure in remnant populations of an endangered cyprinodontid fish, Orestias ascotanensis, endemic to the Ascotán salt pan of the Altiplano. Conservation Genetics, v. 12, p. 1639-1643, 2011.

MORELLI, K. A.; REVALDAVES, E.; OLIVEIRA, C.; FORESTI, F. Isolation and characterization of eight microsatellite loci in Leporinus macrocephalus (Characiformes: Anostomidae) and cross-species amplification. Molecular Ecology Notes, v. 7, p. 32-34, 2007.

MORELli, K. A., OLIVEIRA, C., PORTO-FORESTI, F., SENHORINI J.A., FORESTI, F. Population structure of Prochilodus lineatus(Characiformes, Prochilodontidae) in the MogiGuaçu river identified by molecular analysis. In: POMPEU, P S. H., SANTOS, H. A., ALVES, C. B. M. (eds), Proceedings of the international symposium on fish passages in South America, Lavras, UFLA, 2007. p. 7-10.

MORITZ, C. Applications of mitochondrial DNA analysis in conservation: a critical review. Molecular Ecology, v. 3, p. 401-411, 1994.

MOYER, G. R.; WINEMILlER, K. O.; MCPHEE, M. V.; TURNER, T. F. Historical demography, selection, and coalescence of mitochondrial and nuclear genes in Prochilodus species of northern South America. Evolution, v.59, p. 599-610, 2005.

MOYSÉS, C. B.; ALMEIDA-TOLEDO, L. F. Restriction fragment length polymorphisms of mitochondrial DNA among five freshwater fish species of the genus Astyanax (Pisces, Characidae). Genetics and Molecular Biology, v. 25, p. 401-407, 2002.

MOYSÉS, C. B.; MOCKFORD, S.; ALMEIDA-TOLEDO, L. F.; WRIGHT, J. M. Nine polymorphic microsatellite loci in the Neotropical electric eel Eigenmannia (Teleostei: Gymnotiformes). Molecular Ecology Notes, v. 5, p. 7-9, 2005

MPA, 2010. Ministério da Pesca e Aquicultura. Boletim estatístico da pesca e aquicultura: Brasil 2008-2009. 99 p. Disponível em: http://www.mpa.go v.br/mpa/seap/Jonathan/mpa3/docs/anu $\%$ E1 rio $\% 20 \mathrm{da} \% 20$ pesca $\% 20$ completo2.pdf. Acesso em: 20 dez. 2011. 
MPA,

2013.

Disponível

em:

<http://www.mpa.gov.br/index.php/aquiculturampa/informacoes/producao>. Acesso em: 15 abr 2012.

MUNÕZ-ROJAS, P.; QUEZADA-ROMEGIALLI, C.; VÉLIZ， D. Isolation and characterization of ten microsatellite loci in the catfish Trichomycterus areolatus (Siluriformes: Trichomycteridae), with cross-amplification in seven Trichomycterinae species. Conservation Genetic Resources, v. 4, p. 443-445, 2012.

NASCIMENTO, P. R. M., SANTOS, C. H. A., SOUSA, C. F. S., ClíMACO, G. T., PAULASILVA, M. N., ALMEIDA-VAL, V. M. F. Isolation and development microsatellite markers in the Pygocentrus nattereri(Kner, 1858) (Characiformes, Serrasalminae), an important freshwater fish in the Amazon. Conservation Genetic Resources, v. 4, p. 271-274, 2012.

NATER, A.; KRÜTZEN, M.; LINDHOLM, A. K. Development of polymorphic microsatellite markers for the livebearing fish Poecilia parae. Molecular Ecology Resources, v. 8, p. 857860,2008

NEI, M. Genetic distance between populations. American Naturalist, v.106, p. 283-292, 1972.

NEI, M. Analysis of gene diversity in subdivided populations. Proceedings of the National Academy of Sciences USA, v.70, p. 3321-3323, 1973.

NEI, M.Molecular Population Genetics and Evolution. North-Holland, New York. 1975. 290 p.

NEI, M. F-statistics and analysis of gene diversity in subdivided populations. Annals of Human Genetics, v.41, p. 225-233, 1977.

NEI, M.Estimation of average heterozygosity and genetic distance from a small number of individuals. Genetics, v. 89, p. 583-590, 1978.

NEI, M.; LI, W. H. Mathematical model for studying genetic variation in terms of restriction endonucleases. Proceedings of the National Academy of Sciences USA, v.76, p. 5269$5273,1979$.

NEI, M.; TAJIMA, F. DNA polymorphism detectable by restriction endonucleases. Genetics, v. 97, p.145-163, 1981.

NELSON, J. S. Fishes of the World. John-Willey \& Sons Inc., 4a. ed., Hoboken, New Jersey, 2006. $601 \mathrm{p}$.

NOACK, K.; WILSON, A. B.; MEYER, A. Broad taxonomic applicability of microsatellites developed for the highly polymorphic neotropical cichlid, Amphilophus citrinellum. Animal Genetics, v. 31, p. 151-152, 2000. 
NOGUEIRA, C.; BUCKUP, P.A.; MENEZES, N. A.; OYAKAWA, O. T.; KASECKER, T. P.; NETO, M. B. R.; SILVA, J. M. C. Restricted-Range Fishes and the Conservation of Brazilian Freshwaters. PLoS One, v. 5, p. e11390, 2010.

OECD. Organization for Economic Co-operation and Development. Glossary of Statistical Terms. 2013. Disponível em <http://stats.oecd.org/glossary/index.htm>. Acesso 13 jan 2013

O'CONNELL, M.; WRIGHT, J. M. Microsatellite DNA in fishes. Reviews in Fish Biology and Fisheries, v. 7, p. 331-363, 1997.

OKAZAKI, T. I. Avaliação da diversidade genética intra e interpopulacional da piraputanga (Brycon hilarii) na bacia do alto paraguai por meio de microssatélites para o seu manejo sustentado. 2009. 92 f. Dissertação de Mestrado, Universidade de Mogi das Cruzes, 2009.

OKUMUS, I.; ÇIFTCI, Y. Fish Population Genetics and Molecular Markers: II- Molecular Markers and Their Applications in Fisheries and Aquaculture. Turkish Journal of Fisheries and Aquatic Sciences, v. 3, p. 51-79, 2003.

OLIVATTI, A. M.; BONI, A. M.; SILVA-JÚNIOR, N. J.; RESENDE, L. V.; GOUVEIA, F. O.; TELLES, M. P. C. Heterologous amplification and characterization of microsatellite markers in the Neotropical fish Leporinus friderici. Genetics and Molecular Research, v. 10, p. $1403-$ $1408,2011$.

OLIVEIRA, A. V.; PRIOLI, A. J.; PRIOLI, S. M. A .P.; PAVANELLI, C. S.; JÚLIO-JR., H. F.; PANARARI. R. S. Diversity and genetic distance in populations of Steindachnerina in the upper Paraná river floodplain of Brazil. Genetica, v.115, p. 259-267, 2002.

O'REILLY, P.; WRIGHT, J. M. The evolving technology of DNA fingerprinting and its application to fisheries and aquaculture. Journal of Fish Biology, v. 47 (Suppl. A), p. 29-55, 1995.

ORITA, M.; IWAHANA, H., KANAZAWA, H., HAYASHI, K., SEKIYA, T. Detection of polymorphisms of human DNA by gel electrophoresis as single-strand conformation polymorphism. Proceedings of the National Academy of Sciences USA, v. 86, p. 2766$2770,1989$.

ORGEL, L. The origin of life on earth. Scientific American, v. 271, p. 81, 1994.

OYAKAWA, O.T. Family Erythrinidae. In: REIS, R.E.; KULLANDER, S.O.; FERRARIS JR., C.J., (ed.), Check List of the Freshwater Fishes of South America. Porto Alegre: Edipucrs, 2003. p. 238-240. 
PAIVA, S.; RENESTO, E.; ZAWADZKI, C. H. Genetic variability of Hypostomus(Teleostei, Loricariidae) from the Ribeirão Maringá, a stream of the upper Rio Paraná basin, Brazil. Genetics and Molecular Biology, v. 28, p. 370-375, 2005.

PAIVA, S. R., DERGAM, J. A.; MACHADO, F. Determining management units in southeastern Brazil: the case of Astyanax bimaculatus (Linnaeus, 1758) (Teleostei: Ostariophysi: Characidae). Hydrobiologia, v. 560, p. 393-404, 2006.

PAIVA, A. L. B.; KALAPOTHAKIS, E. Isolation and characterization of microsatellite loci in Pimelodus maculatus (Siluriformes: Pimelodidae). Molecular Ecology Resources, v. 8, p. 1078-1080, 2008.

PALUMBI, S.; MARTIN, A.; ROMANO, W.O.; STICE, L.; GRABOWSKI, G. The Simple Fool's Guide to PCR, version 2.0. Honolulu: University of Hawaii, 1991.

PAMPONET, V. C. C.; CARNEIRO, P. L. S.; AFFONSO, P. R. A. M.; MIRANDA, V. S.; SILVA-JR., J. C.; OLIVEIRA, C. G.; GAIOTTO, F.A. A multi-approach analysis of the geneticdiversity in populations of Astyanax aff. bimaculatus Linnaeus, 1758 (Teleostei: Characidae) from Northeastern Brazil. Neotropical Ichthyology, v. 6, p. 621-630, 2008.

PANARARI-ANTUNES, R. S.; PRIOLI, A. J.; PRIOLI, S. M. A. P.; GALDINO, A.S., JULIOJR., H. F.; PRIOLI, L. M.; Genetic Variability of Brycon orbignyanus (Valenciennes, 1850) (Characiformes: Characidae) in Cultivated and Natural Populations of the Upper Paraná River, and Implications for the Conservation of the Species. Brazilian Archives of Biology and Technology, v. 54, p. 839-848, 2011.

PARAN, I.; MICHELMORE, R. W. Development of reliable PCR-based markers linked to downy mildew resistance genes in lettuce. Theoretical and Applied Genetics, v. 85, p. 985-999, 1993.

PARK, L. K.; MORAN, P. Developments in molecular genetic techniques in fisheries. In: CARVALHO, G. R.; PITCHER, T. J. (eds.), Molecular genetics in fisheries, Reviews in Fish Biology and Fisheries, v. 4, p. 272-299, 1994.

PASSOS, K. B.; LEÃO, A. S. A.; OLIVEIRA, D. P.; FARIAS, I. P.; HRBEK, T.; Polymorphic microsatellite markers for the overexploited Amazonian fish, Semaprochilodus insignis(Jardine and Schomburgk 1841). Conservation Genetic Resources, v. 2, p. 231-234, 2010.

PAZZA, R.; KAVAlCO, K. F.; PRIOLI, S. M. A. P.; PRIOLI, A. J.; BERTOLlO, L. A. C. Chromosome polymorphism in Astyanax fasciatus (Teleostei, Characidae), Part 3: Analysis of the RAPD and ISSR molecular markers. Biochemical Systematics and Ecology, v. 35, p. 843-851, 2007.

PENNER, G. A.; BUSH, A.; WISE, R.; KIM, W.; DOMIER, L.; KASHA, K.; LAROCHE, A.; SCOLES, G.; MOLNAR, S. J.; FEDAK, G. Reproducibility of random amplified 
polymorphic DNA (RAPD) analysis among laboratories. PCR Methods and Applications, v.2, p. 341-345, 1993.

PEREIRA L. H. G.; FORESTI F.; OLIVEIRA C. Genetic structure of the migratory catfish Pseudoplatystoma corruscans(Siluriformes: Pimelodidae) suggests homing behaviour. Ecology of Freshwater Fish, v. 18, p. 215-225, 2009.

PERES, M. D.; VASCONCELOS, M. S.; RENESTO, E. Genetic variability in Astyanax altiparanae Garutti \& Britski, 2000 (Teleostei, Characidae) from the Upper Paraná River basin, Brazil. Genetics and Molecular Biology, v. 28, p. 717-724, 2005.

PERES, M. D.; RENESTO, E.; LAPENTA, A.S.; ZAWADZKI, C.H. Genetic variability in Hoplias malabaricus(Osteichthyes, Erytrinidae) in fluvial and lacustrine environments in the Upper Paraná River floodplain (Paraná State, Brazil). Biochemical Genetics, v 40, p. 209 223, 2002.

PEREIRA, R. P.; SANTOS, C. H. A.; NASCIMENTO, P. R. M; CLÍMACO, G. T.; SOUSA, A. C. B.; CAMPOS, T.; VERGUEIRO-JR.; A. M. K., PAULA-SILVA, M. N.; ALMEIDAVAL, V. M. F. Isolation of microsatellite loci in the Amazon sailfin catfish Pterygoplichlhys pardalis (Castelneau, 1855) (Teleostei: Loricariidae). Conservation Genetic Resources, v. 4, p. 889-891, 2012.

PEREYRA, S.; GARCÍA, G. Patterns of genetic differentiation in the Gymnogeophagus gymnogenys species complex, a neotropical cichlid from South American basins. Environmental Biology of Fishes, v. 83, p.245-257, 2008.

PERRY, J.C.; ROWE, L. Rapid microsatellite development for water striders by next-generation sequencing. Journal of Heredity, v. 102, p. 125-129, 2010.

PETRERE-JR.; M. A pesca de água doce no Brasil. Ciência Hoje, v.19, p.28-33, 1995.

PETRERE-JR., M.; WALTER, T.; MINTE-VERA, C.V. Income evaluation of small - scale fishers in two Brazilian urban reservoirs: Represa Billings (SP) and Lago Paranoá (DF).Brazilian Journal of Biology, v. 66, p. 817-828, 2006.

PICARD, D.J.; SCHULTE, P.M. Variation in gene expression in response to stress in two populations of Fundulus heteroclitus. Comparative Biochemistry and Physiology Part A, v. 137, p. 205-216, 2004.

PIGLIUCCI, M. How organisms respond to environmental changes: from phenotypes to molecules (and vice versa). Trends in Evolution and Ecology, v. 11, p.168-173, 1996.

PINEDA-SANTIS, H.; PAREJA, M.D.; OLIVEIRA, M.A.; BUILES, J.G. Contribución a la relación taxonómica entre cuatro especies de peces de la familia Characidae mediante el polimorfismo de ADN amplificado al azar (RAPD). Revista Colombiana de Ciencias Pecuarias, v. 17 , p. 30-37, 2004a. 
PINEDA-SANTIS, H.; PAREJA, M. D.; BUILES, J. G.; OLIVEIRA, M. A. Análisis de la variación genética en Piaractus brachypomus (Pisces, Characidae) en estaciones piscícolas colombianas mediante RAPD. Revista Colombiana de Ciencias Pecuarias, v. 17, p. $17-$ 23, 2004b.

PINEDA-SANTIS, H.; OLIVERA, M. A.; URCUQUI S. I.; TRUJILLO, E. B.; BUILES, J. G. Evaluación del polimorfismo por microssatélites en individuos de Piaractus brachypomus (Characidae, Serrasalminae) provenientes del río Meta, Colombia. Revista Colombiana de Ciencias Pecuarias, v. 19, v. 66-69, 2006.

PINDEA-SANTIS, H.; ARBOLEDA, L. C.; ECHEVERRY, A. E.; URCUQUI, S. I.; PAREJA, M. D.; OLIVEIRA, M. A.; BUILES, J. G. Caracterización de la diversidad genética en el pez Brycon henni (Characiformes: Characidae) en Colombia central por medio de marcadores RAPD. Revista de Biología Tropical, v. 55, p. 1025-1035, 2007.

PLUCKNET'T, D. L.; SMITH, N. J. H.; WILlIAMS, J. T.; ANISHETTY, N. M. Crop germplasm conservation and developing countries. Science, v. 220, p. 163-169, 1983.

POMPANON, F.; BONIN, A.; BELLEMAIN, E.; TABERLET, P. Genotyping errors: causes, consequences and solutions. Nature Reviews Genetics, v. 6, p. 847-859, 2005.

POTTINGER, T.G.; CARRICK, T.R. Modification of the plasma cortisol response to stress in rainbow trout by selective breeding. General and Comparative Endocrinology, v. 116, p. 122-132, 1999.

PORTO-FORESTI, F.; HASHIMOTO, D. T.; SENHORINI, J. A.; FAUSTO FORESTI, F. Hibridação em piscicultura: monitoramento e perspectivas. In: BALDISSEROTTO, B.; GOMES, L.C. (eds), Espécies nativas para piscicultura no Brasil, 2a. Ed., Editora UFSM, Santa Maria, 2010. p. 589-606.

PORTO-FORESTI, F.; HASHIMOTO, D. T.; PRADO, F. D.; SENHORINI, J. A.; FORESTI, F.. A Hibridação interespecífica em peixes. Panorama da Aquicultura, v. 126, 2011, p. 28 33

POVH, J. A.; RIBEIRO, R. P.; SIROL, R. N.; STREIT-JR, D. P.; LOPERA-BARRERO, N. M.; VARGAS, L.; GOMES, P. C.; LOPES, T.S. Diversidade genética de pacu do Rio Paranapanema e do estoque de um programa de repovoamento. Pesquisa Agropecuária Brasileira, v. 43, p. 201-206, 2008.

POVH, J. A.; RIBEIRO, R. P.; LOPERA-BARRERO, N. M.; GOMES, P. C.; BLANCK, D. V.; VARGAS, L.; JACOMETO, C. B.; LOPES, T. S. Monitoramento da variabilidade genética de pacu, Piaractus mesopotamicus, do programa de aumento de estoque do rio Paranapanema. Arquivo Brasileiro de Medicina Veterinária e Zootecnia, v. 61, p.1191-1195, 2009. 
PRADO, F. D.; HASHIMOTO, D. T.; SENHORINI, J. A.; FORESTI, F.; PORTO-FORESTI, F. Detection of hybrids and genetic introgression in wild stocks of two catfish species (Siluriformes: Pimelodidae): The impact of hatcheries in Brazil. Fisheries Research, v. 125, p. 300-305, 2012.

PRIOLI, S. M. A. P.; PRIOLI, A J.; JULIO JR., H.F.; PAVANELLI C.S.; OLIVEIRA, A.V.; CARRER, H.; CARRARO, D.M.; PRIOLI, L.M. Identification of Astyanax altiparanae(Teleostei, Characidae) in the Iguaçu River, Brazil, based on mitochondrial DNA and RAPD markers. Genetics and Molecular Biology, v.25: p. 421-430, 2002.

PULLIN, R. S. V. (ed.). Tilapia genetic resources for Aquaculture. ICLARM Proceedings 16, International Center for Living Aquatic Resources Management, Manila, Philippines, 1988. $108 \mathrm{p}$.

PULLIN, R. S. V.; Casal, C. M. V. (eds). Consultation on fish genetic resources. JCLARM Conf. Proc. 51, 1996. 61 p.

RAMELLA, M. S.; KROTH, M. A.; MEURER, S.; NUÑER, A. P. O.; FILHO, E. Z.; ARISI, A. C. M. Genetic Variability in Four Fish Species (Pimelodus maculatus, Prochilodus lineatus, Salminus brasiliensis and Steindachneridion scripta) from Uruguay River Basin. Brazilian Archives of Biology and Technology, v. 49, p. 589-598, 2006.

RAMOS, J. V. B.; SODRE, L. M. K.; ORSI, M. L.; ALMEIDA, F. S. Genetic diversity of the species Leporinus elongatus (Teleostei: Characiformes) in the Canoas Complex - Paranapanema River.Neotropical Ichthyology, v. 10, p. 821-828, 2012.

REED, D.H.; FRANKHAM, R. Correlation between fitness and genetic diversity. Conservation Biology, v 17, p. 230-237, 2003.

REIS, R.E.; KULLANDER, S.O.; FERRARIS-JR, C.J. (eds.). Checklist of the freshwater fishes of South and Central América. Porto Alegre, EDIPUCRS, 2003. 729 p.

REIS-NETO, R. V.; SERAFINI, M. A., RILKE FREITAS, R. F. F.; ALLAMAN, I. B.; MOURAD, N. M. N.; ALINE DE ASSIS LAGO, A. A. Performance and carcass traits in the diallel crossing of pacu and tambaqui.Revsita Brasileira de Zootecnia, v. 41, n.12, p. 2390-2395, 2012.

RENESTO E.; ZAWADZKI, C. H.; REVALDAVES, E. Genetic evidence for two species of the genus PimelodusLacépède, 1803 (Siluriformes, Pimelodidae) in the Iguaçu River (Brazil). Genetics and Molecular Biology, v. 23, p. 809-813, 2000.

RENNO, J-F.; BERREBI, P.; BOUJARD, T.; GUYOMARD, R. Intraspecific genetic differentiation of Leporinus friderici (Anostomidae, Pisces) in French Guiana and Brazil: a genetic approach to the refuge theory. Journal of Fish Biology, v. 36, p. 83-95, 1990. 
RENNO, J-F.; MACHORDOM, A.; BLANQUER, A.; BLANQUER, A.; BOURSOT, P. Polymorphism of mitochondrial genes in populations of Leporinus friderici (Bloch, 1794): intraspecific structure and zoogeography of the Neotropical fish. Genetica, v. 84, p. $137-$ 142, 1991.

RENNO, J-F.; HUBERT, N.; TORRICO, J. P.; DUPONCHELLE, F.; RODRIGUEZ, J. N.; DAVILA, C. G.; WILLIS, S. C.; DESMARAIS, E. Phylogeography of Cichla (Cichlidae) in the upper Madera basin (Bolivian Amazon). Molecular Phylogenetics and Evolution, v. 41, p. 503-510, 2006.

REUSING, A.F.; RENESTO, E.; ROXO, F.F.; ZAWADZKI, C.H. Allozyme differentiation of two populations of the genus Neoplecostomus Eigenmann \& Eigenmann, 1888 (Teleostei, Loricariidae) from the upper Paraná River basin, Brazil. Genetics and Molecular Biology, v. 34, p. 496-501, 2011.

REVALDAVES, E.; RENESTO, E.; MACHADO, M. F. P. S. Genetic variability of Prochilodus lineatus (Characiformes, Prochilodontidae) in the upper Paraná Rivers. Brazilian Journal of Genetics, v. 20, p. 381-388, 1997.

REVAlDAVES, E.; PEREIRA, L. H. G.; FORESTI, F.; OLIVEIRA, C.. Isolation and characterization of microsatellite loci in Pseudoplatystoma corruscans (Siluriformes: Pimelodidae) and cross-species amplification. Molecular Ecology Notes, v. 5, p. 463-465, 2005.

REZENDE, J.R.; RENESTO, E.; ZAWADZKI, C.H.; Genetic variability in three species of Gymnotus Linnaeus, 1758 (Gymnotiformes: Gymnotidae) from Caracu stream of the upper Paraná River basin, Brazil. Neotropical Ichthyology, v. 7, p. 623-628, 2009.

RIBOLLI, J.; MELO, C. M. R.; ZANIBONI-FILHO, E. Genetic characterization of the Neotropical catfish Pimelodus maculatus (Pimelodidae, Siluriformes) in the Upper Uruguay River. Genetics and Molecular Biology, v. 35, p. 761-769, 2012.

RICO, C.; RICO, I.; HEWITT, G. 470 million years conservation of microsatellites loci among fish species. Proceedings of the Royal Society B: Biological Sciences, v. 263, p. 549-557, 1996.

RIDGWAY, G. J.; CUSHING, J. E.; DURALL, G. L. Serological differentiation of populations of sockeye salmon, Oncorbynchus nerka. Special Scientific Report Fisheries, no. 257, 1958. 9 p.

RODRIGUES, F. G.; FARIAS, I. P.; BATISTA, J. S.; ALVES-GOMES, J. Isolation and characterization of microsatellites loci for "piramutaba" (Brachyplatystoma vaillantii, Siluriformes: Pimelodidae), one of the commercially most important migratory catfishes in the Amazon Basin. Conservation Genetic Resources, v. 1, p. 365-368, 2009. 
ROSA, R.S.; LIMA, F.C. Os peixes brasileiros ameaçados de extinção. 1ed. In:MACHADO, A. B. M.; DRUMMOND, A. M.; PAGLIA, A.P. (eds), Livro vermelho da fauna brasileira ameaçada de extinção. Belo Horizonte: Fundação Biodiversitas, 2008.1420 p.

ROYCE, W. F. Statistical comparison of morphological data. In: MARR, J.C. (ed.) Contributions to the Study of Subpopulations of Fishes. Spec. Sci. Rep. Fisheries series, no. 208. U.S. Fish and Wildlife Serv., 1957. p. 7-28.

RUEDA, E. C.; SOMMER, J.; SCARABOTTI, P.; MARKARIANI, R.; ORTÍ, G. Isolation and characterization of polymorphic microsatellite loci in the migratory freshwater fish Prochilodus lineatus (Characiformes: Prochilodontidae). Conservation Genetic Resources, v. 3, p. $681-$ 684, 2011.

RUEDA, E. C.; AMAVET, P.; BRANCOLINI, F.; SOMMER, J.; ORTÍ, G. Isolation and characterization of eight polymorphic microsatellite markers for the migratory characiform fish, Salminus brasiliensis. Journal of Fish Biology, v.79, p. 1370-1375, 2011.

RYMAN, N., LEIMAR, O. $\mathrm{G}_{S T}$ is still a useful measure of differentiation comment on Jost's D. Molecular Ecology, v. 18, p. 2084-2087, 2009.

SACHIDANANDAM, R.; WEISSMAN, D.; SCHMIDT, S.; KAKOL, J.; STEIN, L.; MARTH, G.; SHERRY, S.; MULLIKIN, J.; MORTIMORE, B.; WILLEY, D.; HUNT, S.; COLE, C.; COGGILL, P.; RICE, C.; NING, Z.; ROGERS, J.; BENTLEY, D.; KWOK, P.; MARDIS, E.; YEH, R.; SCHULTZ, B.; COOK, L.; DAVENPORT, R.; DANTE, M.; FULTON, L.; HILLIER, L.; WATERSTON, R.; MCPHERSON, J.; GILMAN, B.; SCHAFFNER, S.; VAN ETTEN, W.; REICH, D.; HIGGINS, J.; DALY, M.; BLUMENSTIEL, B.; BALDWIN, J.; STANGE-THOMANN, N.; ZODY, M.C.; LINTON, L.; LANDER, E.S.; ALTSHULER, D. A map of human genome sequence variation containing 1.42 million single nucleotide polymorphisms. Nature, v. 409, p. 928-33, 2001.

SAIKI, R.K.; GELFAND, D.H.; STROFFEL, S.; SCHARF, S.J.; HIGUCHI, R.; HORN, G.T.; MULLIS, K.B.; ERLICH, H.A. Primer-directed enzyme amplification of DNA with thermostable DNA polymerase. Science, v. 239, p: 487-491, 1988.

SANCHES, A.; GALETTIIJR, P. M. Microsatellites loci isolated in the freshwater fish Brycon hilarii. Molecular Ecology Notes, v. 6, p. 1045-1046, 2006.

SANCHES, A.; GALETTI-JR, P.M. Genetic evidence of population structuring in the neotropical freshwater fish Brycon hilarii(Valenciennes, 1850). Brazilian Journal of Biology, v. 67 (Suppl.4), p. 889-895, 2007.

SANCHES, A.; GALETTI-JR., P.M.; GALZERANI, F., DERAZO, J.; CUTILAK-BIANCHI, B.; HATANAKA, T. Genetic population structure of two migratory freshwater fish species (Brycon orthotaenia and Prochilodus argenteus) from the São Francisco River in Brazil and its 
significance for conservation. Latin American Journal of Aquatic Research, v. 40, p. 177186, 2012.

SANCHES, A.; GALETTI-JR, P. M. 2012. Population genetic structure revealed by a school of the freshwater migratory fish, Brycon bilarii. Latin American Journal of Aquatic Research, v. 40, p. 408-417, 2012.

SANTOS, M. C. F.; RUFFINO, M. L.; FARIAS, I. P. 2007. High levels of genetic variability and panmixia of the tambaqui Colossoma macropomum(Cuvier, 1816) in the main channel of the Amazon River. Journal of Fish Biology, v. 71(suppl A), p.33-44, 2007.

SANTOS, M. C. F.; HRBEK, T.; FARIAS, I. P. Microsatellite markers for the tambaqui (Colossoma macropomum, Serrasalmidae, Characiformes), an economically important keystone species of the Amazon River floodplain. Molecular Ecology Resources, v. 9, p. 874-876, 2009.

SANTOS, C. H. A.; SOUSA, C. F. S.; PAULA-SILVA, M. N.; VAL, A. L.; ALMEIDA-VAL, V. M. F. Genetic Diversity in Cichla monoculus (Spix and Agassiz, 1931) Populations: Implications for Management and Conservation. American Journal of Environmental Sciences, v. 8, p. 35-41, 2012.

SANTOS, C. H. A.; LEITÃO, M. A. B.; SOUSA, C. F. S.; SANTANA, G. X.; PAULA-SILVA, M. N.; ALMEIDA-VAL, V. M. F. 2012. Genetic variability of wild and captivity populations of Colossoma macropomum (Cuvier, 1818). Acta Scientiarum. Biological Sciences Maringá, 34, 191-197.

SATO, Y.; GODINHO; H. P.; TORQUATO, V. C.; BARBOSA, N. D. C. 2006. Ictiofauna no rio São Francisco. In: ÁVILA, F. (ed.), Guia ilustrado de peixes do rio São Francisco de Minas Gerais. Empresa das Artes, São Paulo, SP, Brasil, 2006. p. 69-116.

SAUER, C. O. Agricultural Origins and Dispersals, American Geographical Society, George Grady Press, New York, 1952. 110 p.

SAULO-MACHADO, A. C.; FORMIGA, K. M.; ORTIZ, M. F.; SOUSA, A. C. B.; ALVESGOMES, J. A.; BATISTA, J. S. Polymorphic microsatellite DNA markers for the Amazonian catfish Pseudoplatystoma punctifer (Siluriformes: Pimelodidae). Conservation Genetic Resources, v. 3, p. 307-310, 2011.

SAVOLAINEN, P.; ZHANG, Y.; LUO, J.; LUNDEBERG, J.; LEITNER, T. Genetic evidence for an East Asian origin of domestic dogs. Science, v. 298, p.1610-1613, 2002.

SCHNEIDER, S.; KUEFFER, J.-M.; ROESSLI, D.; EXCOFFIER, L. 1997. Arlequin ver. 1.1: A software for population genetic data analysis. Genetics and Biometry Laboratory, University of Geneva, Switzerland. 
SCHNEIDER, C. H.; GROSS, M. C.; TERENCIO, M. L.; PORTO, J. I. R. Cryptic diversity in the mtDNA of the ornamental fish Carnegiella strigata. Journal of Fish Biology, v.81, p. 1210-1224, 2012.

SCHUG, M. D.; DOWNHOWER, J. F.; BROWN, L. P.; SEARS, D. B.; FUERST, P.A. Isolation and genetic diversity of Gambusia hubbsi (mosquitofish) populations in blueholes o andors Island, Bahamas. Heredity, v. 80, p. 336-346, 1998.

SCHWAGER, S. J.; MUTSCHLER, M. A.; FEDERER, W. T.; SCULLY, B. T.; The effect of linkage on sample size determination for multiple trait selection. Theoretical and Applied Genetics, v. 86, p. 964-974, 1993.

SCORVO-FILHO, J. D.; FRASCÁ-SCORVO, C.M.D., ALVES, J.M.C.; SOUZA, F.R.A. A tilapicultura e seus insumos, relações econômicas. Revista Brasileira de Zootecnia, v. 39, p. $112-118,2010$.

SCHLÖTTERER, C. The evolution of molecular markers - just a matter of fashion?. Nature Reviews, v. 5, p. 63-69, 2004.

SEKINE, E. S.; PRIOLI, A. J.; PRIOLI, S. M. A. P.; JÚLIO-JR., H. F. Genetic differentiation among populations of Pseudoplatystoma corruscans (Agassiz, 1829) (Osteichthyes, Pimelodidae) isolated by the Guaíra Falls in the Paraná River. Acta Scientiarum, v. 24, p. 507-512, 2002.

SHAW, C. R.; PRASAD, R. Starch gel electrophoresis of enzymes - A compilation of recipes. Biochemical Genetics, v. 4, p. 297-320, 1970.

SHEN, X.; YANG, G.; LIAO, M. 2007. Development of 51 genomic microsatellite DNA markers of guppy (Poecilia reticulata) and their application in closely related species. Molecular Ecology Notes, v. 7, p. 302-306, 2007.

SHRIVER, M. D.; JIN, L.; BOERWINKLE, E.; DEKA, E., FERRELL, R. E. CHAKRABORTY, R. A novel measure of genetic distance for highly polymorphic tandem repeat loci. Molecular Biology and Evolution, v. 12, p. 914-920, 1995.

SILVA, E. P.; RUSSO, C. A. M. Techniques and statistical data analysis in molecular population genetics. Hydrobiologia, v. 420, p. 119-135, 2000.

SILVA, J. V.; HILSDORF, A. W. S. isolation and characterization of polymorphic microsatellite loci from salminus hilarii (characiformes: characidae). Conservation Genetic Resources, v. 3, p 437-439, 2011.

SILVA, J. V. Caracterização da diversidade genética da tabarana, Salminus hilarii (Valenciennes, 1849) (Characiformes: Characidae) da bacia do alto paraná por marcadores microssatélites. 2009. 114 f., Dissertação de Mestrado, Universidade de Mogi das Cruzes. 
SIMON, D.L. Conservation of animal genetic resources a review. Livestock Production Science, v. 11, p. 23-36, 1984.

SIMPSON, B.; HAFFER, J. Speciation patterns in the Amazonian forest biota. Annual Review of Ecology and Systematics, v. 9, p. 497-518, 1978.

SIVASUNDAR, A.; BERMINGHAM, E.; ORTÍ, G. Population structure and biogeography of migratory freshwater fishes (Prochilodus : Characiformes) in major South American rivers. Molecular Ecology, v. 10, p. 407-417, 2001.

SLATKIN, M. A measure of population subdivision based on microsatellite allele frequencies. Genetics, v. 139, p. 457-462, 1995a

SLATKIN, M. A measure of population subdivision based on microsatellite allele frequencies Genetics, v. 139, p. 1463 (erratum), 1995b.

SMITHIES, O. Zone electrophoresis in starch gels: group variations in the serum proteins of normal adults Biochemical Journal, v. 61, p. 629-641, 1955.

SMITH, P.J.; JAMIESON, A.; BIRLEY, A.J. Electrophoretic studies and stock concept in Marine Teleosts. Journal du Conseil Permanent International Pour L Exploration de la Mer, v. 47, p. 231-245, 1990.

SOFIA, S. H.; SILVA, C. R. M.; GALINDO, B. A.; ALMEIDA, F. S.; LEDA M. K.; SODRÉ, L. M. K.; MARTINEZ, C. B. R. Population genetic structure of Astyanax scabripinnis(Teleostei, Characidae) from an urban stream. Hydrobiologia, v. 553, p. 245-254, 2008.

SOUTHERN, E. M. Detection of specific sequences among DNA fragments separated by gel electrophoresis. Journal of Molecular Biology, v. 98, p. 503-507, 1975.

SOUSA, C. F. S.; SANTOS, C. H. A.; SOUSA, A. C. B.; PAULA-SILVA, M. N.; SOUZA, A. P.; FARIAS, I. P.; FERREIRA-NOZAWA, M. S.; ALMEIDA-VAL, V. M. F. Development and characterization of microsatellite markers in Astronotus crassipinis(Heckel, 1840). Conservation Genetic Resources, v. 1, p. 277-280, 2009.

SOUZA, C. A; HASHIMOTO, D. T.; PEREIRA, L. H. G.; OLIVEIRA, C.; FORESTI, F.; PORTO-FORESTI, F. Development and characterization of microsatellite loci in Phractocephalus hemioliopterus (Siluriformes: Pimelodidae) and their cross-species amplification in six related species. Conservation Genetic Resources, v. 4, p. 499-501, 2012.

STRECKER, U. Polymorphic microsatellites isolated from the cave fish Astyanax fasciatus. Molecular Ecology Notes, v.3, p. 150- 151, 2003.

SUZUKI, A. Serological studies of the races of tuna VI. Bigeye-3 antigens occurred in the albacore. Report of Nankai Regional Fisheries Research Laboratory, v.16, p. 67-70, 1962. 
SUK, H. Y.; NEFF, B. D. Microsatellite genetic differentiation among populations of the Trinidadian guppy. Heredity, v. 102, p. 425-434, 2009.

TAGGART, J. B.; VERSPOOR, E.; GALVIN, P.; MORAN, P.; FERGUSON, A. A minisatellite DNA marker for discriminating between European and North American Atlantic salmon (Salmo salar L.). Canadian Journal of Fisheries and Aquatic Science, v. 52, p. 2305-2311, 1995.

TACON, A. G. J.; METIAN, M. Fish matters: importance of aquatic foods in human nutrition and global food supply. Reviews in Fisheries Science, v. 21, p. 22-38, 2013.

TAYLOR, E. B. Genetic variation at minisatellite DNA loci among North Pacific populations of steelhead and rainbow trout (Oncorbynchus mykiss). Heredity, v. 86, p. 354-363, 1995.

TAKAHATA, N.; NEI, M. $\mathrm{F}_{S T}$ and $\mathrm{G}_{S T}$ statistics in the finite island model (Letter to the Editor). Genetics, v. 107, p. 501-504, 1984.

TELLES, M. P. C.; RESENDE, L. V.; BRONDANI, R. P. V.; COLLEVATTI, R. G.; COSTA, M. C.; SILVA-JR., N. J. Isolation and characterization of microsatellite markers in the armored catfish Hypostomus gymnorbynchus (Loricariidae). Genetics and Molecular Research, v. 9, p. 1770-1774, 2011.

TElles, M. P. C.; COLleVATTI, R. G.; COSTA, M. C.; BARTHEM, R. B.; SILVA-JR., N. J.; NETO, A. C. S.; DINIZ-FILHO, J. A. F. A geographical genetics framework for inferring homing reproductive behavior in fishes. Genetica, v. 139, p. 243-253, 2011.

TERENCIO, M. L.; SCHNEIDER, C. H.; PORTO, J. I. R. Molecular signature of the D-loop in the brown pencilfish Nannostomus eques (Characiformes, Lebiasinidae) reveals at least two evolutionary units in the Rio Negro basin, Brazil. Journal of Fish Biology, 81, p. 110-124, 2012.

THOMAS, C. D.; CAMERON, A.; GREEN, R. E.; BAKKENES, M.; BEAUMONT, L. J.; COLLINGHAM, Y. C.; ERASMUS, B. F. N.; SIQUEIRA, M. F.; GRAINGER, A.; HANNAH, L.; HUGHES, L.; HUNTLEY, B.; VAN JAARSVELD, A. S.; MIDGLEY, G. F.; LERA MILES, L.; ORTEGA-HUERTA, M.A., TOWNSEND, A.; PETERSON, A. T.; OLIVER, L.; PHILLIPS, O. L.; WILLIAMS, S. E. Extinction risk from climate change. Nature, v. 427, p. 145-148, 2004.

TILMAN, D.; MAY, R.; LEHMAN, C.L.; NOWAK., M.A. Habitat destruction and the extinction debt. Nature, v. 371, p. 65-66, 1994.

TISELIUS, A. W. K. A new apparatus for electrophoretic analysis of colloidal mixtures. Transactions of the Faraday Society, v.33, p. 524-531, 1937.

TOLEDO-FILHO, S. A.; RIBEIRO, A. F. Evolução das isozimas da desidrogenase láctica em peixes. Ciência e Cultura, v. 29, p. 40-44, 1977. 
TOLEDO-FILHO, S. A.; FORESTI, F.; RIBEIRO, A. F. Ictiogenética: aspectos básicos e aplicados. Ciência e Cultura, v. 30, p. 320-327, 1978.

TOLEDO-FILHO, S. A.; ALMEIDA-TOLEDO, L. F.; FORESTI F.; BERNADINO, G.; CALCAGNOTTO, D. Cadernos de Ictiogenética no. 2: Monitoramento e conservação em projetos de hibridização entre pacu e tambaqui. Depto. de Biologia, CCS/USP, 1994. 60p.

TORRES, R. A.; MOT'TA, T. S.; NARDINO, D.; ADAM, M. L.; RIBEIRO, J. Chromosomes, RAPDs and evolutionary trends of the Neotropical fish Mimagoniates microlepis (Teleostei: Characidae: Glandulocaudinae) from coastal and continental regions of the Atlantic forest, Southern Brazil. Acta Zoologica, v. 89, p. 253-259, 2008.

TORRES, R. A.; RIBEIRO, J. The remarkable species complex Mimagoniates microlepis(Characiformes: Glandulocaudinae) from the Southern Atlantic Rain forest (Brazil) as revealed by molecular systematic and population genetic analyses. Hydrobiologia, v. 617, p. 157-170, 2008.

TURNER, T. F.; MCPHEE, M. V.; CAMPBELL, P.; WINEMILLER, K. O. Phylogeography and intraspecific genetic variation of prochilodontid fishes endemic to rivers of northern South America. Journal of Fish Biology, v. 64, p. 186-201, 2004.

TURNER, B. J.; DUVERNELL, D. D.; BUNT, T. M.; BARTON, M. G. Reproductive isolation among endemic pupfishes (Cyprinodon) on San Salvador Island, Bahamas: microsatellite evidence. Biological Journal of the Linnean Society, v. 95, p. 566-582, 2008.

UNEP. United Nations Environment Programme. Intergovernmental Negotiating Committee for a Convention on Biological Diversity. Unpublished working paper, fourth negotiating sessionsecond session of INC, Nairobi, UNEP Bio.Div.N4-INC.2rCRP.1. 1991. Disponível em: <http://www.cbd.int/doc/handbook/cbd-hb-09-en.pdf>. Acesso em 10 jan 2013.

UNEP. Global biodiversity assessment: summary for policymakers. United Nations Environment Programme, Cambridge University Press, Cambridge, UK, 1995. 46 p.

UNFPA. The State of World Population 2011, People and possibilities in a world of 7 billion, United Nations Population Fund, New York, 2011, 124 p.

UTTER, F. M.; HODGINS, H. O.; ALLENDORF, F. W. Biochemical genetic studies of fishes: Potentialities and limitations. In: MALINS, D. C., SARGENT, J. R. (eds), Biochemical and biophysical perspectives in marine biology. Vol. I, Academic Press, New York, 1974. p. 213-238.

VAL, A. L.; MARCON; J.L.; COSTA; O.T.F.; BARCELLOS; J.F.M.; MACO-GARCIA, J.T.; ALMEIDA-VAL. V.M.F. Fishes of the Amazon: Surviving environmental changes. In: 
SAKSENA, D.N. (ed.) Ichthyology - Recent research advances. Science Publishers, Enfield, NH, USA. 1998. p. 389-402.

VAL, A.L.; ALMEIDA-VAL, V.M.F. Volume overview: Biology of tropical fish. In: A.L. VAL.; ALMEIDA-VAL, V.M.F. (eds). Biology of Tropical Fishes. INPA, Manaus, AM, Brazil . 1999. p. 1-4.

VANDEPUTTE, M.; PRUNET, P. Génétique et adaptation chez les poissons: domestication, résistance au stress et adaptation aux conditions de milieu. INRA Productions Animales, v. 15, p. 365-371, 2002.

VANHAECKE, D.; LEANIZ, C. G.; GAJARDO, G.; THOMAS., C. J.; CONSUEGRA, S. Metapopulation dynamics of a diadromous galaxiid fish and potential effects of salmonid aquaculture. Freshwater Biology, v. 57, p. 1241-1252, 2012.

VAVILOV, N. I. Studies on the origin of cultivated plants. Trudi po Prikladnoi Botanike, Genetike i Selektsii (Bulletin of Applied Botany, Genetics and Plant Breeding), v. 16, p. 139-248, 1926 (em Russo).

VAVILOV, N. I. Origin and Geography of Cultivated Plants. [Translated from Russian by Doris Love], Cambridge University Press, Cambridge, UK, 1992.532 p.

VICENTE, M. C.; LÓPEZ, C.; FULTON, T. (eds.). Genetic Diversity Analysis with molecular Marker Data: Learning Module. International Plant Genetic Resources Institute (IPGRI), Rome, Italy, 2004.

VIGNAL, A.; MILAN, D.; SANCRISTOBAL, M.; EGGEN, A. A review on SNP and other types of molecular markers and their use in animal genetics. Genetic, Selection, Evolution, v. 34, p. 275-305, 2002.

VIGNE, J-D., The origins of animal domestication and husbandry: A major change in the history of humanity and the biosphere. Comptes Rendus Biologies, v. 334, p. 171-181, 2011.

VILAR, J. A. Avaliação genética populacional do Surubim-do-Paraíba (Steindachneridion parahybae, Siluriformes, Pimelodidae) na bacia do Paraíba do Sul por meio de marcadores microssatélites e DNA mitocondrial. 2012. 111 f. Dissertação de Mestrado, Universidade de Mogi das Cruzes, 2012.

VITOUSEK, P. M.; MOONEY, H. A.; LUBCHENCO, J.; MELILLO, J. M. Human domination of earth's ecosystems. Science, v. 277, p. 494-499, 1997.

VOS P.; HOGERS, R.; BLEEKER, M.; REIJANS, M.; VAN DE LEE, T.; HORNES, M.; FRIJTERS, A.; POT. J.; PELEMAN, J.; KUIPER, M.; ZABEAU, M. AFLP: a new technique for DNA fingerprinting. Nucleic Acids Research, v. 23, p. 4407-4414, 1995. 
VU, V.; CHRISTMAN, J.; CALLE, P.; AGUIRRE, W. E. Isolation of microsatellite loci for the predatory fish Hoplias microlepis (Characiformes: Erythrinidae) from a highly impacted river system in western Ecuador. Conservation Genetic Resources, v. 5, p. 437-439, 2013.

XIAO-GU, Z.; JIN-GOU, T.; BANG-XI, X.; Applications of microsatellite markers in studies of genetics and breeding of fish. Chinese Journal of Agricultural Biotechnology, v. 3, p. 83$87,2006$.

WALKER, I. Prediction or Evolution? Somatic plasticity as a basic, physiological condition for the variability of genetic mutations. Acta Biotheoretica, v. 44, p. 165-168, 1997.

WALTER, R. P.; BLUM, M. J.; SNIDER, S. B.; PATERSON, I. G.; BENTZEN, P.; LAMPHERE, B. A.; GILLIAM, J. F. Isolation and differentiation of Rivulus hartiiacross Trinidad and neighboring islands. Molecular Ecology, v. 20, p. 601-618, 2011.

WANG, S.; HARD, J.H.; UTTER. F. Genetic variation and fitness in salmonids. Conservation Genetics, v. 3, p: 321-333, 2002.

WAPLES, R. S.; GAGGIOTTI, O. What is a population? An empirical evaluation of some genetic methods for identifying the number of gene pools and their degree of connectivity. Molecular Ecology, v. 15, p. 1419-1439, 2006.

WARD, R. D.; WOODWARK, M.; SKIBINSKI, D. O. F. A comparison of genetic diversity levels in marine, freshwater and anadromous fishes. Journal of Fish Biology, v. 44, p. $213-$ 232, 1994.

WASKO, A. P.; GALETTI-JR. PCR primed with minisatellite core sequences yields speciesspecific patterns and assessment of population variability in fishes of the genus Brycon. Journal of Applied Ichthyology, v. 19, p. 109-113, 2003.

WASKO, A. P.; GALETTI-JR., P. M. RAPD analysis in the Neotropical fish Brycon lundii; genetic diversity and its implications for the conservation of the species. Hydrobiologia, v. 474, p. 131-137, 2002.

WASKO, A. P.; MARTINS, C.; OLIVEIRA, C.; SENHORINI, J. A.; FORESTI, F. Genetic monitoring of the Amazonian fish matrinchã (Brycon cephalus) using RAPD markers: insights into supportive breeding and conservation programmes. Journal of Applied Ichthyology, v. 20, p. 48-52, 2004.

WEBER, J. L.; MAY, P. E. Abundant class of human DNA polymorhisms which can be typed using the polymerare chain reaction. American Journal of Human Genetics, v. 44, p. 388396, 1989.

WEINBERG, W. 1908. Über den Nachweis der Vererbung beim Menschen. Jahreshefte des Vereins für vaterländische Naturkunde in Württemberg64: 368-382. 
WEIR, B. S. Genetic Data Analysis II: Methods for Discrete Population Genetic Data. Sinauer Associates, Inc. Sunderland, Massachusetts, 1996. 445 p.

WEIR, B. S.; COCKERHAM, C.C. Estimating F-statistics for the analysis of population structure. Evolution, v. 38, p.1358-1370, 1984.

WELCOMME, R. L. International introductions of inland aquatic species. Fisheries Technical Paper 294. Food and Agriculture Organization of the United Nations. Rome, 1988. $318 \mathrm{p}$.

WELCOMME, R. Review of the State of the World Fishery Resources: Inland Fisheries. FAO Fisheries and Aquaculture Circular No. 942, Rev. 2. Food and Agriculture Organization of the United Nations. Rome, 2011. 97 pp.

WELSH, J.; McCLELLAND, M. Finger printing genomes using PCR with arbitrary primers. Nucleic Acids Research, v.18, p. 7213-7218,1990.

WHITE, P. S.; DENSMORE, L. D. Mitochondrial DNA isolation. In: HOELZEL, A. R. (ed), Molecular genetic analysis of populations: a practical approach, Oxford University Press, New York, 1992. p. 29-58

WHITMORE, D. H. Electrophoretic and isoelectric focusing techniques in fisheries management. CRC Press, Boca Raton, Florida, 1990, 350 p.

WILLIAMS, J. G. K.; KUBELIK, A.R.; LIVAK, K. J.; RAFALSKI, J. A.; TINGEY, S. V. DNA polymorphisms amplified by arbitrary primers are useful as genetic markers. Nucleic Acids Research, v.18, p.6531-6535, 1990.

WILLING, E-M.; BENTZEN, P.; VAN OOSTERHOUT, C.; HOFFMANN, M.; CABLE, J.; BREDEN, F.; WEIGEL, D.; DREYER, C. Genome-wide single nucleotide polymorphisms reveal population history and adaptive divergence in wild guppies. Molecular Ecology, v. 19, p. 968-984, 2010.

WILLING, E-M.; DREYER, C.; VAN OOSTERHOUT, C. Estimates of genetic differentiation measured by $\mathrm{F}_{s t}$ do not necessarily require large sample sizes when using many SNP markers. PLoS One, v.7, p. e42649, 2012.

WILLIS, J. C. The endemic flora of Ceylon, with reference to geographical distribution and evolution in general. Philosophical Transactions of the Royal SocietyB, vol. ccvi, 1915. $307 \mathrm{p}$.

WOLFF, K.; SCHOEN, E. D.; PETERS-VAN RIJN, J. Optimizing the generation of random amplified polymorphic DNAs in chrysanthemum. Theoretical and Applied Genetics, v. 86, p.1033-1037, 1993.

WHO. Global Health Observatory, World Health Organization, 2013. Disponível em: http://www.who.int/gho/mortality_burden_disease/life_tables/en/ >. Acesso 13 jan. 2013. 
WRI. World resources institute biodiversity web site. Biodiversity glossary of terms,1996. Disponível em: <http://www.wri.org/publication/content/8142>. Acesso 13 jan. 2013.

WRIGHT, S. The genetical structure of populations. Annals of Eugenics, v. 15, p. 323-354, 1951.

WRIGHT, S. Systems of mating. Genetics, v. 6, p. 111-178, 1921.

WRIGHT, S. The interpretation of population structure by F-statistics with special regard to systems of mating. Evolution, v. 19, p. 395-420, 1965.

WRIGHT, S. Evolution and the Genetics of Population, Variability Within and Among Natural Populations. The University of Chicago Press, Chicago, 1978, 590 p.

WU, K. S.; TANKSLEY, S. D. Abundance, polymorphism and genetic mapping of microsatellites in rice. Molecular and General Genetics, v. 241, p. 225-235, 1993.

WYMAN, A.; WHITE, R. A highly polymorphic locus in human DNA. Proceedings of the National Academy of Sciences USA, v. 77, p. 6754-6758, 1980.

YAZBECK, G. M.; KALAPOTHAKIS, E. Isolation and characterization of microsatellite DNA in the piracema fish Procbilodus lineatus (Characiformes). Genetics and Molecular Research, v. 6, p. 1026-1034, 2007.

ZAGANINI, R. L.; HASHIMOTO, D.T.; PEREIRA, L. H. G.; OLIVEIRA, C.; MENDONÇA, F. F.; FORESTI, F.; PORTO-FORESTI, F. Isolation and characterization of microsatellite loci in the Neotropical fish Astyanax altiparanae (Teleostei: Characiformes) and cross-species amplification. Journal of Genetics, v. 91, p. e24-e27, 2012.

ZALAPA, J. E.; CUEVAS, H.; ZHU, H.; STEFFAN, S.; SENALIK, D.;ZELDIN, E.;McCOWN, B.;HARBUT, R.;SIMON, P. Using next-generation sequencing approaches to isolate simple sequence repeat (SSR) loci in the plant sciences. American Journal of Botany, v. 99, p. 193-208, 2012.

ZAMUDIO, K. R.; ROBERTSON, J. M.; CHAN, L. M.; SAZIMA, I. Population structure in the catfish Trichogenes longipinnis: drift offset by asymmetrical migration in a tiny geographic range.

Biological Journal of the Linnean Society, v.97, p. 259-274, 2009.

ZANIBONI-FILHO, E.; SCHULZ, U. 2003. Migratory fishes of the Uruguay River. In: CAROLSFELD, J.; HARVEY, B.; ROSS, C.; BAER, A. (eds),Migratory fishes of South America: biology, fisheries, and conservation status. World Fisheries Trust/IDRC/World Bank, Victoria, USA, p. 157-194, 2003.

ZANE, L.; BARGELLONI, L.; PATARNELLO, T. Strategies for microsatellite isolation: a review. Molecular Ecology, v. 11, p. 1-16, 2002. 
ZAWADZKI, C. H.; BIRINDELLI, J. L. O.; LIMA, F. C. T. A new armored catfish species of the genus Hypostomus Lacépède, 1803 (Siluriformes: Loricariidae) from the upper rio Xingu basin, Brazil.Neotropical Ichthyology, v. 10, p. 245-253, 2012

ZAWADZKI, C. H.; WEBER, C.; PAVANELLI, C. S.; RENESTO, E. Morphological and biochemical comparison of two allopatrid populations of Hypostomus margaritifer(Regan, 1907) (Osteichthyes, Loricariidae) from the upper Paraná River basin, Brazil. Acta Scientiarum, v. 24, p. 499-505, 2002.

ZAWADZKI, C. H.; RENESTO, E.; PERES, M. D.; PAIVA, S. Allozyme variation among three populations of the armored catfish Hypostomus regani (Ihering, 1905) (Siluriformes, Loricariidae) from the Paraná and Paraguay river basins, Brazil. Genetics and Molecular Biology, v. 31, p. 767-771, 2008.

ZAWADZKI, C. H.; RENESTO, E.; REIS, R. E.; MOURA, M. O.; MATEUS, R. P. Allozyme relationships in hypostomines (Teleostei: Loricariidae) from the Itaipu Reservoir, Upper Rio Paraná basin, Brazil. Genetica, v. 123, p. 271-283, 2005. 